Fall 1927

\title{
1927 Cedrus Yearbook
}

\section{Cedarville College}

Follow this and additional works at: https://digitalcommons.cedarville.edu/yearbooks

Part of the Higher Education Commons, Organizational Communication Commons, and the Public Relations and Advertising Commons

\section{Recommended Citation}

Cedarville College, "1927 Cedrus Yearbook" (1927). Yearbooks. 81.

https://digitalcommons.cedarville.edu/yearbooks/81

This Book is brought to you for free and open access by DigitalCommons@Cedarville, a service of the Centennial Library. It has been accepted for inclusion in Yearbooks by an authorized administrator of DigitalCommons@Cedarville. For more information, please contact digitalcommons@cedarville.edu. 
KI
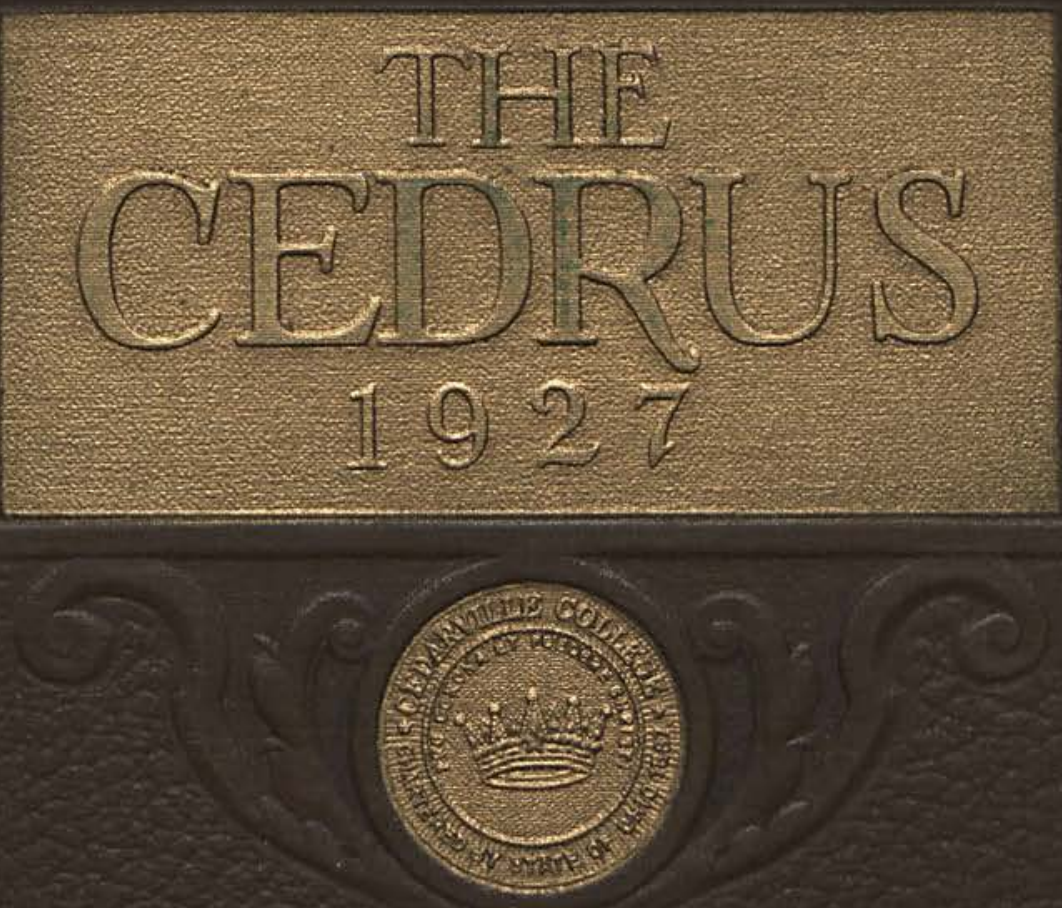


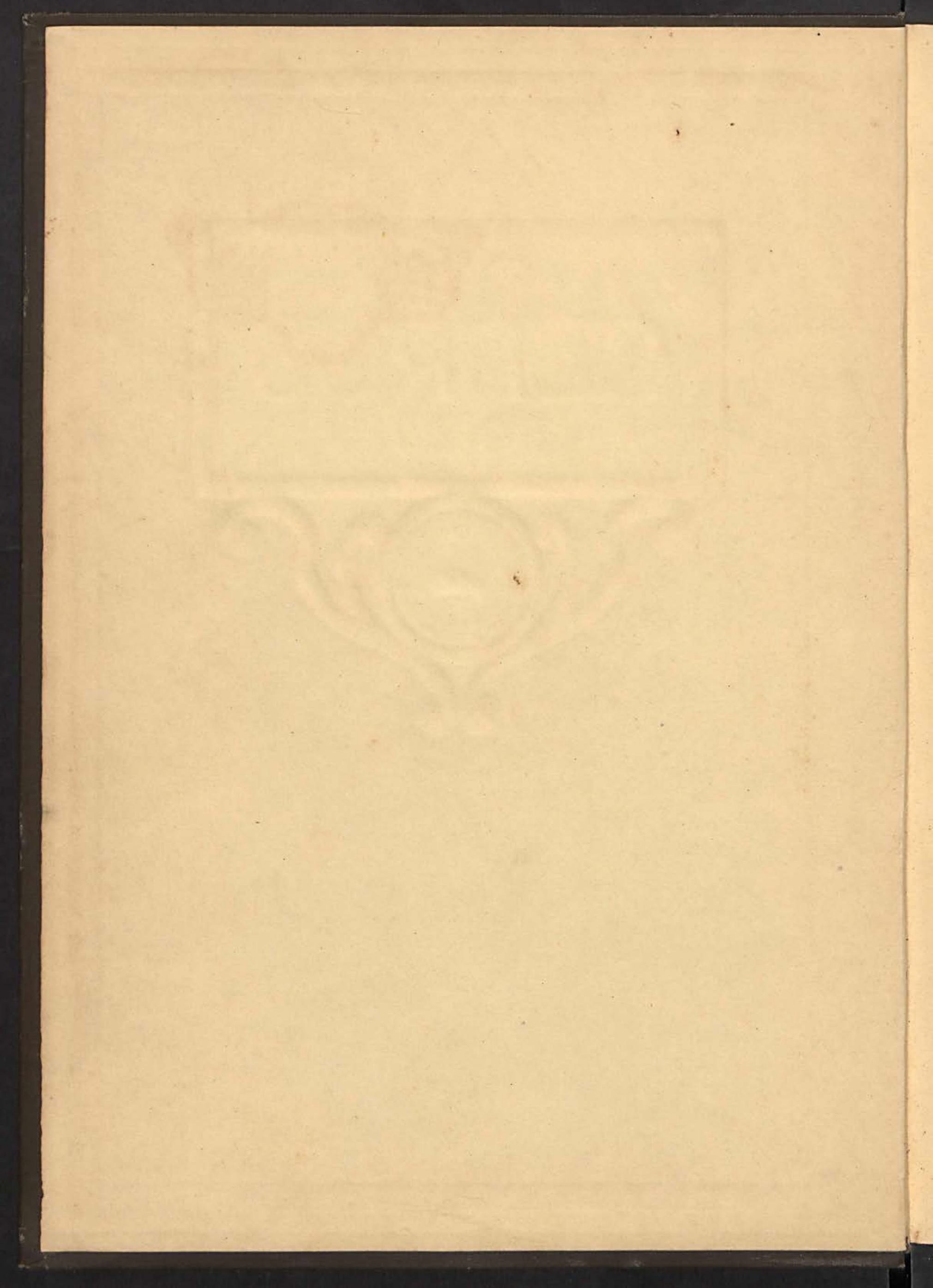




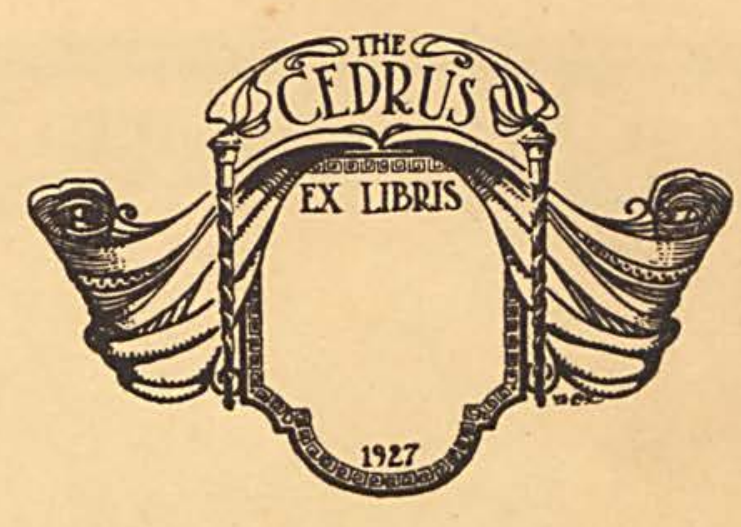

Paul P. Janner. 



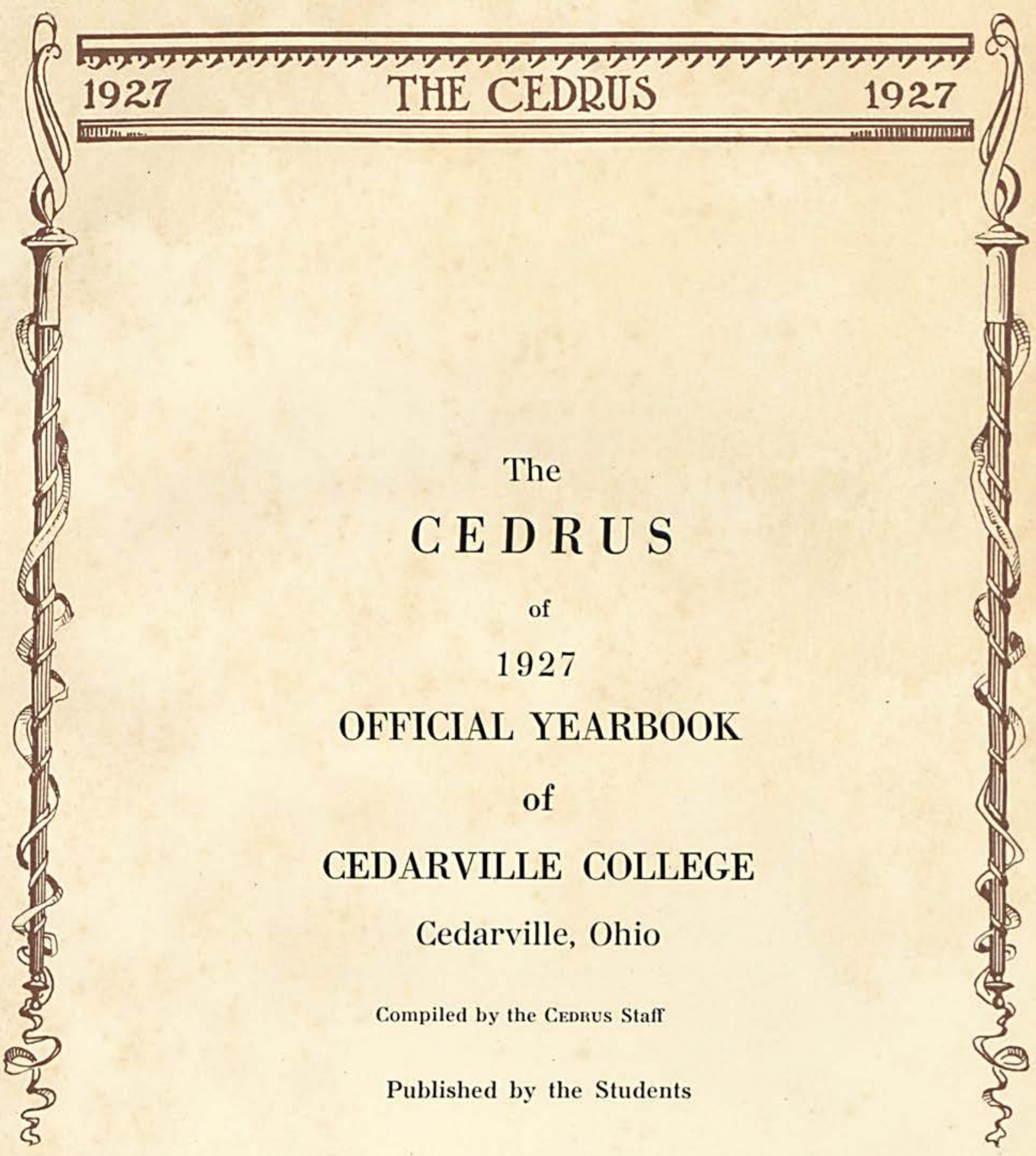




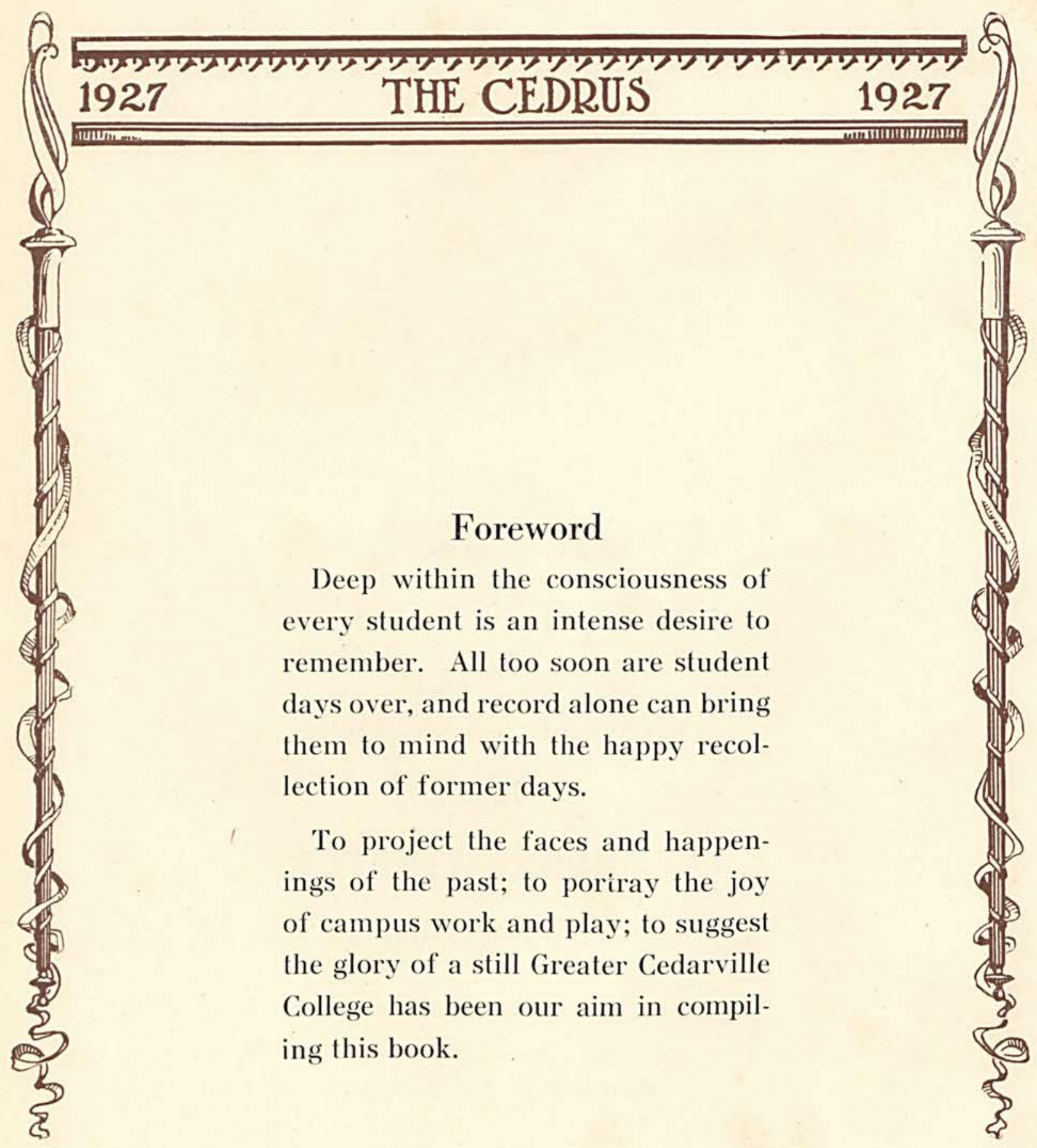




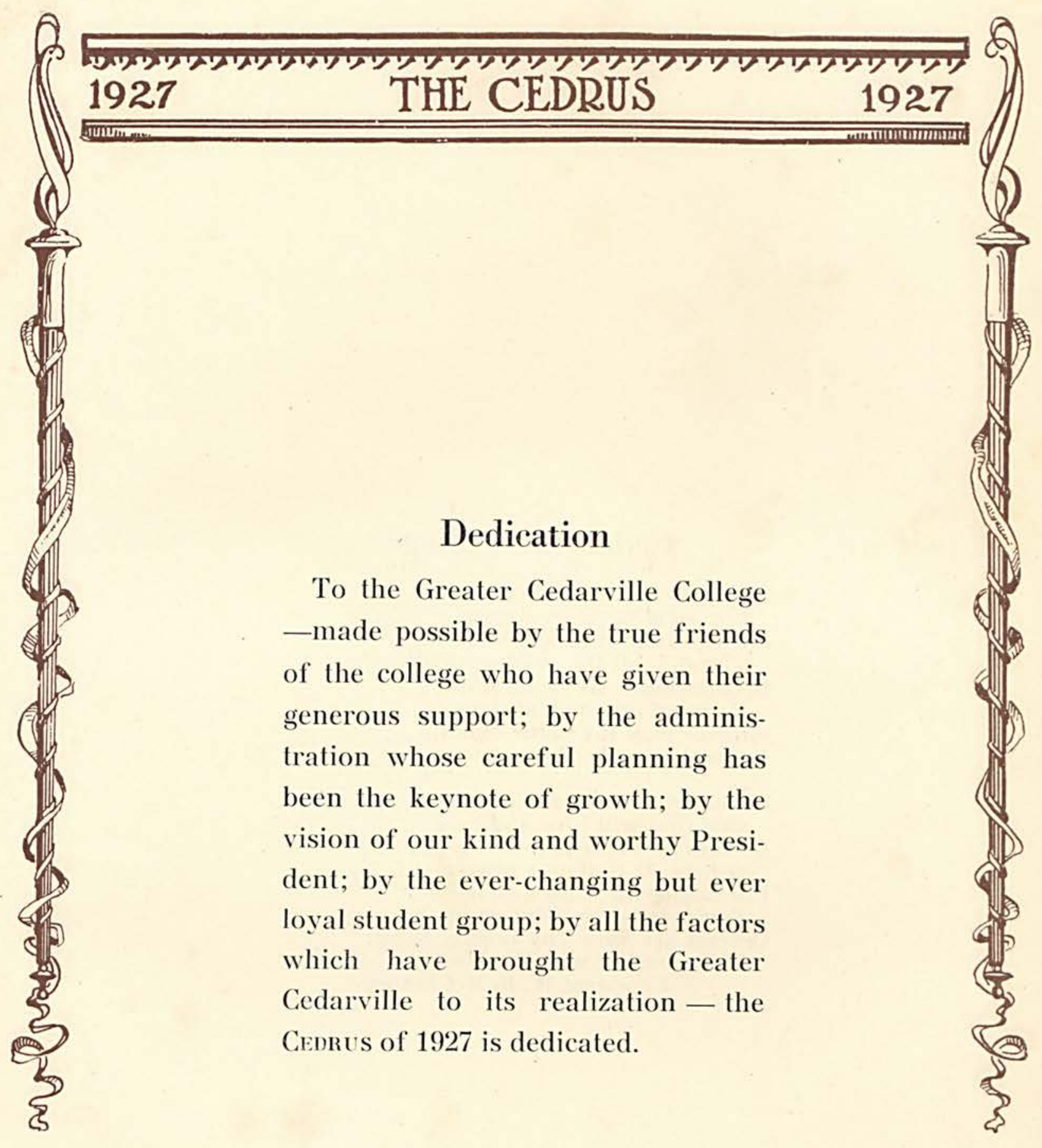




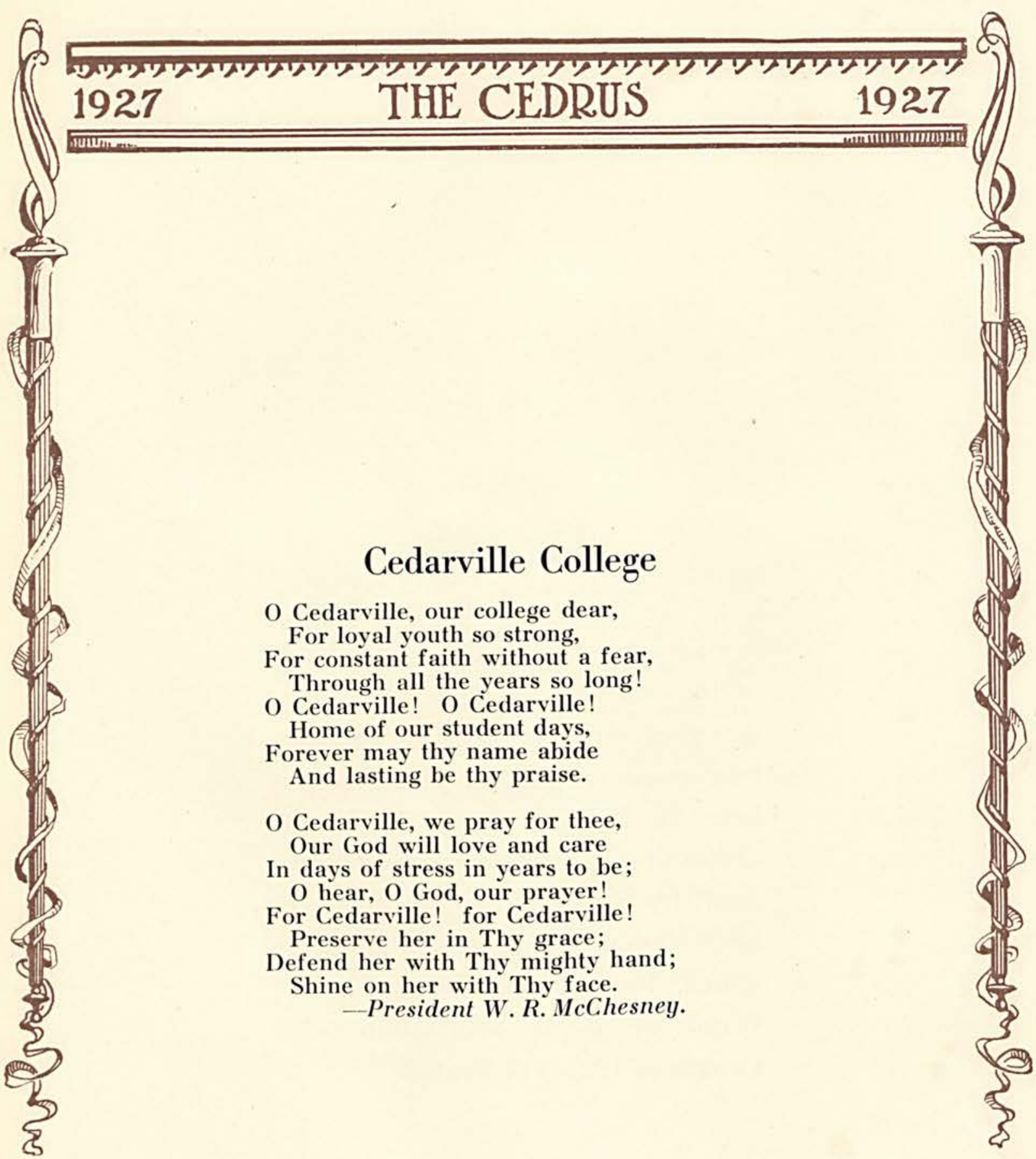




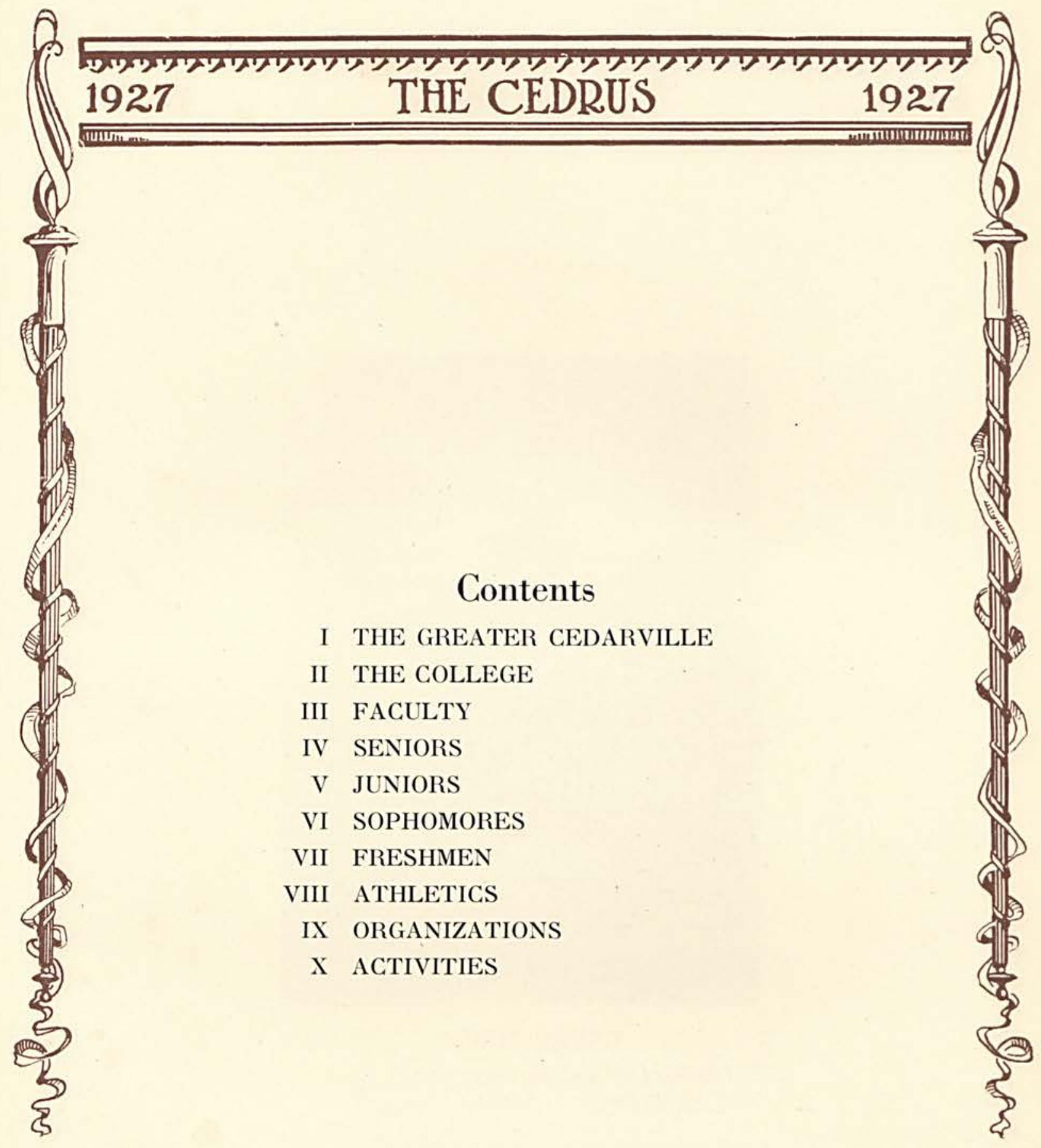




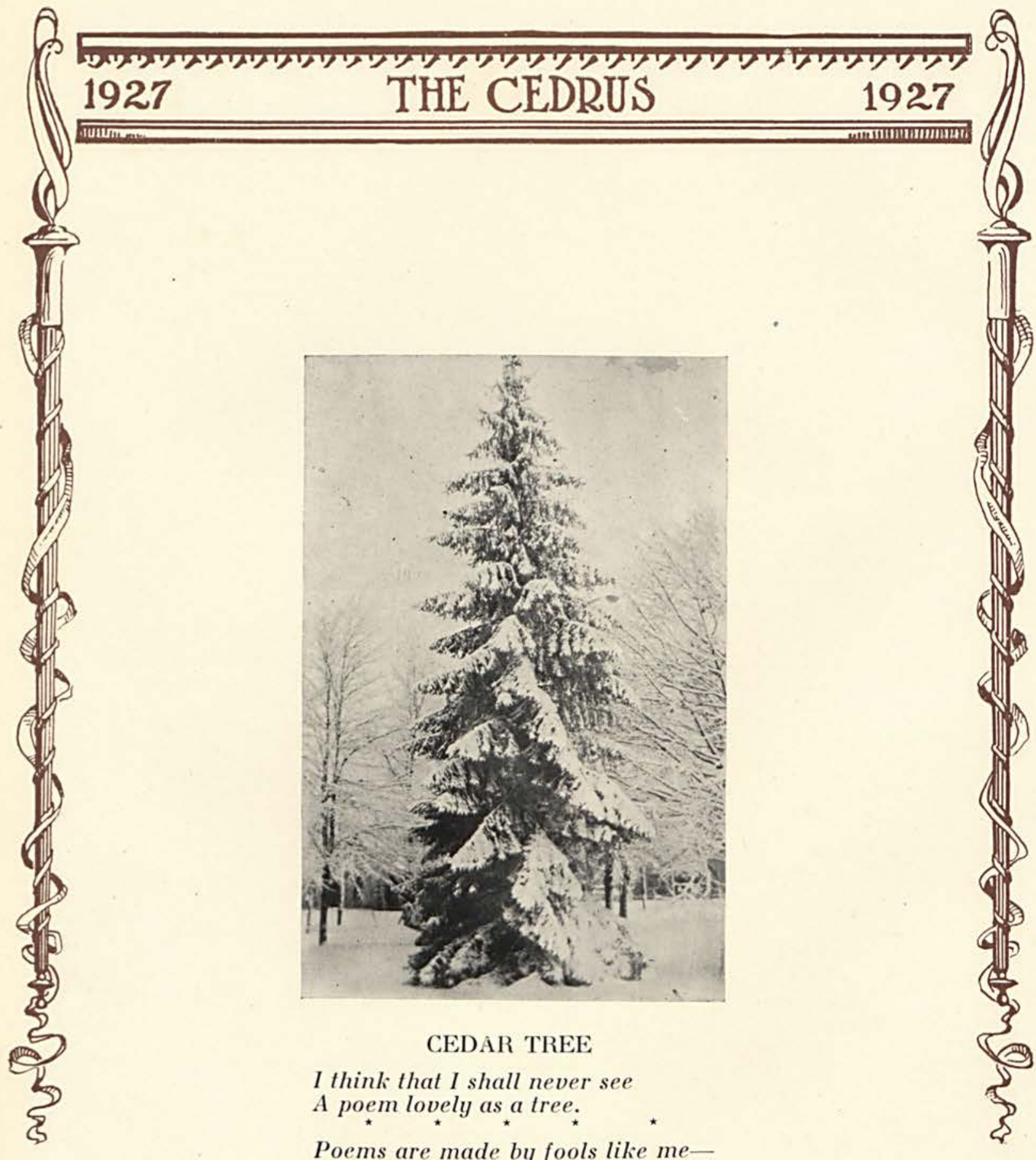

Poems are made by fools like meBut only God can make a tree. -Joyce KiLmer. 


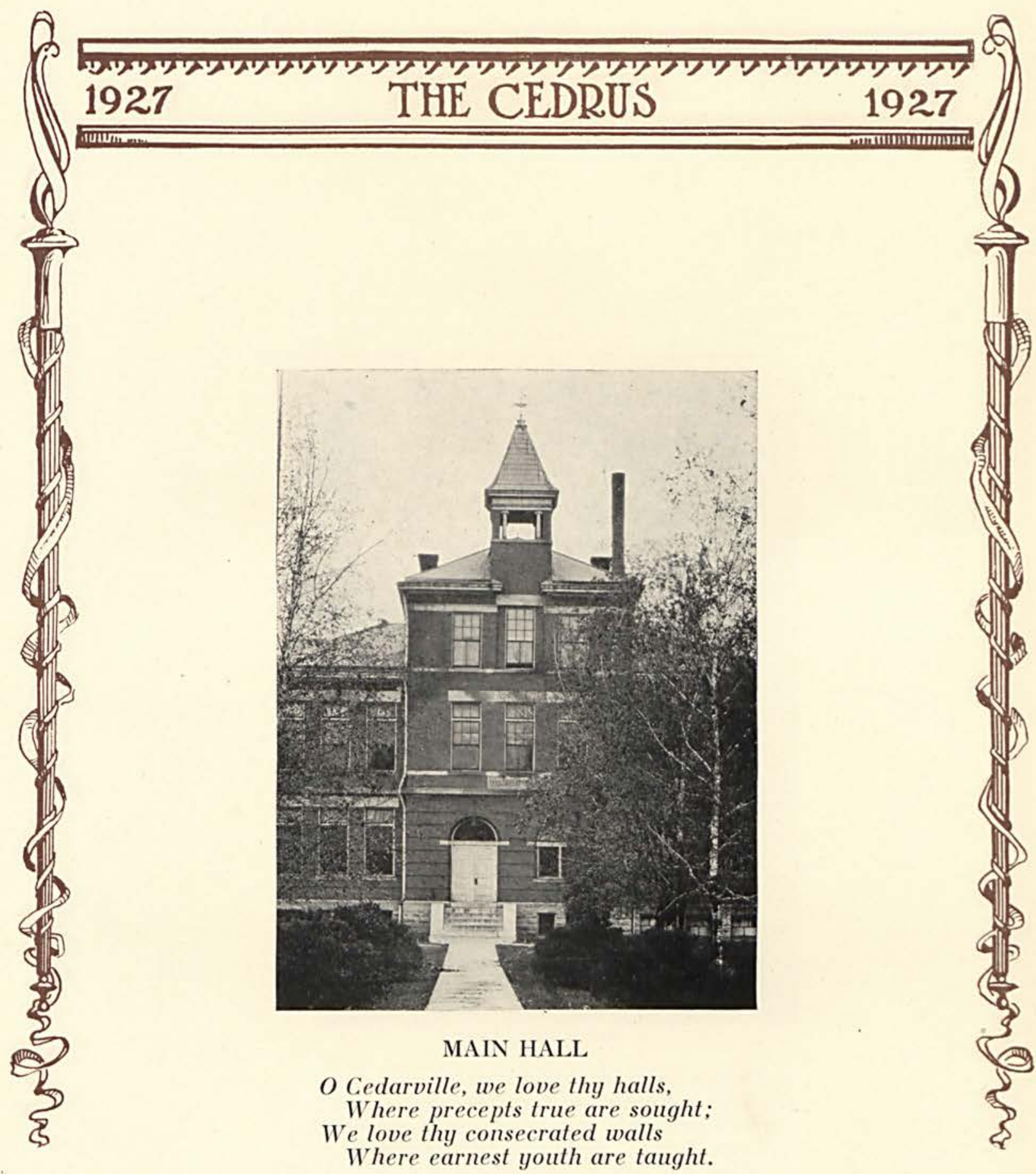

-President W. R. McChesney. 


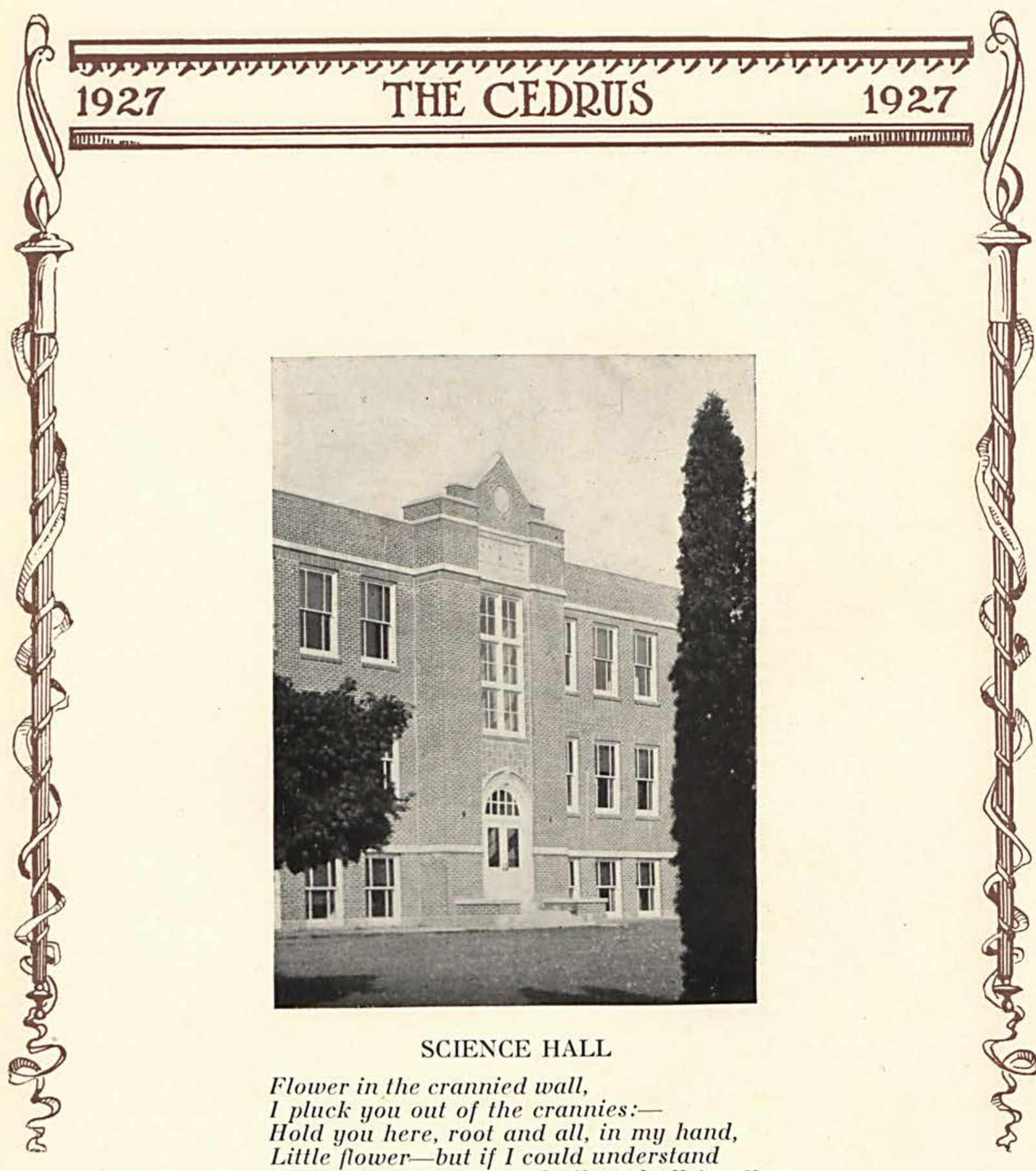

What you are, root and all, and all in all, I should know what God is. 


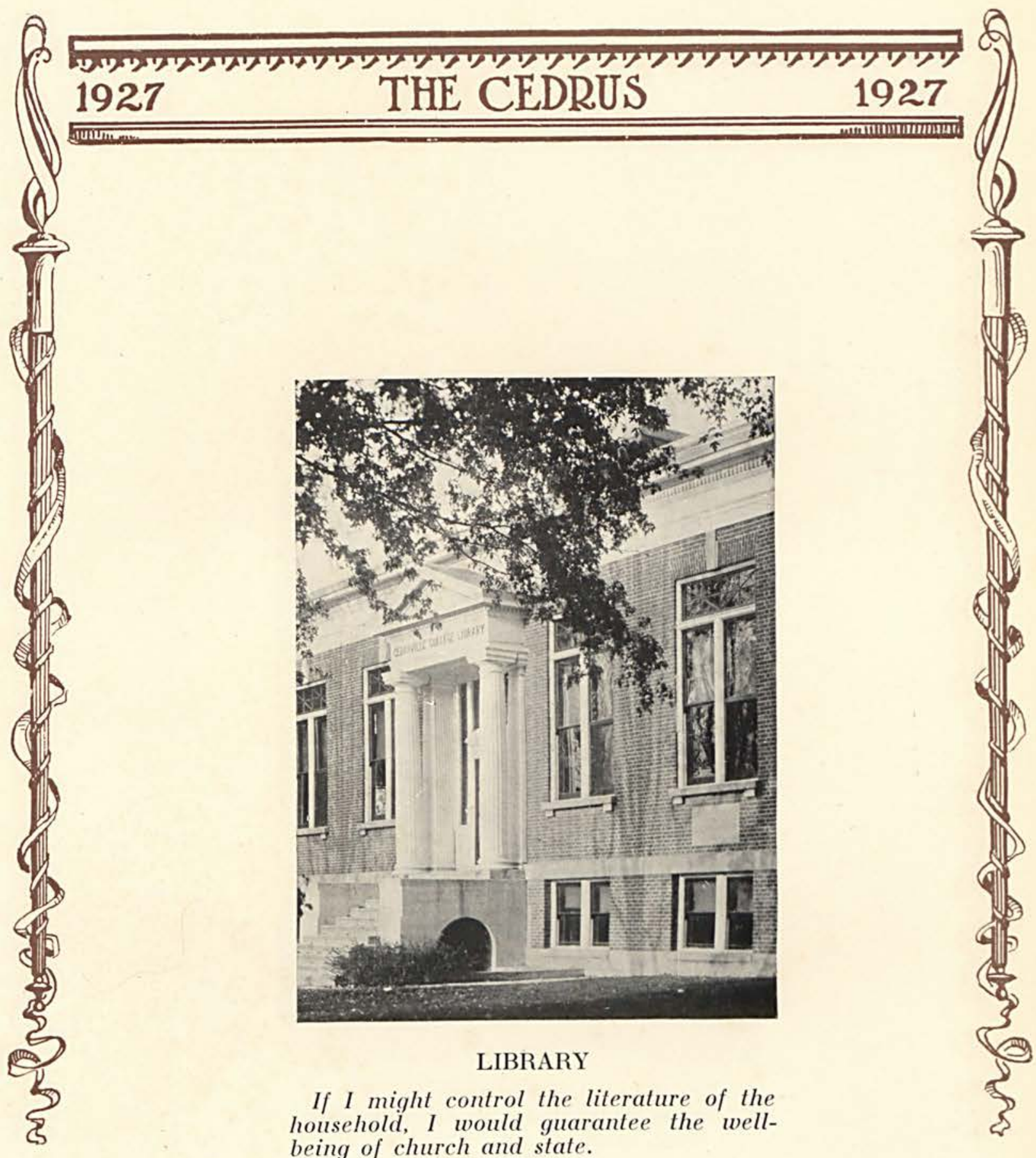
being of church and state. -Bacon. 


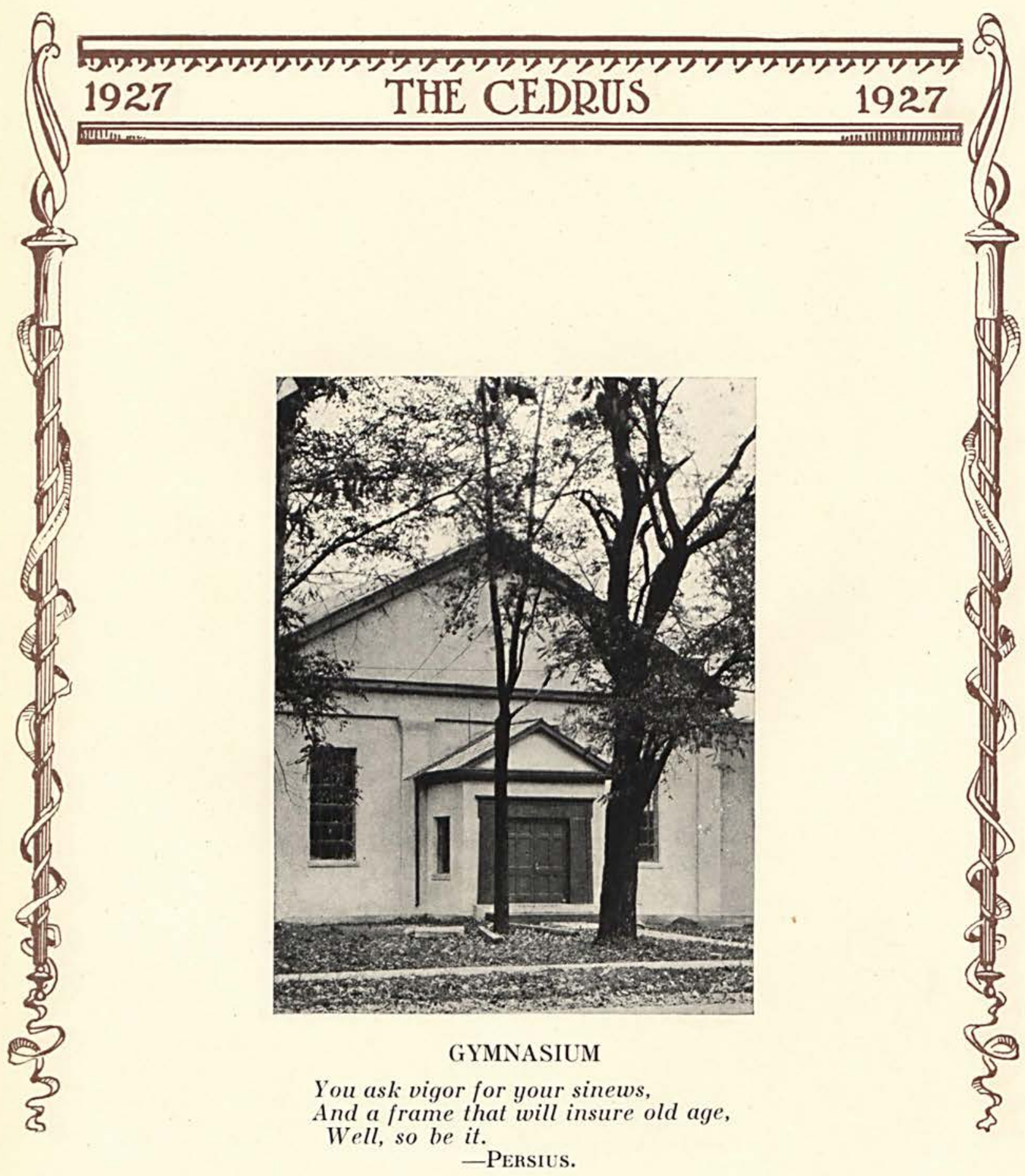




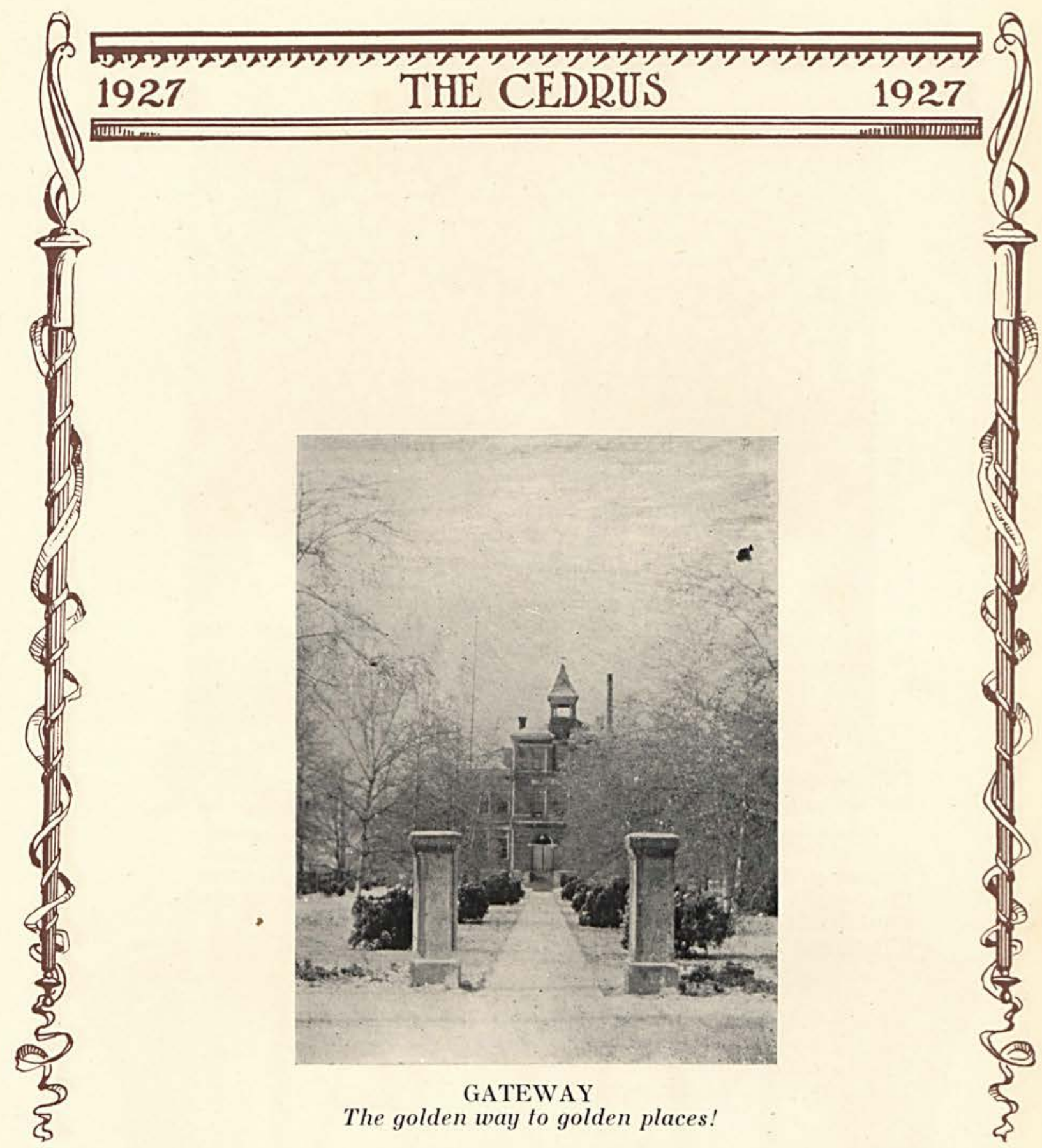




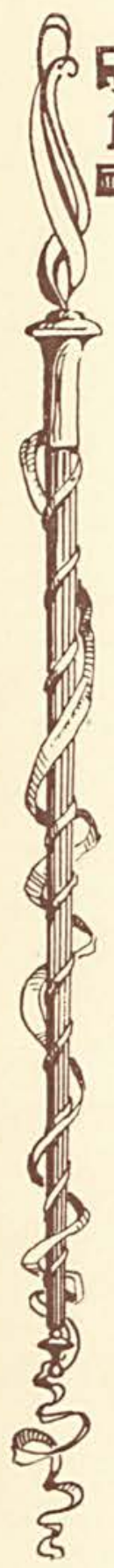

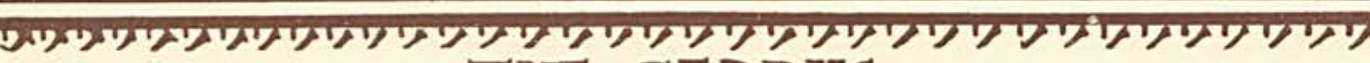
1927

THE CEDRUS

OLD MAIN

I'll love to see the cedars on the campus up at school;

I'il love to drink the water from the pump; it's sweet and cool;

I'll love to walk the board walk to the new brick Science Hall;

But I'll love to walk the corr'dors of Old Main first of all.

I'll love to see a game again in the college's new "gym;"

I'll love to watch the students pass so full of pep and vim;

I'll love to go and read a book and sit hushed in the hall

Of the library. But Old Main, I'll love it last of all.

I'll love to dine again in the basement where we eat;

I'll love to feel the campus grass come springing 'neath my feet;

I'll love to watch the college men come forth with college ball,

But still I'll turn toward Old Main, the very best of all.

Yes, when I am old and graying and mem'ries are my pleasures I'll regard each sep'rate saying as among my choicest treasures;

I'll think of ev'ry happ'ning, ev'ry nod, each beck and call,

But I think I'll think of Old Main Hall the oftenest of all.

'Tis the first of all the colleges, 'tis the last one, too, we say.

'Tis the best one in the country, 'tis the college of today.

'Tis the college, first, and last, and best,

The only C. C. in the west.

$$
\text { HAIL OLD MAIN! }
$$




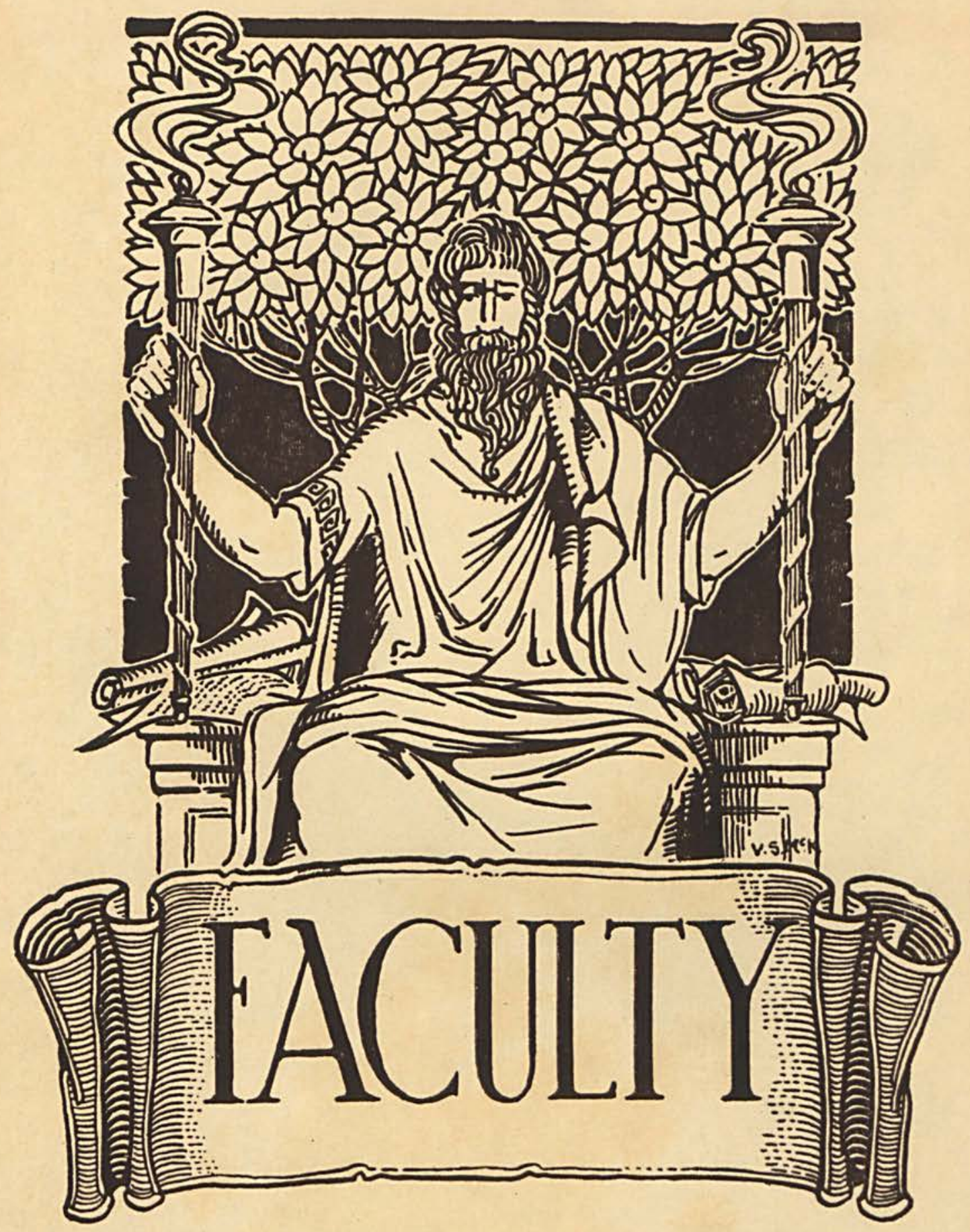





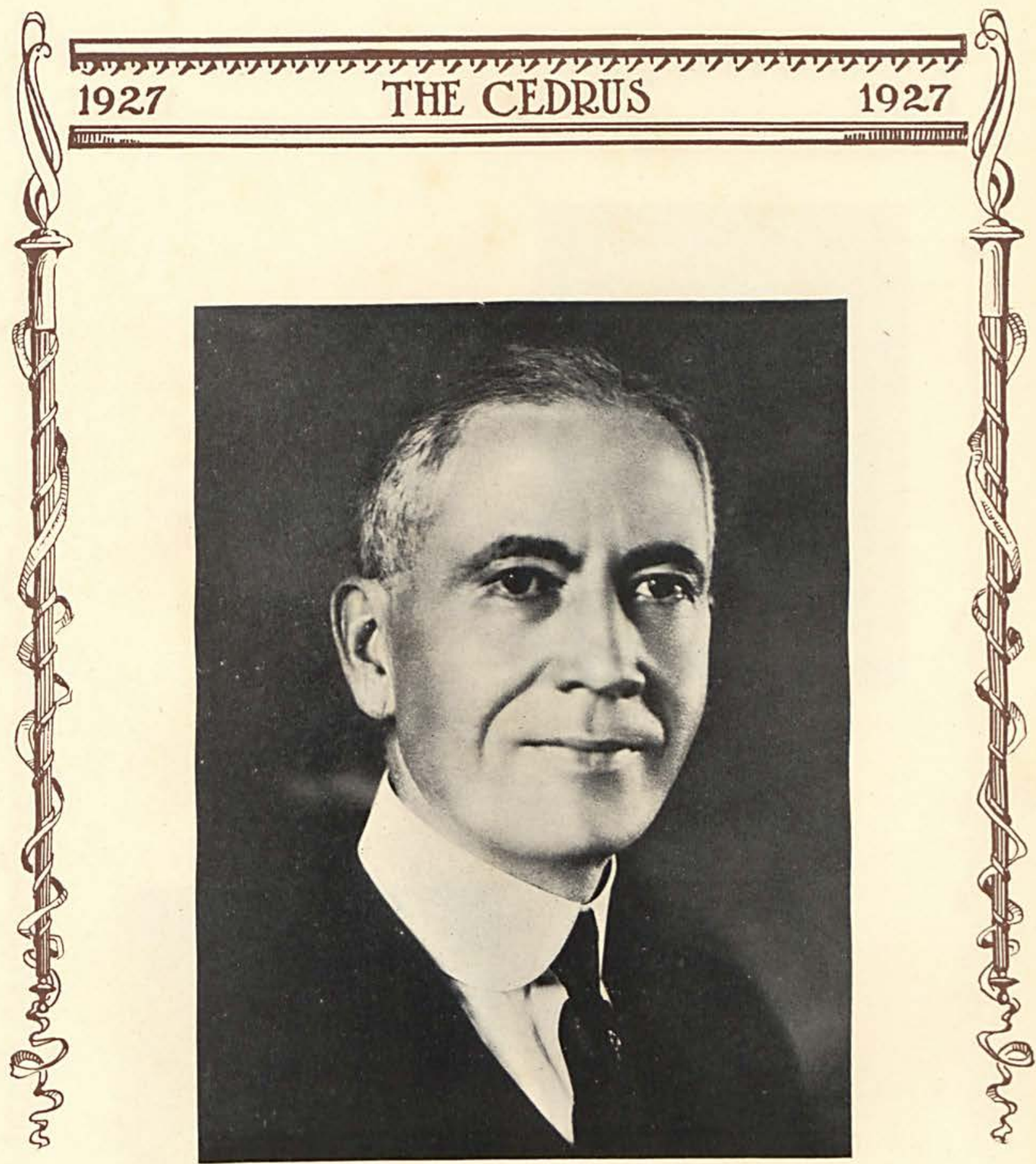

W. RENWICK McCHESNEY, Ph.D., D. D.

President 


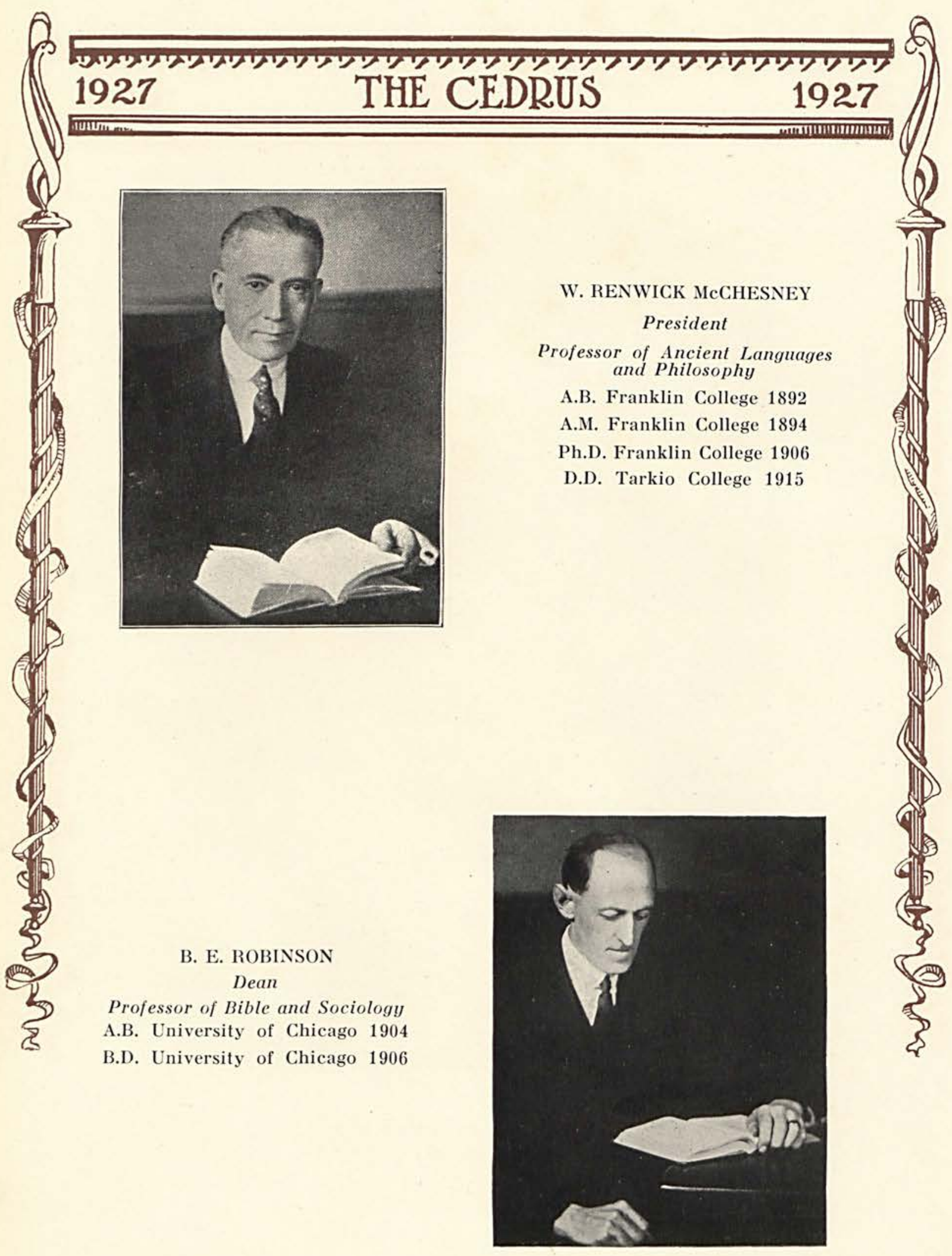




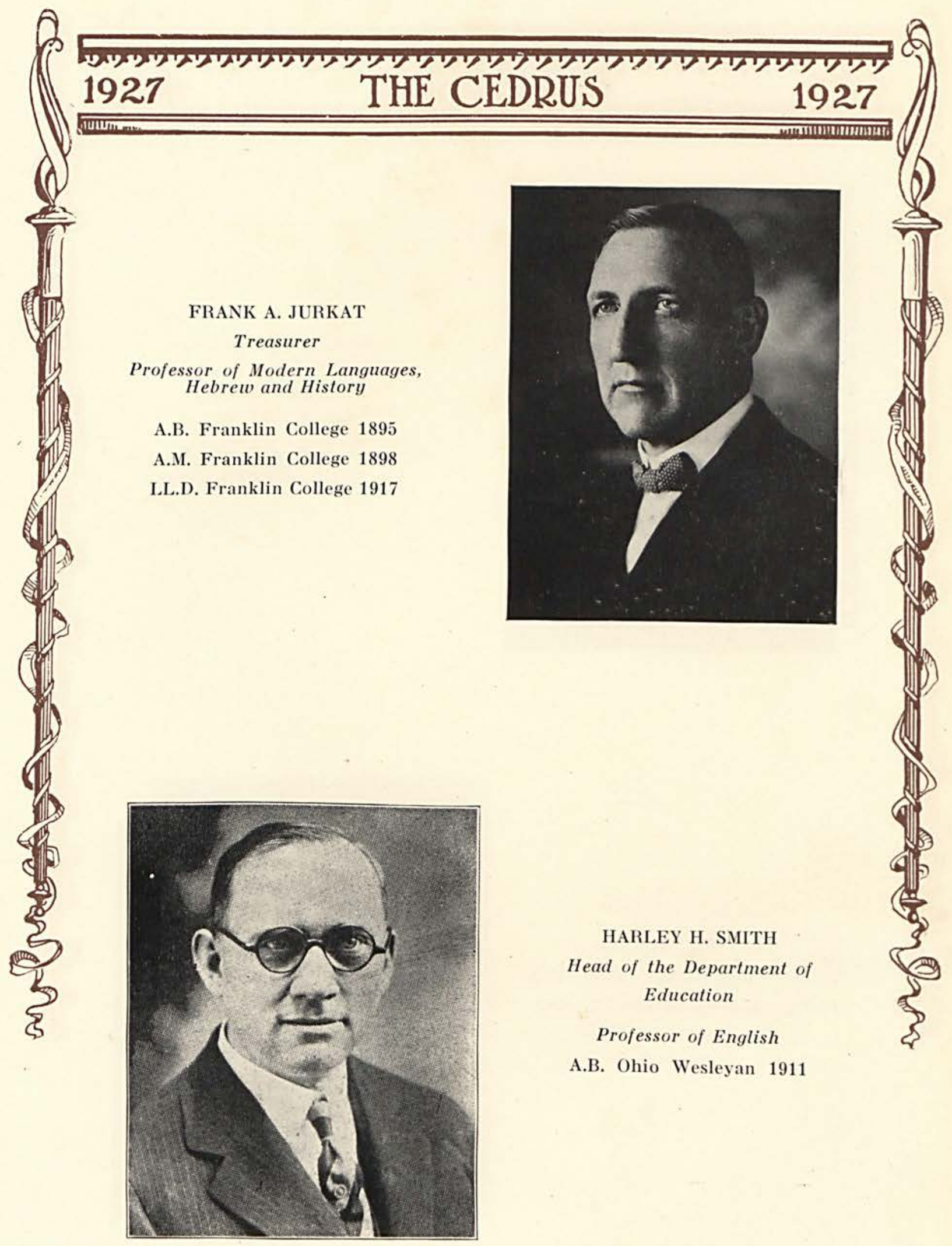




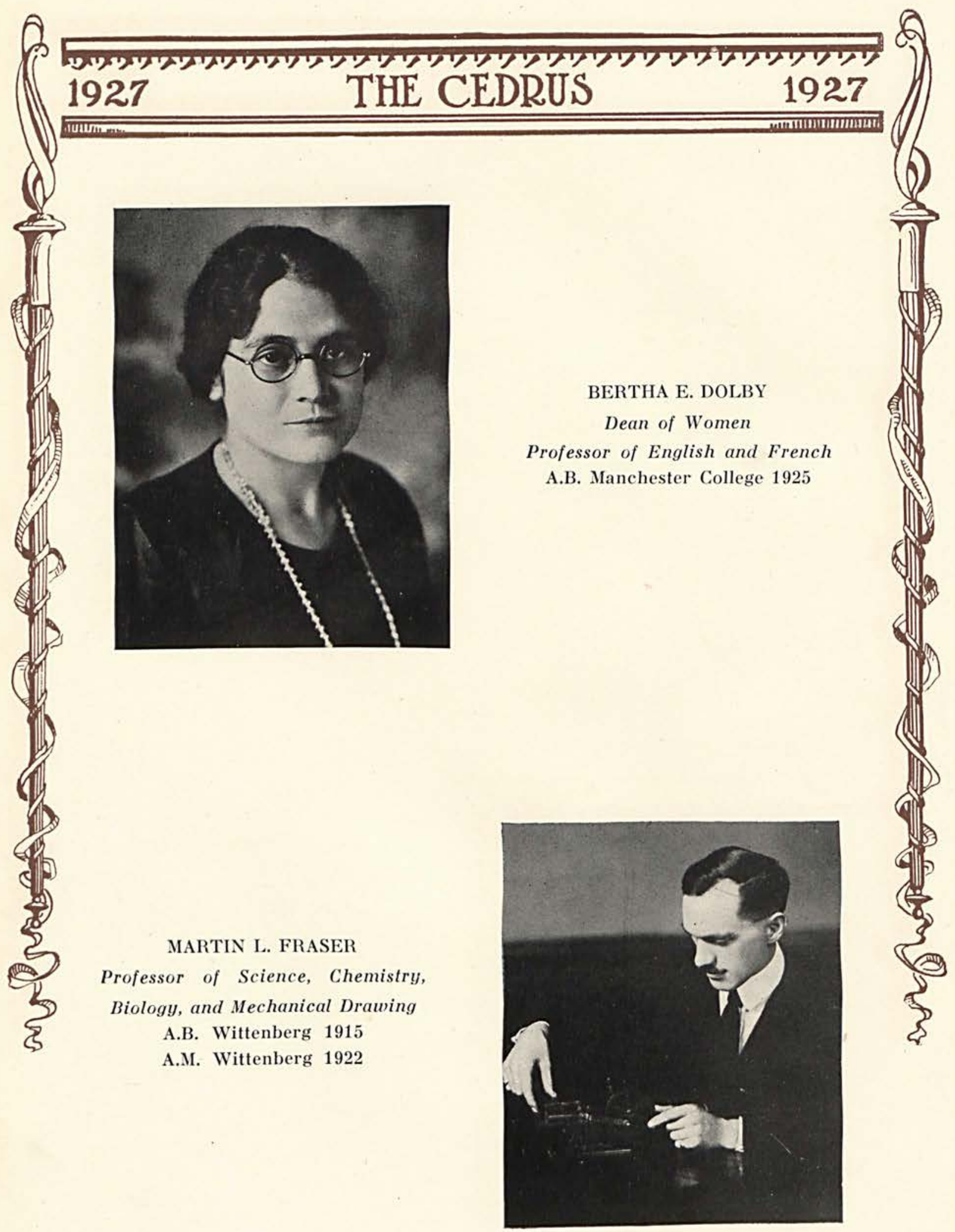




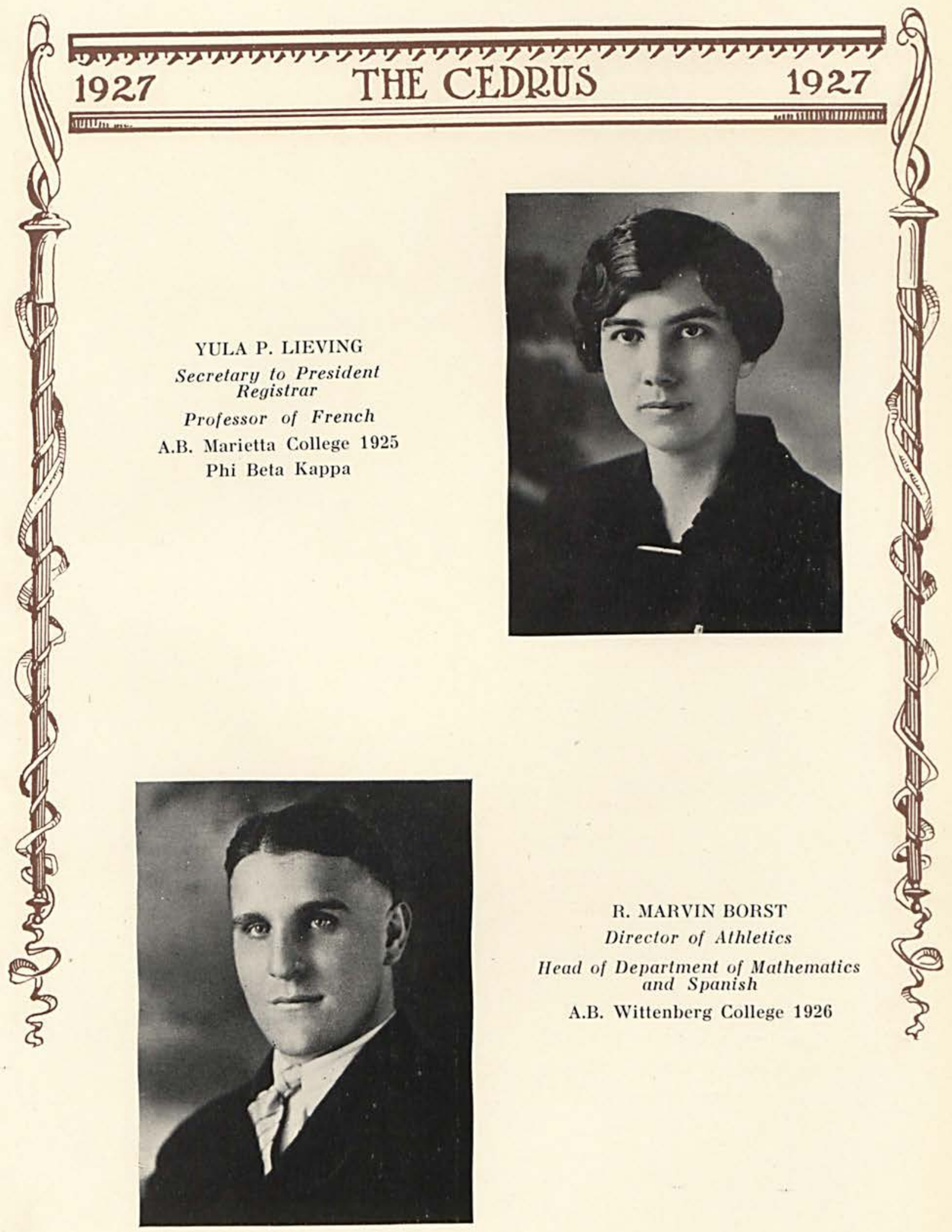




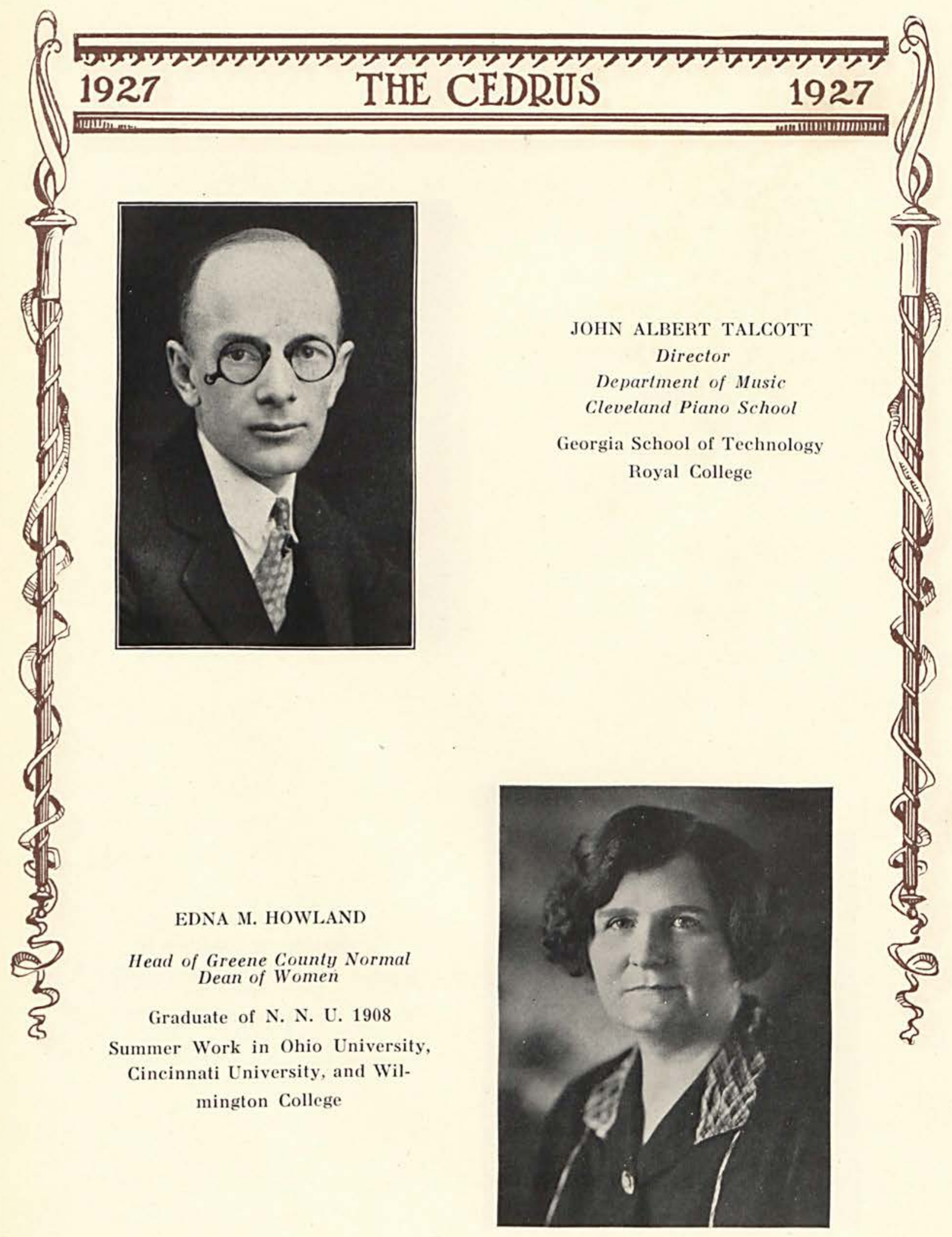




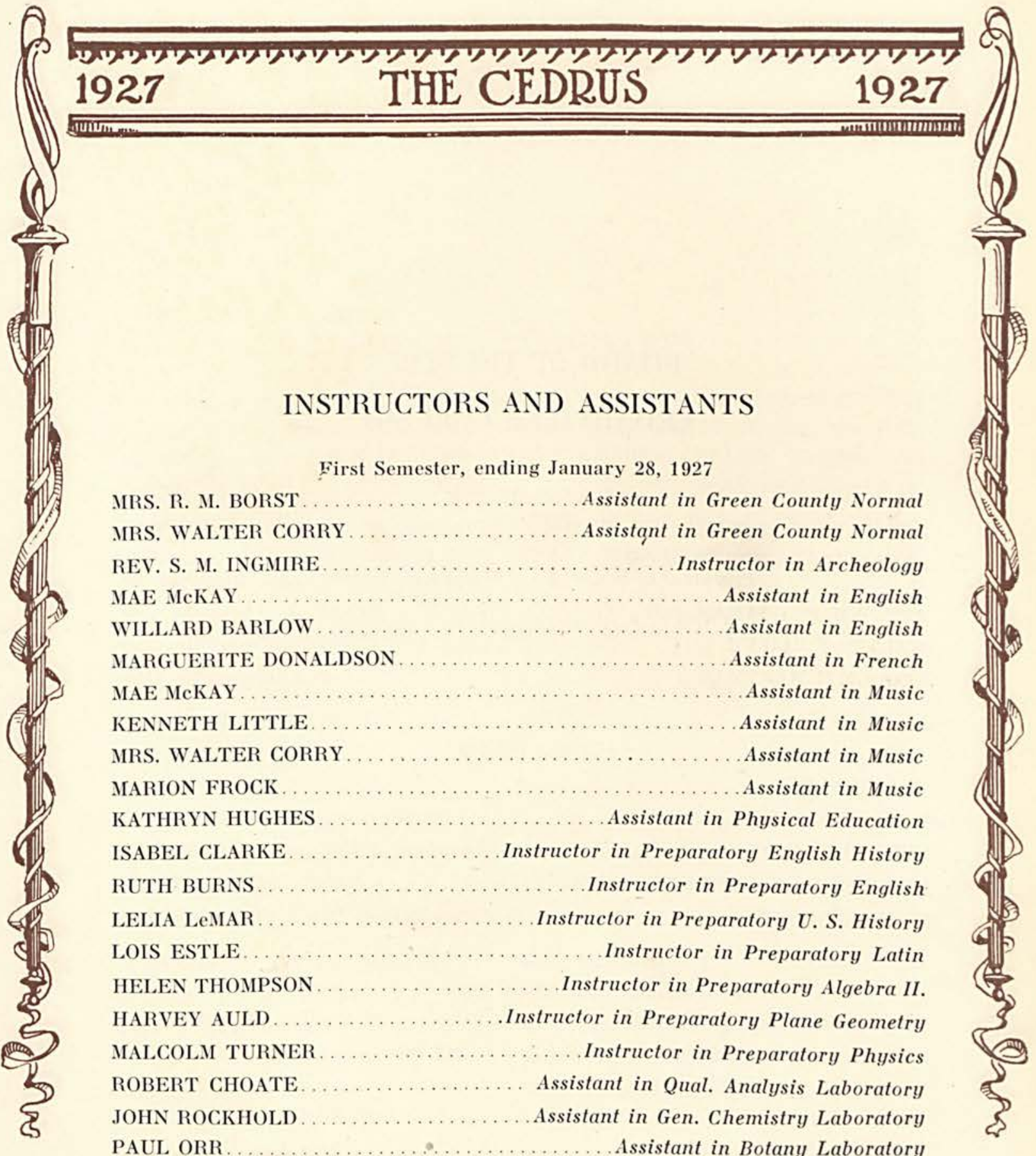




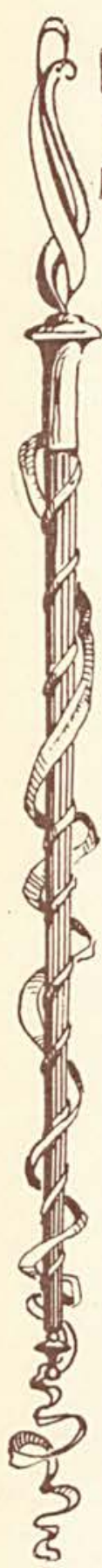

1927 THE CEDRUS 1927

जIIIIIIIIIIIIIIIII)

\section{BOARD OF TRUSTEES}

\section{CEDARVILLE COLLEGE}

\section{CLASS OF 1926}

REV. W. R. McCHESNEY, D.D., Ph.D. ..... President of College, Cedarville, Ohio REV. J. ALVIN ORR, D.D., '97

President of Board, No. 2 Watson Entrance, N. S., Pittsburgh, Pa. REV. WM. R. GRAHAM, D.D., '05

Brown St., LaFayette, Ind.

WALTER C. ILIFFE

Cedarville, Ohio

GEORGE H. HARTMAN

Cedarville, Ohio

\section{CLASS OF 1927}

WM. CONLEY

Cedarville, Ohio

WM. R. COLLINS, A.B., '18 .

1928 Coventry Rd., Columbus, Ohio PROF. F. A. JURKAT, LL. D. Treasurer of College, Cedarville, Ohio REV. HOMER B. HENDERSON, D.D., '02 .

Grove City, Pa. M. I. MARSH, M.D.

Vice President of Board, Cedarville, Ohio

CLASS OF 1928

REV. HOMER McMILLAN, D.D., '97 . 101 Marietta St., Atlanta, Ga. REV. DAVID MCKINNEY, D.D., LL.D., 218 Woolper Ave., Cincinnati, Ohio REV. W. P. HARRIMAN, D.D.

Cedarville, Ohio FRANK P. HASTINGS

East Market St., Xenia, Ohio

S. C. WRIGHT, A.B., '03. Secretary, Xenia, Ohio

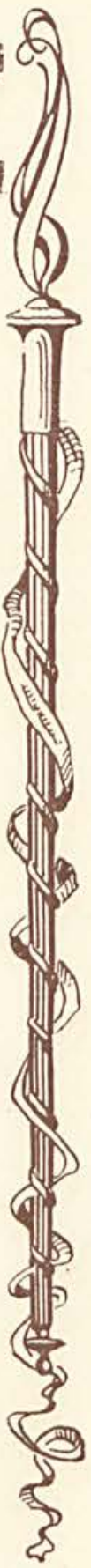




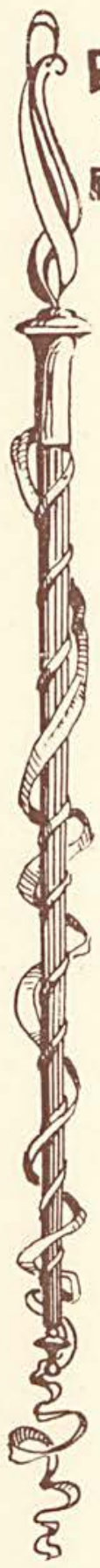

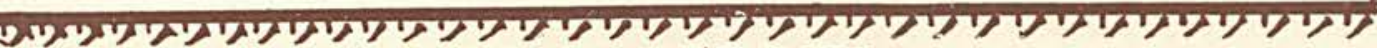
1927 THE CEDRUS 1927

\section{STANDING COMMITTEES}

Executive

McCHESNEY, HARTMAN, MARSH, COLLINS, HARRIMAN

Finance HASTINGS, McKINNEY, CONLEY, HARTMAN, ORR, GRAHAM

Instruction McMILLAN, McCHESNEY, MARSH, COLLINS, HENDERSON Auditing ILIFFE, HASTINGS, HARTMAN Investment WRIGHT, JURKAT, McKINNEY, HASTINGS Property CONLEY, ILIFFE, JURKAT, WRIGHT, McMILLAN, GRAHAM

\section{LOCAL ADVISORY BOARD}

JAMES H. CRESWELL

R. R. No, 3, Cedarville, Ohio REV. JOHN P. WHITE, D.D. Xenia, Ohio N. L. RAMSEY Cedarville, Ohio

\section{WOMEN'S ADVISORY BOARD}

MRS. W. R. MeCHESNEY President MRS. S. T. Baker Secretary-Treasurer

MISS MARY B. ERVIN, A.B., '02 MRS. JOHN W. JOHNSON MRS. W. H. BARBER MRS. E. C. OGLESBEE MRS. G. H. CRESWELL MRS. S. C. WRIGHT MRS. M. L. FRASER MRS. B. E. ROBISON

MRS. CLAYTON MCMILLAN

MRS. FRED TOWNSLEY

MRS. WALTER ILIFFE

MRS. JAY AULD

MRS. HARRY TOWNSLEY

MRS. W. P. HARRIMAN 


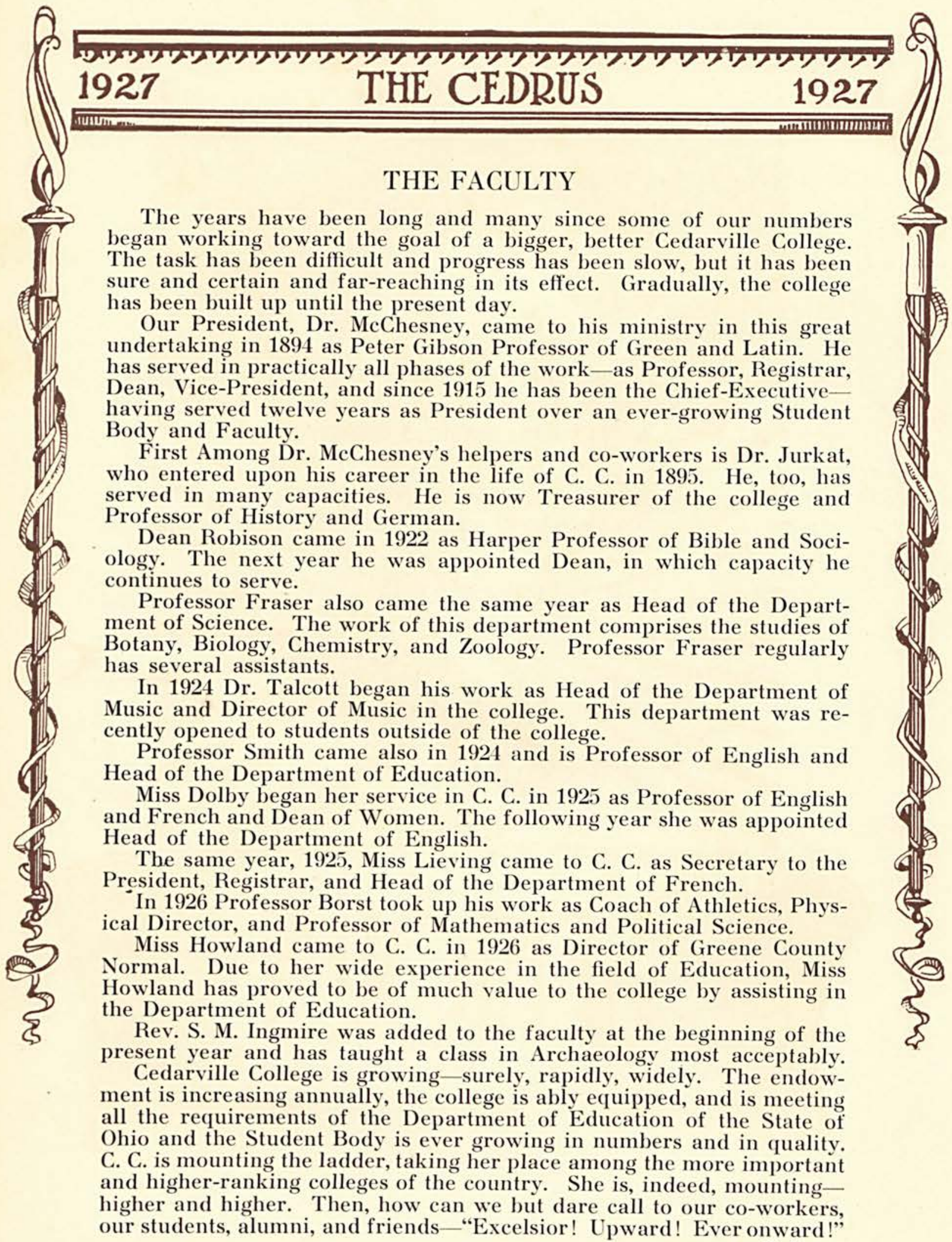
-Y. L. 


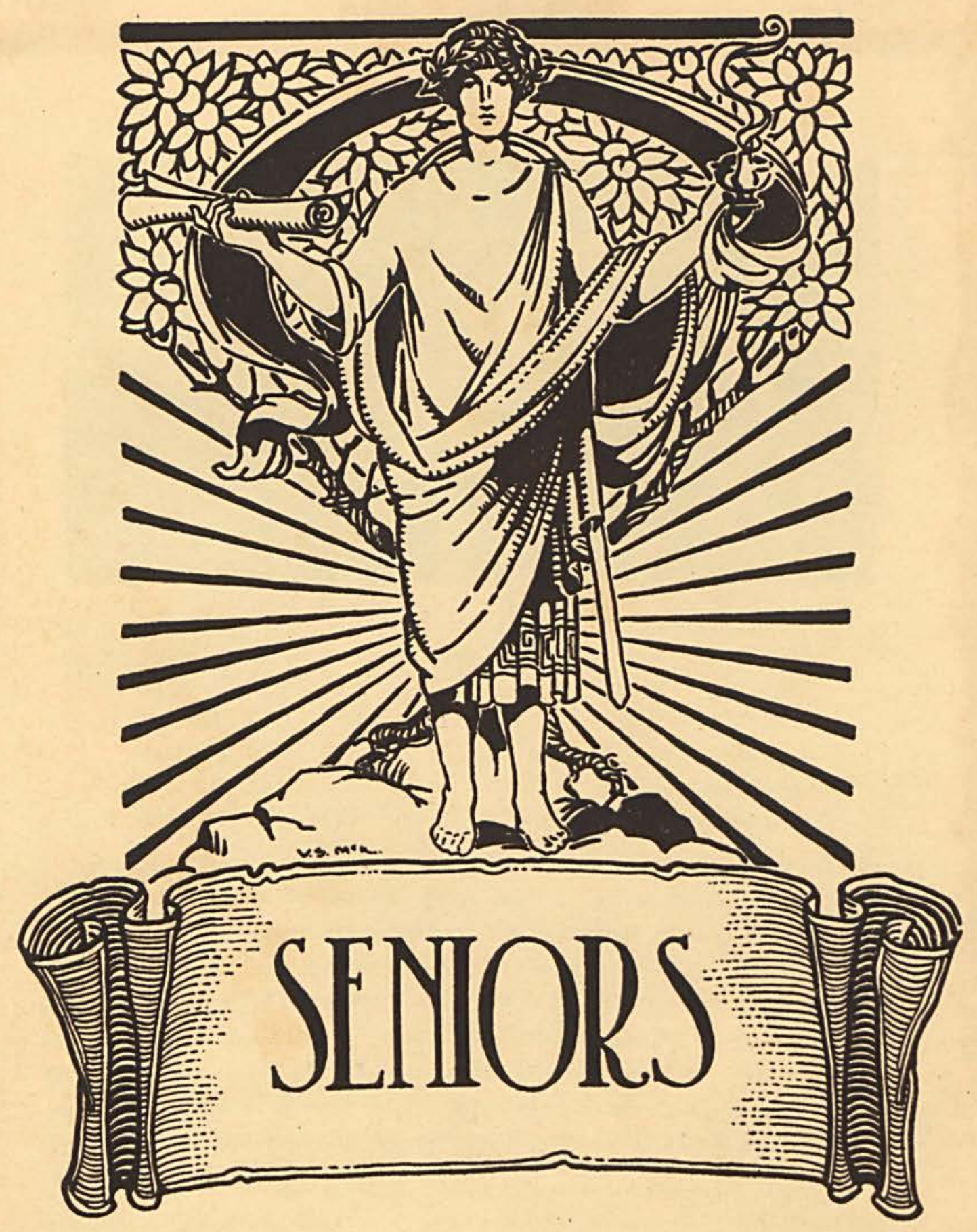





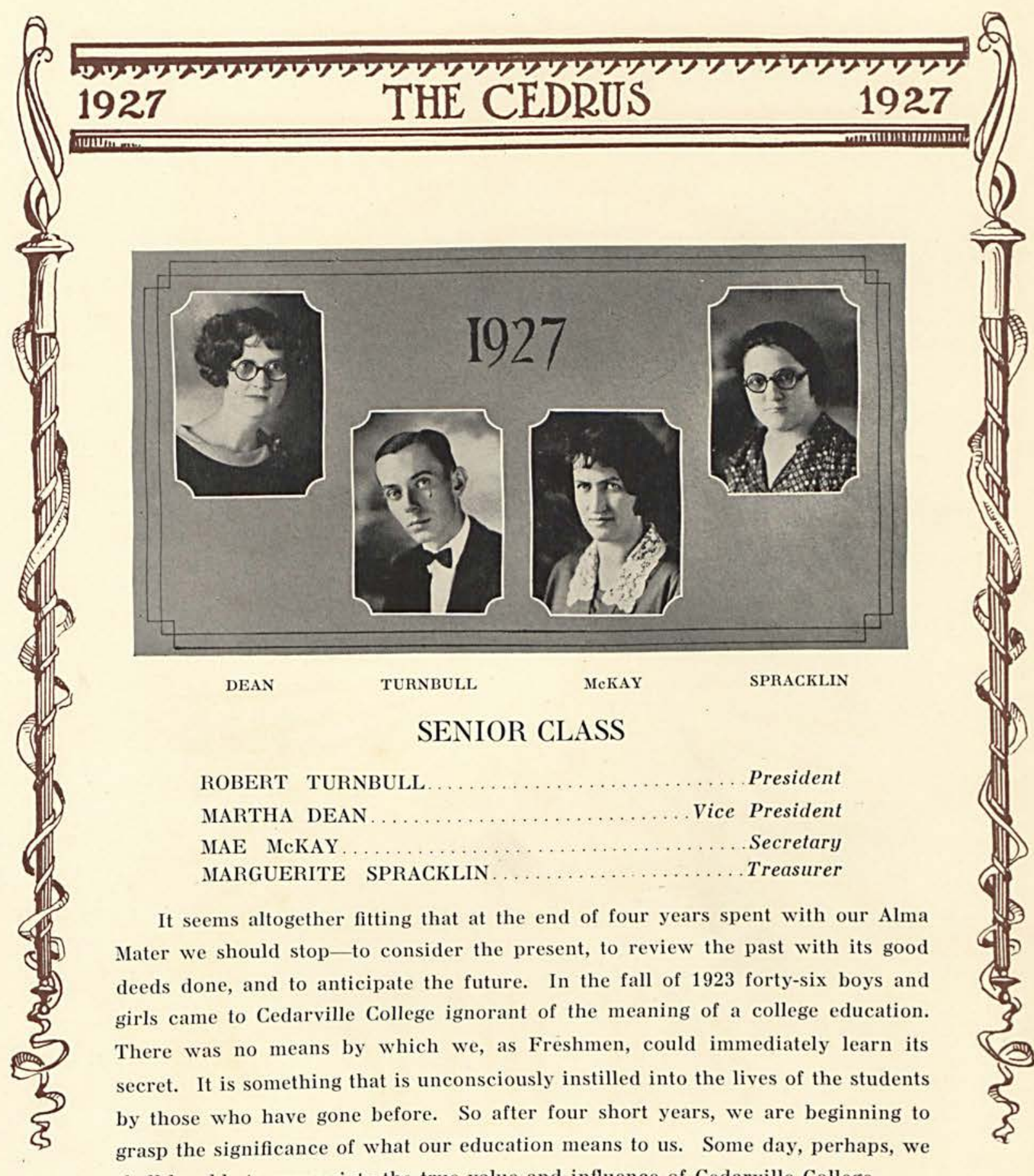
shall be able to appreciate the true value and influence of Cedarville College.

The Class of 1927 has given of its best to further all lines of activity. It has done all in its power to advance a bigger and better Cedarville. Upon graduation it will not forget the happy days of work and play, but will strive to make real the vision of a still greater Cedarville. 


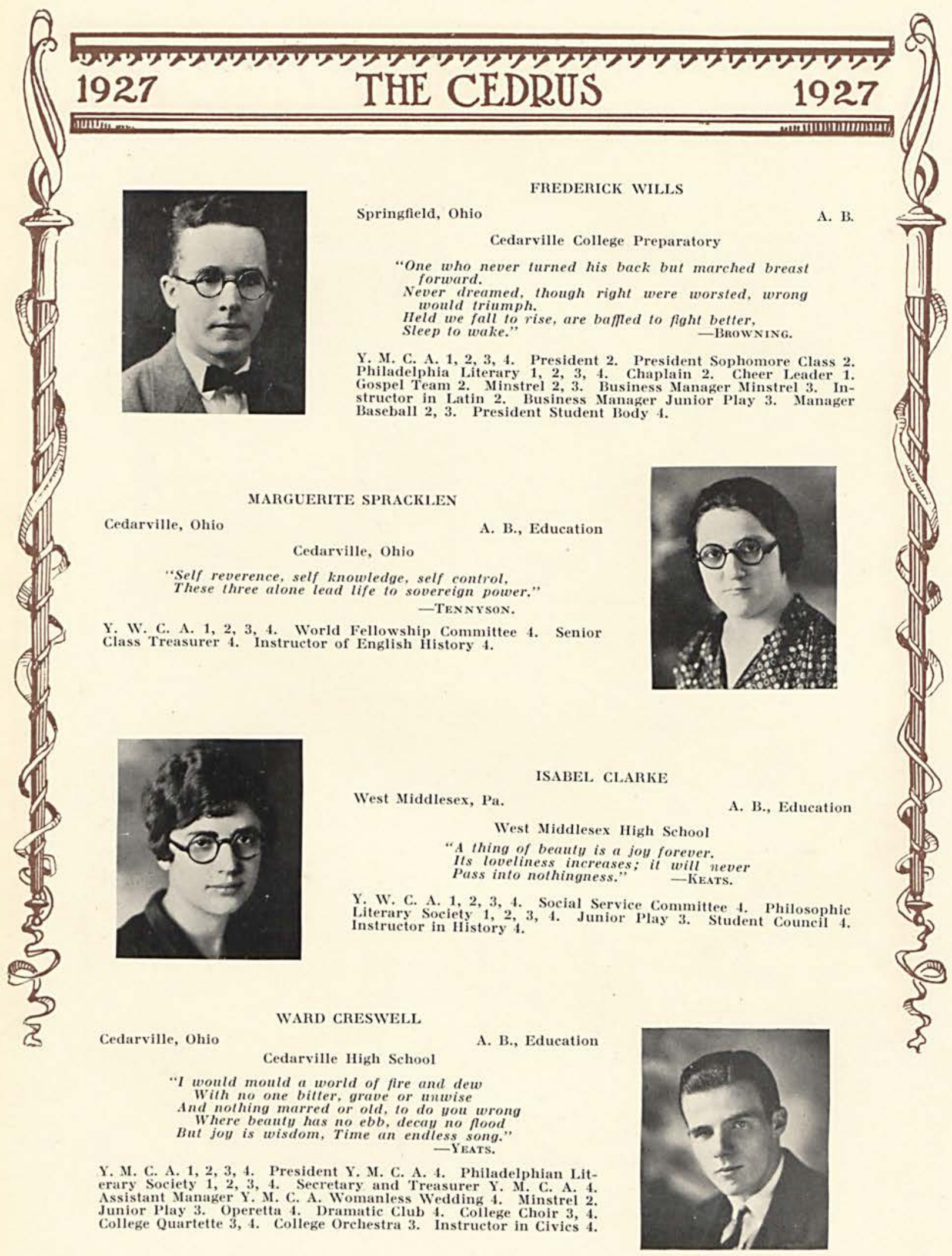




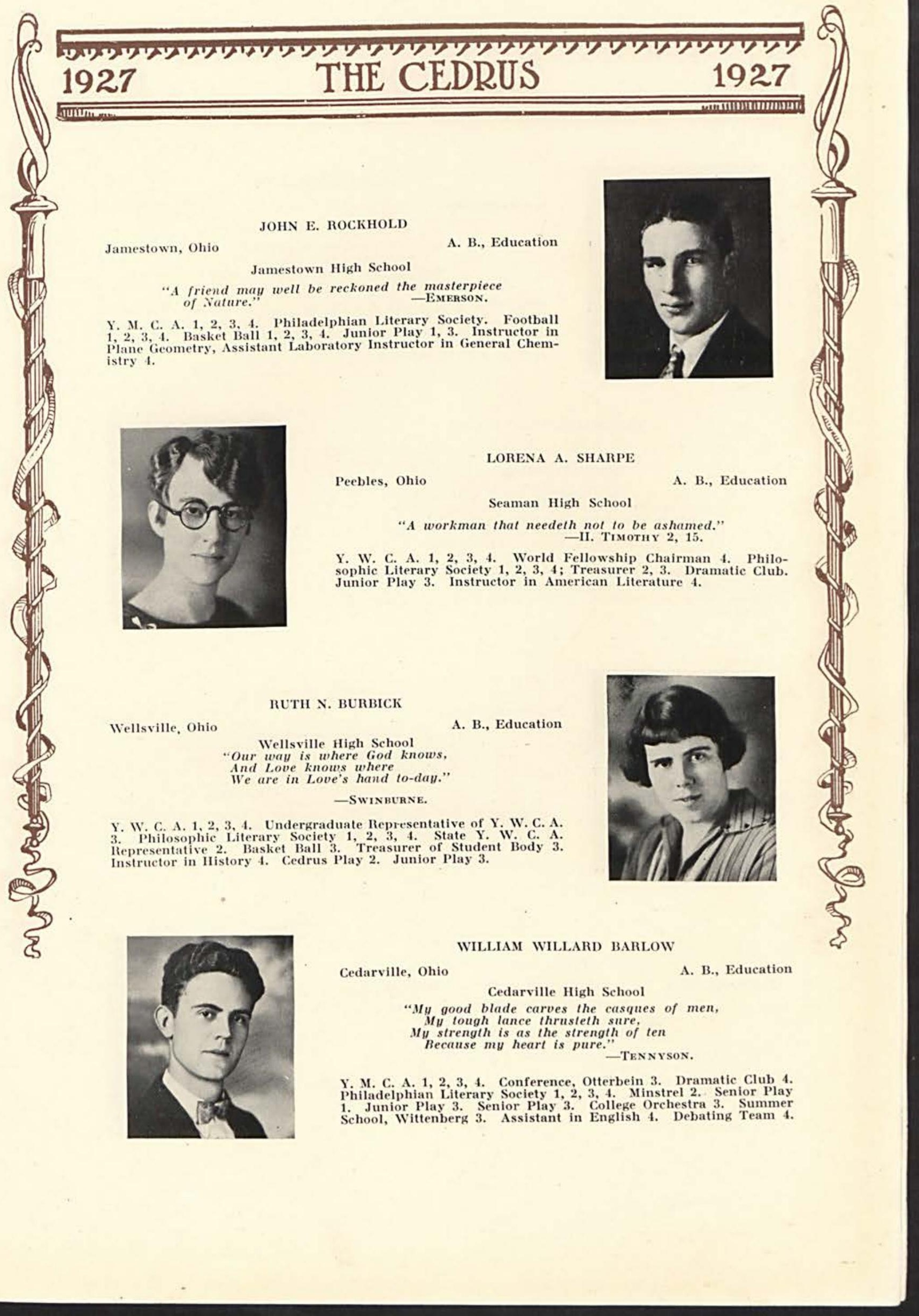




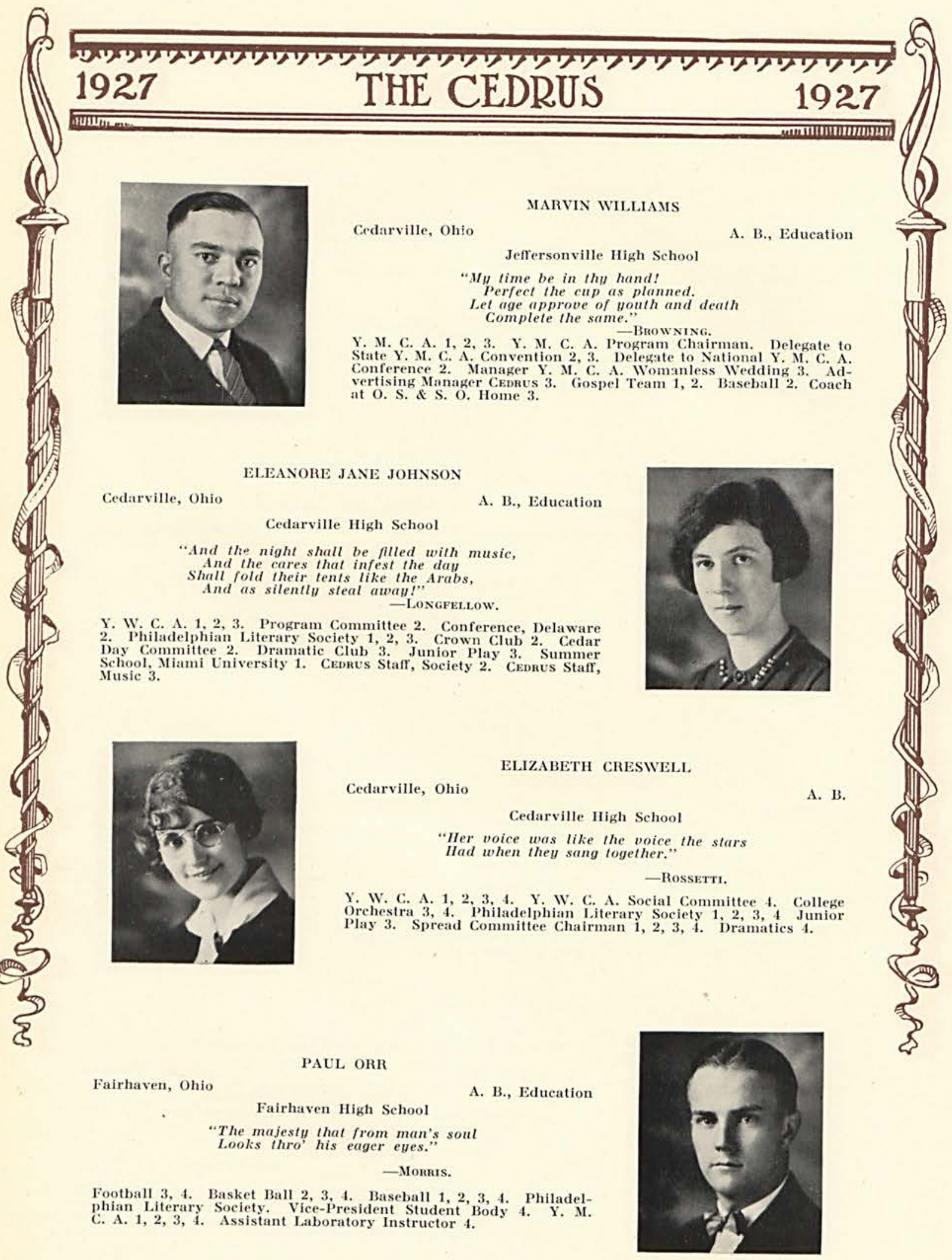




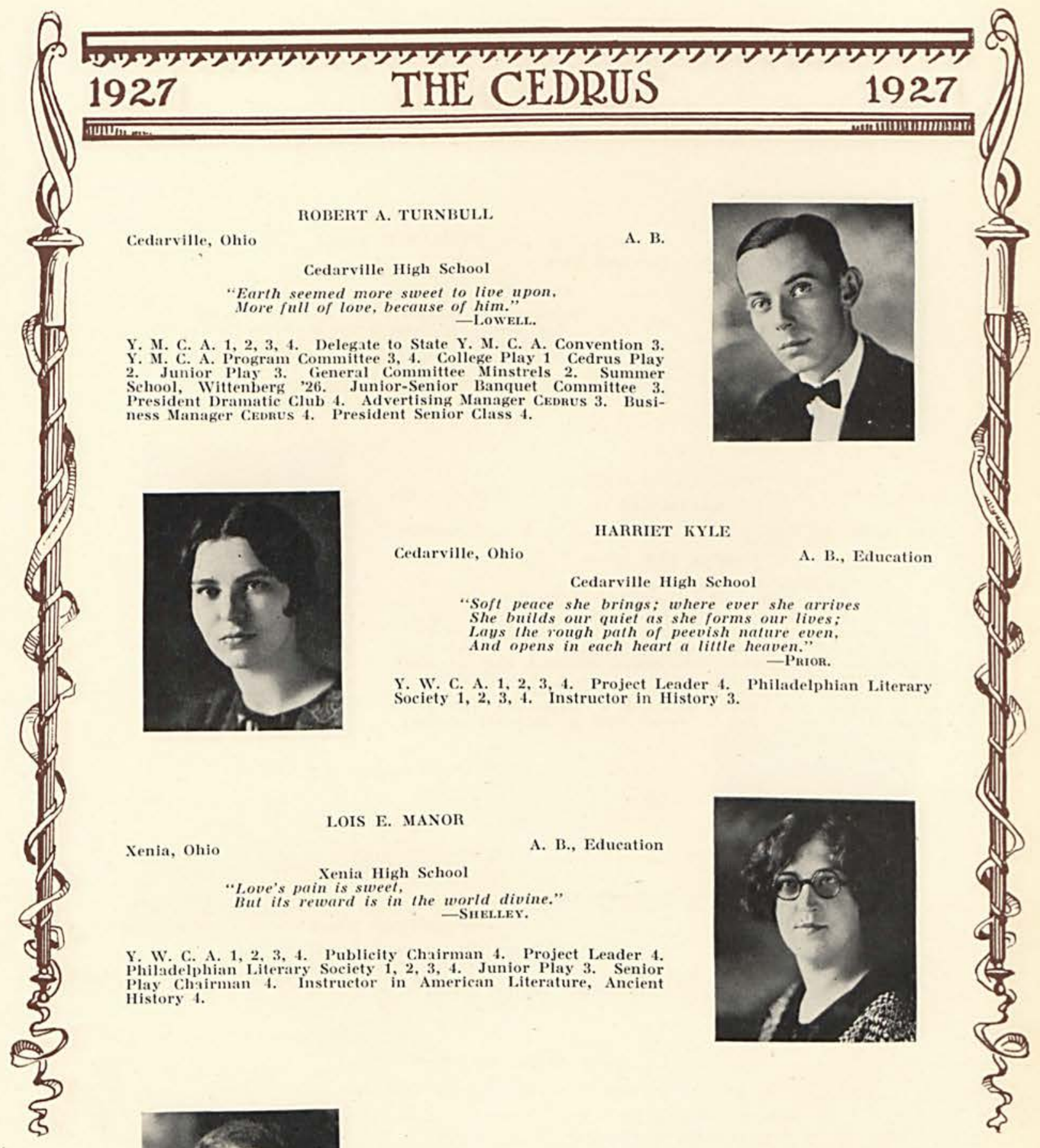

LLOYD MeCAMIPBELL.

Cedarville, Ohio

A. B., B. S.

Cedarville High School

"A good man possesses a Kingdom."

Y. M. C. A. 1, 2, 3, 4. Womanless Wedding 


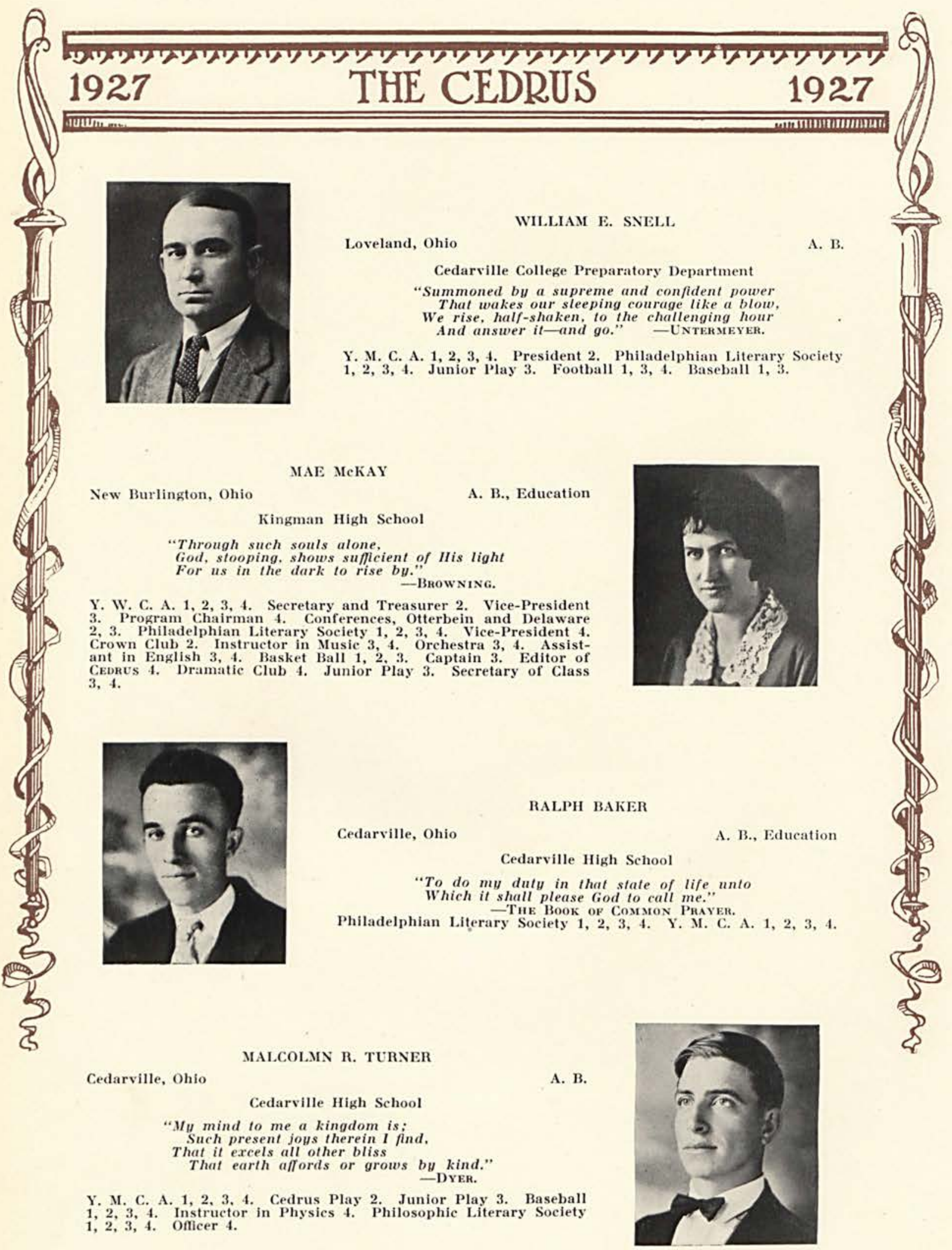




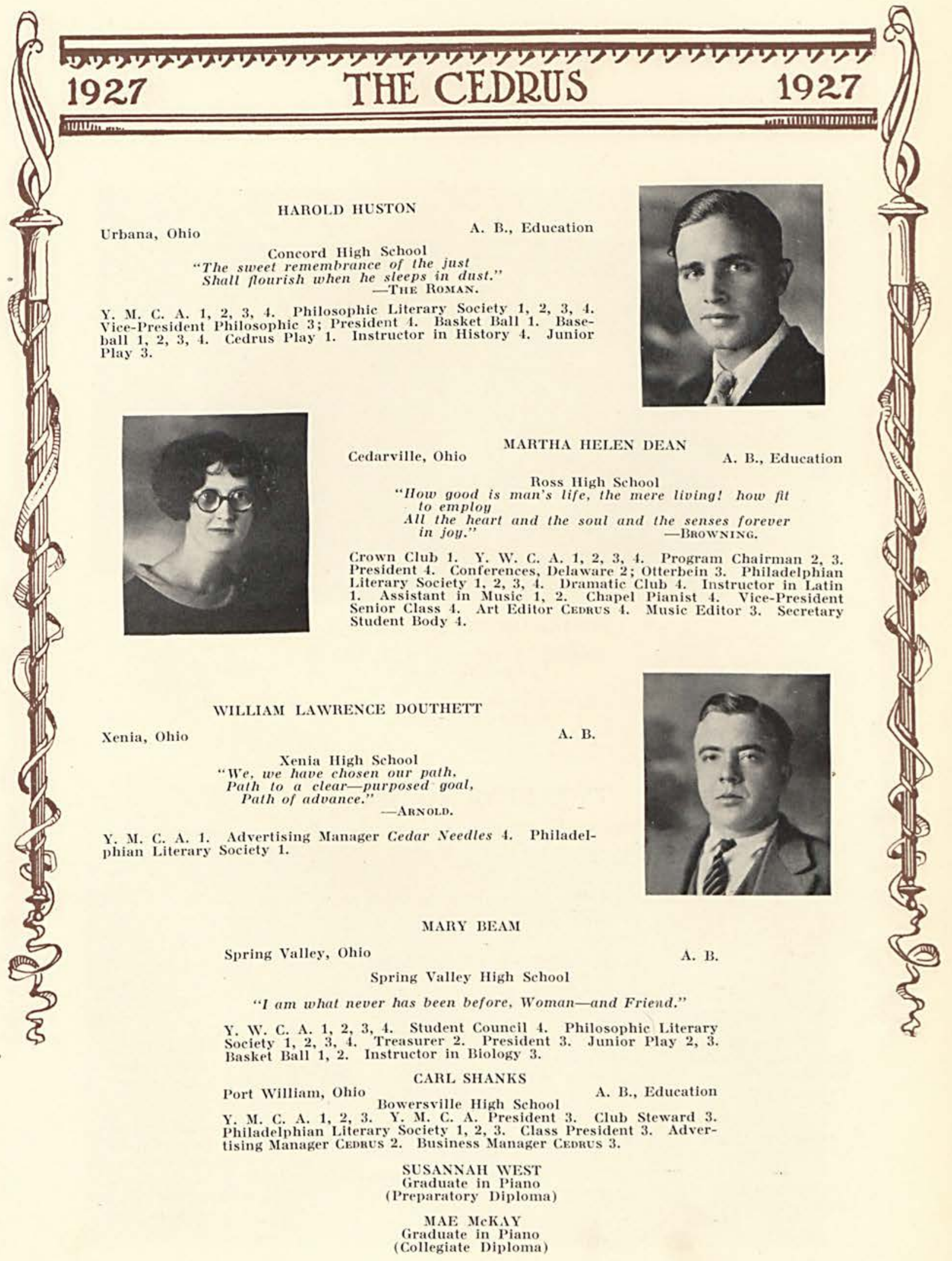




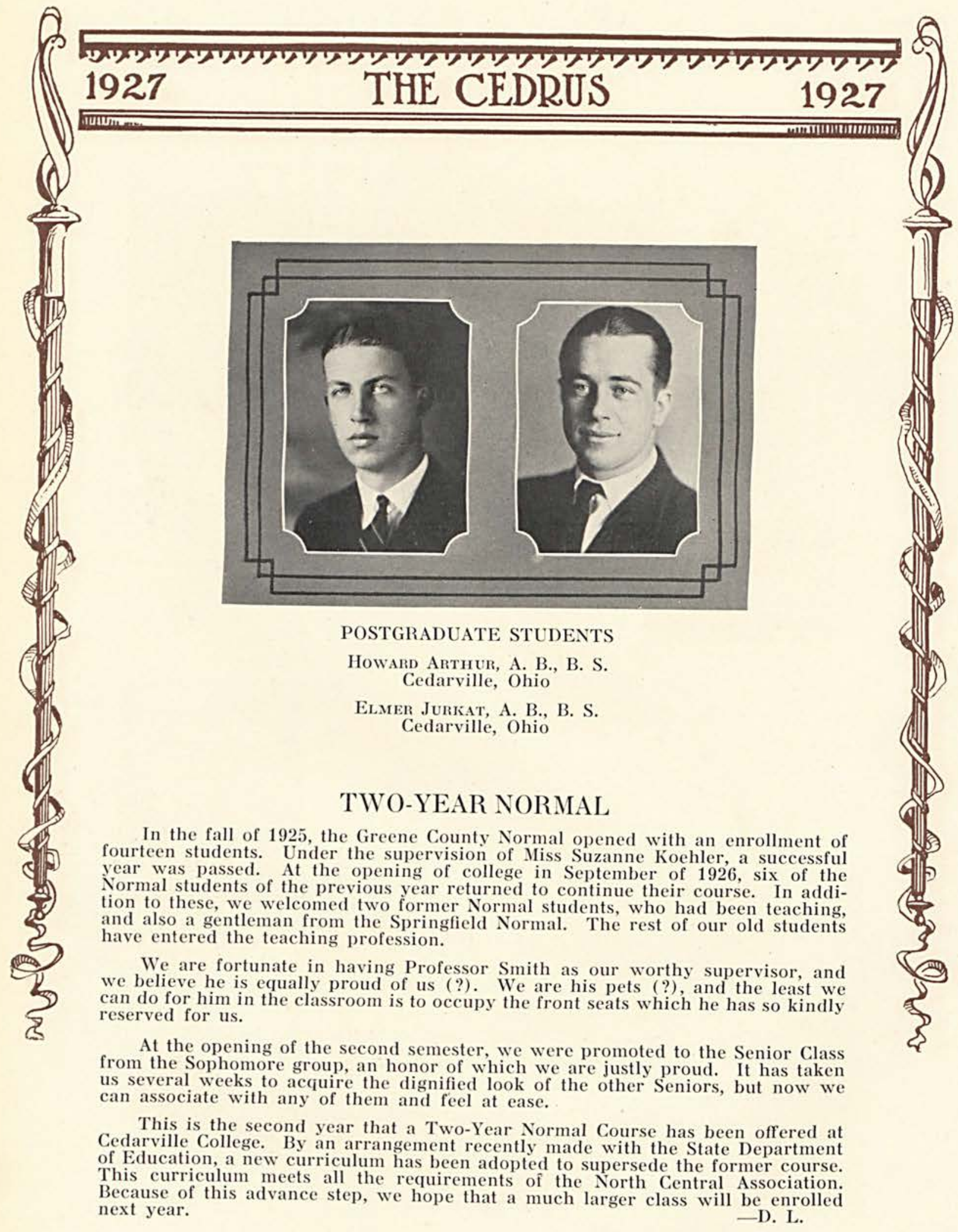




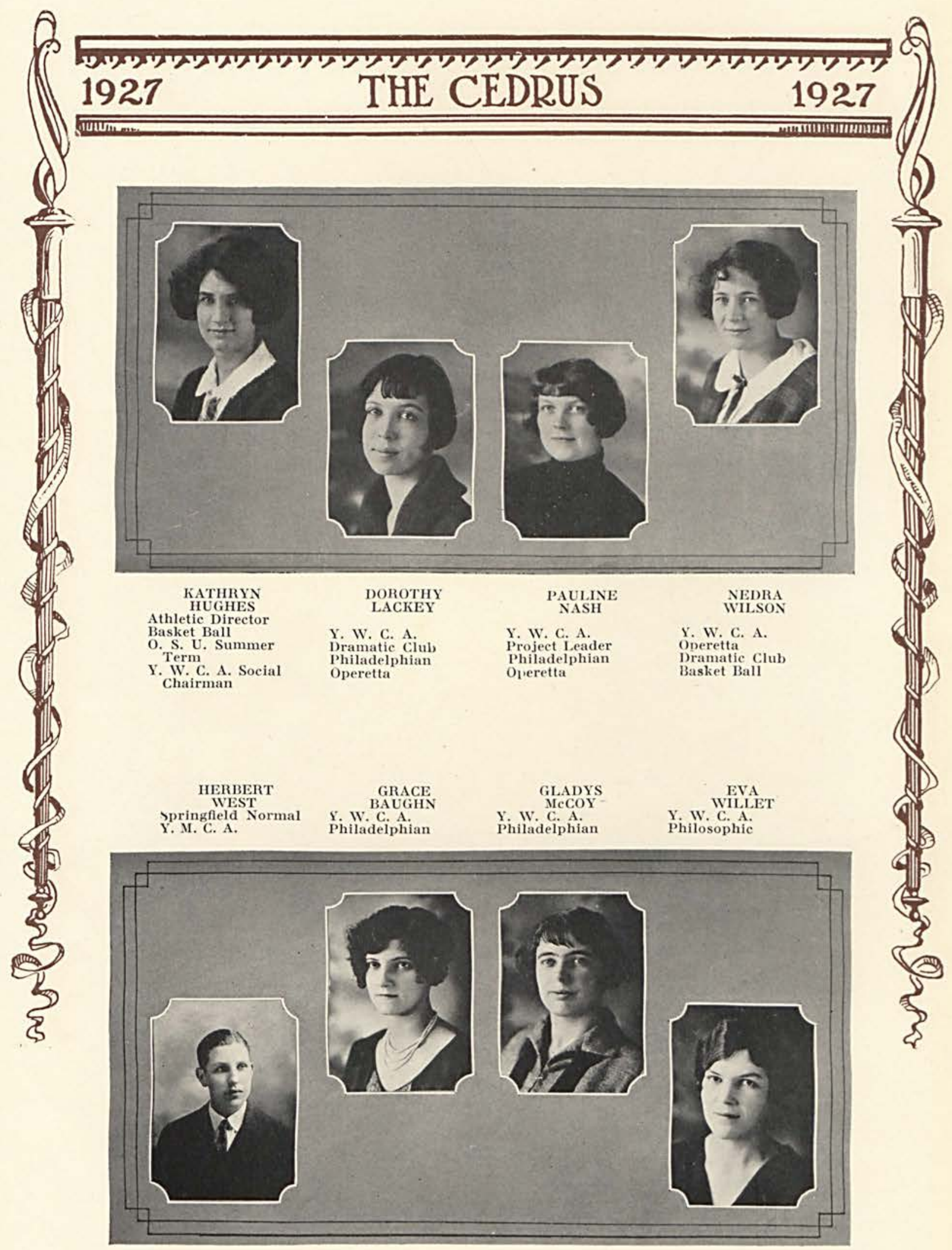




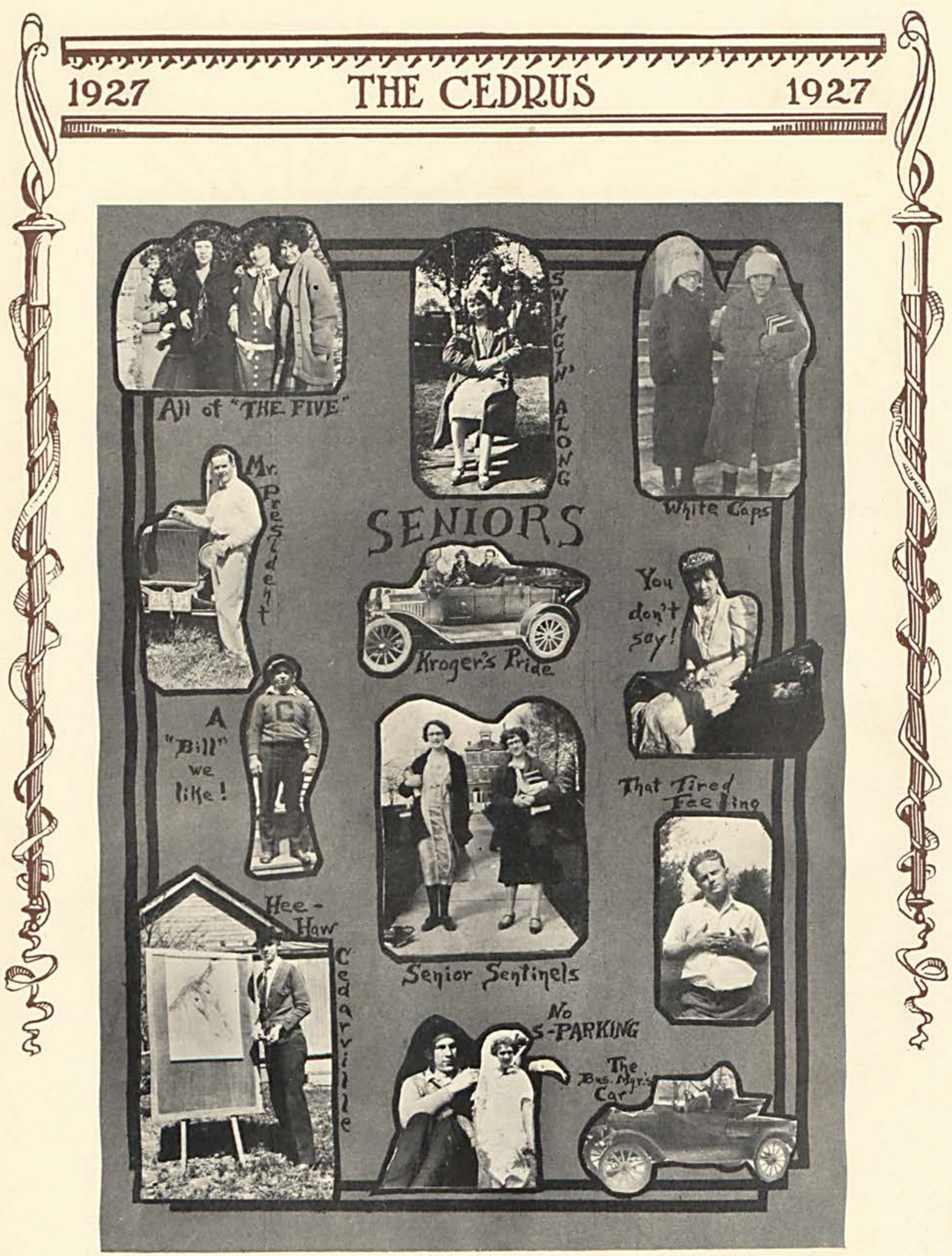




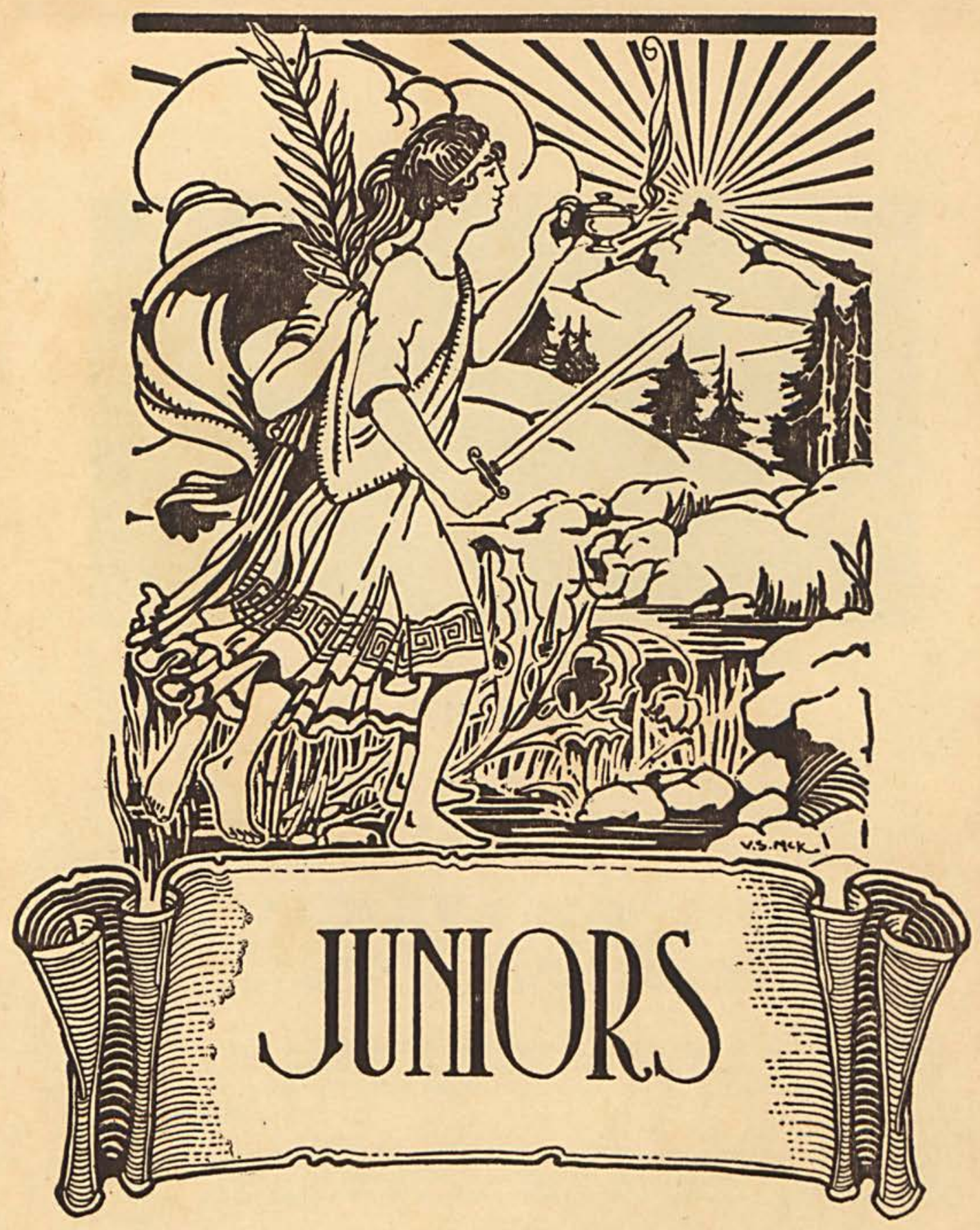





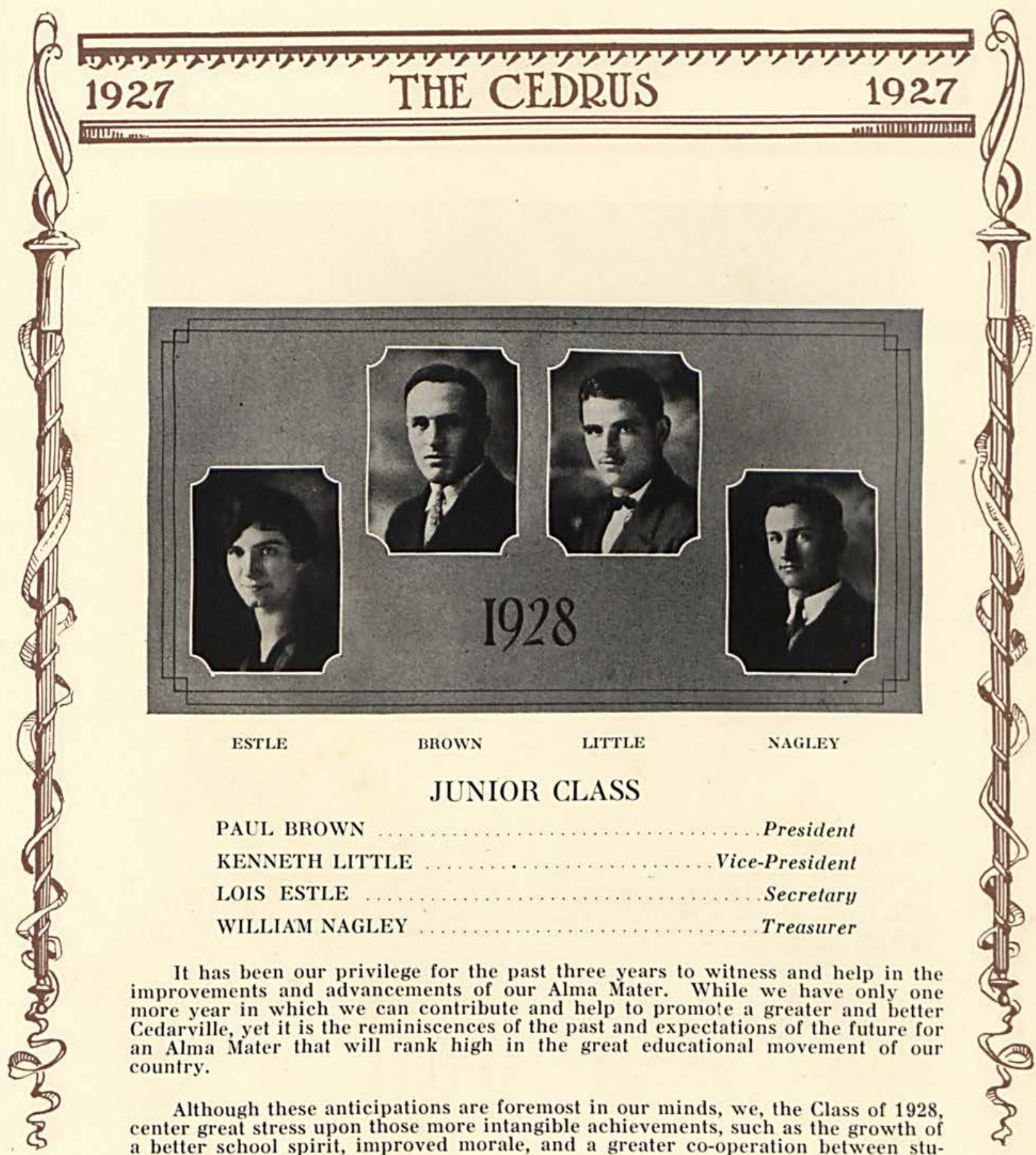
dents and faculty.

These we set as our goal in order that the Junior Class of Cedarville College may create a permanent impression, and that we may continue to strive to keep our college on the high and noble plane where it has stood and been recognized for years. 


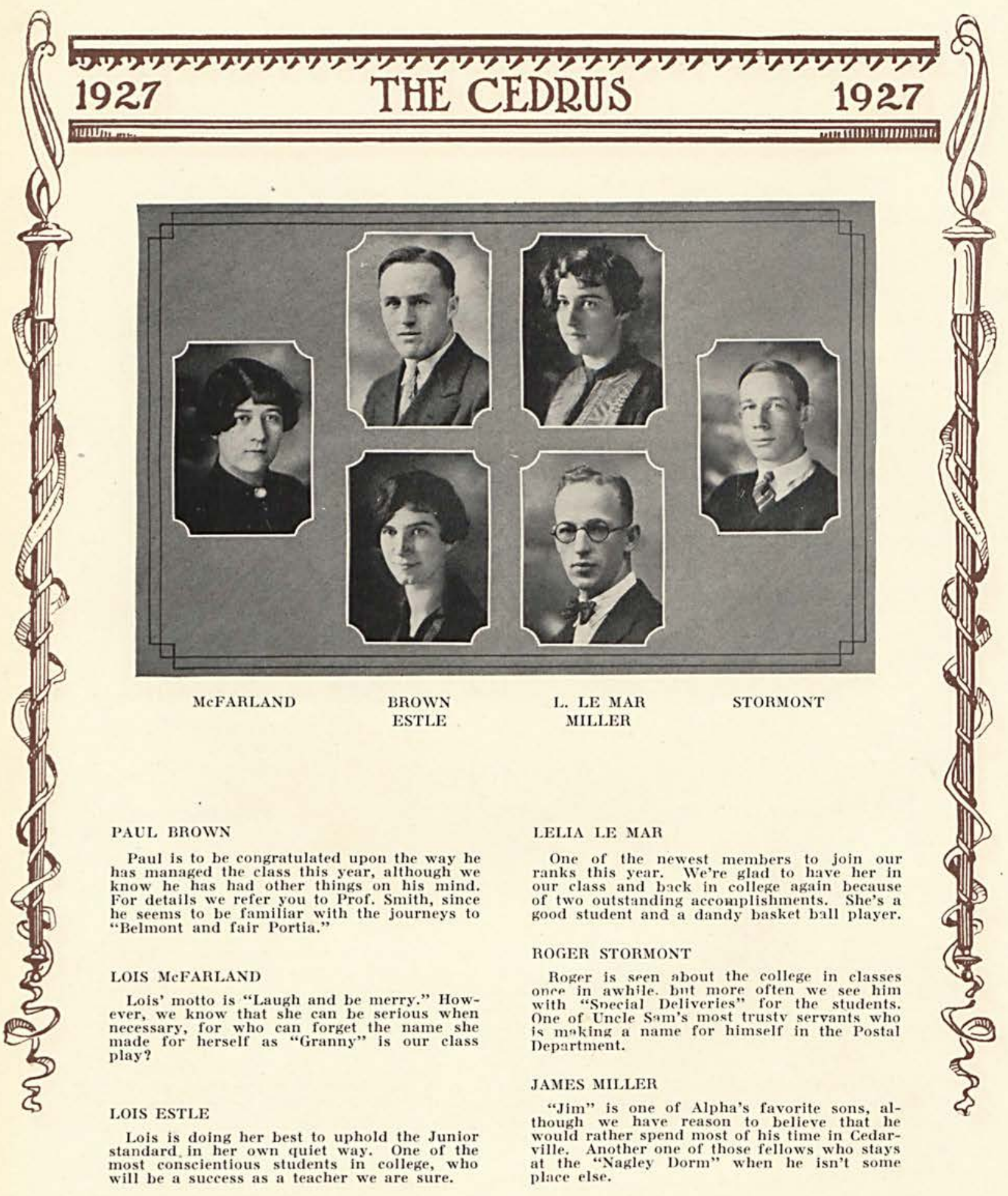




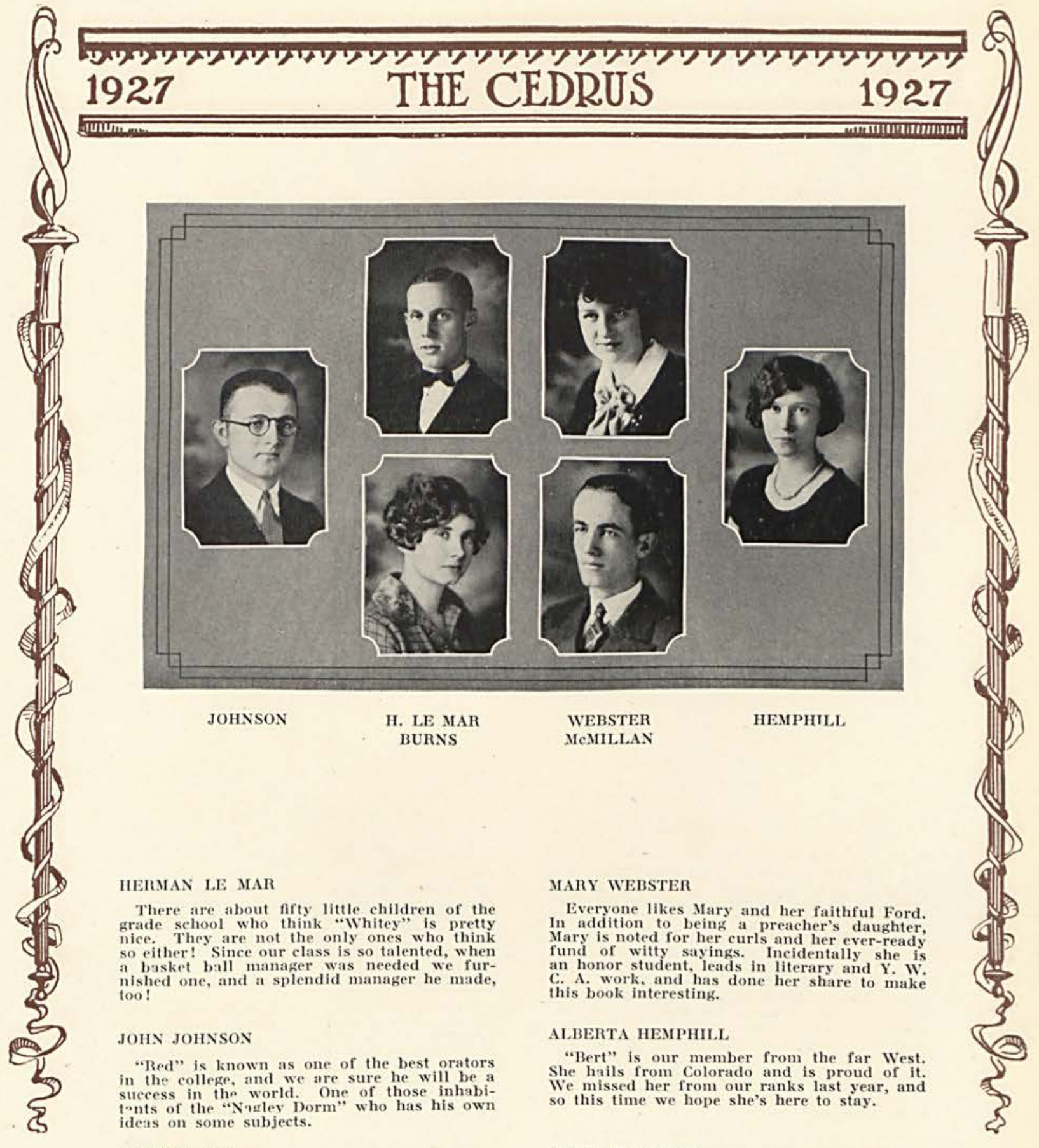

\section{RUTH BURNS}

It wasn't until the second semester we discovered the fact that Ruth was leaving our covered the fact that Ruth was leaving our ranks and becoming, a senior. her start in such an illustrious class as ours.

\section{JAMES MEMILLAN}

"Jimmie" is known as one of Cedarville's promising young business men. However, even with all his cares in the business world he finds time to indulge in his favorite sport -riding out the Clark's Run road. 


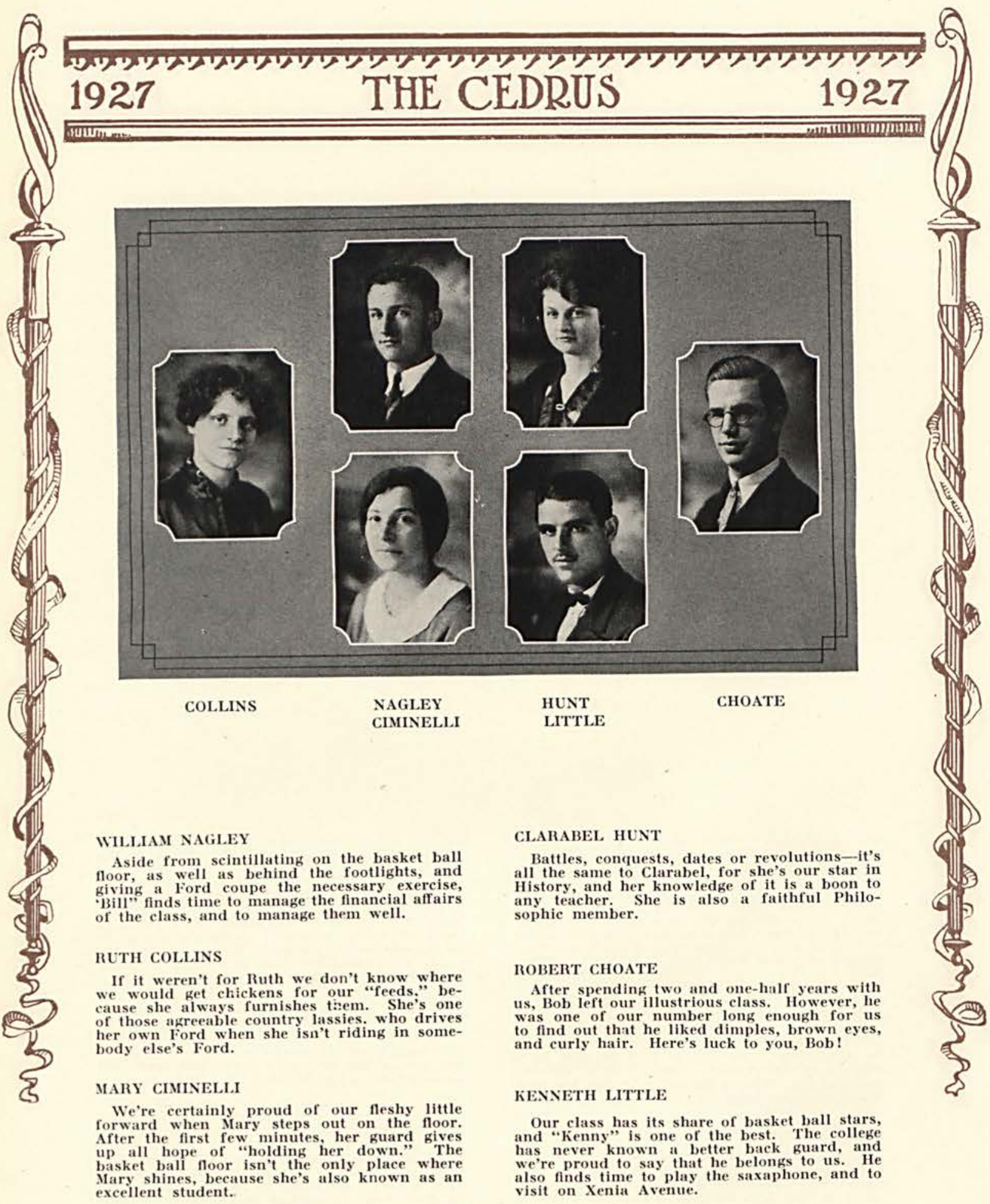




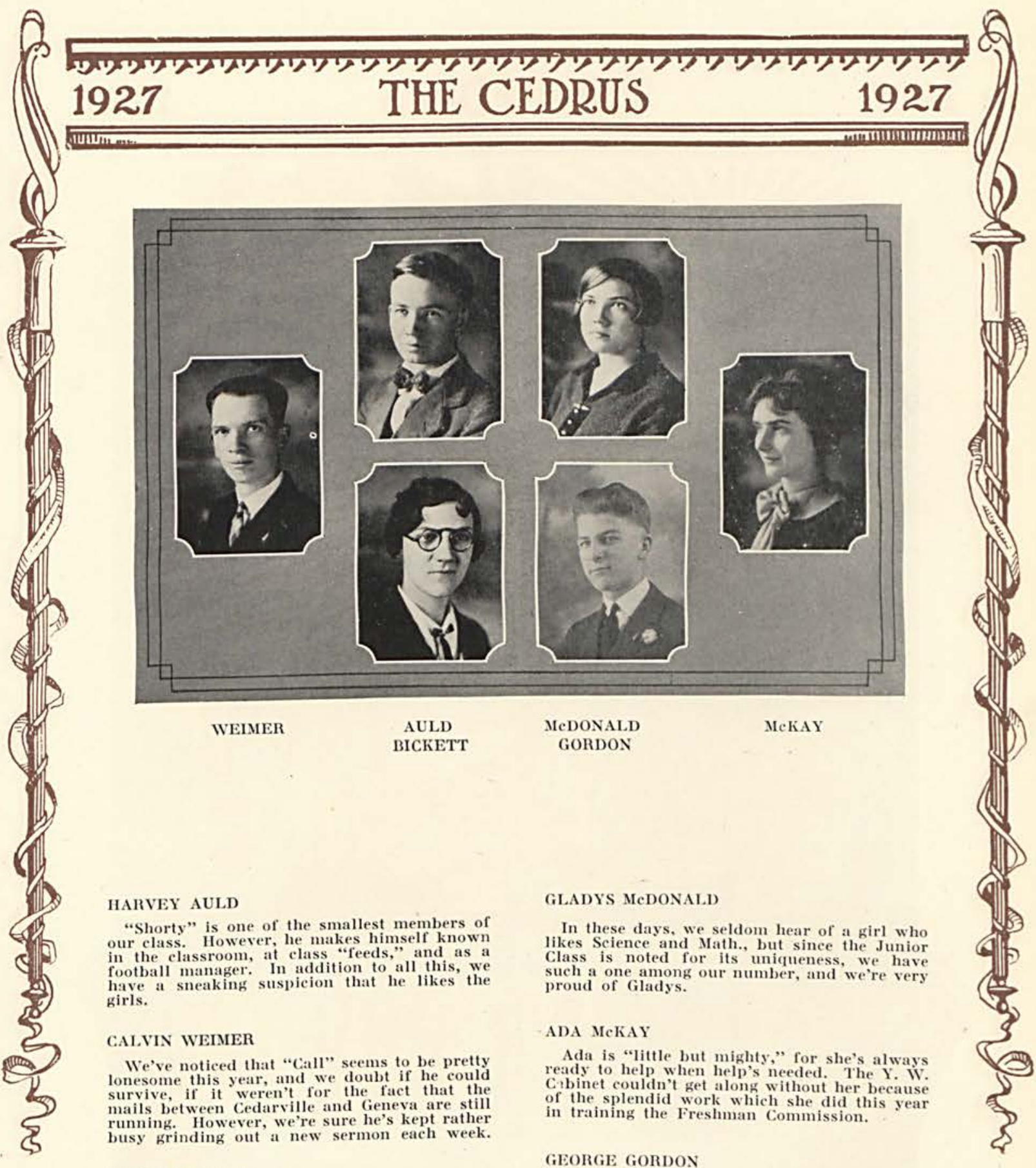

\section{WILDA BICKETT}

Wilda is our representative member from Xenia, and we're sure the county seat must be proud of its products. We know that she likes Latin, Botany Lab., and rides in a Ford sedan.

\section{EORGE GORDON}

We're quite sure "Bunk" has keen kept busy this year, clerking in the store, playing basket ball, and "attending" classes. We know, too, that he likes to journey to Springfield quite often, although we can't imagine the reason
why. 


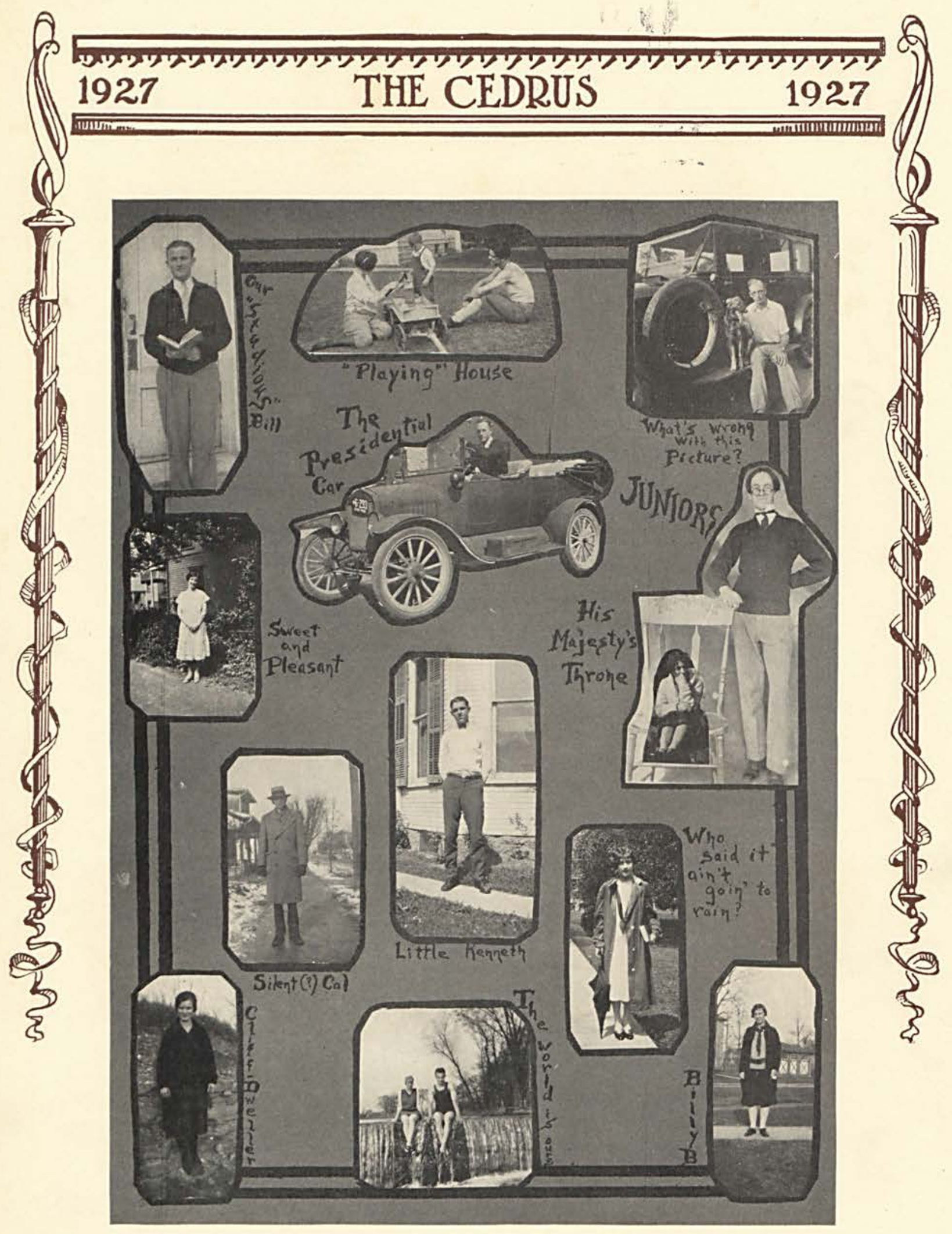




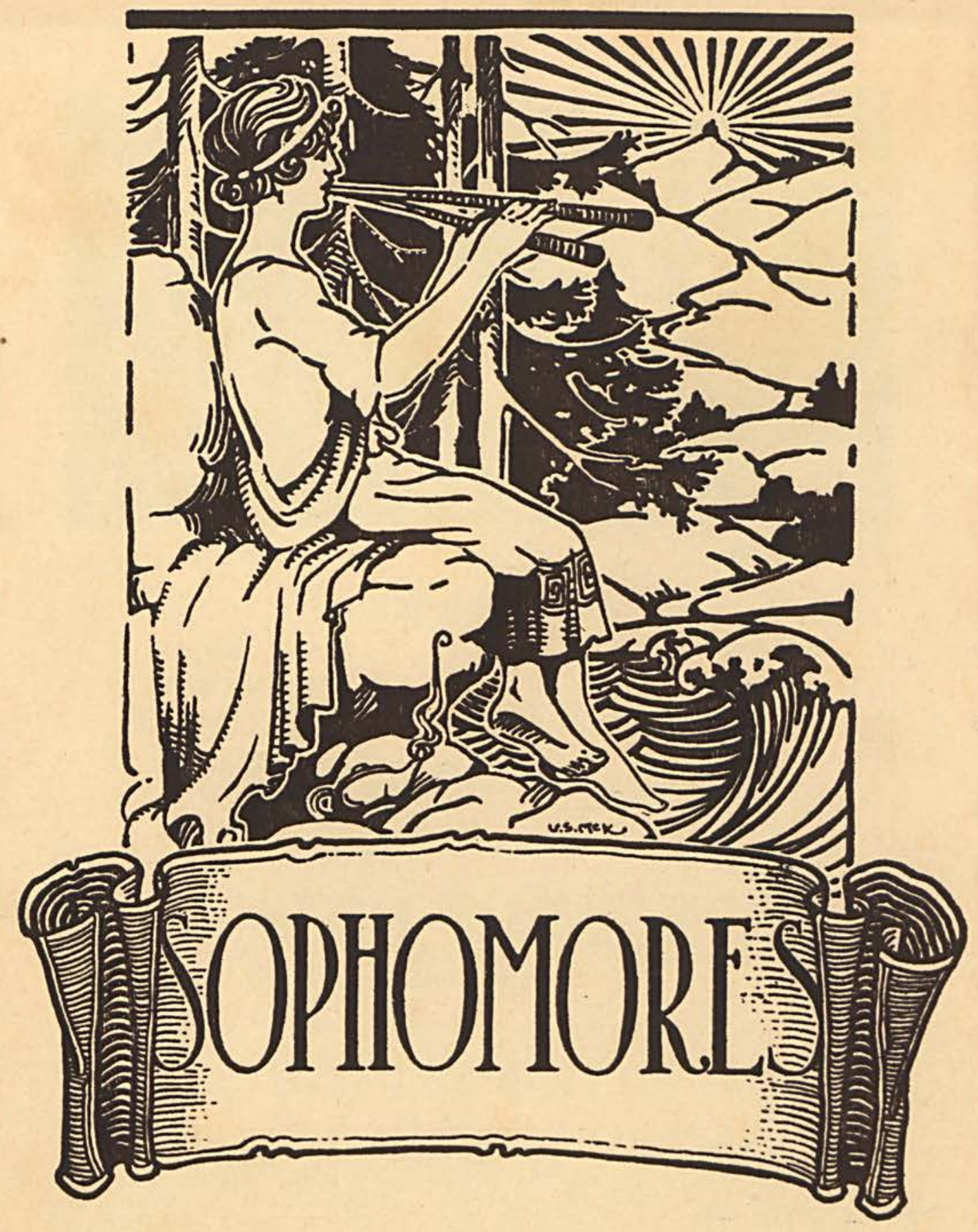





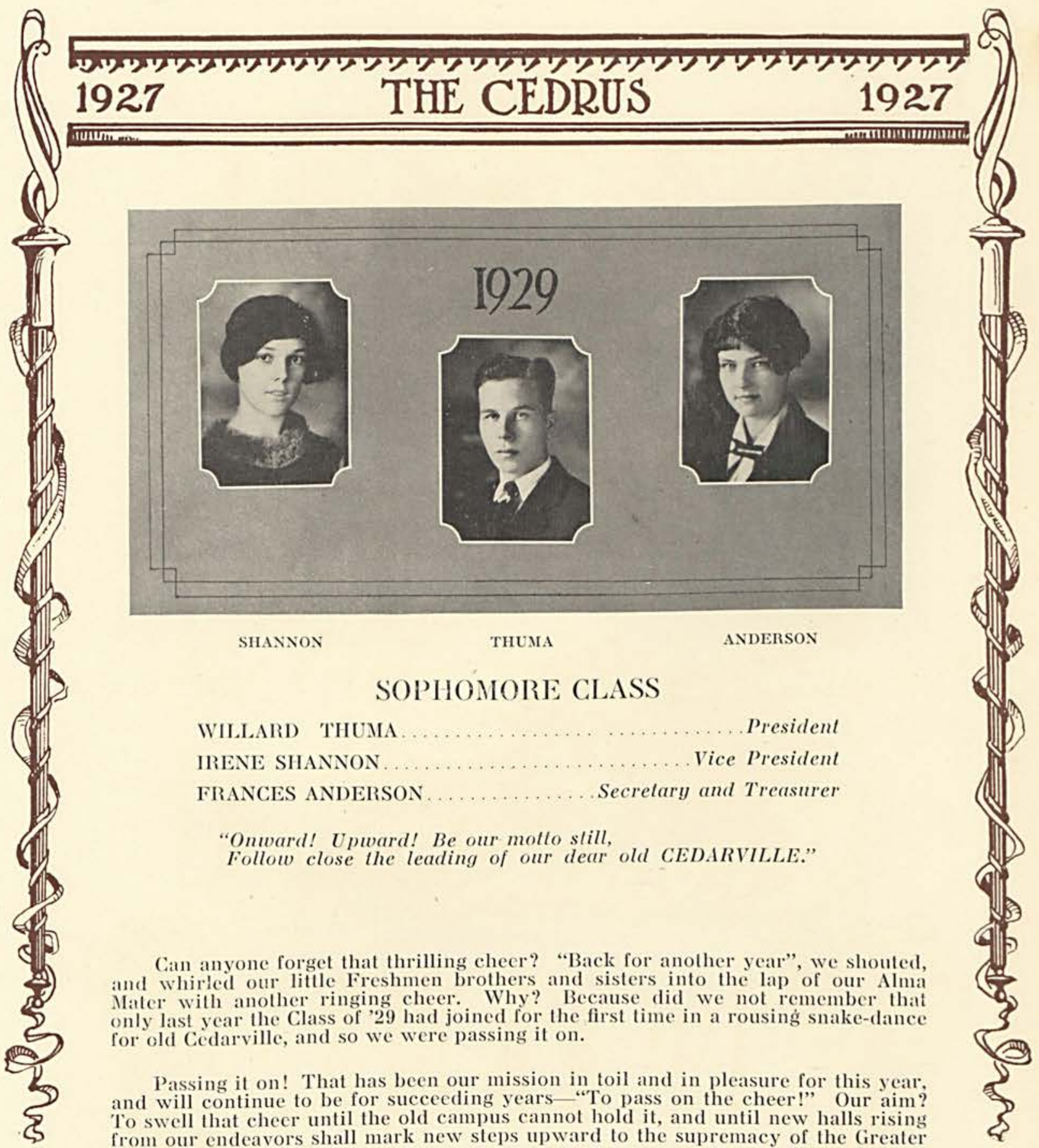

from our endeavors shall mark new steps upward to the supremacy of the Greater Cedarville.

We are not unmindful of our last year's resolution to write the history of our four years' activities with indelible Orange and Blue upon the living memories of our Alma Mater. We have given of our best. The Class of ' 29 has been true to her trust and today her coat-of-arms of loyal, ro y a I Blue still flaunts the Orange "C".

-M. D. 


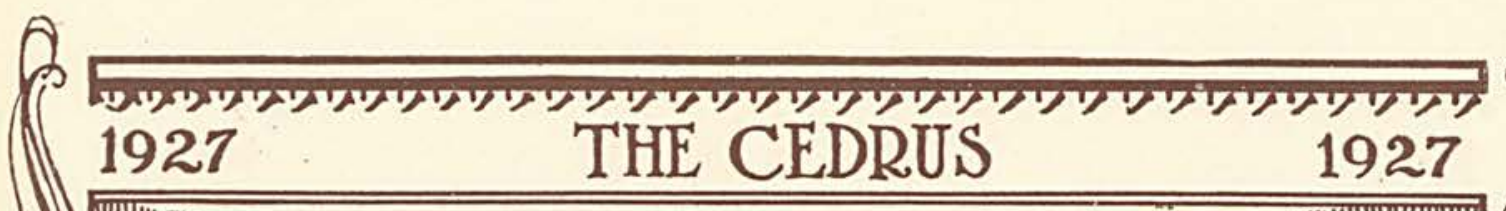

(1)
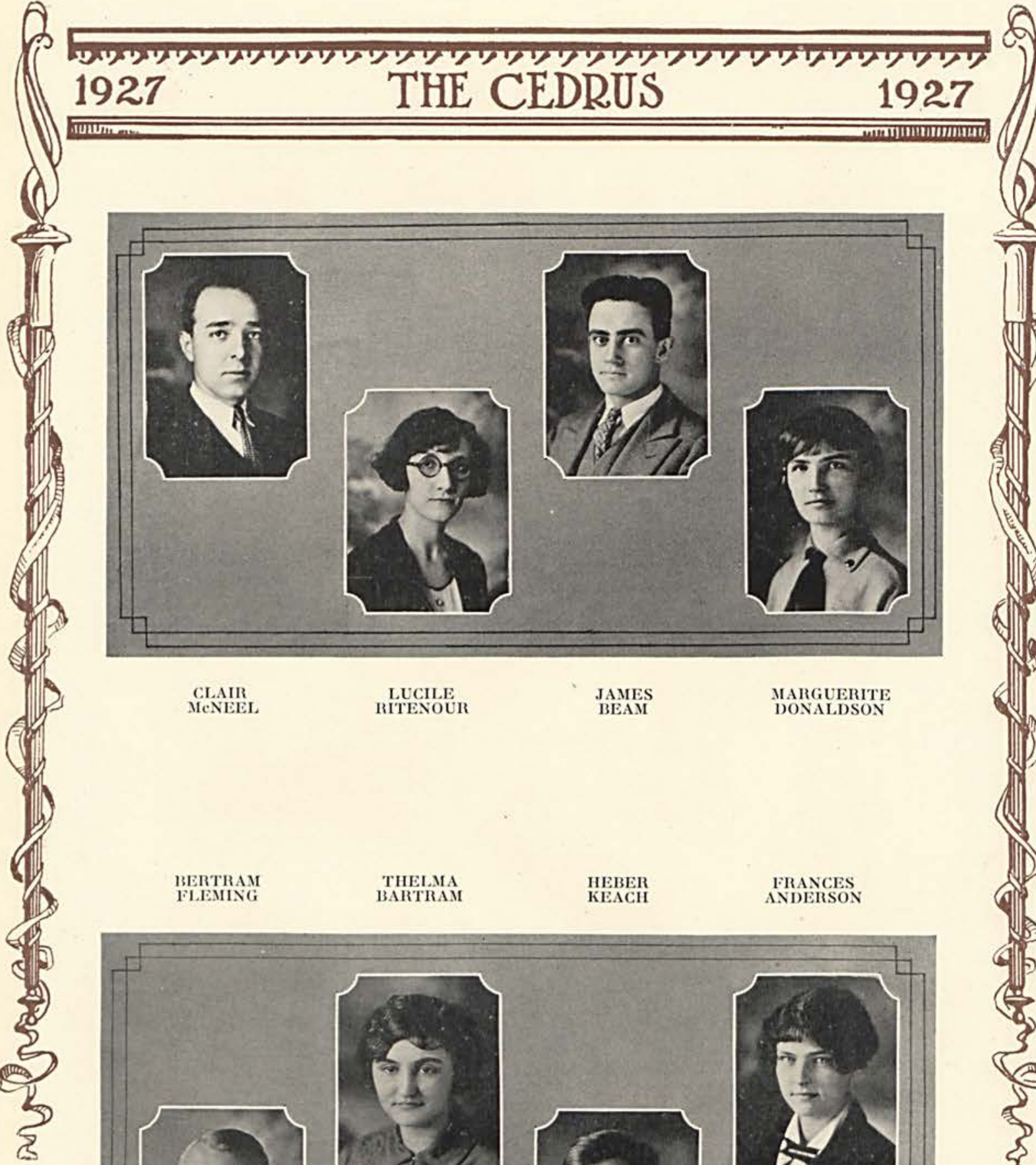

CLAIR

LUCILE

IAMES

AARGUERITE

DONALDSON
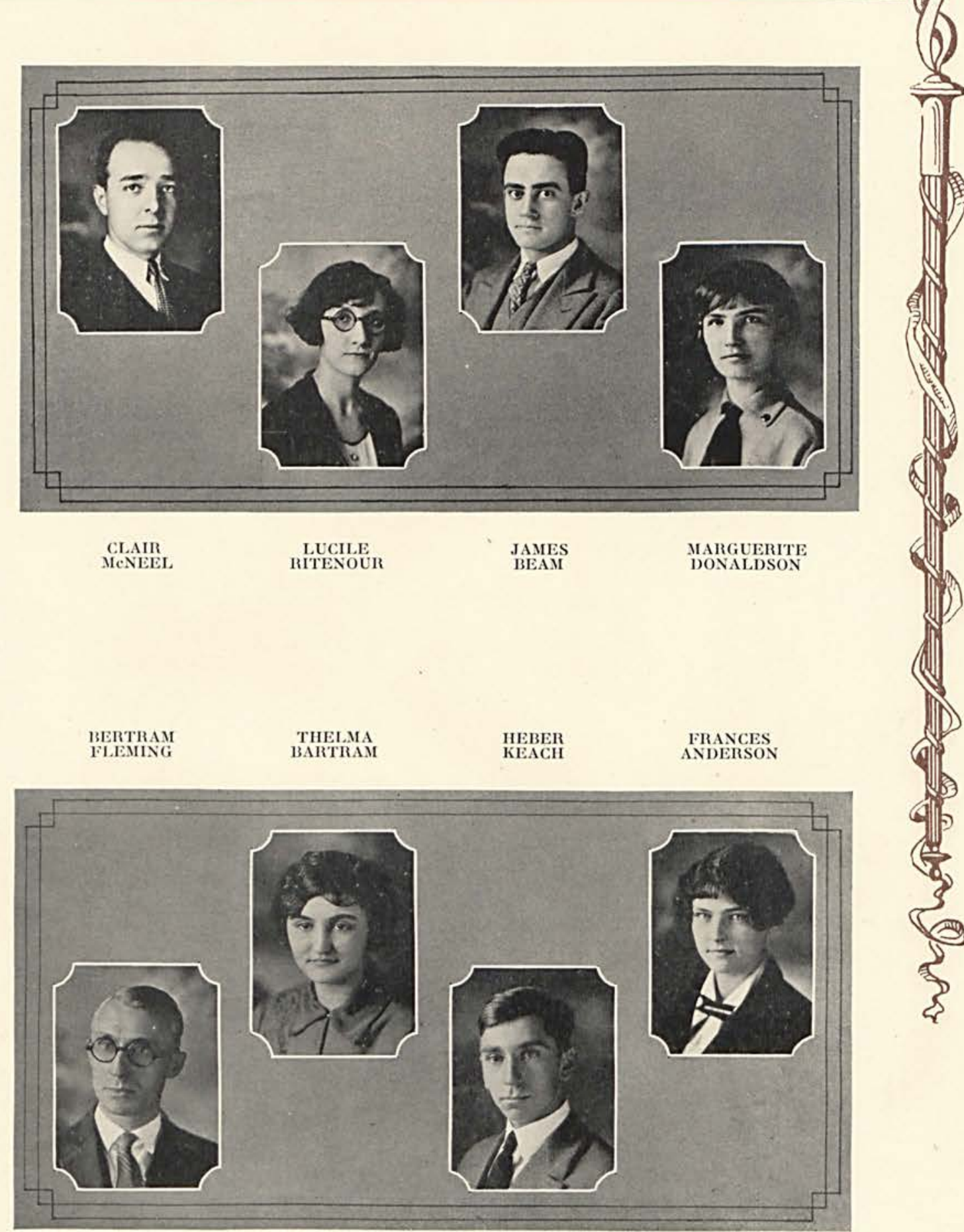


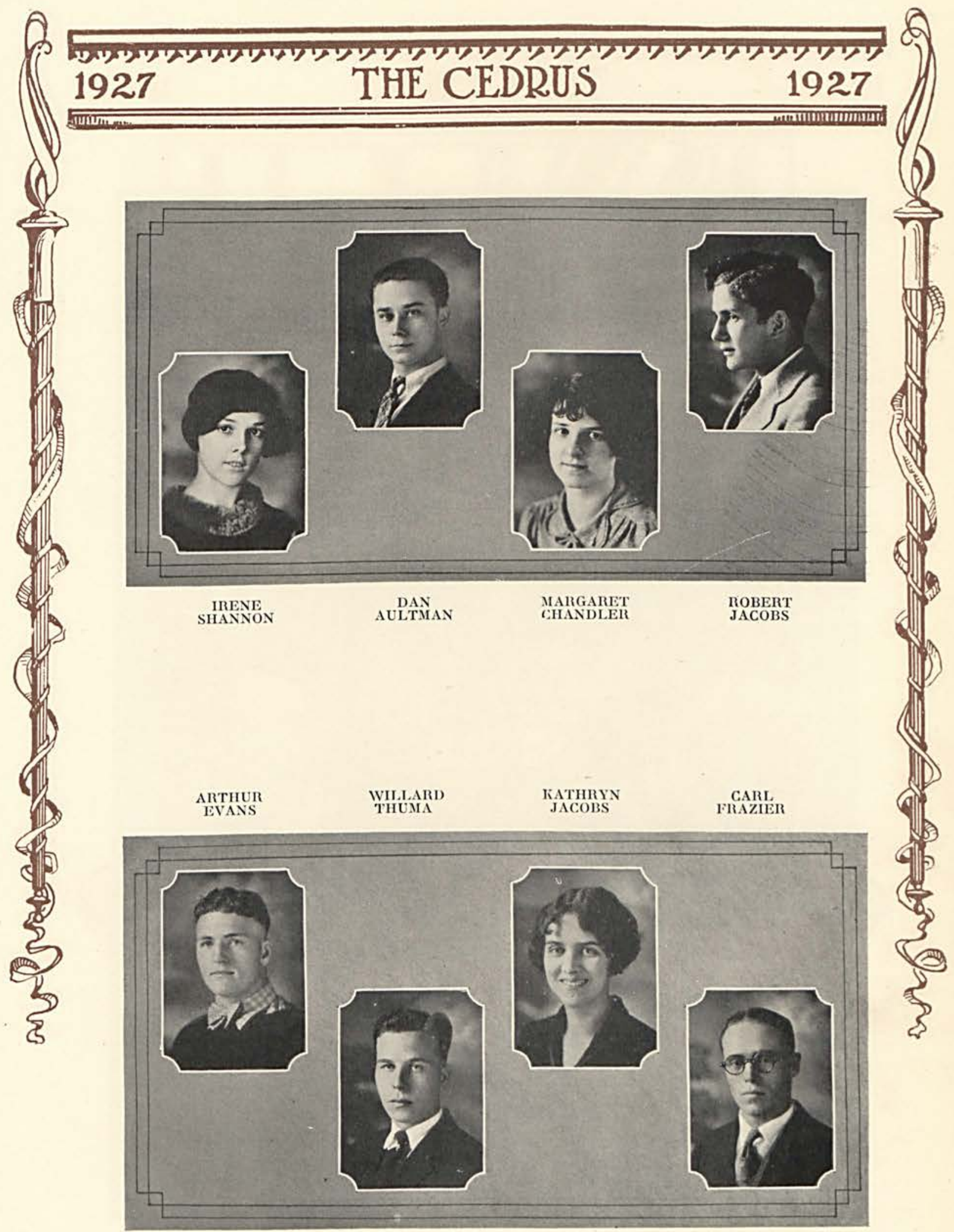




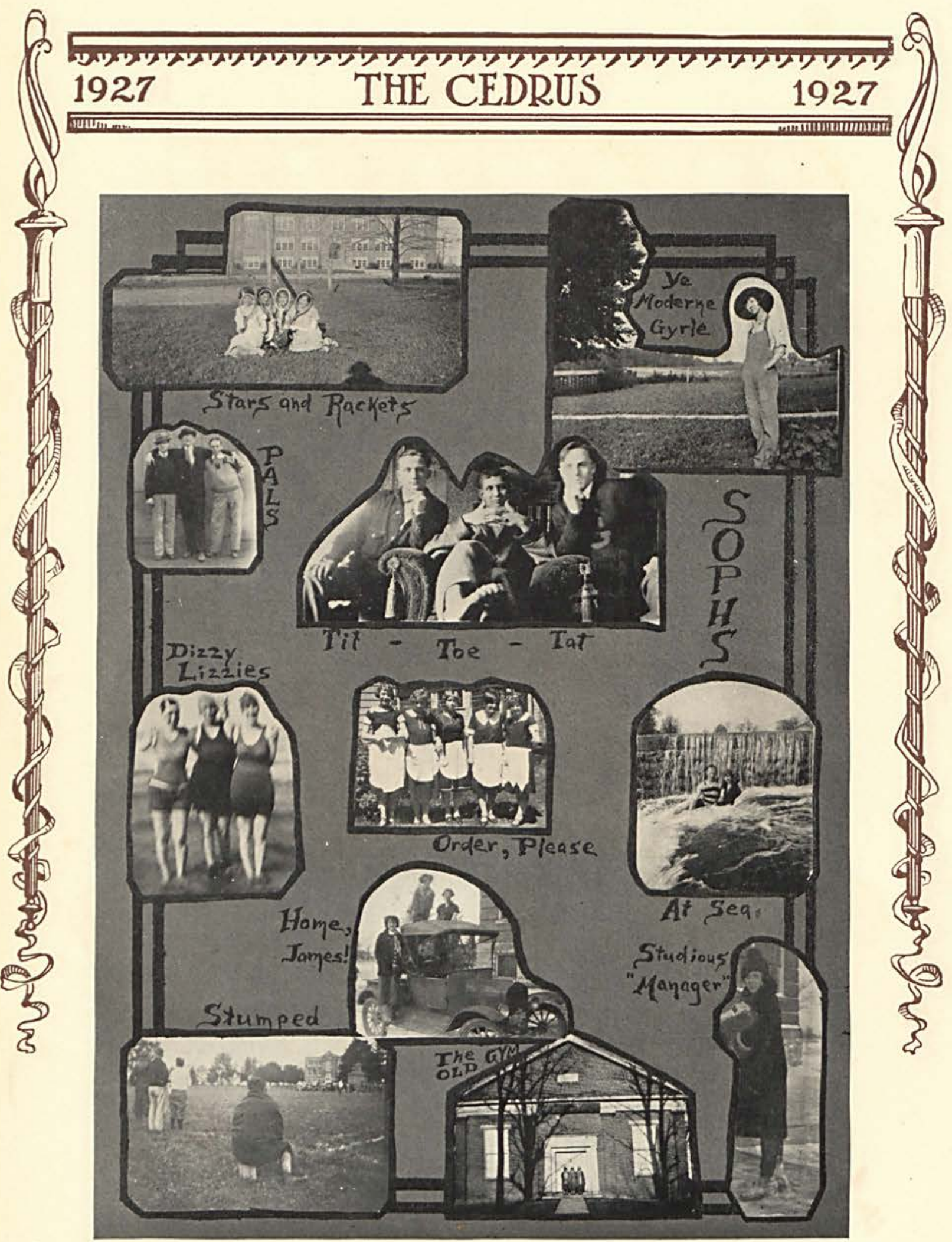




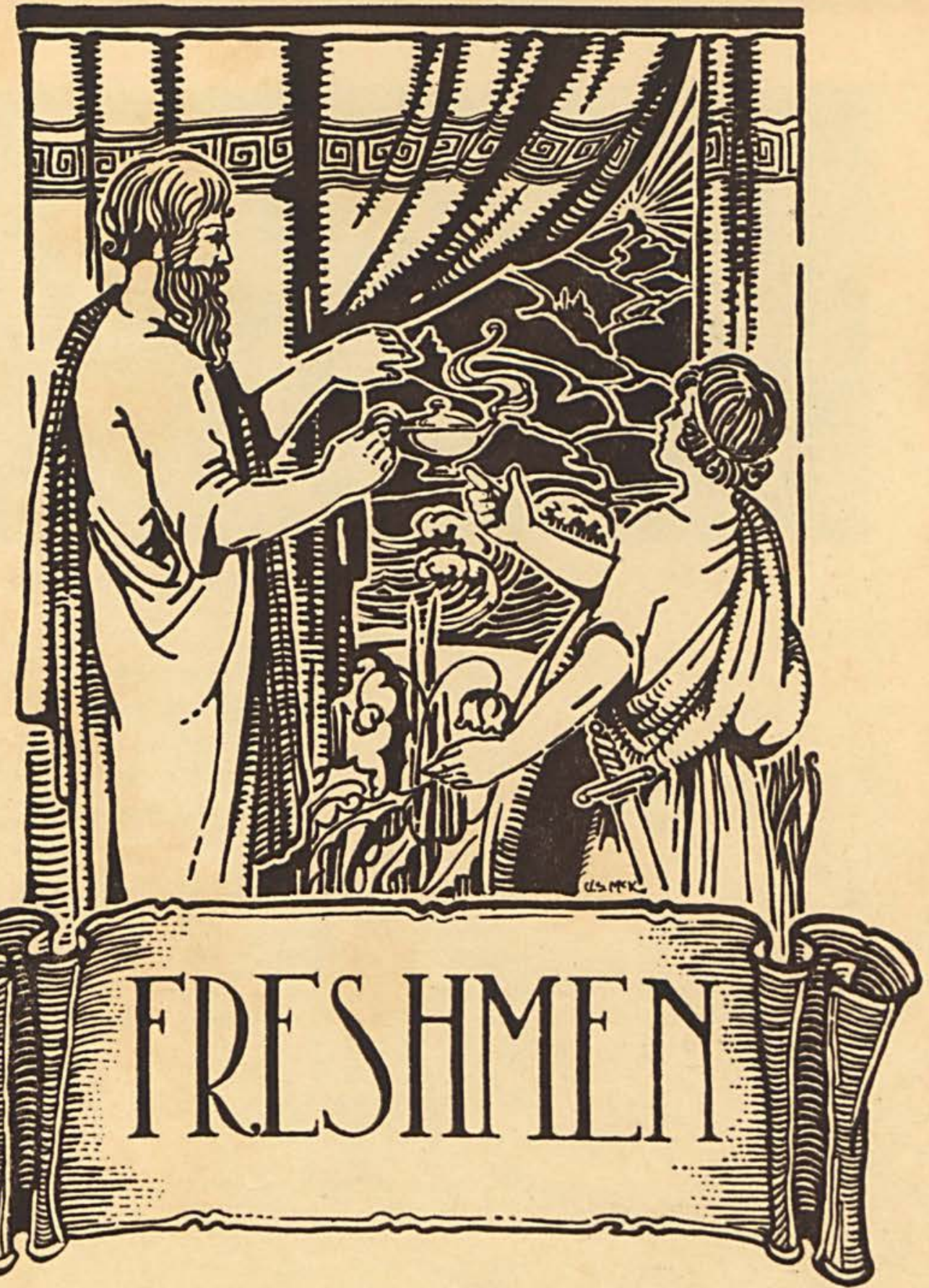





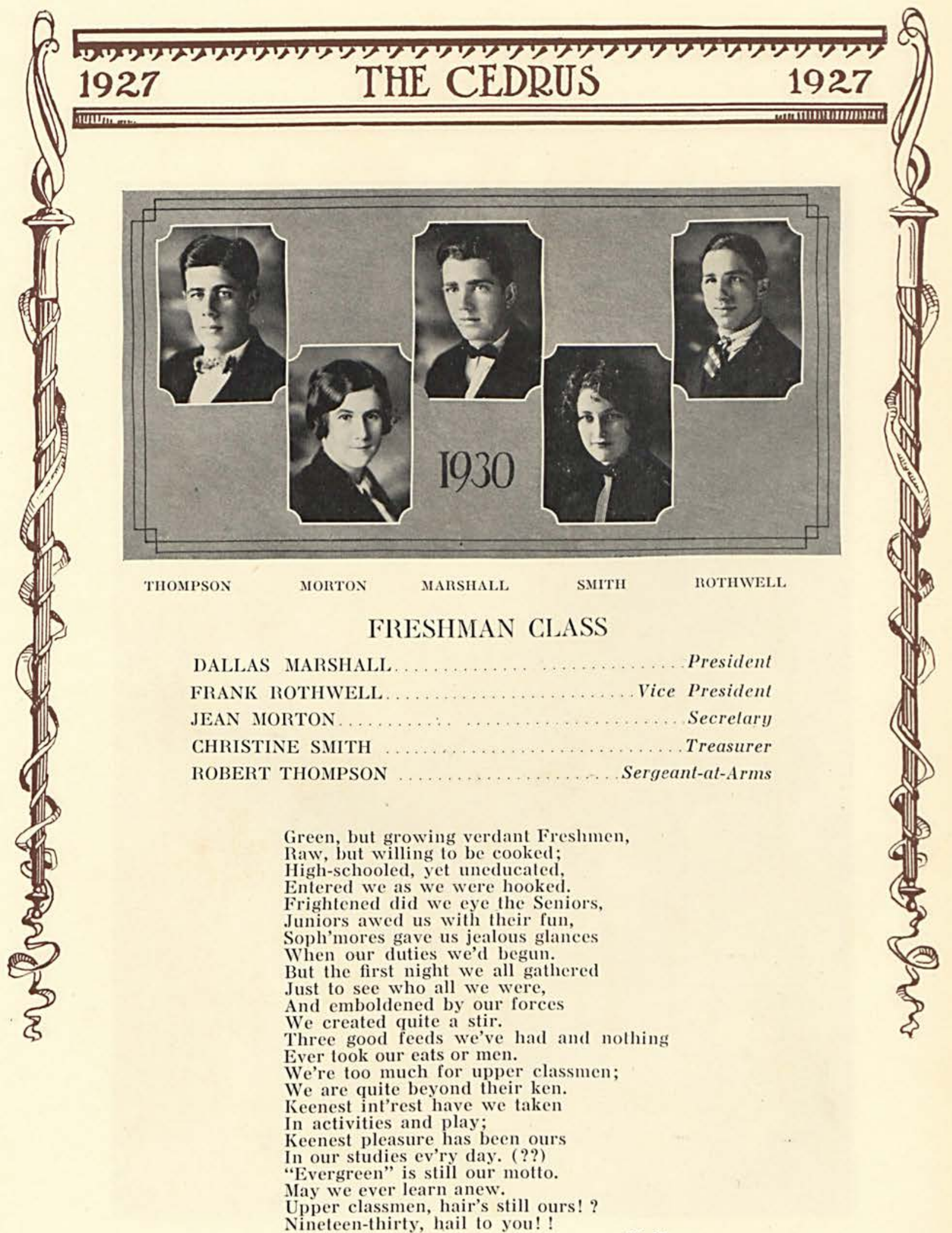

-F. M. 


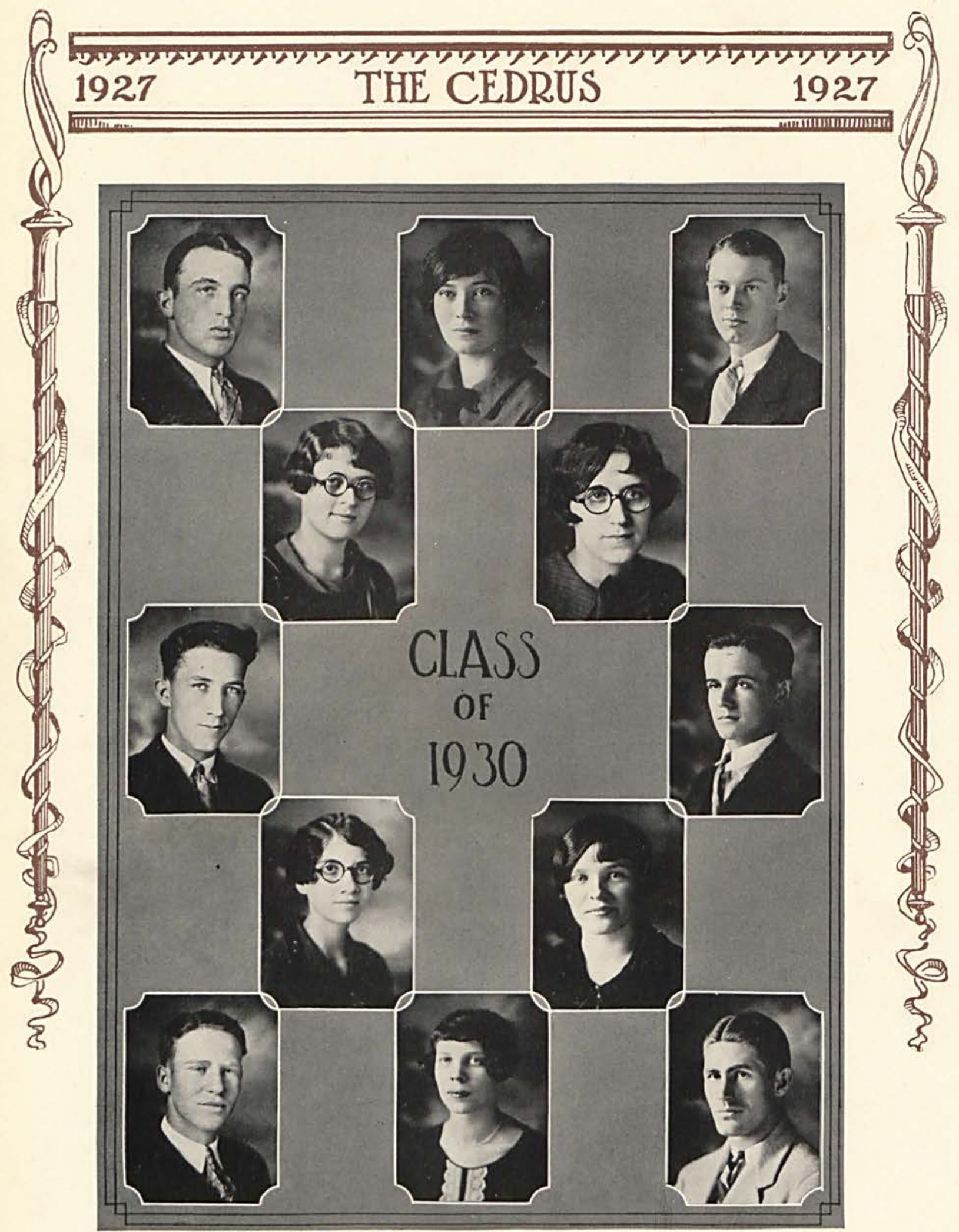

FRESHMEN 


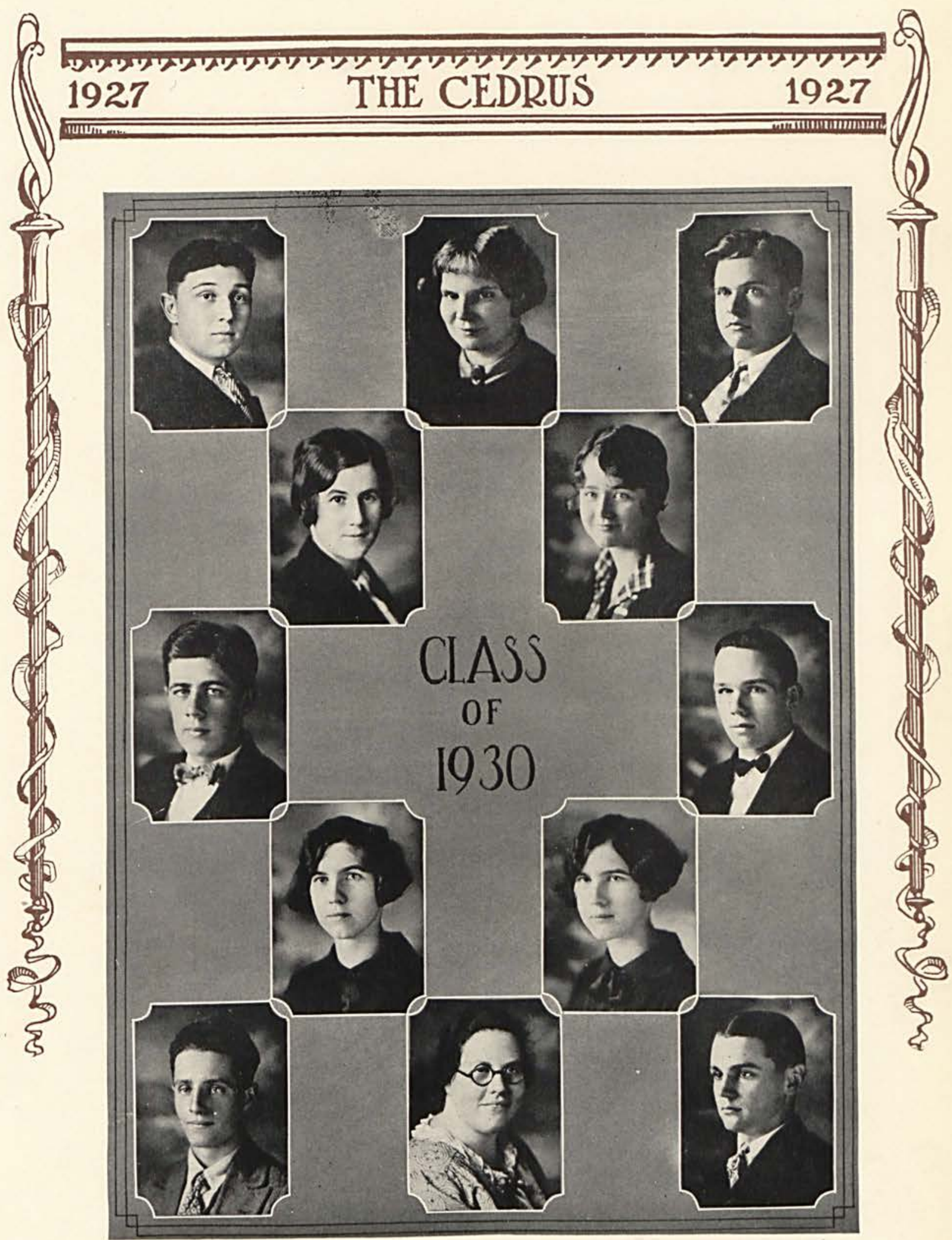

FRESHMEN 


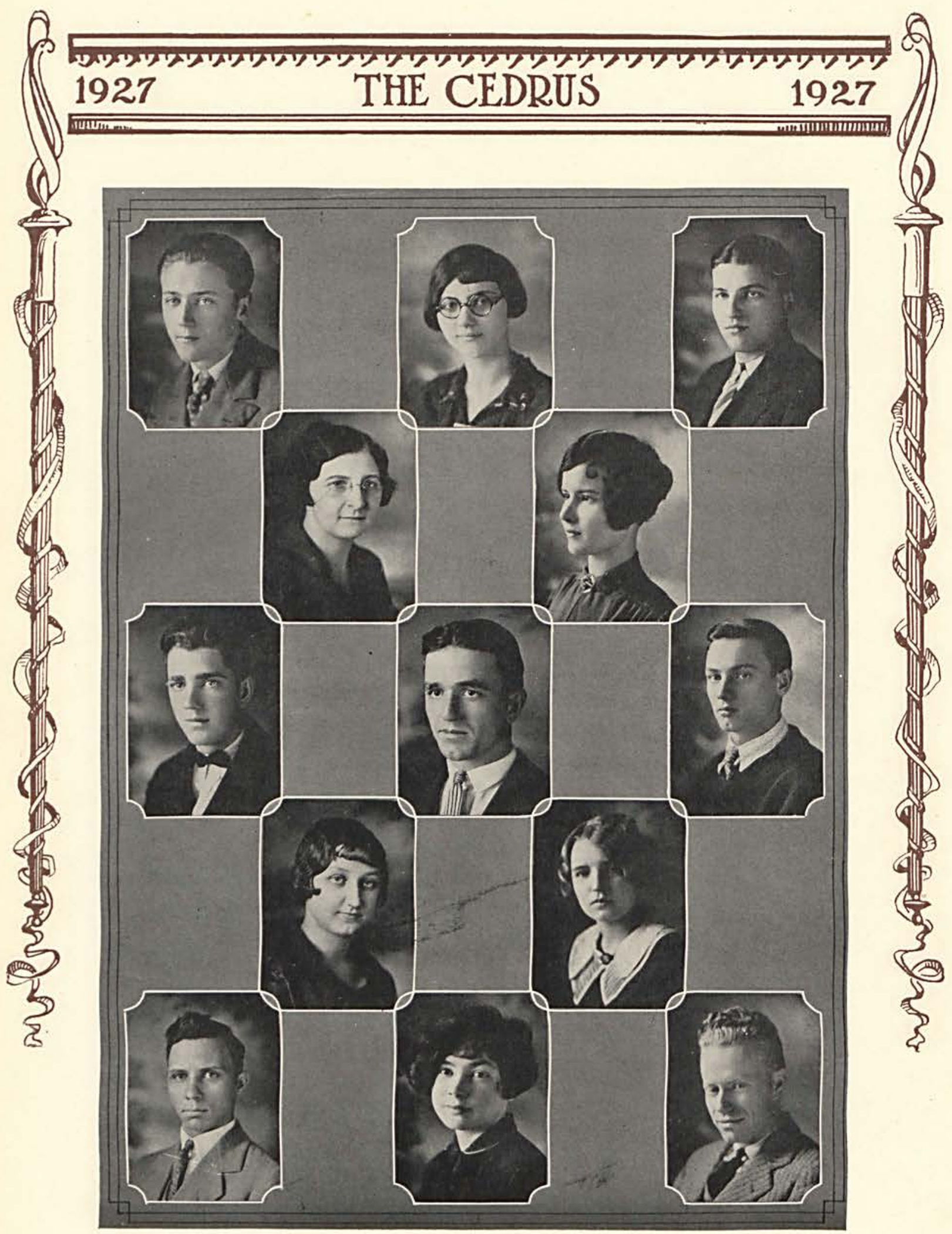

FRESHMEN 


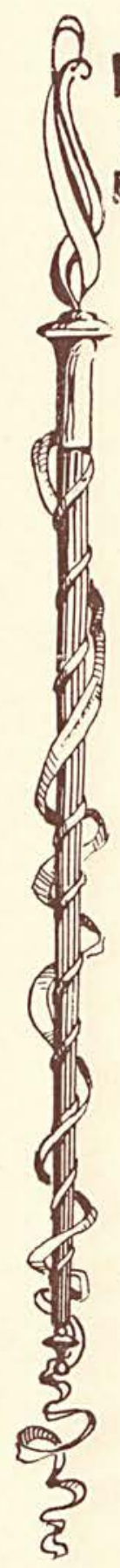

1927 THE CEDRUS

During the year of 1926-27, the Greene County Normal has been under the efficient direction of Miss Edna Howland, who, for the past eleven years, has been one of the foremost of the Ohio County Directors. She has been affiliated with the Summer Schools of Wilmington and Muskingum Colleges.

Other members of the Normal Staff are: Mrs. Alice M. Borst, Director of the Departments of Geography and Hygiene; Mrs. Walter Corry, Director of Music; Dr. W. R. McChesney, President of Cedarville College; and Professor H. H. Smith, Head of the Department of Education of the College.

The Class of 1926-27 is the largest in the history of the Greene County Normal. It is composed of five men and twenty-five women, representing Warren, Clark, Fayette, Butler, Madison, Pickaway, and Green Counties.

The Greene County Normal has an advantage in being associated with the College. The students have the opportunity of taking part in regular college activities; such as, the Y. W. C. A., the literary societies, and college athletics. The present class, in availing themselves of these opportunities, has been represented on the college teams, and, among the girls, has had a one-hundred per-cent membership in the Y. W. C. A.

On the evening of April 13 the Two-Year and County Normals, assisted by students of the College, staged an Indian operetta, "Lelawala", which forcibly demonstrated the musical ability of the group. The operetta was directed by Mrs. Corry.

From the very opening day the Normal has proved itself valuable. Much credit is due Miss Howland and her co-workers for the splendid co-operation with the College students and faculty. 


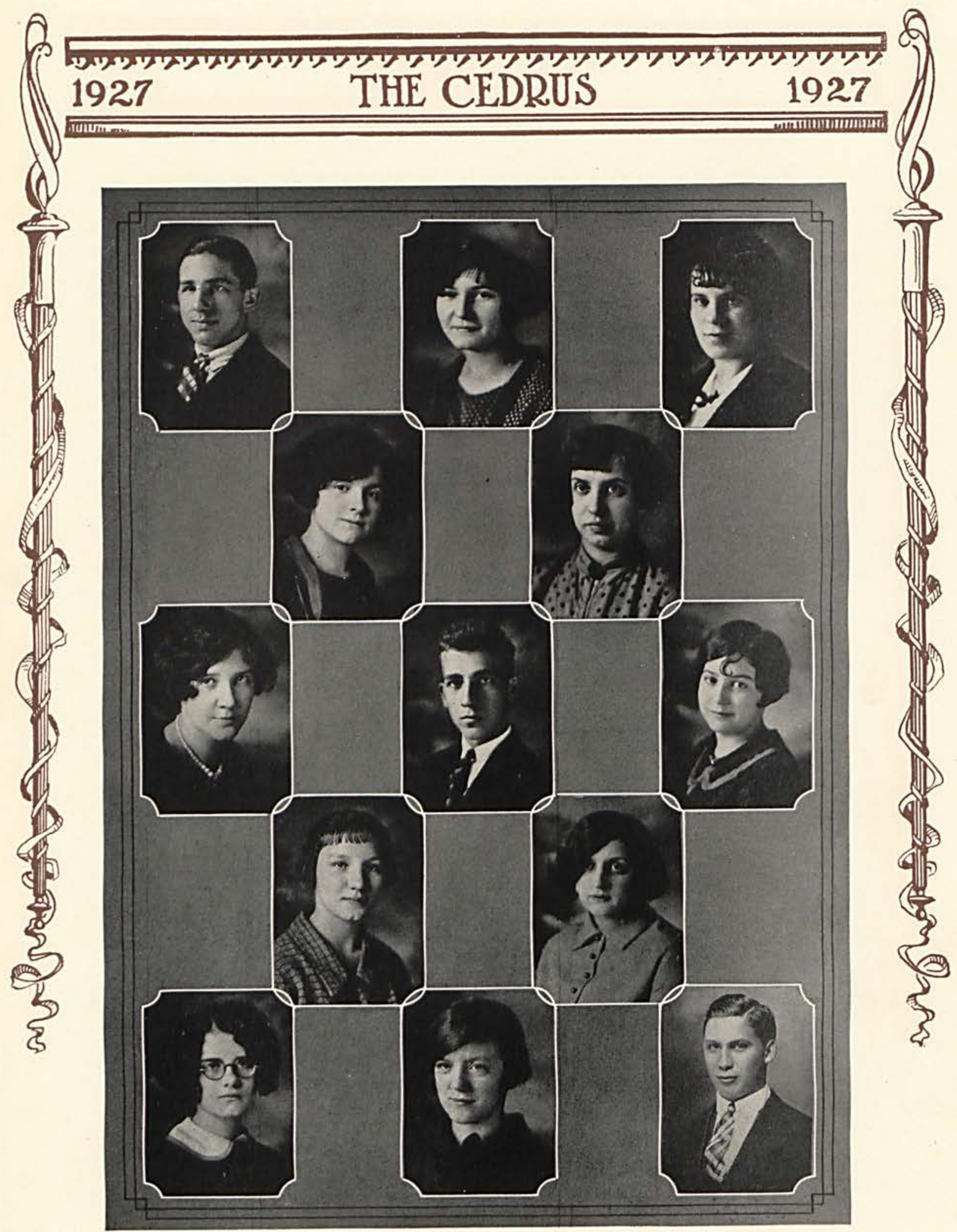

GREENE COUNTY NORMAL 


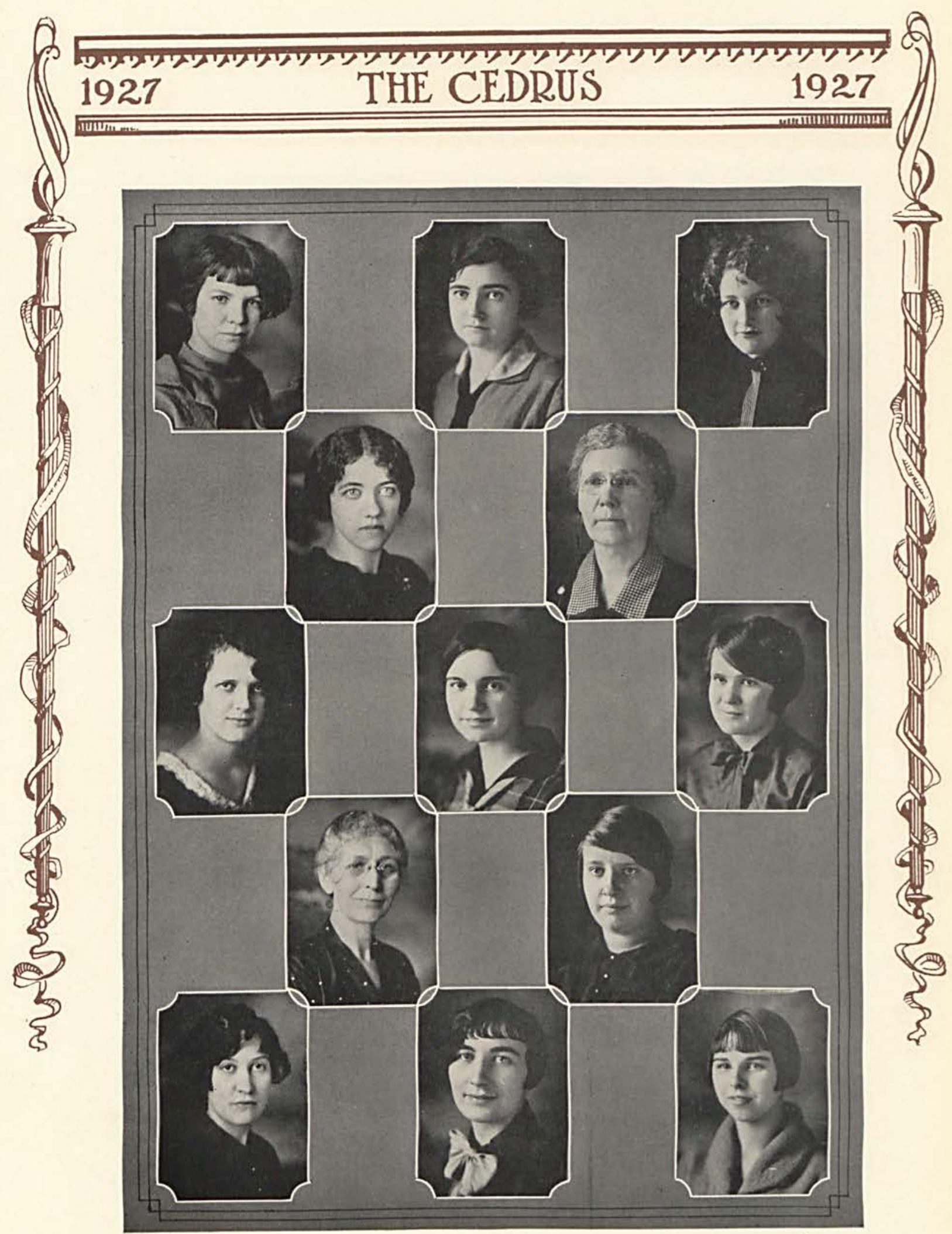

GREENE COUNTY NORMAL 


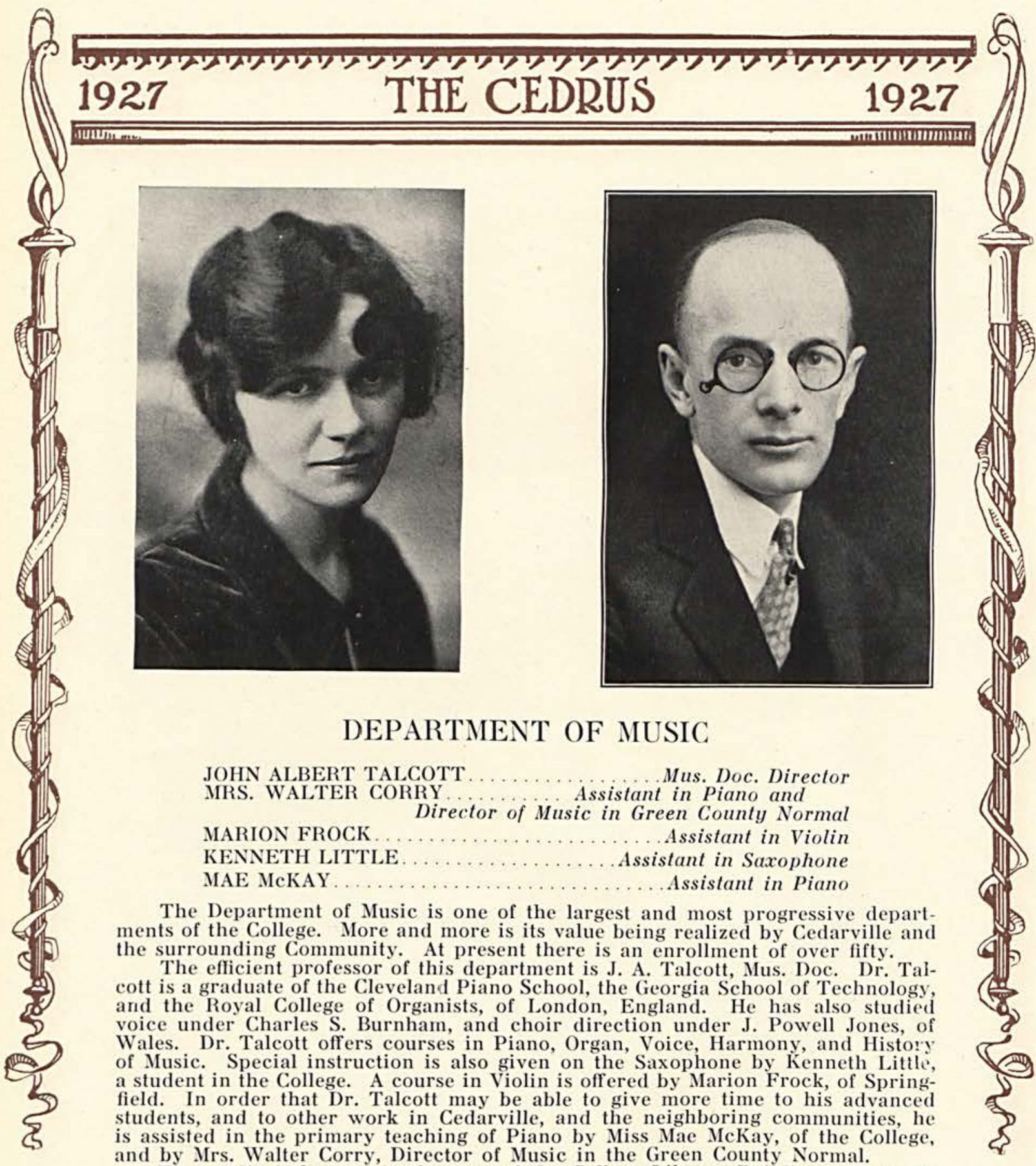

The studio is located in the rear of the College Library Building. Here the instruction in music is given privately in thirty- or forty-minute periods. All students are expected to appear in a public recital, usually given during Commencement Week. In addition, concerts are often given by the advanced students at the close of the Fall Term. When the required work has been completed, the pupil receives a diploma of graduation from the department. The College encourages work in music by allowing eight hours as electives for the A.B. degree.

Most of the pupils are studying music merely for their own enjoyment. Keeping this in mind, the department endeavors to ground all students in the technique of music, and to instil real musical interpretation; it endeavors to train students to receive the inspiration that comes from music, and the kindred arts, and to be able to appreciate the classical gems, and the masters in music. 


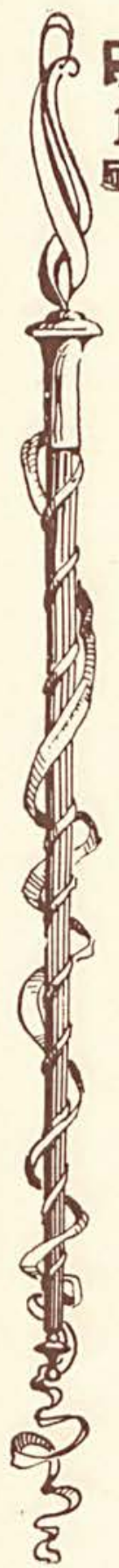

\author{
"LELAWALA" \\ Given by the \\ GREENE COUNTY NORMAL
}

\title{
CAST OF CHARACTERS
}

WO-KO-MIS (Great Heart) Chief of the Oniahgahrahs KLO-LO-WAR (The Singer) His son .................... Laurence McLean LE-LA-WA-LA (Falling Waters) his daughter; Maid of Niagara ....... Elsie Hawke MAR-PEE-TO-PAH (Four Skies) Medicine-man ............... Kenneth Retallick HIN-TO-LA (Blue Hair) Grandmother of Lelawala . . . . . . . . . . . . Mrs. Retallick SO-WAN-AS (South Wind) Lover of Lelawala . . . . . . . . . . . . Robert Turnbull SHUN-GE-LA (The Fox) Rejected lover of Lelawala ... . . . . . . Wendall Graham WA-COO-TAY (The Shooter) An Oniahgahrah brave............. Earl Pummell WAM-BE-BE (The Eagle) An Oniahgahrah brave............... Orin Turner WAN-YE-CA (The Firefly) A romantic widow . . . . . . . . . . . . . Lorine Creed NA-PA-NEE (The Brook) Who loves Klolowar . . . . . . . . . . . Nedra Wilson EAGLE EYE - A famous scout . . . . . . . . . . . . . . . . Robert Bratton

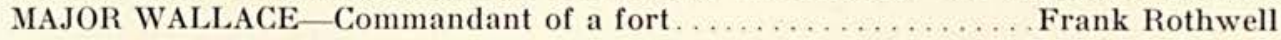
MABEL - His daughter . . . . . . . . . . . . . . . . . Kathryn Hughes CAPT. BLISS - Lover of Mabel . . . . . . . . . . . . . . . . Larry McLean CLARINDA BOND - Who admires the Sergeant . . . . . . . . . . . Gladys McCoy SERGEANT BILKS - Who admires himself . . . . . . . . . . . . . Ward Creswell LORD TATLER - Who admires witticisms . . . . . . . . . . . . . Hazel Ary

CHORUS-Indian hunters; Soldiers; Maidens.

TIME-1761.

\section{SYNOPSIS}

ACT I. Scenes 1 and 2. Indian village on bank of Niagara River near the falls. Morning and afternoon.

(Two days are supposed to have elapsed between Scenes 1 and 2.)

ACT II. Scene 1. Indian camp in forest glade. Night.

Scene 2. Same as Act I. Afternoon and evening.

ACT III. Same as previous Act. The next morning.

(One week is supposed to elapse between Acts I and II, and between each of the scenes of Act II.)

The above operetta was given April 13 under the capable and efficient instruction of Mrs. Corry, Instructor of Music in the Greene County Normal. A large audience witnessed the performance, which was very successful. 

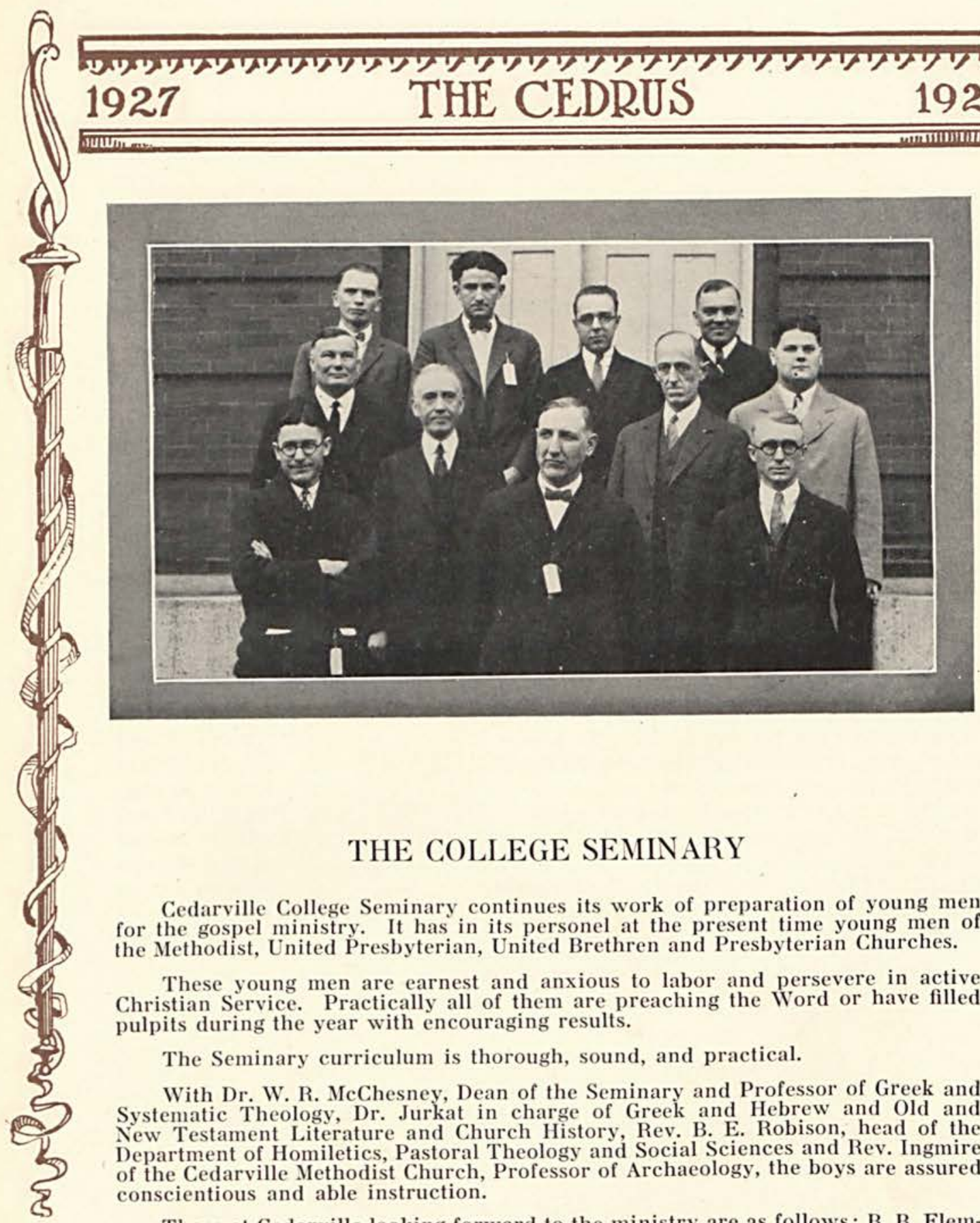

\section{THE COLLEGE SEMINARY}

Cedarville College Seminary continues its work of preparation of young men for the gospel ministry. It has in its personel at the present time young men of the Methodist, United Presbyterian, United Brethren and Presbyterian Churches.

These young men are earnest and anxious to labor and persevere in active Christian Service. Practically all of them are preaching the Word or have filled pulpits during the year with encouraging results.

The Seminary curriculum is thorough, sound, and practical.

With Dr. W. R. McChesney, Dean of the Seminary and Professor of Greek and Systematic Theology, Dr. Jurkat in charge of Greek and Hebrew and Old and New Testament Literature and Church History, Rev. B. E. Robison, head of the Department of Homiletics, Pastoral Theology and Social Sciences and Rev. Ingmire of the Cedarville Methodist Church, Professor of Archaeology, the boys are assured conscientious and able instruction.

Those at Cedarville looking forward to the ministry are as follows: B. B. Fleming, Osborne, Ohio; M. L. Massie, New Jasper, Ohio; Rev. D. D. Dutton, Springfield, Ohio; Fred Wills, Springfield, Ohio; Edward Wones, Springfield, Ohio; Clair McNeil, St. Petersburg, Fla.; Marvin L. Williams, Cedarville, Ohio; Calvin T. Weimer, Leetonia, Ohio. 


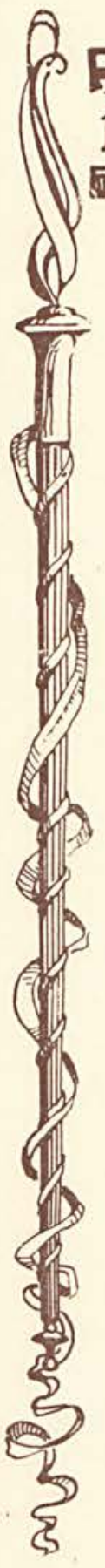

\section{STUDENTS NOT APPEARING IN PHOTOGRAPHS}

FRESHMEN

\begin{abstract}
HELEN FINNEY
CAMMIE GORMLEY

KATE MORGAN

ROSCOE FUDGE
\end{abstract}

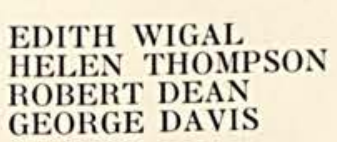

GEORGE DAVIS

DAY KENNEDY

VERNA BOASE

\section{MARY BEAM \\ CARL SHANKS}

Cedarville, Ohio

Cedarville, Ohio Plattsburg, Ohio Xenia, Ohio

\section{SOPHOMORES}

Cedarville, Ohio Cedarville, Ohio Cedarville, Ohio Jerusalem, Ohio

\section{JUNIORS}

Coulterville, III. Cedarville, Ohio

\section{SENIORS}

$$
\begin{array}{r}
\text { Xenia, Ohio } \\
\text { Port William, Ohio }
\end{array}
$$

FIRST YEAR NORMAL

ELSIE HAWKE

MARJORIE HUBBLE

Waynesville, Ohio

Waynesville, Ohio

SECOND YEAR NORMAL

VESTA HALSTEAD

Cedarville, Ohio

SPECIAL STUDENT

HELEN CARTER

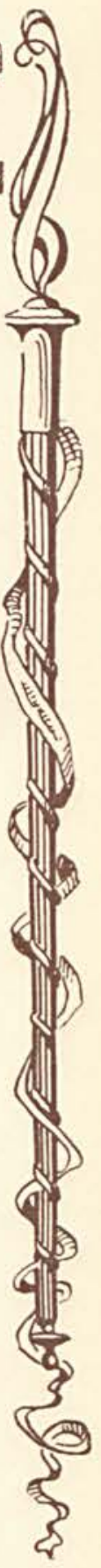

1927 


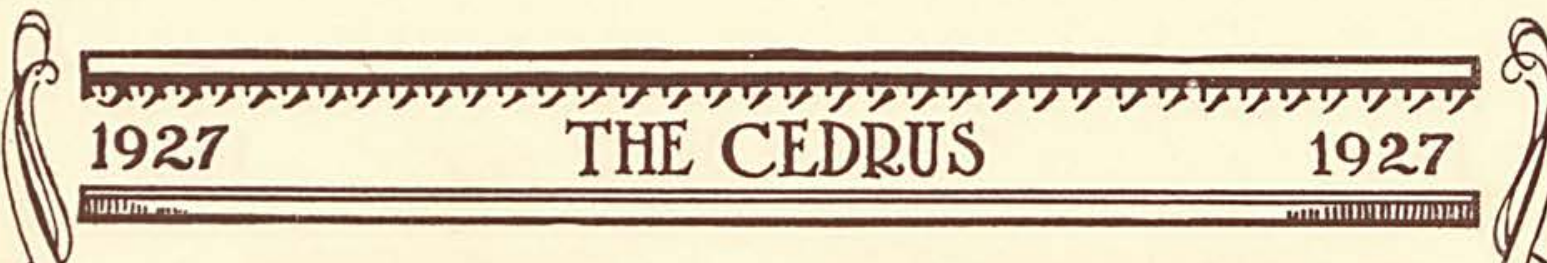

(d)
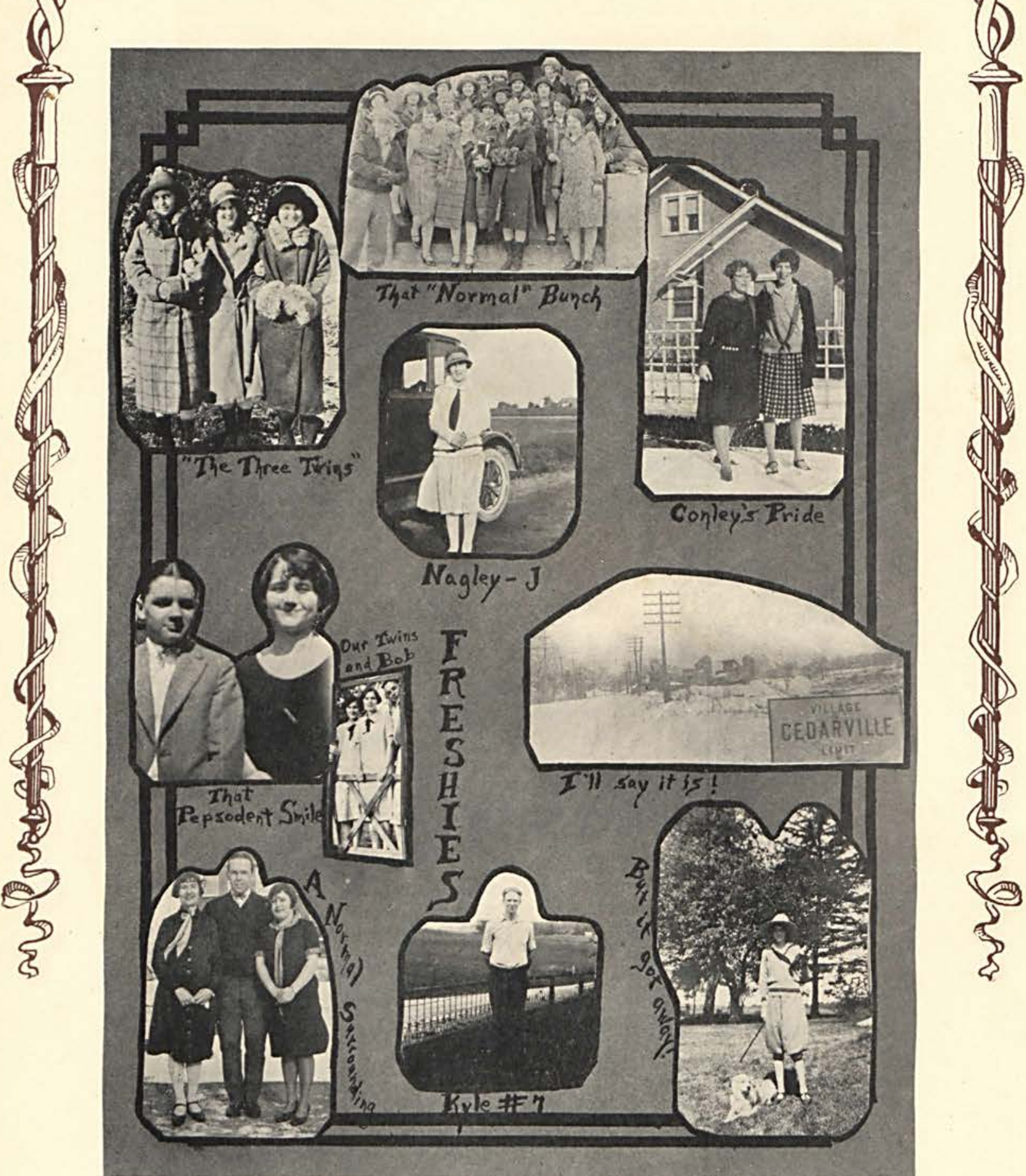

毁

,

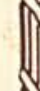

(4)

है 


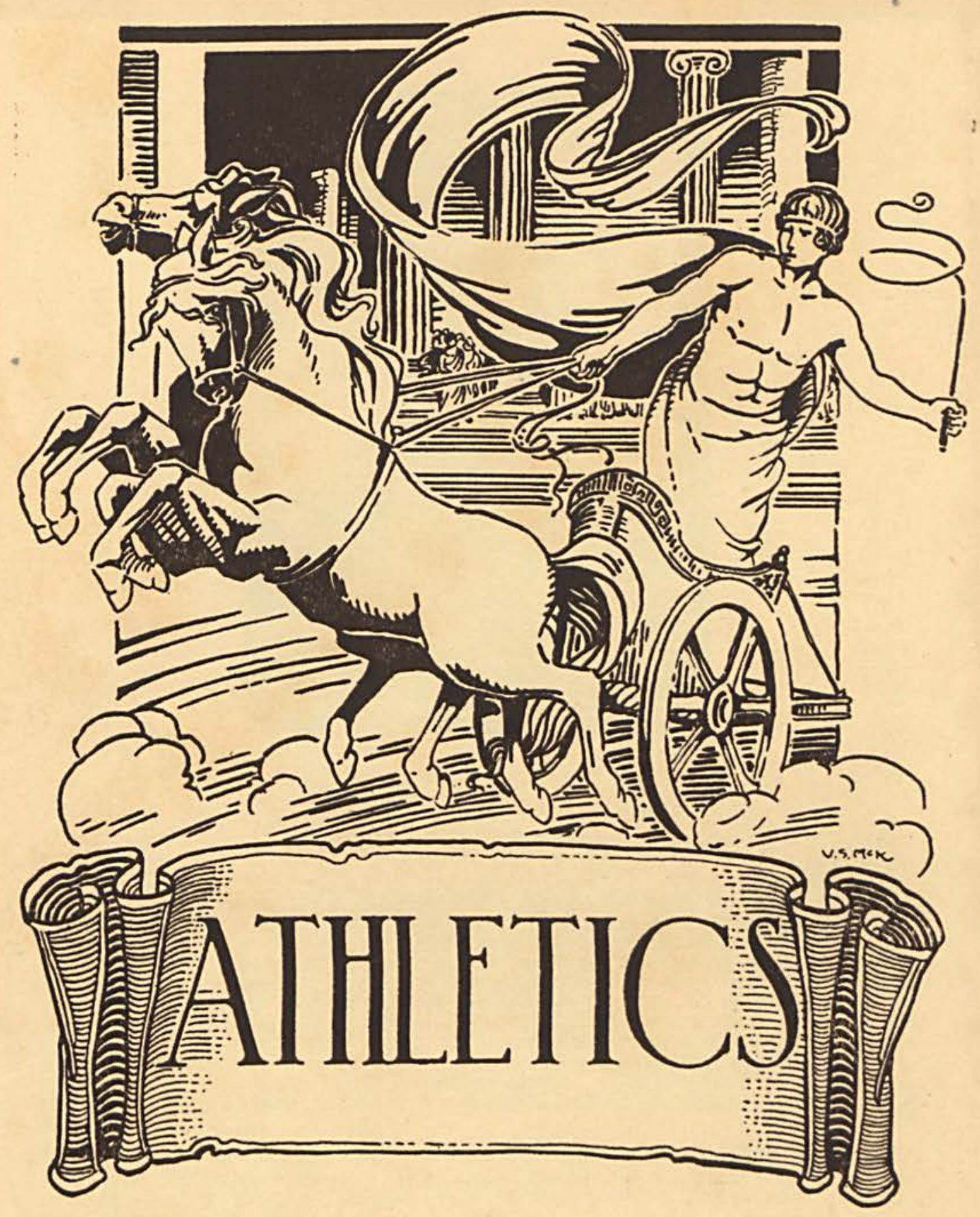




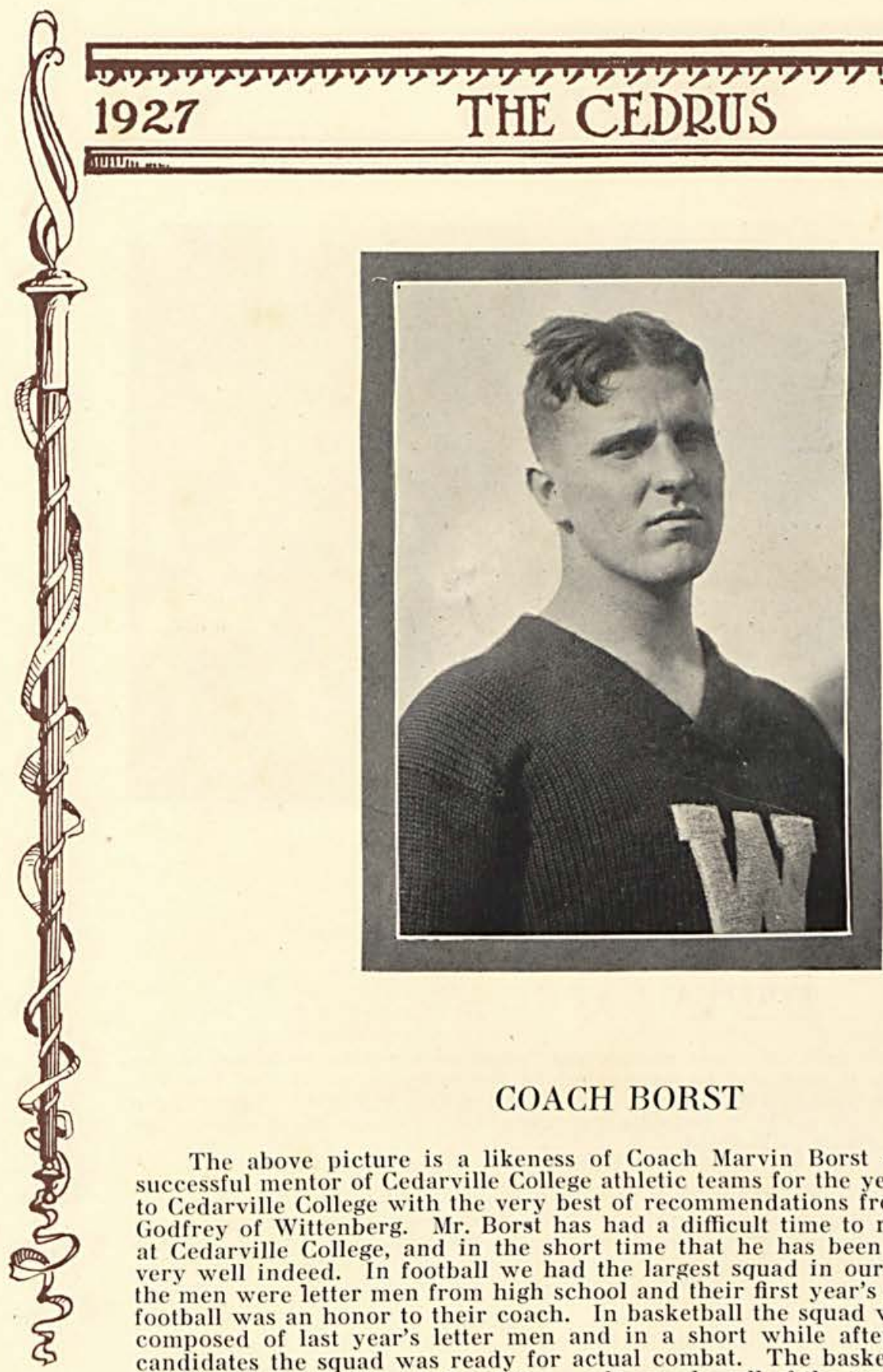

\section{COACH BORST}

The above picture is a likeness of Coach Marvin Borst who has been the successful mentor of Cedarville College athletic teams for the year 1926-27, coming to Cedarville College with the very best of recommendations from his own Coach, Godfrey of Wittenberg. Mr. Borst has had a difficult time to reorganize athletics at Cedarville College, and in the short time that he has been here he has done very well indeed. In football we had the largest squad in our history. Many of the men were letter men from high school and their first year's showing in college football was an honor to their coach. In basketball the squad was almost entirely composed of last year's letter men and in a short while after the first call for candidates the squad was ready for actual combat. The basketball schedule was the heaviest ever attempted and the results speak well of the training they received from Mr. Borst.

Under the careful and skillful tutelage of Coach Borst the athletic fame of Cedarville College has grown by leaps and bounds and we predict in the years to come under his direction Cedarville will once more be recognized as the leading small College in the state. 

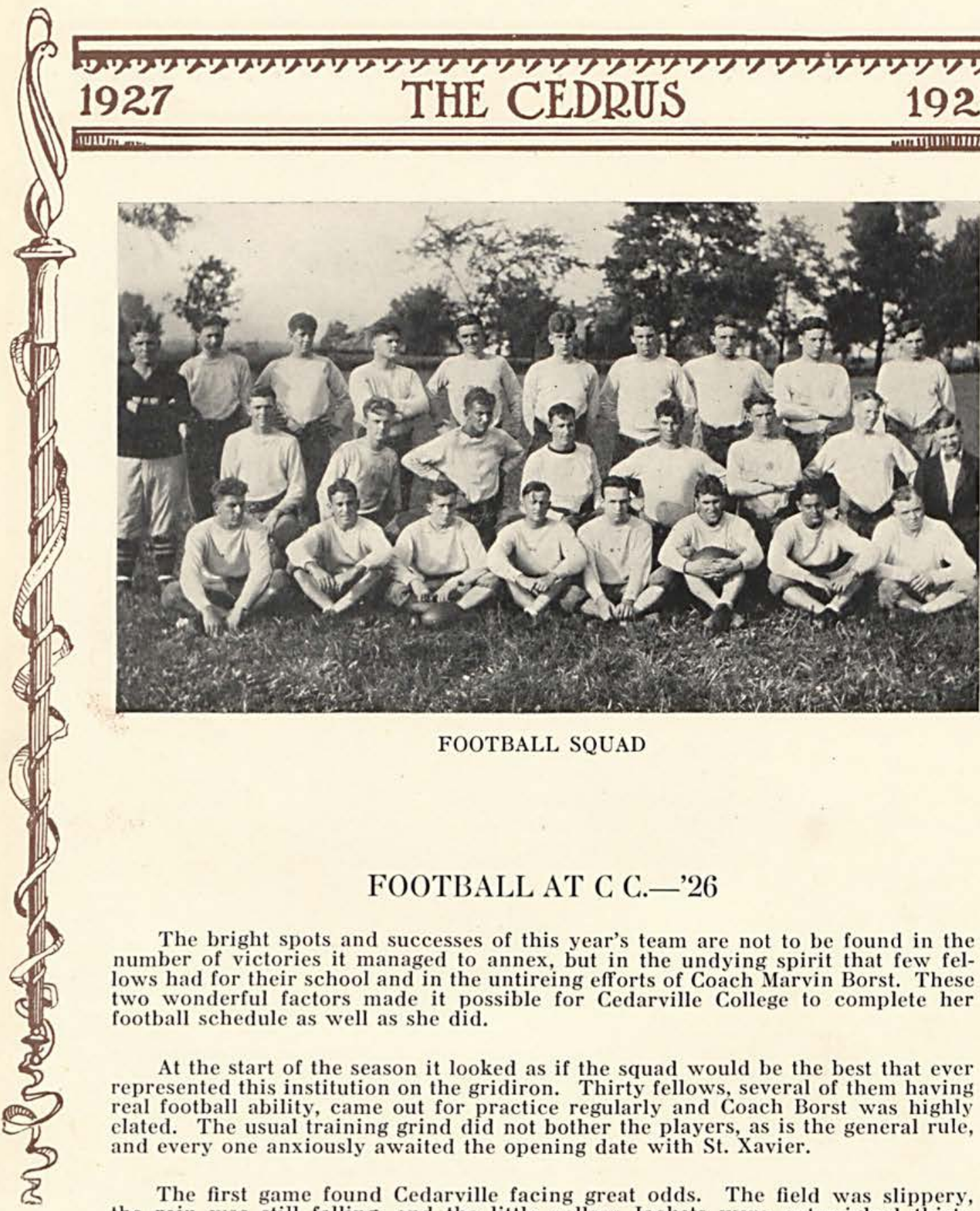

FOOTBALL SQUAD

FOOTBALL AT C C.-’26

The bright spots and successes of this year's team are not to be found in the number of victories it managed to annex, but in the undying spirit that few fellows had for their school and in the untireing efforts of Coach Marvin Borst. These two wonderful factors made it possible for Cedarville College to complete her football schedule as well as she did.

At the start of the season it looked as if the squad would be the best that ever represented this institution on the gridiron. Thirty fellows, several of them having real football ability, came out for practice regularly and Coach Borst was highly elated. The usual training grind did not bother the players, as is the general rule, and every one anxiously awaited the opening date with St. Xavier.

The first game found Cedarville facing great odds. The field was slippery, the rain was still falling, and the little yellow Jackets were outweighed thirty pounds to the man. Cedarville battled hard and their fine spirit was ever present, but the weight and height of the Musketeers were not to be denied. Therefore the long end of a 54 to 0 score remained in Cincinnati after the game.

The following week end was spent with the Quakers at Earlham. The Yellow Jackets managed to use their sting a couple of times but they could not cope with the Hoosier aerial attack. Cedarville rallied in the last quarter with driving line plays but it was too late. Earlham had the game won 23 to 13 . 

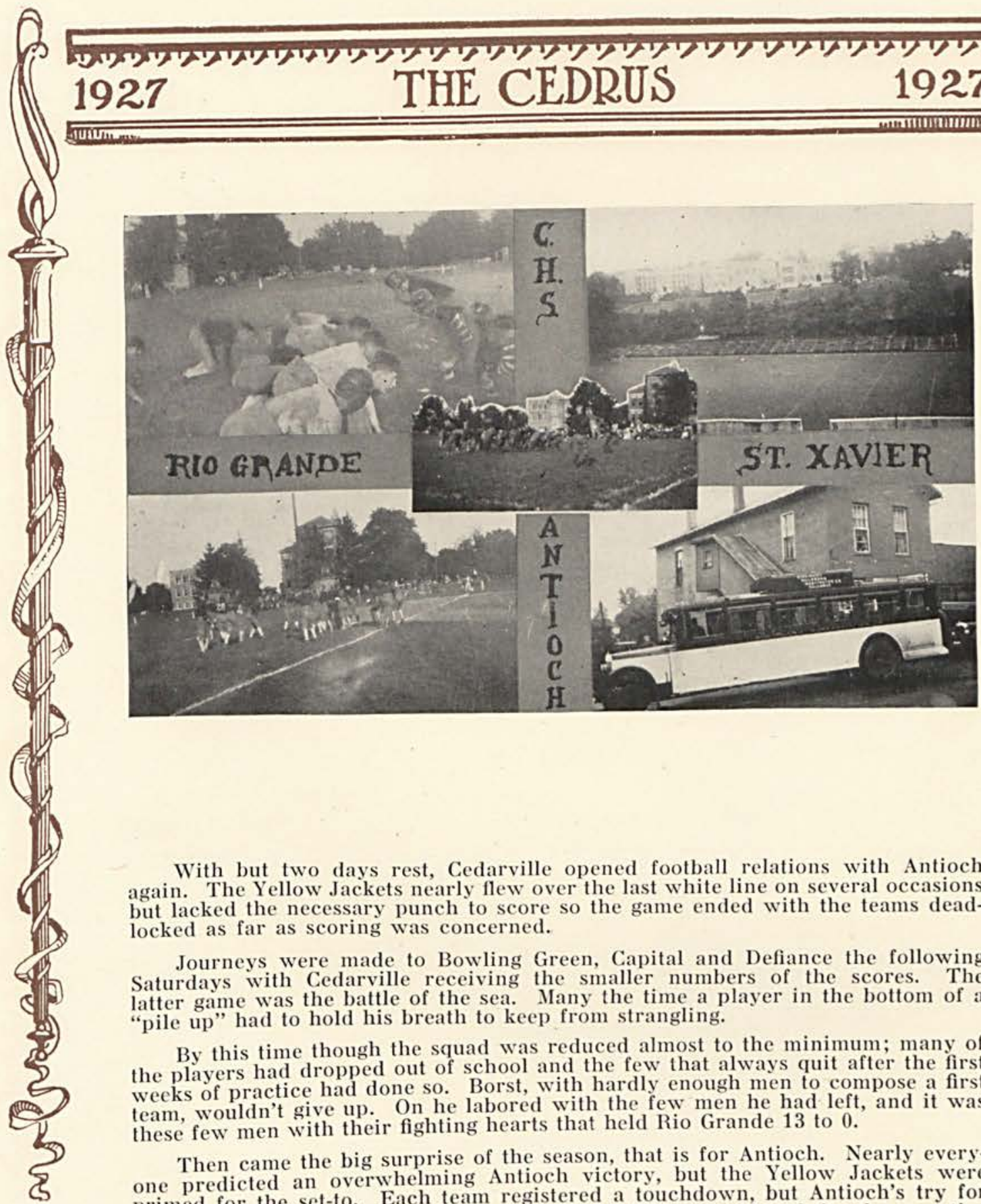

With but two days rest, Cedarville opened football relations with Antioch again. The Yellow Jackets nearly flew over the last white line on several occasions but lacked the necessary punch to score so the game ended with the teams deadlocked as far as scoring was concerned.

Journeys were made to Bowling Green, Capital and Defiance the following Saturdays with Cedarville receiving the smaller numbers of the scores. The latter game was the battle of the sea. Many the time a player in the bottom of a "pile up" had to hold his breath to keep from strangling.

By this time though the squad was reduced almost to the minimum; many of the players had dropped out of school and the few that always quit after the first the players had dropped our so weeks of practice had done so. Borst, with the few men he had left, and it was team, wouldn't give up. fir finting hearts that held Rio Grande 13 to 0.

these few men with their fighting hearts that held Rio crance

Then came the big surprise of the season, that is for Antioch. Nearly everyone predicted an overwhelming Antioch victory, but the but Antioch's try for primed for the set-to. Each team regle Cedarvill's was placed in the negative point a

In the last game it was just a case of too much Bluffton quarterback; he was one of the best open field runners that has ever performed on a local gridiron.

Now we have reached the end of our journey. The peace pipe is passed on to future teams and we hope that their success may be termed in victories and fighting spirit combined. -D. M. 
PROF. M. L. FRASIER

Chairman

PROF. F. A. JURKAT

Treasurer

PROF F. A. BORST

Coach

FOOTBALL

Manager .

HARVEY AULD

Asst. Manager

Captain JAMES BEAM

PAUL BROWN
BASEBALL

Manager

JAMES LEMONS Asst. Manager. . ROBERT THOMPSON Captain PAUL ORR

\section{BASKET BALL}

\begin{tabular}{|c|c|c|}
\hline \multicolumn{2}{|r|}{ Girls } & Boys \\
\hline Manager & . IRENE SHANNON & Manager......... HERMAN LeMAR \\
\hline Captain & LUCILE RITENOUR & Asst. Manager........ K. RETALLICK \\
\hline
\end{tabular}

Cedarville College opened its Baseball Season with a complete victory over Wilberforce University. The future of this sport is very hopeful.

Clarence Lyon and David Adair were entered into Ohio Relays on April 26.

The following will appear on the tennis team: Little, Rockhold, Brown, Creswell, and Barlow. The College team will meet: Dayton U., Wilmington, Wittenburg, and Antioch in contests.

Plans are being made to meet Antioch and Dayton U., and probably other colleges in swimming contests. Jacobs, Thompson, Lyons, Adair, Evans and Orr will be out for this activity.

The following is the lineup for baseball: Pitching Staff, Nagley, Turner and McLean; Catchers, Adair, Rothwell; Infield, Orr, Evans, Lyons, Turner, Kenney; Outfield, Armstrong, Huston, Tanner, and Dean. 


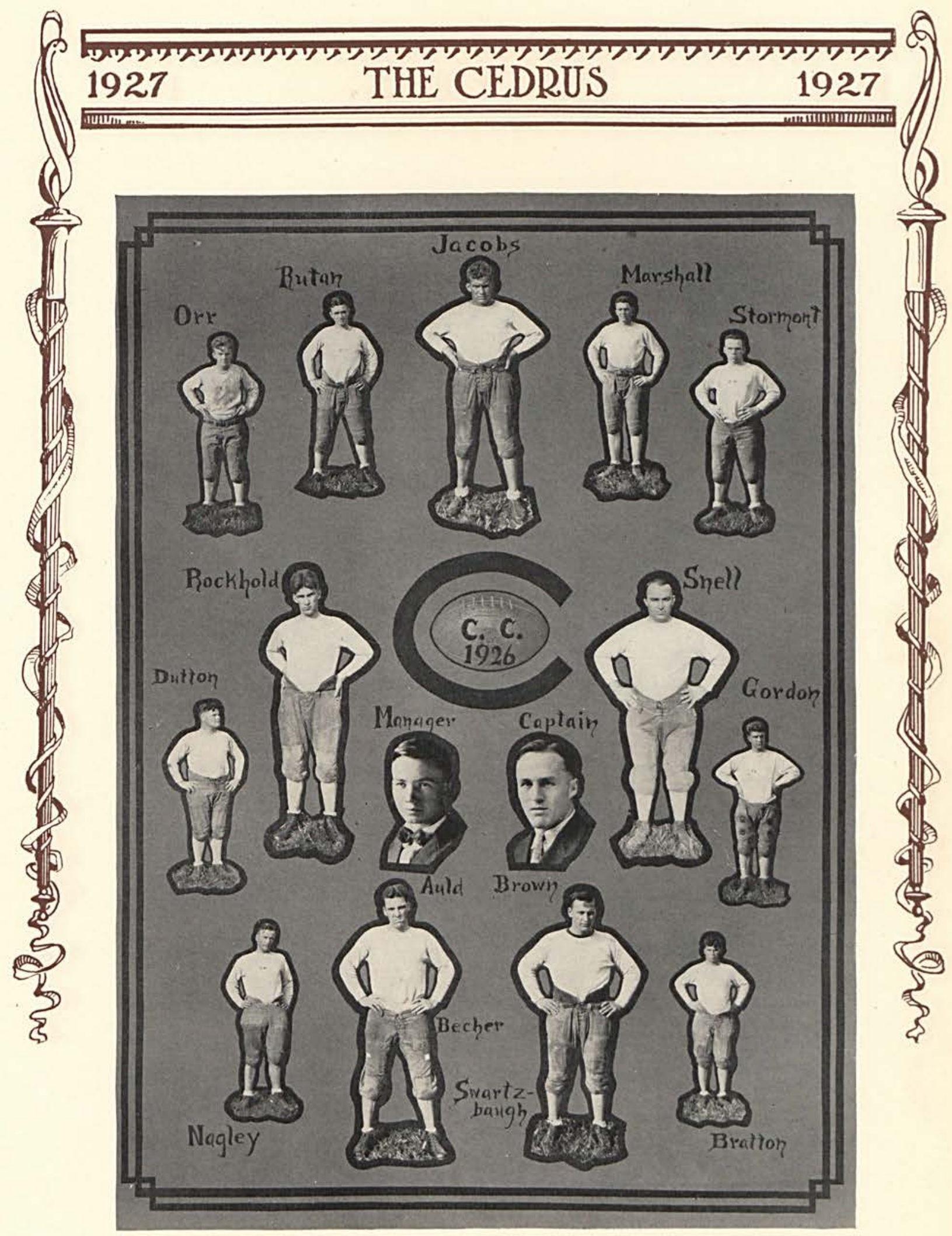



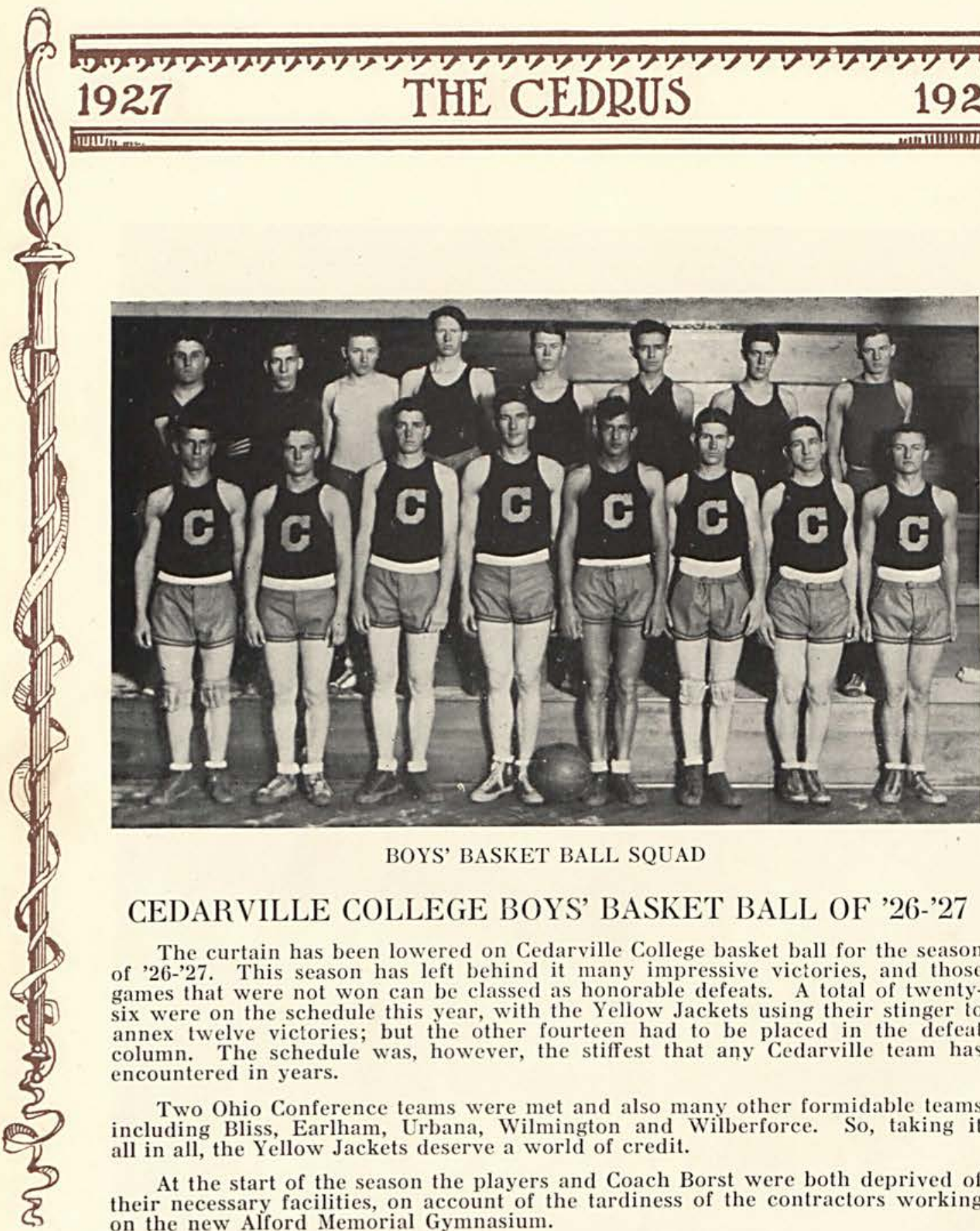

BOYS’ BASKET BALL SQUAD

\section{CEDARVILLE COLLEGE BOYS' BASKET BALL OF '26-'27}

The curtain has been lowered on Cedarville College basket ball for the season of '26-'27. This season has left behind it many impressive victories, and those games that were not won can be classed as honorable defeats. A total of twentysix were on the schedule this year, with the Yellow Jackets using their stinger to annex twelve victories; but the other fourteen had to be placed in the defeat column. The schedule was, however, the stiffest that any Cedarville team has encountered in years.

Two Ohio Conference teams were met and also many other formidable teams including Bliss, Earlham, Urbana, Wilmington and Wilberforce. So, taking it all in all, the Yellow Jackets deserve a world of credit.

At the start of the season the players and Coach Borst were both deprived of their necessary facilities, on account of the tardiness of the contractors working on the new Alford Memorial Gymnasium.

The prospects were bright from the start. Several veterans were available and a likely crop of new material was on hand from which to pick. There was Captain Little whose guarding ability was of the highest: Rockhold, the "Grand old Man" of Cedarville College basket ball, who had held down the back guard position for three years; Nagley, diminutive southpaw forward and veteran of two campaigns. Gordon and Orr had well exhibited their skill the year previous, as had Jacobs and Evans. 
The first two weeks of practice had to be held in the High School gym, and owing to the large number present for the first practices the place was rather crowded, making the workouts very difficult. Coach Borst had to make the best of what he had and condition his men as best he could under the circumstances, for the nearing initial game with Earlham College at Richmond, Ind. Captain Little had been forced to quit practicing due to a conflict with his work and Evans had not yet reported for practice. These two factors made it equally harder to get things running smoothly.

But Coach Borst with eight men journeyed to Earlham for the initial contest with the Quakers. The starting lineup for the first game consisted of Nagley and Orr at forwards, Jacobs at center, Gordon and McLean, a newcomer from Dayton, at guards. Cedarville outplayed Earlham until Orr wah banished from the game six minutes after the game started by the personal foul route; and with Orr went Cedarville's offensive attack. The Yellow Jackets managed to hold the Hoosiers the rest of the half, but Earlham came back strong in the last half to put Cedarville's first game of the season in the defeat column.

Then came the first game in the new Alford Memorial Gymnasium. The opposition happened to be furnished by our ancient rivals from Antioch. The Yellow Jackets were primed for the occasion, taking the floor with fighting hearts and blood in their eye, to secure a victory for Cedarville College in the game that opened athletic activities in the new gym. The Yellow Jackets flew into the Antiochians, stinging them at will, and emerged with an undoubted victory.

By this time Little had quit his job in order that he might play ball for his school and Evans had also reported for practice.

The next game found Coach Borst giving some of his new men a chance to show their wares. They fought hard but could not withstand the onslaught of the Urbana lads, so the "Old Reliables" were called into play to pull the game out of the fire in the closing minutes of the final half.

The annual trip to Wilmington was drawing closer and the boys practiced 
strenously for the encounter with the "Green Tornado", because it was a game that held a position all its own and Cedarville wanted to win this game above all others. But during the game whenever Cedarville managed to score a few points in rapid succession, by some strange co-incidence they always committed personals. By means of the penalties attached to these personals, Wilmington was able to maintain a slight lead throughout the contest.

During the Christmas vacation Cedarville displayed the best brand of basket ball that they had yet shown. In defeating Defiance the team worked with the ease of a well-oiled machine, Orr alone collecting enough points to defeat them. After the holidays the team decided to keep up the good work, so they copped a very impressive victory from the University of Dayton Flyers by a single point margin. This marked the third straight year that the Yellow Jackets have defeated the Irish in basket ball.

Wilberforce was then met, and for the first time defeated, by a team representing Cedarville College. Urbana and Findlay were then met and defeated, making a string of five victories.

Capital's great team of this year took it as their duty to stop the winning streak of the Borstites and did a neat job of it. Bernlor's left-hook shot just couldn't be stopped, and with some nice teamwork walloped our lads.

In the Home-Coming game the boys tried to outdo themselves, before the great crowd of Alumni and ex-students that had gathered to see them perform, by swamping Kent State Normal 25-9. Cedarville set up a defense that the up-state lads could not penetrate, and seemed able to score at will.

The Wilberforce game at home was by far the most exciting and best attended game of the year. Fans swarmed to every nook and corner of the gym and this bunch nearly shook down the walls with their continuous rooting. Wu Fang Ward and four other colored boys were too much for the Yellow Jackets that night, but the victory was undecided untıl the whistle ended the bitter struggle.

Earlham then came out of the west to display the fastest dribbling, shooting, and faking team that has played on a local court. Not being able to keep up with the speed of the Hoosiers, the boys lost their second game of the week. 


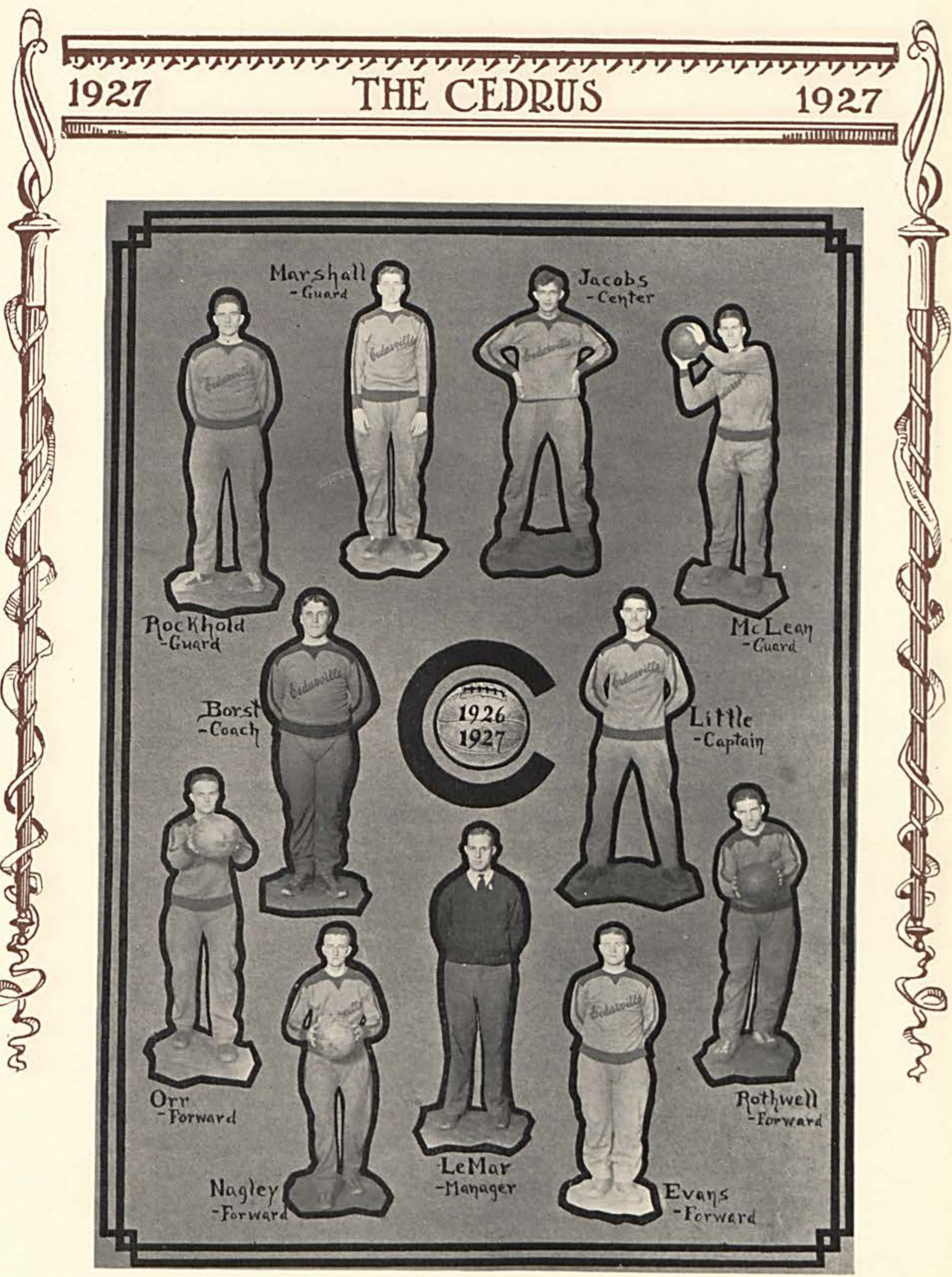


The northern road trip proved to be the disaster of the season as far as winning any games was concerned. Cedarville was doped to win at least two games, and was given an even break on the third. Some one "sure upset the dope bucket," because Findlay, Bluffton, and Kent State pushed their noses in the dust in three successive games.

But to atone for all their losses, they defeated “Jerry" Katherman's Capital quintet and procured the sweet revenge they have been seeking for years. Capital lost only three games this season, one of them being by Muskingum, Ohio Conference Champs, by one point. The win over them was the most impressive and well earned of the season. It well serves the purpose of a fitting climax to the '26-'27 history of Cedarville College inter-Collegiate basket ball.

The wonderful team from Bliss, which downed Ohio Wesleyan, hasn't been forgotten, and a majority of the players class them as the best team that they encountered this season. The Business College boys were too tall for the Orange and Blue, so the two games with them were placed in the honorable defeat column.

After the close of the regular collegiate schedule several games were booked with the leading professional teams of this section. The Delco-Light quintet from Dayton and the American Seeding Machine Co., team were met and disposed of in easy fashion; but the strong Dayton Troy-Fords bested our boys by a few points.

All the games of the past season have not been mentioned in detail, but the writer in his limited space has tried to give a brief resume of the important and most exciting games. 


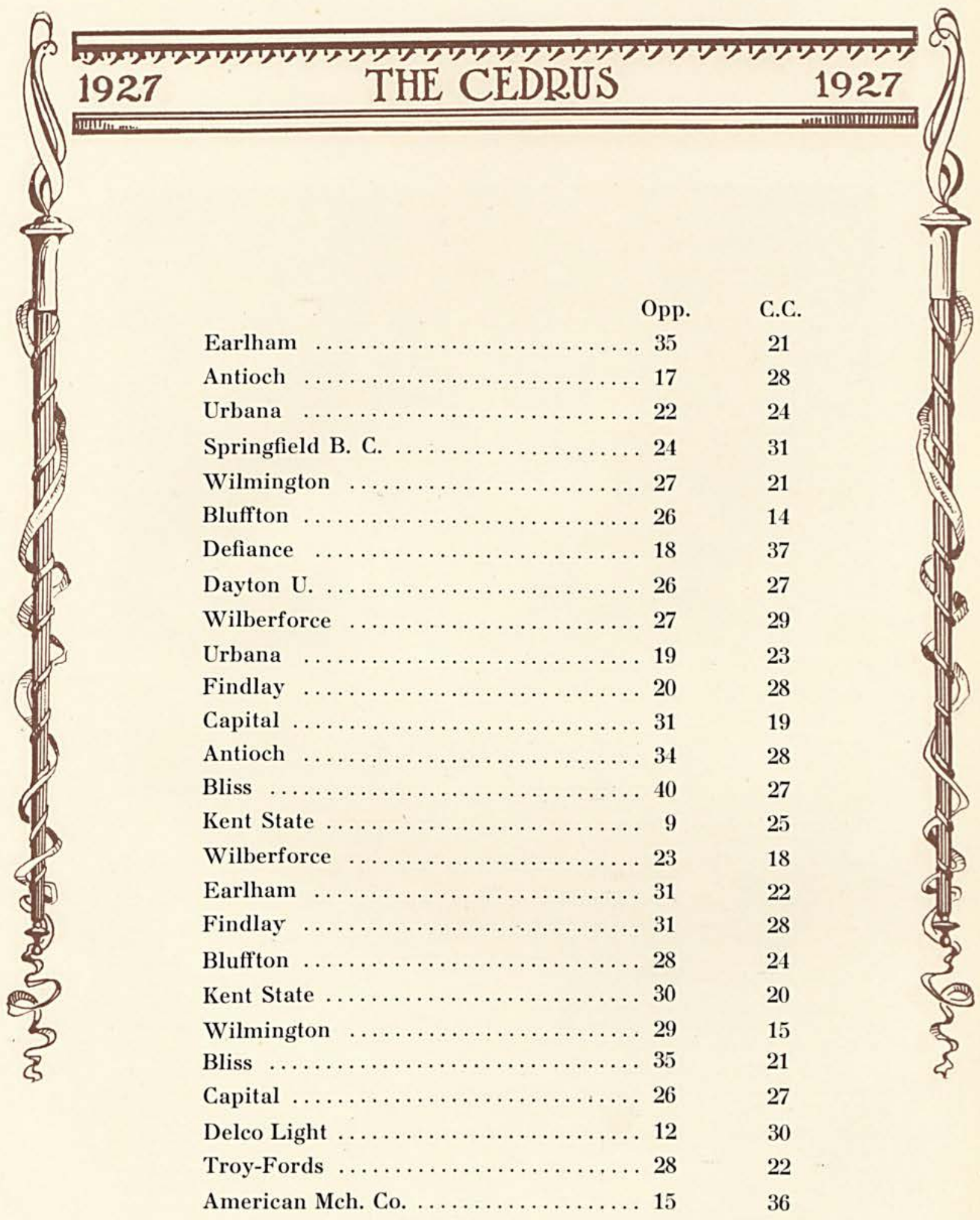




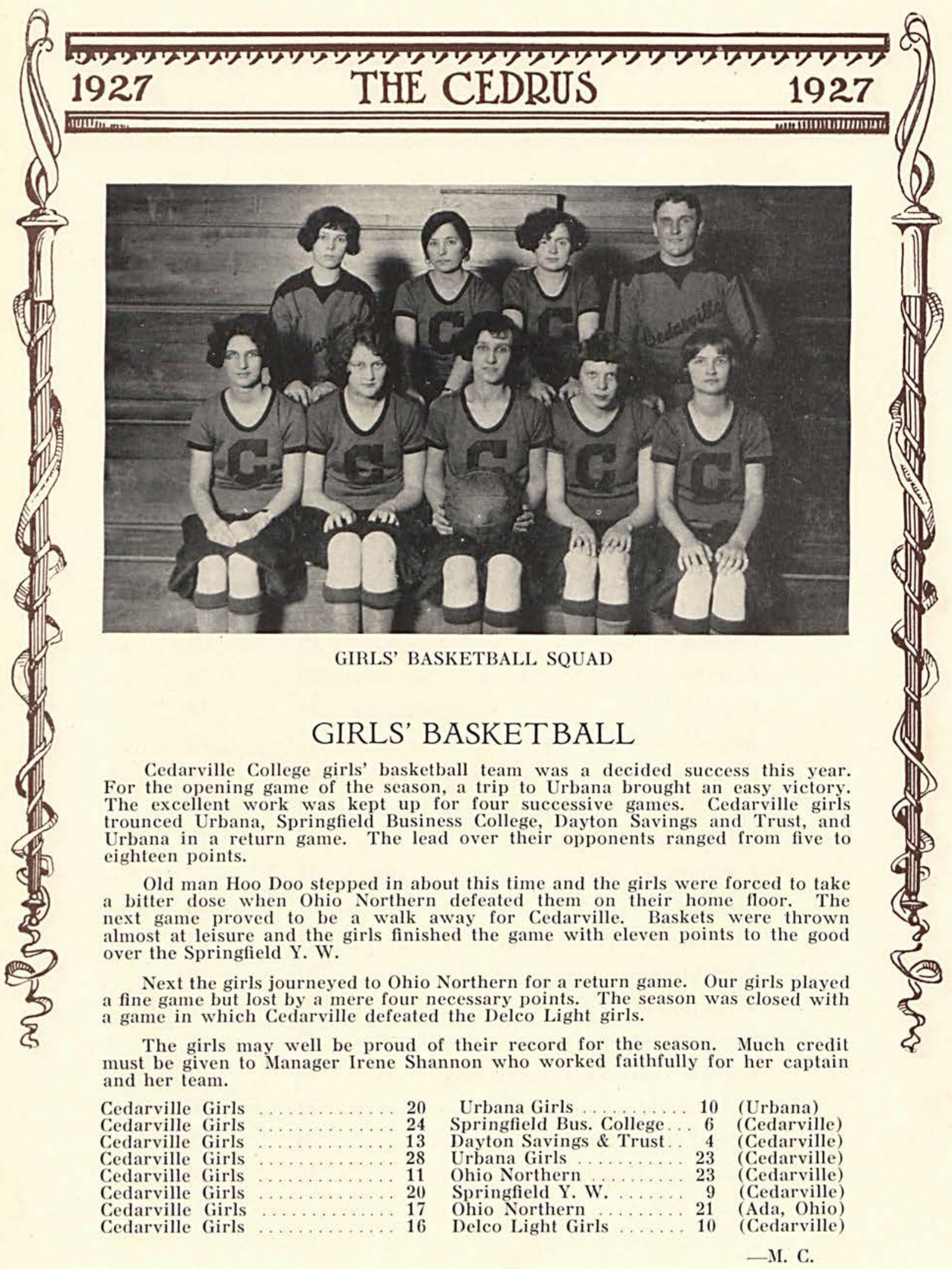




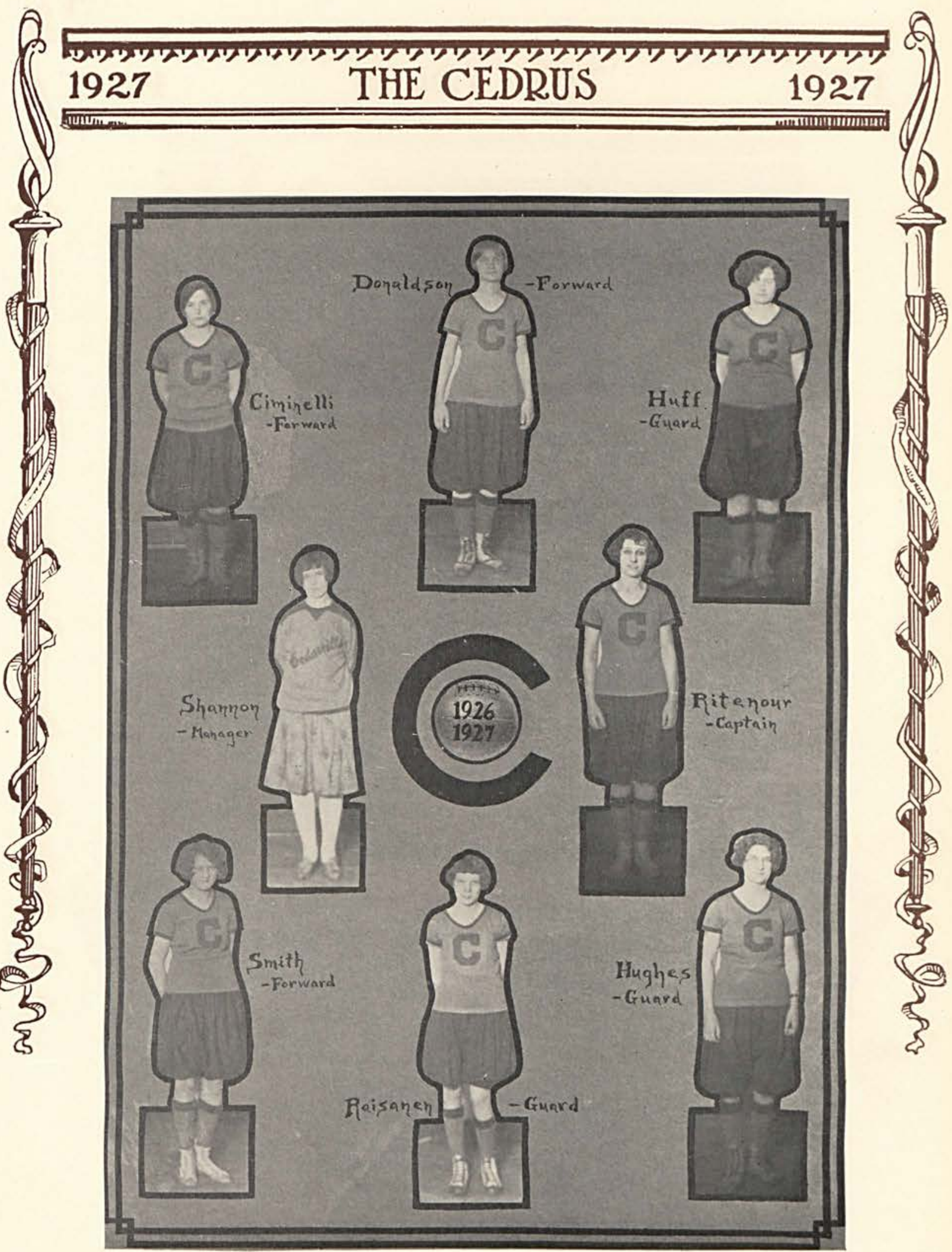




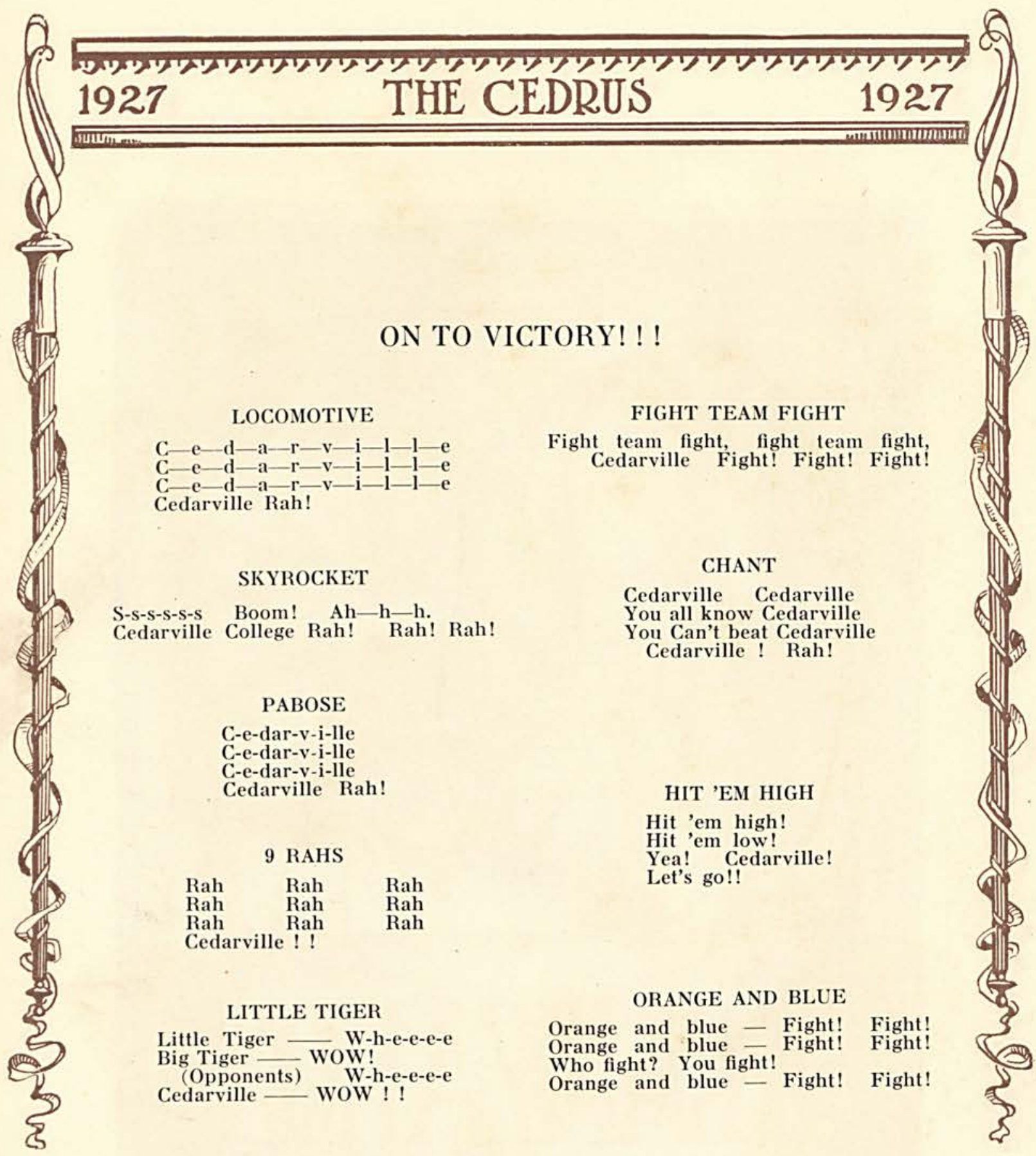




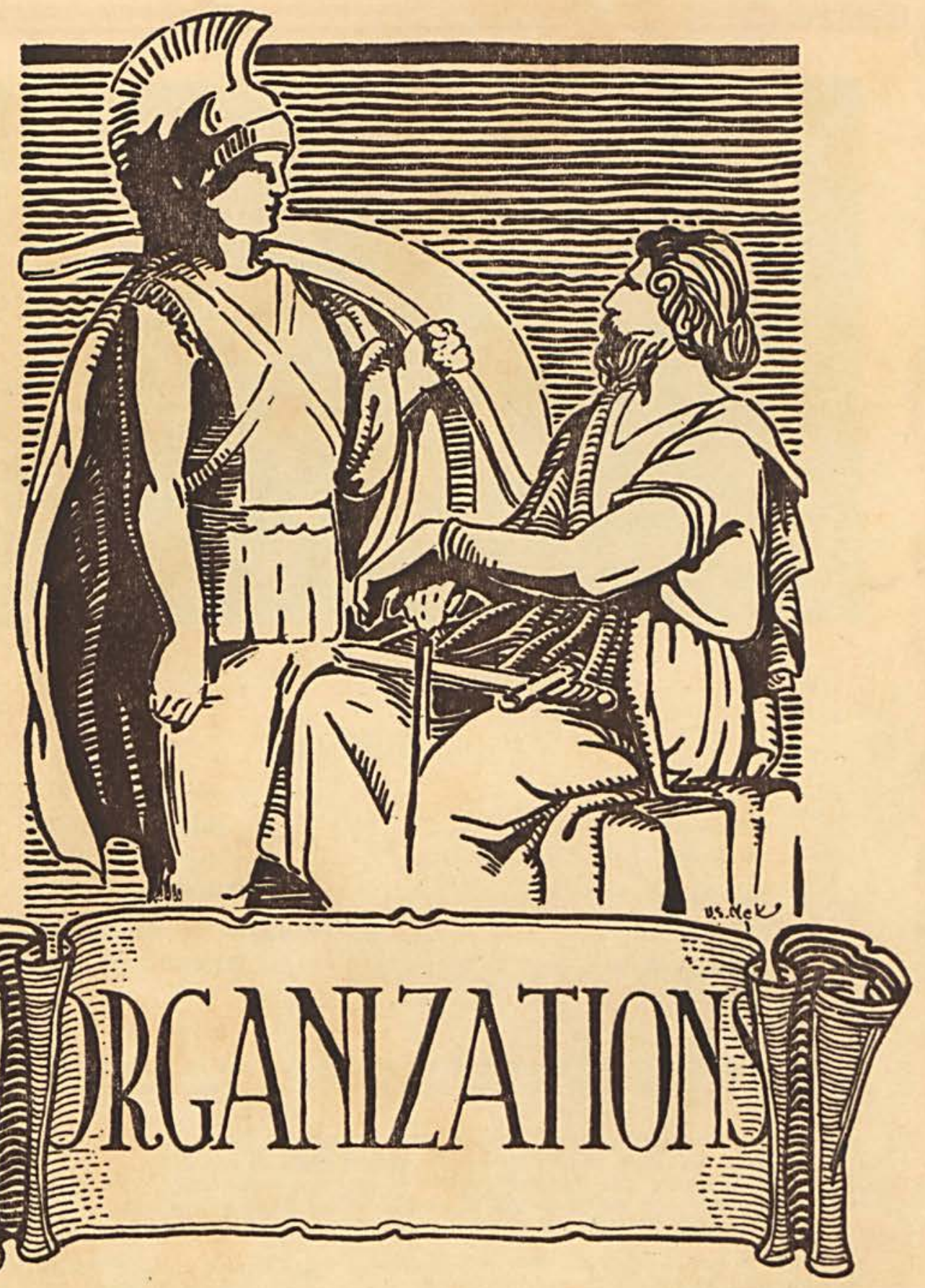




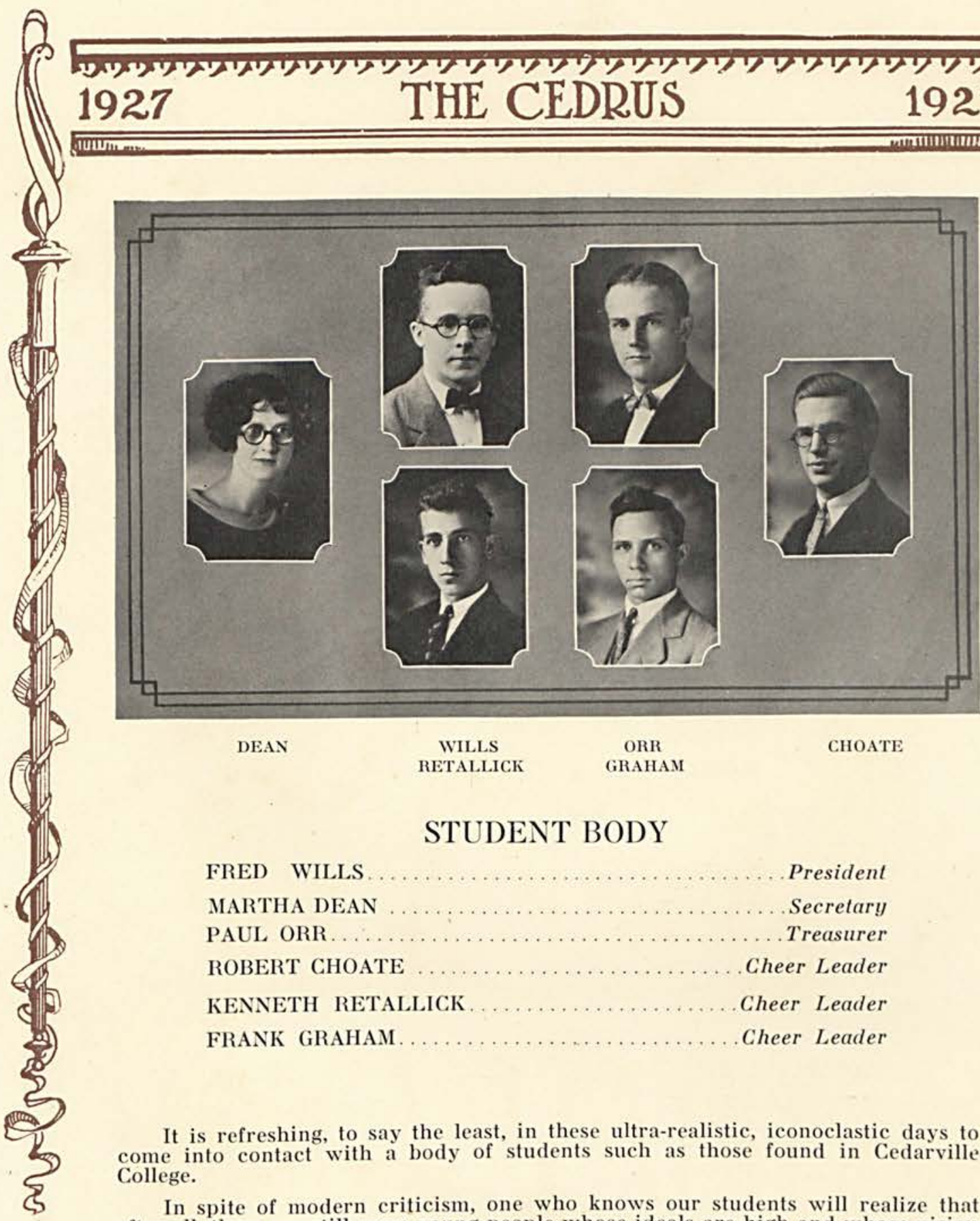

DEAN

WILLS

ORR

GRAHAM

CHOATE

\section{STUDENT BODY}

FRED WILLS ......................... President

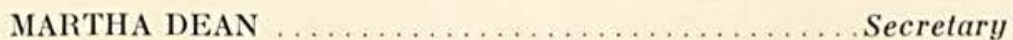

PAUL ORR ........................... Treasurer

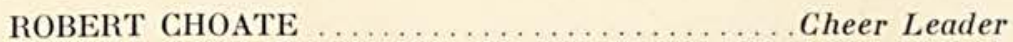

KENNETH RETALLICK.

Cheer Leader

FRANK GRAHAM.

Cheer Leader

It is refreshing, to say the least, in these ultra-realistic, iconoclastic days to come into contact with a body of students such as those found in Cedarville College.

In spite of modern criticism, one who knows our students will realize that after all, there are still some young people whose ideals are high and whose vision is unclouded. A natural process leaves at Cedarville only such men and women as are willing to sacrifice some of the pleasures of life in order that they may enjoy that full happiness that comes with the knowledge of a task well done.

Good times are not lacking. Athletics are well developed and studiès are given a fair share of student life. Under the leadership of a faithful, and capable faculty we develop whatever there is within us. Our cares are few, our joys are many.

Now we are enjoying our privileges, but at the same time we are fitting ourselves for the responsibilities of life.

-F. W. 

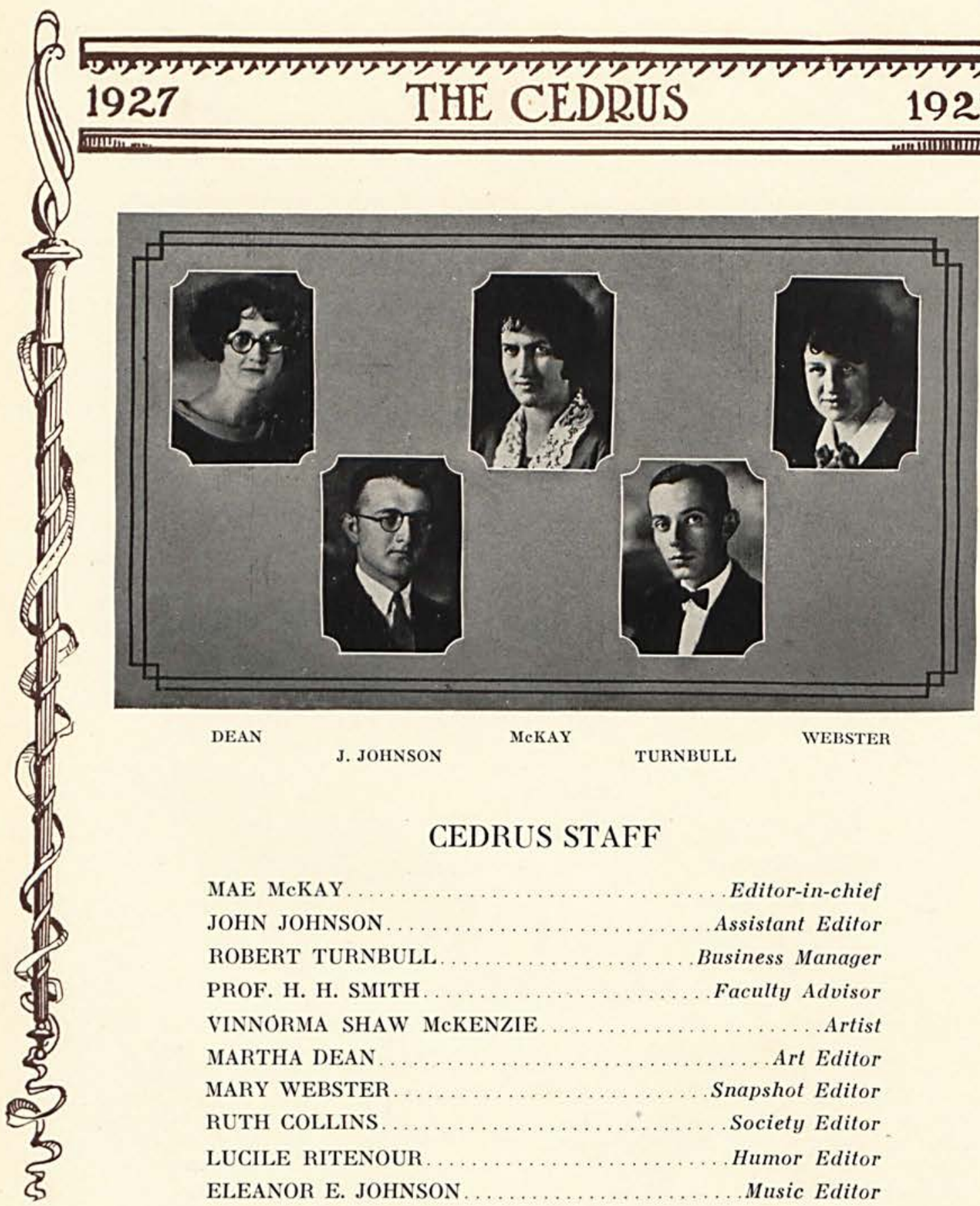

\section{CEDRUS STAFF}

MAE McKAY. Editor-in-chief JOHN JOHNSON. Assistant Editor ROBERT TURNBULL. ............................. Manager PROF. H. H. SMITH. . . . . . . . . . . . . . Faculty Advisor VINNORMA SHAW McKENZIE ................. MARTHA DEAN Art Editor

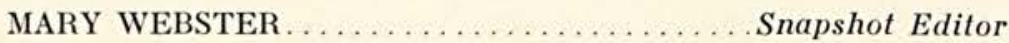
RUTH COLLINS Society Editor LUCILE RITENOUR Humor Editor ELEANOR E. JOHNSON Music Editor JAMES McMILLAN. Athletic Editor MARVIN WILLIAMS . Advertising Manager

The aim of the CEDRus Staff of 1927 has been to embody in the annual some of the hopes and visions of our college. We consider it a privilege, as well as a task, to be members of the CEDRus Staff. The publishing of an annual requires no small amount of labor. Difficulties have arisen from time to time that have almost overshadowed our hopes, but it has been our endeavor to compile as worthy a CenRus as possible. In reviewing our work, we realize that we have made many

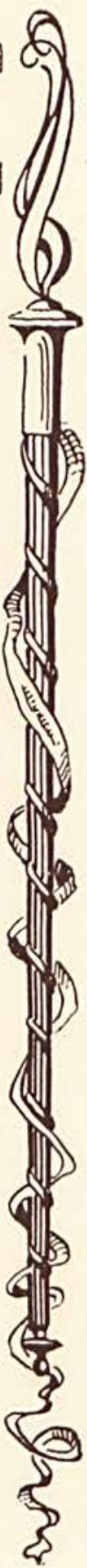



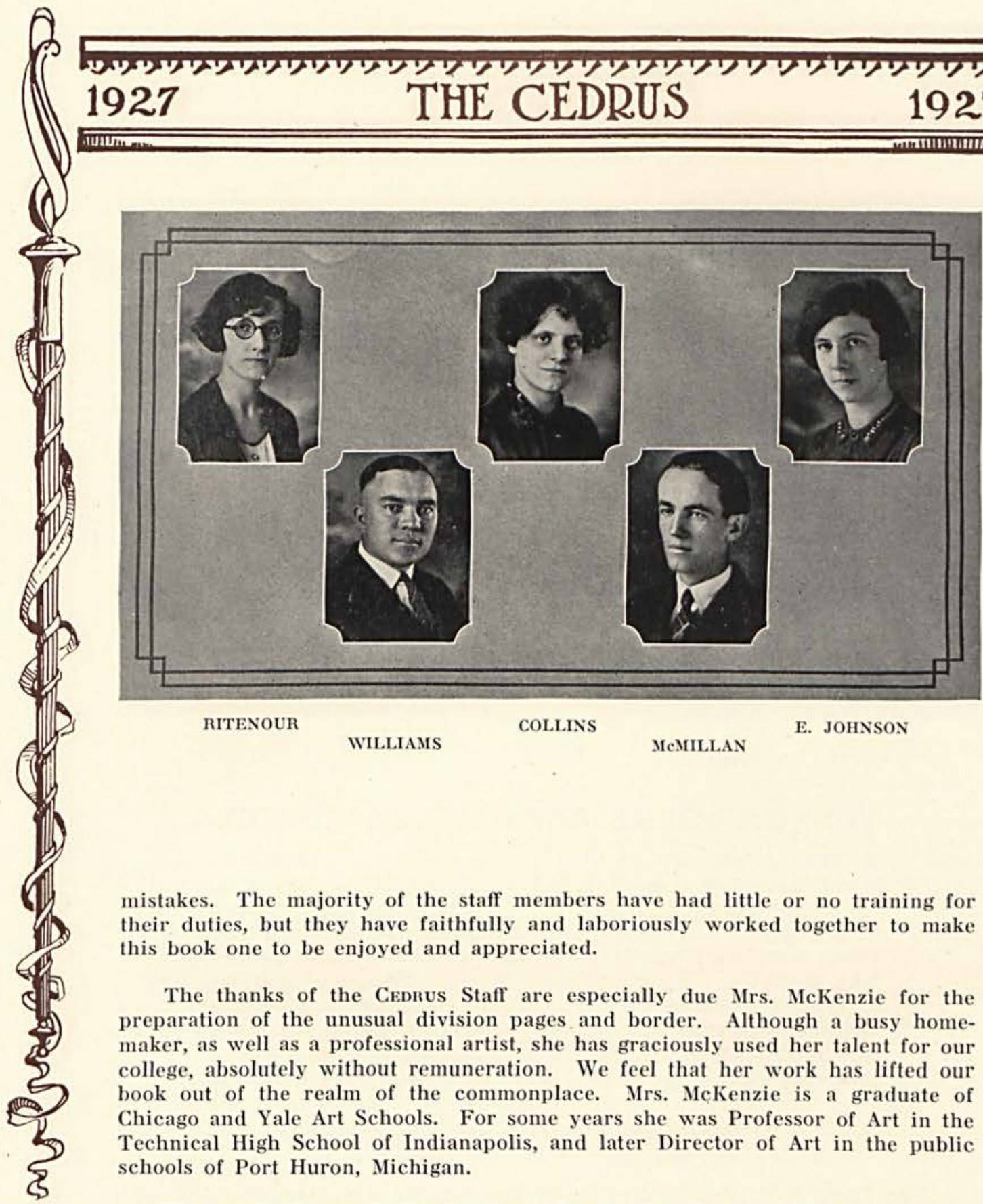

RITENOUR

WILLIAMS

COLLINS

MeMillan

E. JOHNSON

mistakes. The majority of the staff members have had little or no training for their duties, but they have faithfully and laboriously worked together to make this book one to be enjoyed and appreciated.

The thanks of the Cennus Staff are especially due Mrs. McKenzie for the preparation of the unusual division pages and border. Although a busy homemaker, as well as a professional artist, she has graciously used her talent for our college, absolutely without remuneration. We feel that her work has lifted our book out of the realm of the commonplace. Mrs. McKenzie is a graduate of Chicago and Yale Art Schools. For some years she was Professor of Art in the Technical High School of Indianapolis, and later Director of Art in the public schools of Port Huron, Michigan.

The work of compilation has been done under the capable supervision of Prof. H. H. Smith, who has served as Faculty Advisor for the past two years. We are very grateful to him for his efficient assistance. We thank also other members of the faculty and student body for the articles contributed to the book, and for interest shown throughout the year.

If through these pages you see a living, growing Cedarville College; if in after years they enable you to live again those college days of 1926-1927, we shall feel that our labors have not been in vain. -The Editor. 

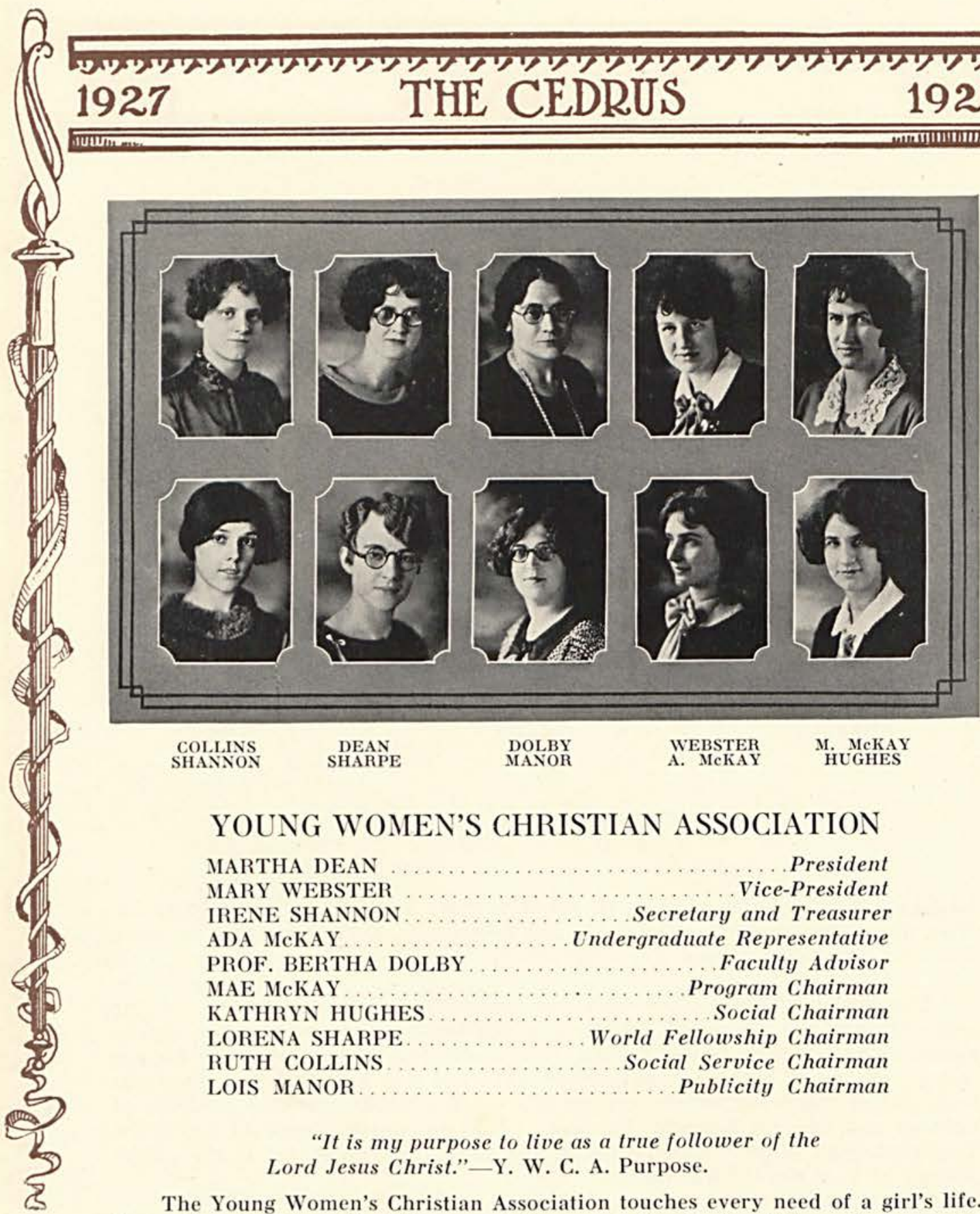

\section{YOUNG WOMEN'S CHRISTIAN ASSOCIATION}

MARTHA DEAN

MARY WEBSTER

IRENE SHANNON

ADA MeKAY

PROF, BERTHA DOLBY

MAE MCKAY

KATHRYN HUGHES

LORENA SHARPE

RUTH COLLINS

LOIS MANOR
President

Vice-President

Secretary and Treasurer

Undergraduate Representative

Faculty Advisor

Program Chairman

Social Chairman

World Fellowship Chairman

Social Service Chairman

Publicity Chairman

"It is my purpose to live as a true follower of the

Lord Jesus Christ."-Y. W. C. A. Purpose.

The Young Women's Christian Association touches every need of a girl's life. Pre-eminently it is a Christian association, according to the statement of purpose given above. By demanding belief in Christ as the one condition of membership, it endeavors to lead young women and girls to follow in the footsteps of Jesus.

In accordance with its symbol, the blue triangle, the Y. W. C. A. stands for a three-sided development-that of body and mind as well as spirit. A "Y" girl realizes the sacredness of her whole self - that body, mind, and soul are all creations of God. So she tries to keep them clean and pure, and develop them to their highest powers. By bringing them to their greatest usefulness in living Jesus' law of love, a "Y" girl has realized the purpose of the Y. W. C. A. 


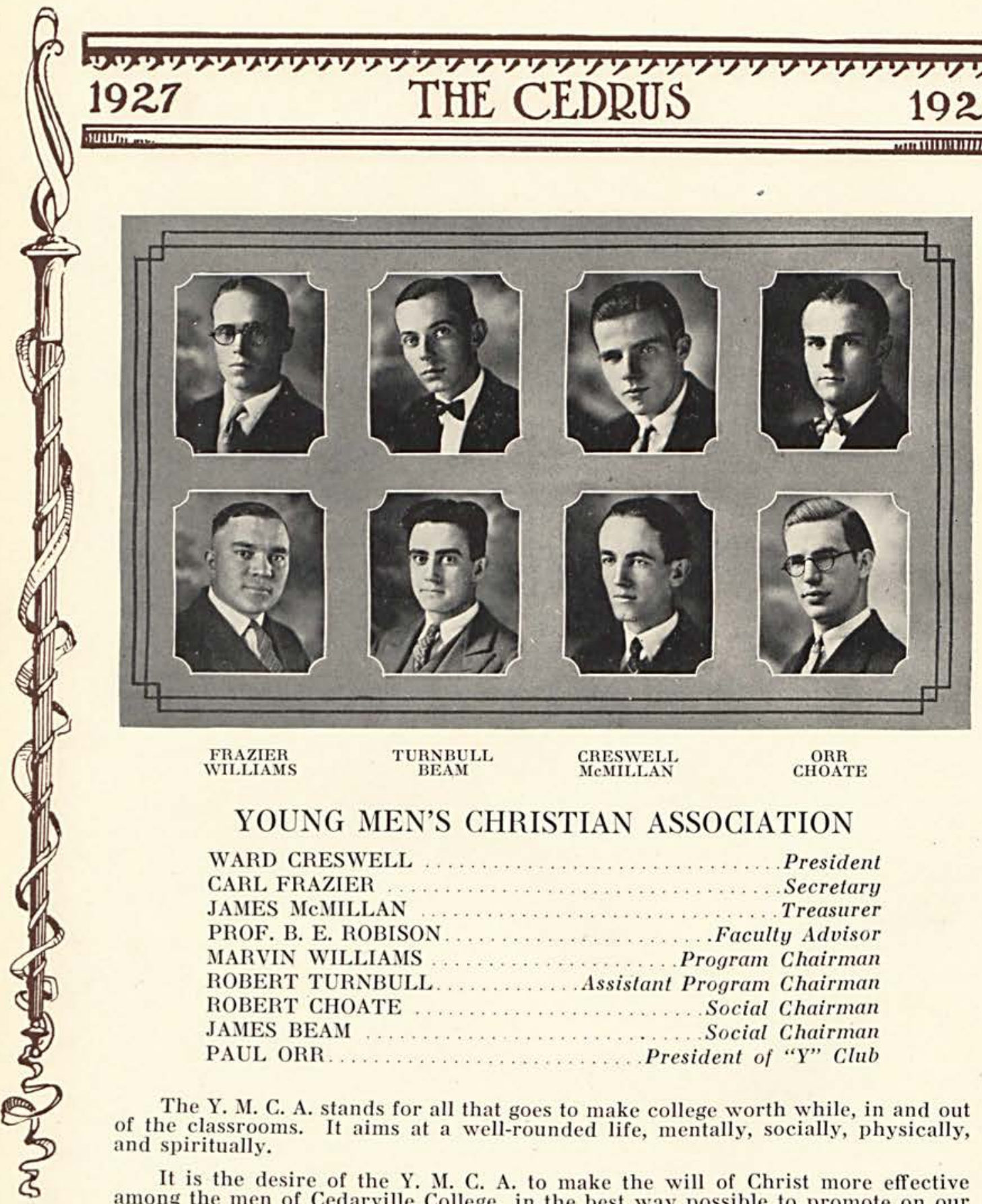

YOUNG MEN'S CHRISTIAN ASSOCIATION

WARD CRESWELL CARL FRAZIER

President

JAMES MCMILLAN

Secretary

PROF. B. E. ROBISON

Treasurer

MARVIN WILLIAMS

Faculty Advisor

ROBERT TURNBULL

ROBERT CHOATE

THE CEDRUS

8

JAMES BEAM

Program Chairman

PAUL ORR

Social Chairman

Social Chairman

President of "Y" Club

The Y. M. C. A. stands for all that goes to make college worth while, in and out of the classrooms. It aims at a well-rounded life, mentally, socially, physically, and spiritually.

It is the desire of the Y. M. C. A. to make the will of Christ more effective among the men of Cedarville College, in the best way possible to promote on our campus a positive moral and religious college spirit.

The association depends for its existence upon the rediscovering of men each year who will push forward in marking new trails and furnishing the power for a group of other individuals. It is largely true that each Fall the association has to be re-made almost entirely. The spirit of such a student-led organization seems to have died with the retirement of the old cabinet members. Yet, the incentive, through co-operation of a few remaining cabinet members of last year, has been one of encouragement and helpfulness as the days have gone by. The Y. M. C. A. officers feel that if we have given back anything it may be a step toward bigger things in our college life. 


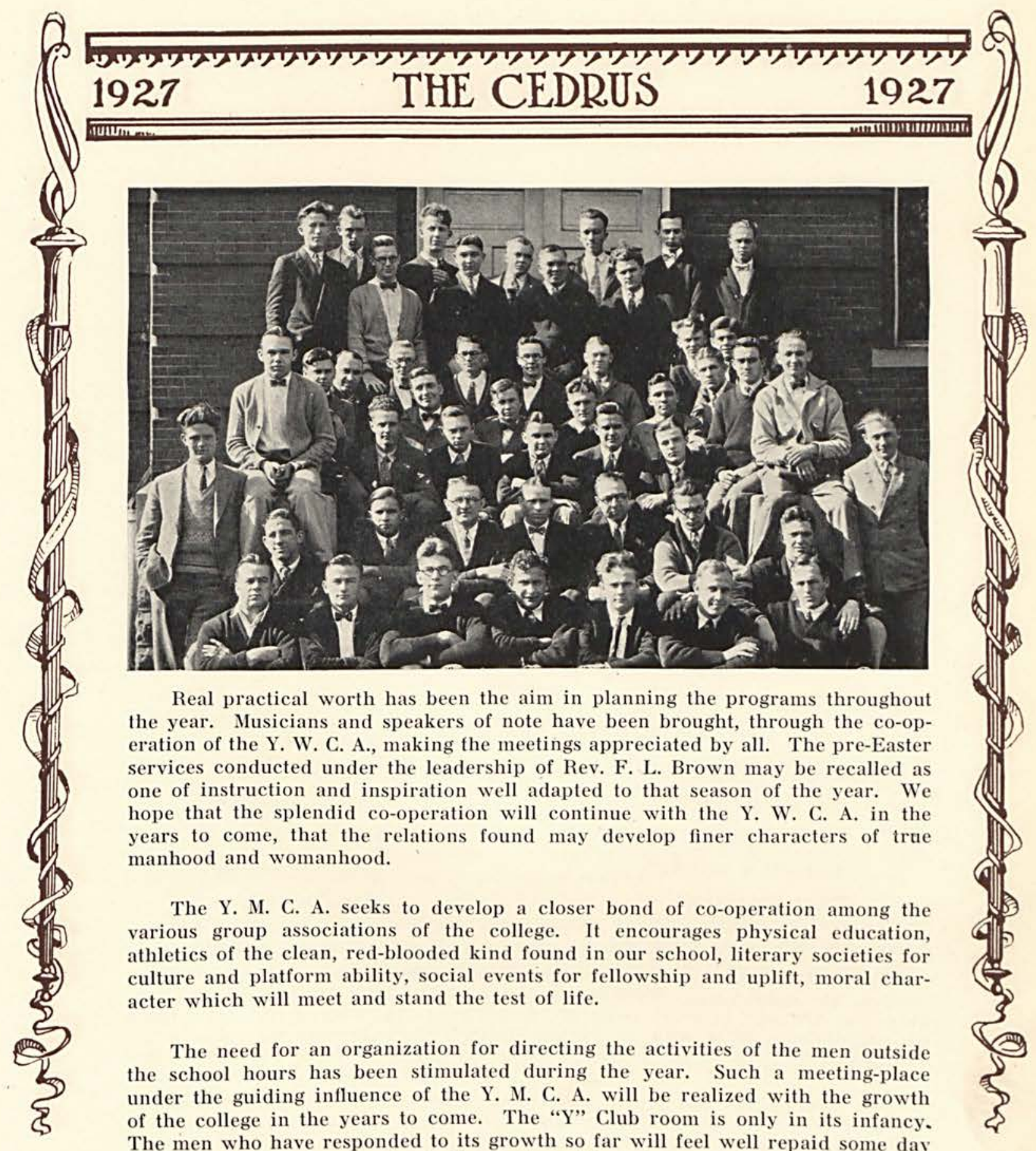
that they have had a part in starting such an ideal that must be realized.

The Y. M. C. A. seeks always to become in some way a part of the community life. The association takes this opportunity to thank the men of the village for their co-operation in making the Womanless Wedding a success. We, as a part of Cedarville College, are indebted to this community for its growth and development. We want, then, as large a part as possible in making a Bigger and Better Cedarville. -W. C. 


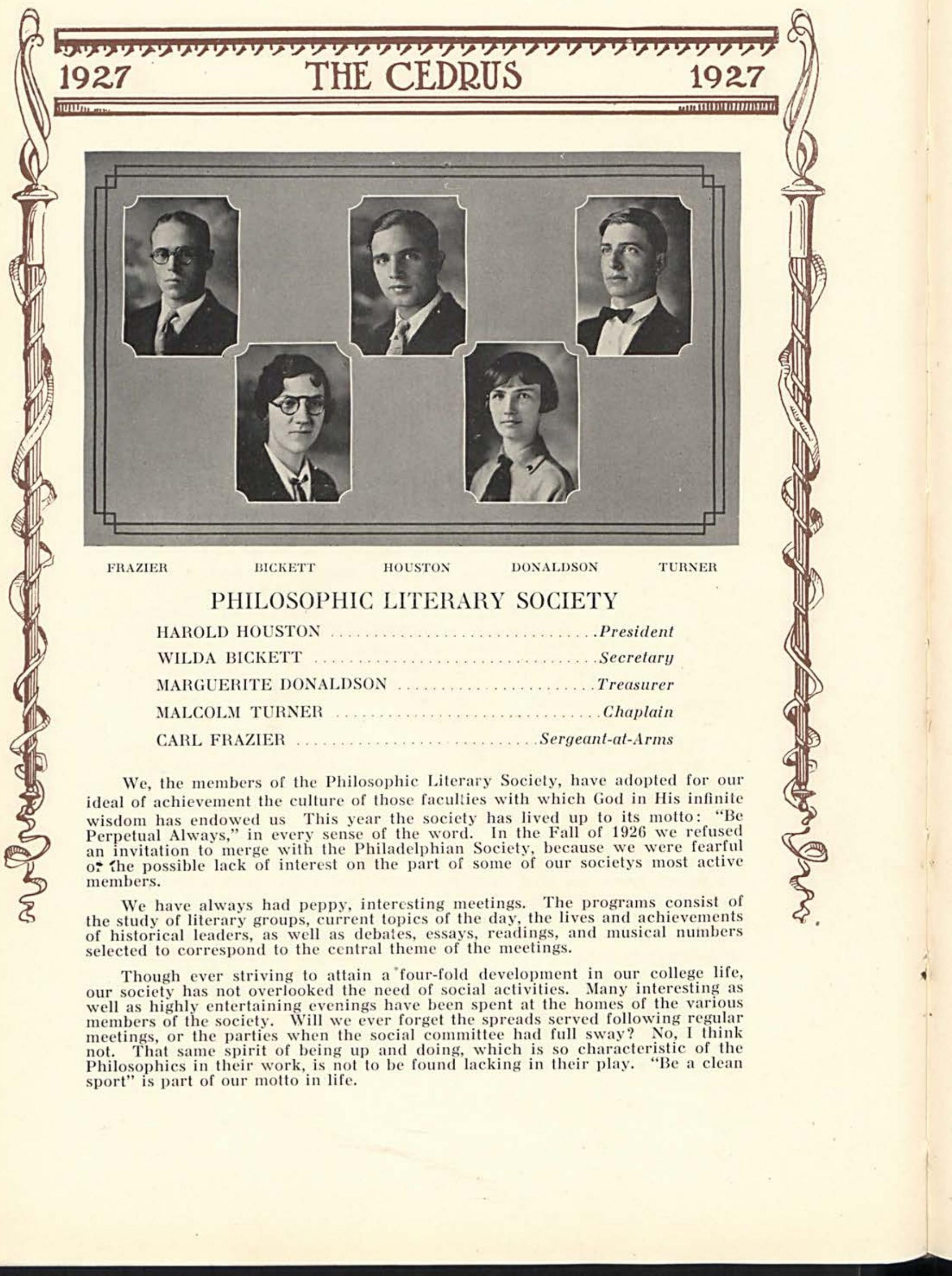




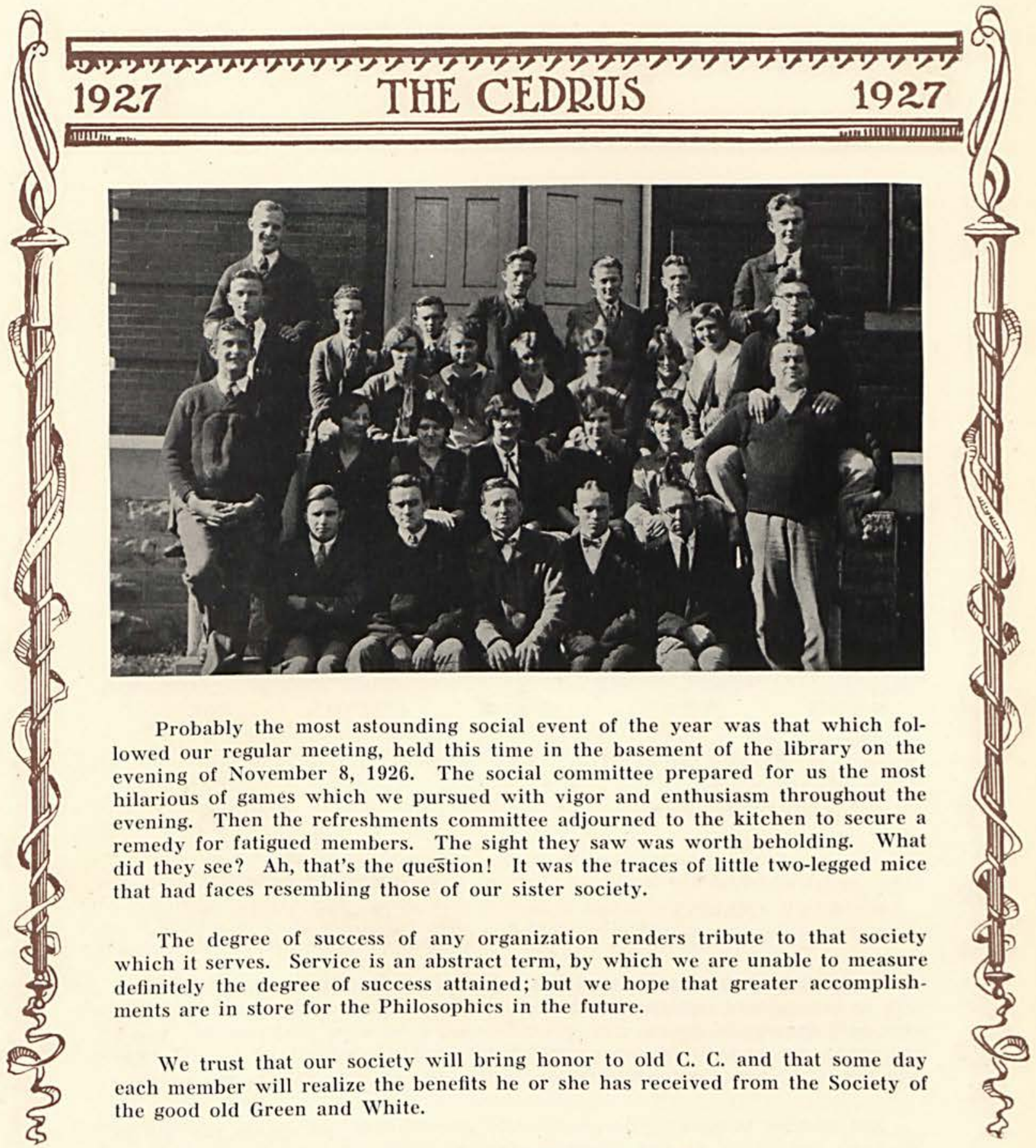

Officers for the Second Semester

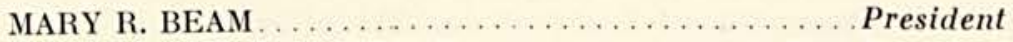

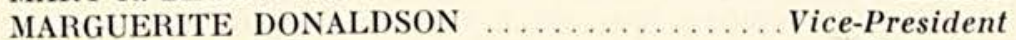

GRACE D. CLARK . . . . . . . . . . . . . . Secretary

CARL FRAZER . . . . . . . . . . . . .

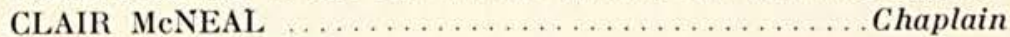

PAUL ARMSTRONG .........................

-G C. AND M. B. 


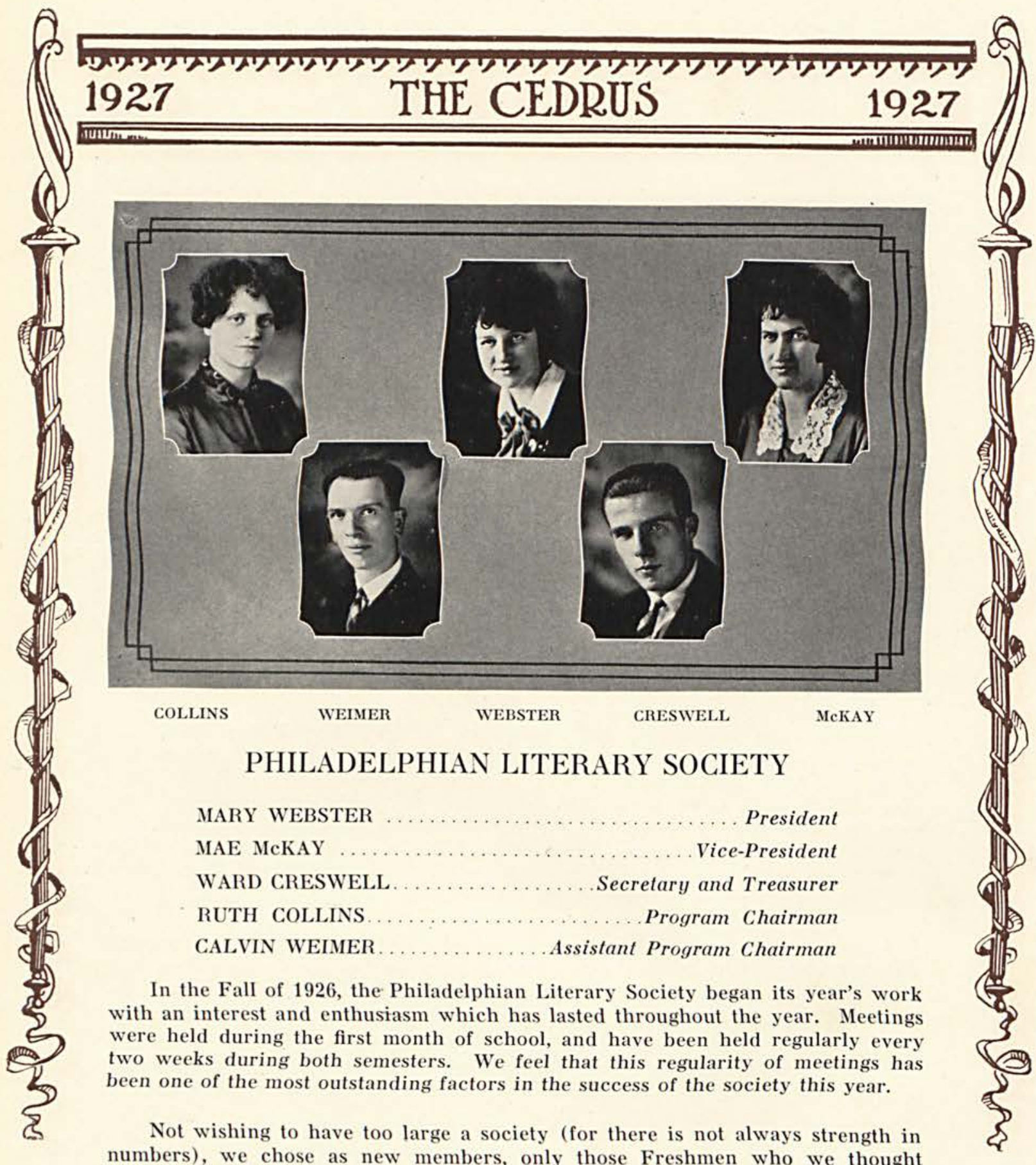

new members, only those Freshmen who we though would be of help in our society, by upholding the standards of a real Philadelphian; and after this year's work, we can say that we chose well. The co-operation which the new members have given has been splendid; and this has been another one of the many factors contributing to our success.

We, who have guided the destinies of the Philadelphians this year, felt that there were certain standards to which a society should attain, in order to be worthy of the name of a college literary. Throughout the whole year it has been our work to try to lead the society to the attainment of these standards. 


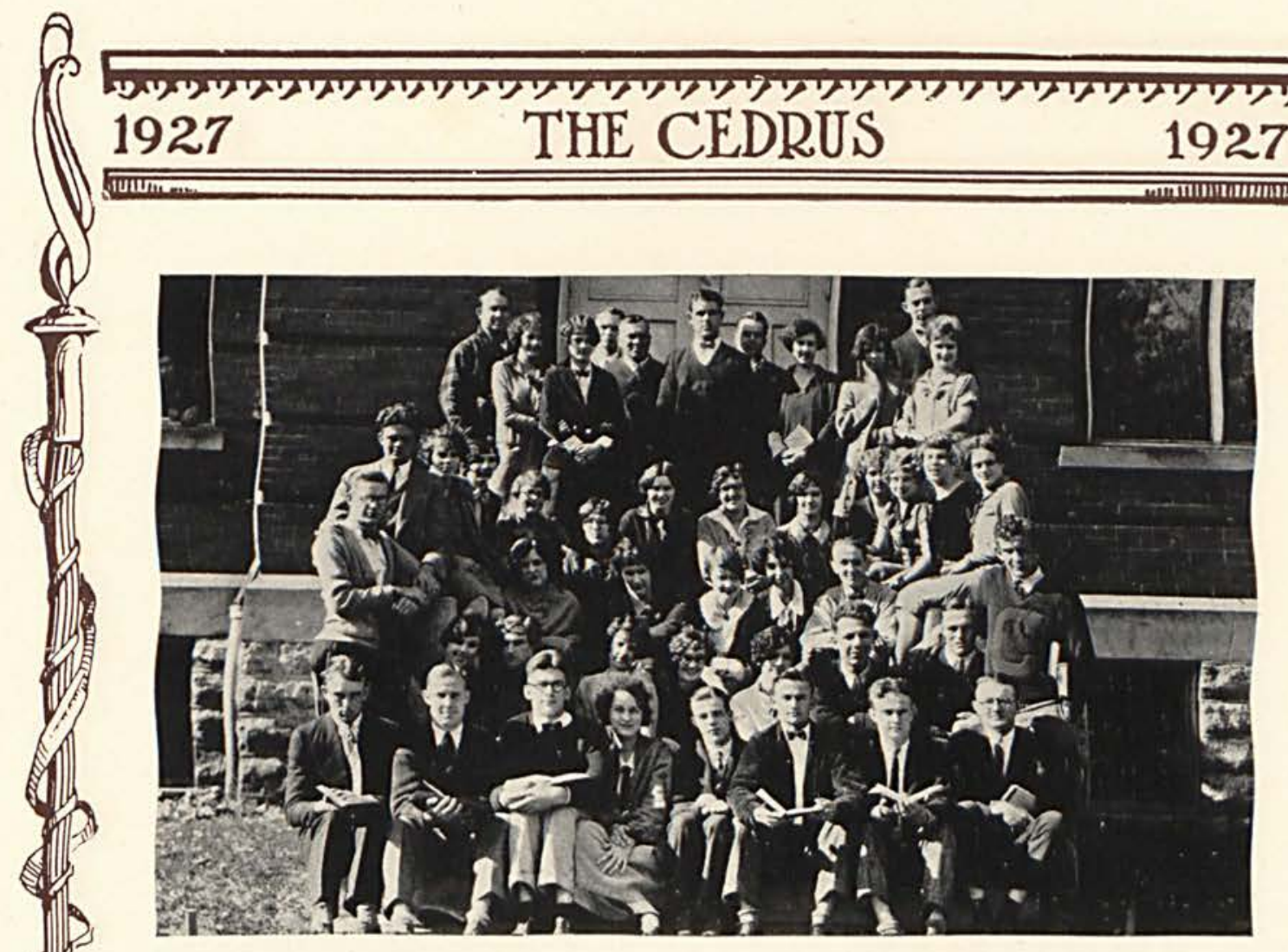

Often we hear it said that the college student of today is not interested in those things which develop the cultural side of his nature and that he is more interested in athletics and other activities. However, we merely cite the meetings of our society to prove the fact that the college student is interested in cultural activities.

Our aim throughout the year has been to cultivate the highest ideals, to raise the cultural standards of the college student, to gratify his aesthetic tastes, and to inspire in each member a love for the best in literature, which will continue to grow, long after college days are over, and he is no longer an active Philadelphian member.

Naturally our meetings have been varied, in order to carry out our aim. A series of meetings were held in which we discussed the topic, "Modern Poetry." At other meetings we have discussed such subjects as "Homes of Famous Americans," "World Events," "The Negro in Literature," and "The Christmas Spirit in Art, Literature, and Music." One of the most interesting and enjoyable meetings of the year was one held in commemoration of the Beethoven Centenary. Interesting events concerning the lives of the masters of music were given, as well as selections from their masterpieces.

We know that the success of our society cannot be measured in one year because, many times, our failures seem to overshadow our successes. Nevertheless, we do believe that we are steadily improving from year to year.

However, during this year, if we, through our efforts, have raised the cultural standards of the members of our society in any small degree, if we have inspired in them a love for the best in literature, art, and music, and if in after years when thinking of their college days they will remember the Philadelphian Society with interest and appreciation of the lessons learned and the good times enjoyed, we shall feel that we have "not worked in vain." -M. W. 


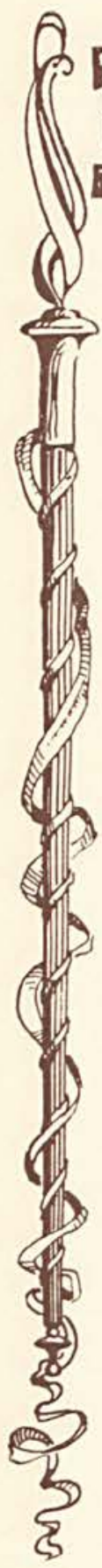

\section{CEDAR NEEDLES STAFF}

LAWRENCE MCLEAN ......................... Editor

DAVID ADAIR ...................................... Manager

PROF. BERTHA DOLBY . ..................Faculty Advisor

DALLAS MARSHALL ............................... Eports Editor

HELEN ILIFFE . . . . . . . . . . . . . . . . . . Society Editor

BERTRAMI FLEMING.....................Alumni Editor

ROBERT JACOBS ......................... Feature Editor

LAWRENCE DOUTHETT ...............Advertising Manager

\section{CEDAR NEEDLES}

At the start of the second semester a group of students made it known that a class in Journalism, if started, would be attended by them. Miss Dolby, the teacher in Rhetoric, was chosen as the teacher for this new class. The class in Journalism was not altogether a new experiment for the school, as, the year previous, a class was in existence.

The first thing of importance to be considered was the possibility of a paper for the entire student body published by Cedarville College students. As the past efforts at such a thing had always proven failures, the project thus presented by this class was met with a bit of skepticism by not a few people concerned.

The enthusiasm of the little group representing the class was so great that nothing but an attempt could quelch them. Finally the sanction of the faculty was procured and plans were completed for the issuing of a paper named Cedar Needles. On the night of March 30, while the students and faculty were assembled in the Alfred Memorial Auditorium, being entertained by the Girls' Glee Club of Wittenberg, a bombshell was burst in their midst. To the surprise of everyone, a paper, for the students and by the students, was passed out to the crowd. The gritty bunch of students had made a school paper a success and had proved to the people that it could be handled by the students themselves.

Due to the late start it was possible to issue only three editions. Next year a very great success is sure to be in store for the class; and our hats are off to the students who had the nerve and ability to carry on, in the face of great odds, and to the teacher who so faithfully stood behind them in their every effort.

-L. M. 


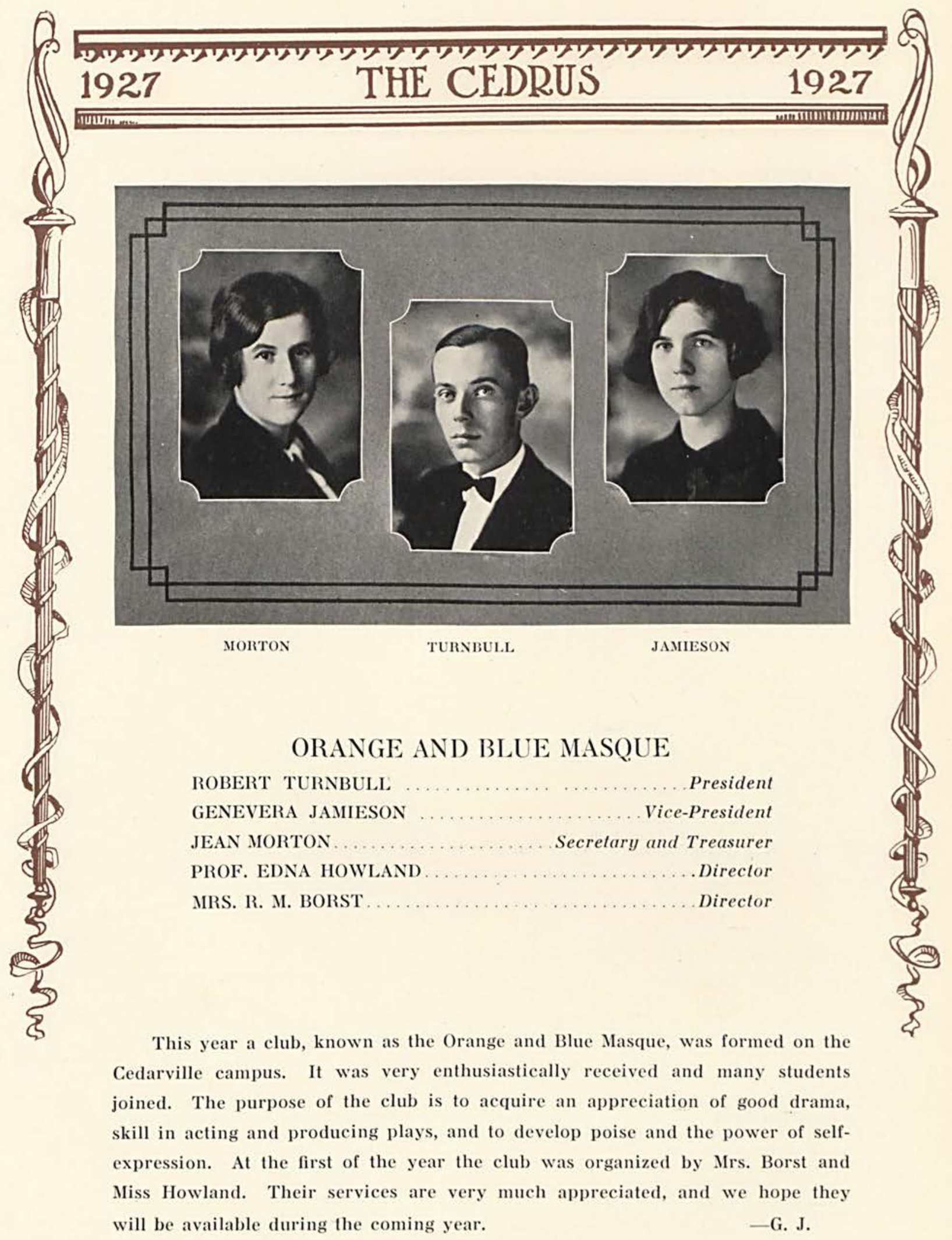




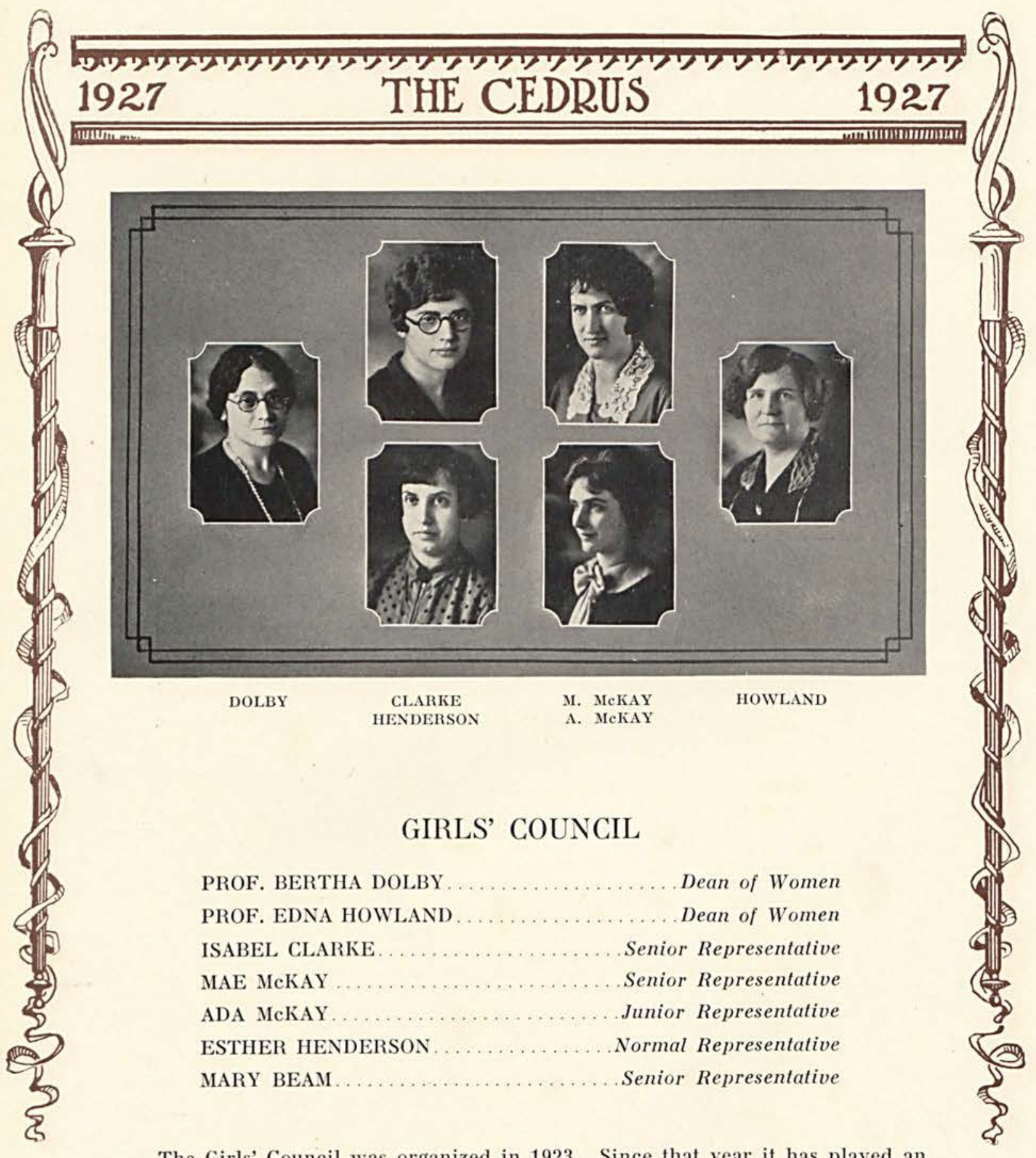

The Girls' Council was organized in 1923. Since that year it has played an active part in advising and supervising the girls. Supervision is more difficult because the girls must be located in so many different homes. This year a special effort has been made to secure co-operation between the Deans of Women and the House Mothers, which is necessary for the well-being and happiness of the girls. The council has been very helpful as a medium through which problems were made known and solved. The few regulations governing conduct formulated by the Deans and council are adopted by the girls in a general meeting each school year. The council has become quite indispensable to the work of housing and caring for the girls who make Cedarville their home during the school year. -B. E. D. 


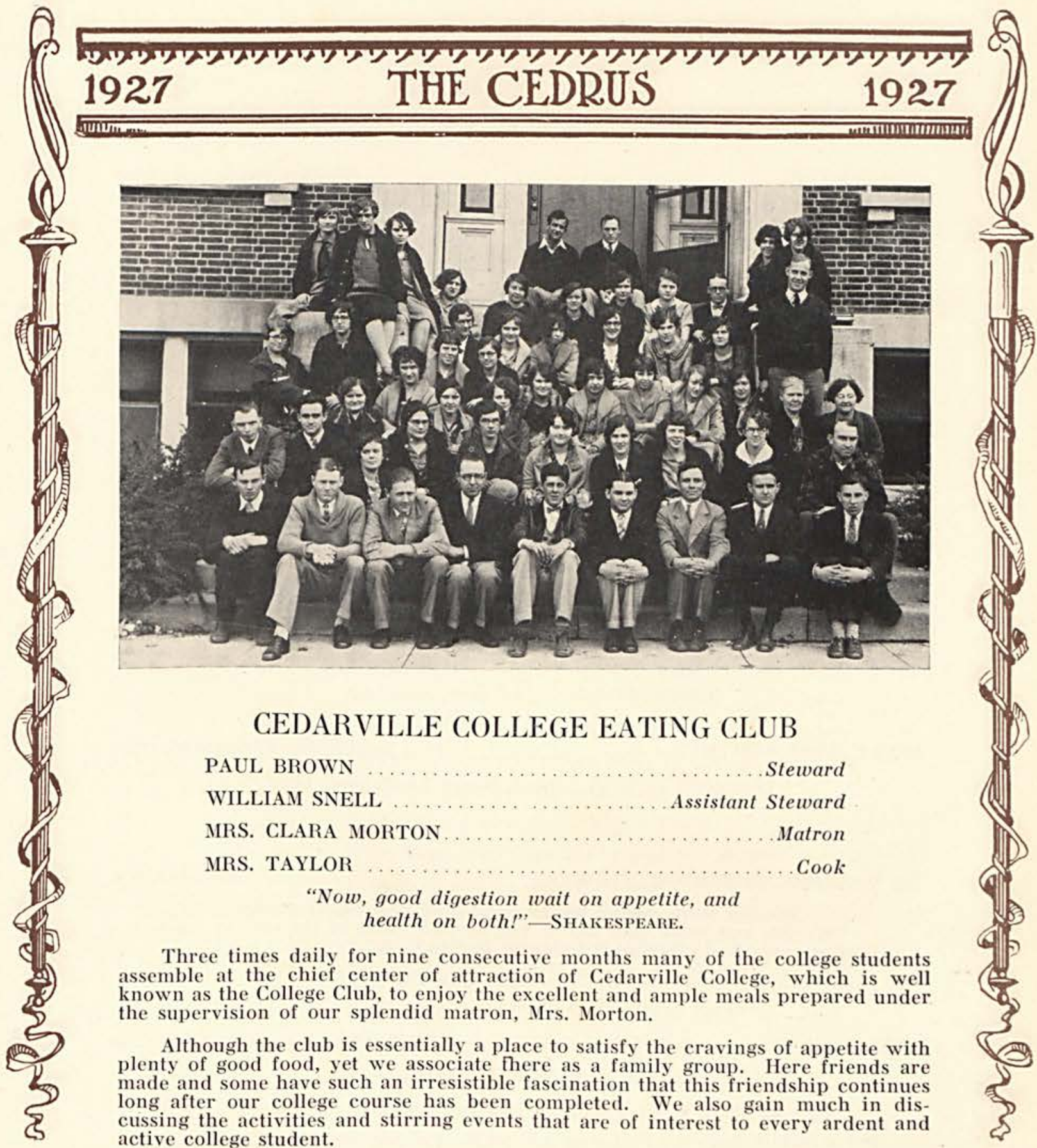

The members of the body elect a steward annually to serve as the leader of the group. This year we have been fortunate in securing Paul Brown, a farsighted and precocious young man, assisted by a careful wizard of finance, which has been a big factor in keeping the student body at the highest peak of our attention wave. These men alone of all the members enrolled, can enumerate the difficulties and worries attached to the careful management of a hunger-satisfying club, but they have met the situation very efficiently in making themselves equal to the occasion. Undoubtedly after careful analyzing the situation the year will close very successfully for the club from many standpoints. 


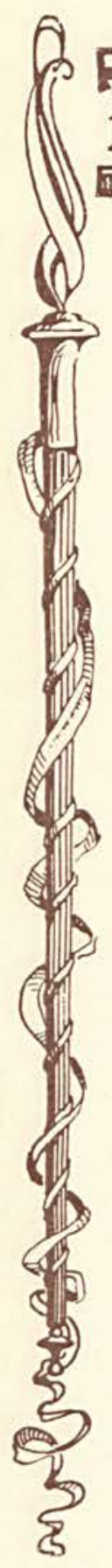

\section{THE ALUMNI ASSOCIATION}

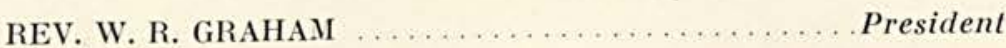

J. A, FINNEY

First Vice-President

LULA HENDERSON

Second Vice-President

MABLE STORMONT

Secretary and Treasurer

ALBERTA CRESWELL

Corresponding Secretary

The 1927 Cennus Staff feels that the Cenrus would not be complete without an Alumni Section. We have made a special effort to ge: in touch with each member of the Alumni Association. We hope that this section may be retained as a permanent feature of the annual, and that the Alumni may look forward to the publication of the Cenpus with as much interest as does the active student body.

We are very grateful to those of the Alumni who, in reply to our request, have found time to furnish us the following information:

MISS CARRIE NORTHUP

1954 Kenton St., Springfield, Ohio

Instructor in High School, North Lewisburg, Ohio.

MR. AND MIRS. ROBERT W. STEWART

Houston, Ky.

Mission work among the mountains of Eastern Kentucky.

"We like our work very much, but we still think of the society meetings, spreads, and other good times we had in C. C."

JOHN F. NASH

531 Ludlow Arcade, Dayton, Ohio

Public Accountant.

"Talking about fights, I wonder just how many of the Alumni remember a certain flag rush that was held on the college campus, when 'Windy Bull, equipped with spurs, tried to climb a greased pole, at the top of which had been placed the colors of the opposing faction, when girls jabbed hat pins (the good old days of big hats and long hat pins!) into numerous backs, when shirts were torn and hair was pulled, and everybody had blood in their eyes?

"With greetings to all my old friends of college days." 


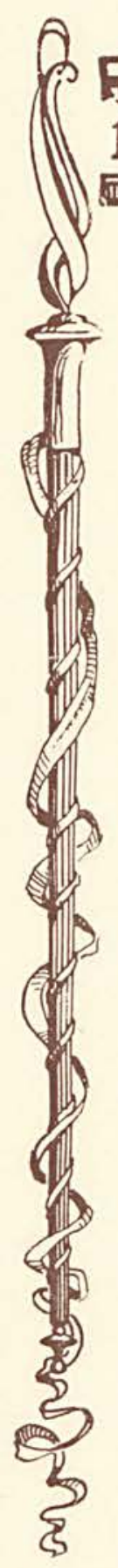

MRS. MARGARET KEAN Magnolia, Ohio

"Hail to the Class of ' 19 !

"Between the double duties of housewife and schoolteaching I find myself quite busy, but not so m.xh so but that my mind often reverts to 'ye olden days in college halls.'

"How well do I recall the day when we all cut Lab and left Miss Ray looking in astonishment, not knowing whi:her her flock went.

\begin{abstract}
"And we poor sinners, like all the rest,
Bent on fun with all its zest,

For a roisterous time with all the joys

That make up life for girls and boys

Of college life-those days gone by
\end{abstract}

will ne'er return to you and I. (Poetic license!)

And those poor Freshies, I see them yet,

How they did stew and fret

When we shut them in at the outer gate

And there they had to stand and wait

Our sweet time to step aside and

Let their flivvers sweetly glide

Thru the passage-way and go-

They knew where, but I didn't know.

Well, those dear days have come and gone

As college chums go one by one

Out in life's tempestuous sea

To dream of days that used to be.

May blessings crown you one and all;

Down Earth's highways may there befall

To each of you when you grow old,

A crown of gold with stars untold.

And heralds open wide the Gate

And never one of you be late, 


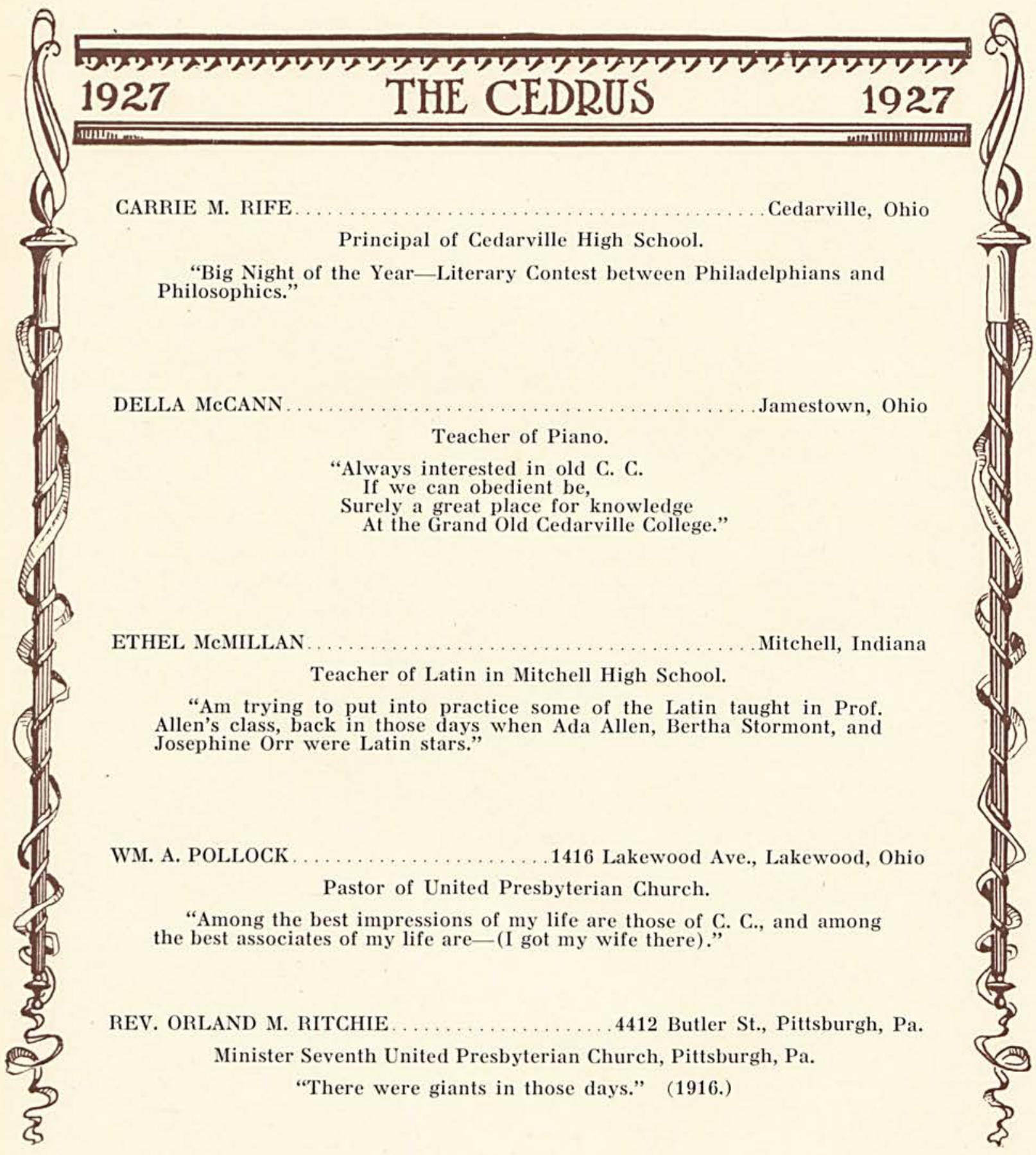

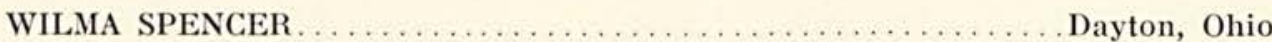

Teacher of English in Steele High School.

S. CALVIN WRIGHT, ’03 663 South Detroit St., Xenia, Ohio Probate and Juvenile Judge, Greene County, Ohio. 


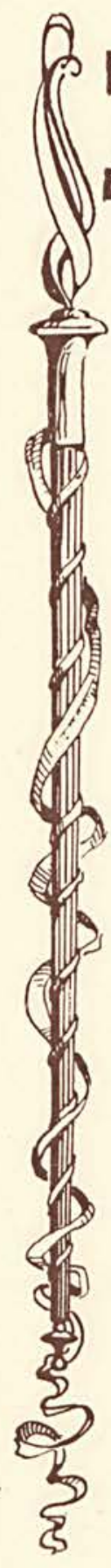

W. A. CONDON, 1900 .

Uhrichsville, Ohio

Pastor of the Presbyterian Church.

"Reminder-Who stole Mike McCarty's guinea?"

JOHN ORR STEWART.

Richmond, Ky.

Director of Music.

"The class of which I was a member were all blood relatives except one and she related to the others by marriage. Of a class of six, two of the members have since married; one member is a preacher, two are teachers, three are housewives. The thing that has remained as a part of the memories of our Senior year is the fine parties we had and the extra fine meals we enjoyed together."

\section{3}

EARLE COLLINS

Assuit College.

Assuit, Egypt

ARTHUR EWBANK Principal of High School.

Chester, Ohio

MARY FLANAGAN

Cedarville, Ohio

JAMES KYLE. . . . . . . . . . . . . . . . . . . New Carlisle, Ohio Teacher in Olive Branch High School.

ALICE LACKEY

Cedarville, Ohio

MARJORIE McCLELLAN.

Teacher in High School.

Troy, Ohio

EDWIN McKUNE

Pastor U. P. Church.

Rushville, Ind.

RUTH SHAW

Yellow Springs, Ohio

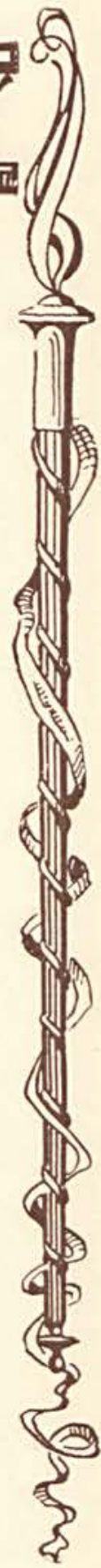

ROBERT STEWART

Pastor R. P. Church.

Houston, Ky.

ERNEST WRIGHT

Teacher in High School.

Harrisonburg, Va.

MYRTLE BICKETT

Teacher in High School.

Fair Haven, Ohio 
HARPER BICKETT

Xenia, Ohio

MRS. LEE THOMAS

Yellow Springs, Ohio

THELMA DEACON

Teacher in Selma High School.

LUCILLE JOHNSON

Teacher in High School.

Greenfield, Ohio

MRS. GAVIN REILLY

Camden, Ohio

NETTIE SHAW

Teacher in High School.

MARION STORMONT

Teacher in High School.

DONALD WICKERHAM

Teacher in High School.

Largo, Fla.

MRS. PAUL WILLIAMS

Teacher in High School.

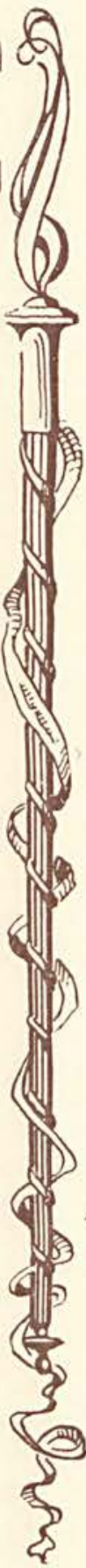

HOWARD ARTHUR

\section{5}

AVENELLE BRIGNER

Teacher in High School.

PAULINE COLLINS

Teacher in High School.

Kenmore, Ohio

Glenford, Ohio

Cedarville, Ohio

LOIS CUMMINGS

Dayton, Ohio

ELIZABETH GIFFORD

Teacher in High School.

LACLEDE MARKLE

Chaplain in the Navy.

Cedarville, Ohio

Plattsburg, Ohio Kenmore, Ohio

RUTH MCPHERSON Teacher in Urbana Township High School.

DOROTHY OGLESBEE

$$
\text { Director of Music. }
$$

Van Lear, Ky.

WALKER TAYLOR

Teacher in High School.

Newport, R. I.

Dayton, Ohio Arcanum, Ohio

CARL SMITH Teacher in Beaver High School.

Port William, Ohio MRS. ELTON HAWES Spring Valley, Ohio

Osborne, Ohio 


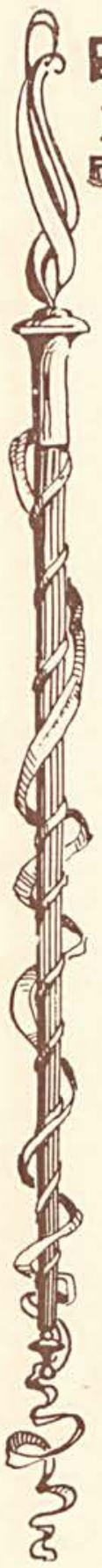

\section{THE CEDRUS}

LUCILLE ANDERSON

Teacher in High School.

Ostrander, Ohio

ELIZABETH BARNETT Teacher in High School.

Sommerville, Ohio

FREDA CROWELL Teacher.

Burnettsville, Ind.

LAWRENCE CURRIE Engineer of Construction.

Elyria, Ohio

RUTH DOBBINS Cedarville, Ohio

DONALD FUNK. Machinist.

Springfield, Ohio

FRANKLIN GERREN

Hookstown, Pa.

LENA HASTINGS Teacher in Junior High School.

Springfield, Ohio

MARSTON HUNT Teacher in High School.

Oncanta, Ala.

ELMER JURKAT Postgraduate Student.

H. C. MARMON Superintendent of High School.

Mowrystown, Ohio HAROLD MYERS Chillicothe, Ohio ELIZABETH OUTRAM Teacher in Community High School. Booneville, Ky. JUNE THOMPSON Teacher in High School. Springboro, Ohio

"June would like to be back in C. C.

Could Cedarville stand 'June' the year round."

CHARLES TOWNSLEY Cedarville, Ohio WINIFRED STUCKEY Selma, Ohio Teacher. 


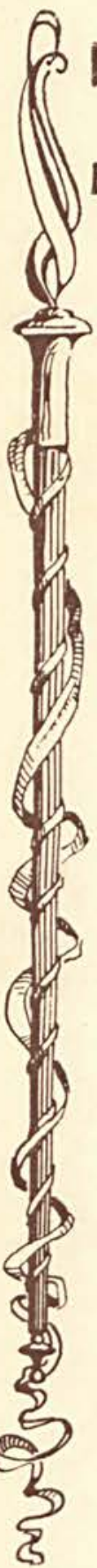

\section{All Hail to Alma Mater}

Cedarville's a college in a grand old state, Builded by the hands of our Maker Great, Guiding eager students thru the open gate Of dear old Cedarville.

Fitting them for champions of the truth and right, Arming them completely for the coming fight, Leading them to victory over wrong and might, At dear old Cedarville.

Senior, Freshman, Soph and Junior too,

Join your hearts and efforts and in everything you do.

"Onward, Upward," be your motto still.

Follow close the leading

Of your dear old Cedarville.

I want to go back to old C. C.,

The best school in the land,

And go to all the games again

And shout Rah! Rah!

To Alma Mater we will pledge

Our love and loyalty.

I want to go back, I gotta go back

To old C. C. 


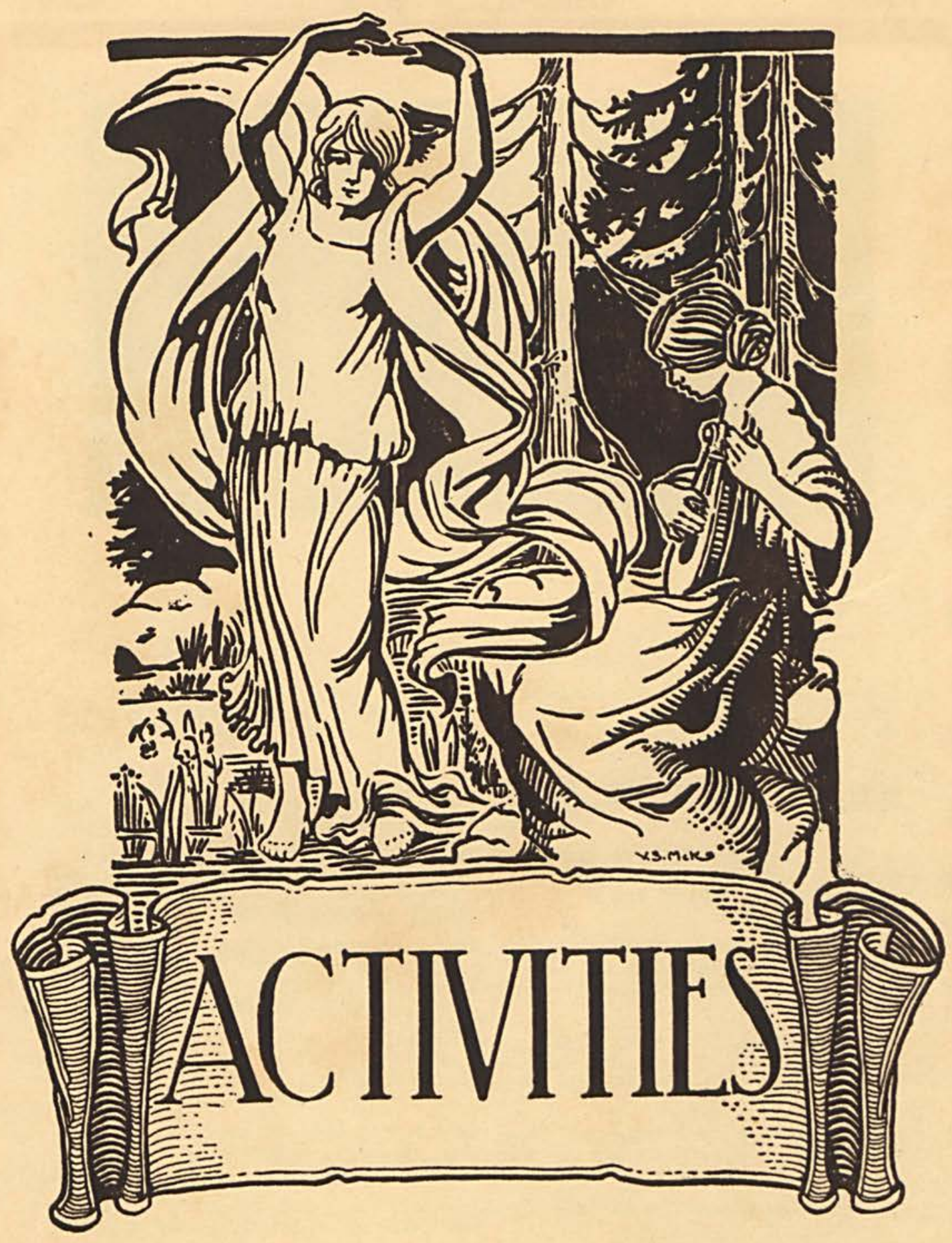





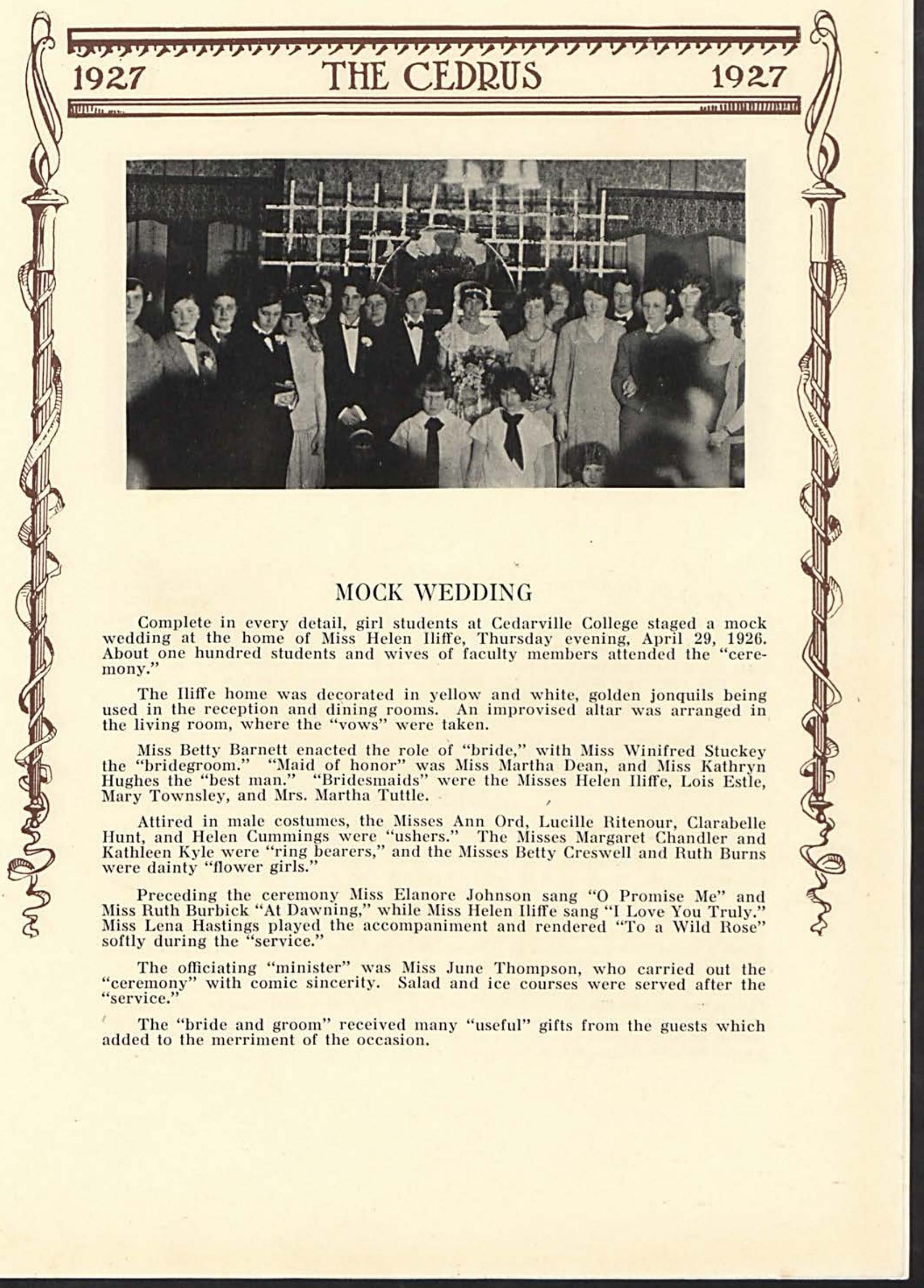




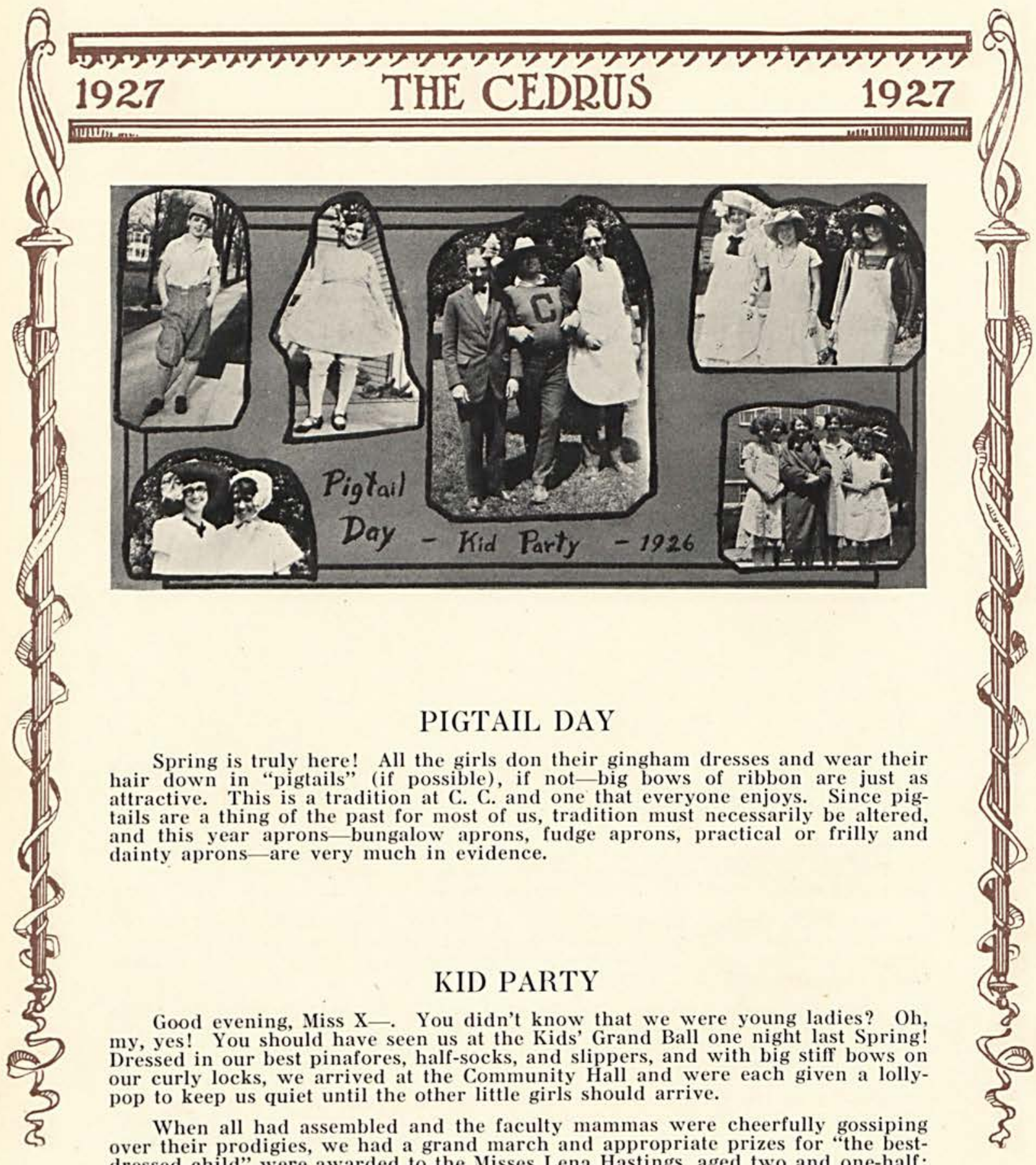
dressed child" were awarded to the Misses Lena Hastings, aged two and one-half; June Thompson, aged five; and Mary Beam, aged eight.

The evening's frolic consisted of the games common to childhood, such as "Drop the Handkerchief" and "Cat and Rat." Dainty refreshments consisting of ice-cream cones and lolly-pops were served. After a rollicking song fest we departed before bedtime (?), each with a toy whistle with which to keep the campus awake for the remainder of the week. -M. D. 


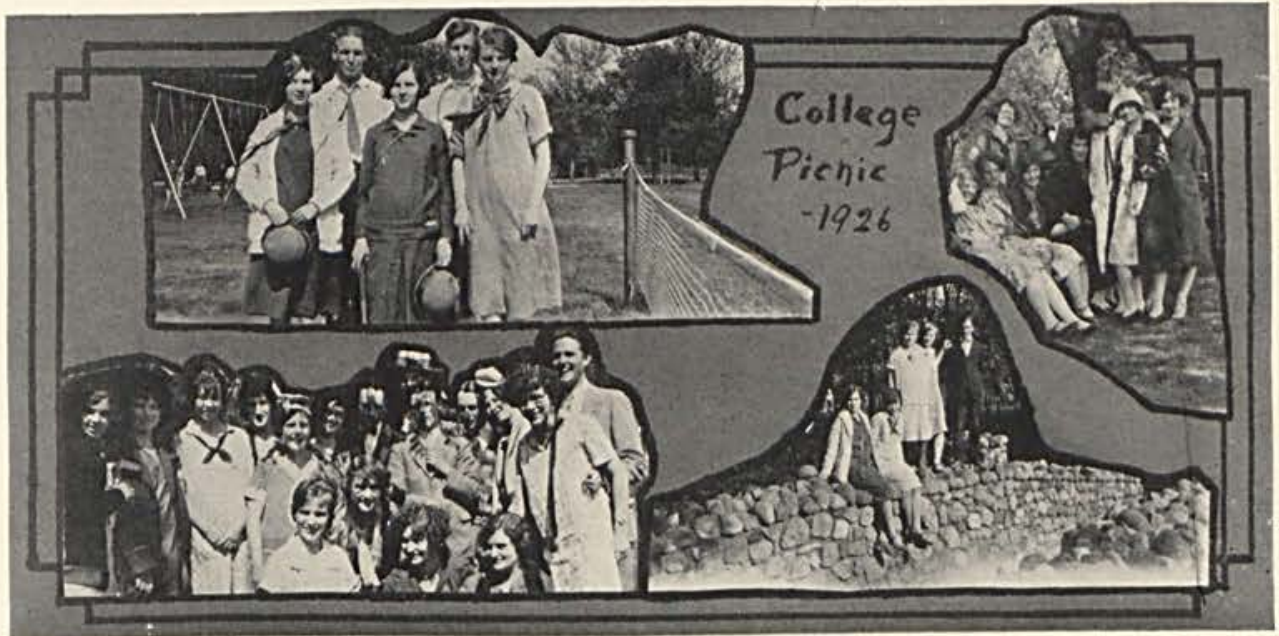

\section{C. PICNIC}

The usual argument was held last Spring as to the place for the Senior Picnic. Suggestions ranged from the Clifton Cliffs to the Bermuda Islands. After due consideration Snider's Park, Springfield, was chosen and thence we journeyed that twentieth of May. It is needless to say we did have "eats" and lots of them, and the afternoon was spent in tennis, golf, and swimming as well as various amusements afforded in the park. Evening brought the close of another pleasant day for C. C. students.

\section{JUNIOR-SENIOR BANQUET OF 1926}

On May the sixth, the Junior-Senior Banquet was held in the main dining hall of the Engineers' Club of Dayton. Fifty guests were seated at the large U-shaped table, which was cleverly decorated in the Senior colors, green and white. Three large baskets of American Beauty roses adorned the table. The favors were green and white crystal candy sticks made in the form of a tripod, holding small white place cards on the top. Tiny green baskets of mints on the white medallion were placed under the tripod. A very delicious four-course dinner was served by the club consisting of: Fruit cocktail; creamed chicken on patties, French fried potatoes, green lima beans, Parker House rolls, and butter; head lettuce with Thousand Island dressing; Neapolitan ice-cream, cake and coffee.

Miss Marie Koehnen of Dayton gave a program of selections on the harp during the dinner hour.

The program of the evening was suggestive of Browning's "Pippa Passes,"morning, noon, and night. The toast, "Morning," representing the Youth, was given by Miss Martha Dean, followed with a solo, "At Dawning," by Miss Stuckey. The "Noon," representing the Activity, was given by Prof. H. H. Smith, followed with a solo, "My Task," by Miss Burbick. "Evening," representing Retrospection, was given by Miss Dobbins, followed with a solo, "The End of a Perfect Day," by Miss Elizabeth Creswell. Dr. W. R. McChesney gave the concluding toast-the "Charge to the Classes." Mr. Carl Shanks, President of the Junior Class, acted as toastmaster. -E. C. 


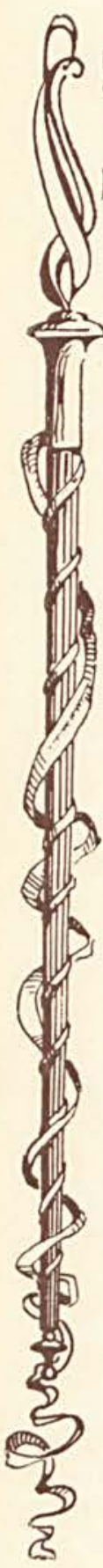

\section{PRESIDENT'S RECEPTION}

Dr. and Mrs. McChesney's reception for the students is a pleasure which we anticipate every Spring, and we can safely say we are never disappointed. Last year it was an unusually happy occasion. Our President and his wife have the faculty of making one and all feel quite at home. The lunch served to a large number of guests was particularly delicious. Later in the evening we sang-old songs and new songs, and everyone carried home the impression of a happy and memorable evening spent in an ideal home.

\section{FIRST PRESBYTERIAN CHURCH RECEPTION}

A vigorous clapping of hands greeted the invitation extended by the Presbyterian Church to the faculty and students to join in a reception on Thursday evening, September 23, 1926.

"A chance to wear my new dress," whispered one girl to another who was sitting beside her in the Chapel.

"Um—some good eats," came a voice from the masculine section of the room.

On the evening set apart for said event a large crowd of eager, fun-loving young people gathered in the church parlors in anticipation of a good time. Did they go home disappointed? If they did, it was their own fault. For after trying to discover the name of the famous person on the piece of paper which was pinned on one's back, and after being blindfolded and handing all sorts of slimy, prickly, wriggling objects to one's neighbor, it was utterly impossible to remain incased in a shell of dignified coldness.

And the refreshments-well, the masculine voice was right,-- they were what are termed "good eats."

At the close of this enjoyable evening, everyone present felt like rising and shouting, "Thanks to the Presbyterians. Long may they live." 


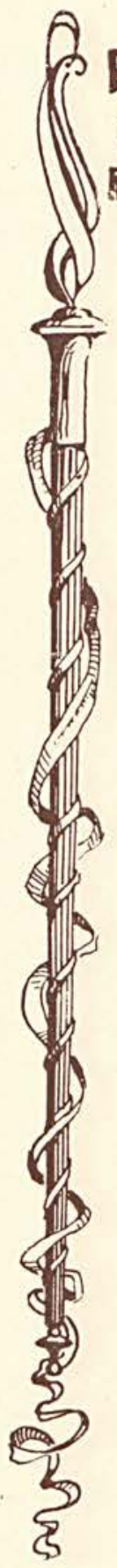

\section{UNITED PRESBYTERIAN RECEPTION}

The letters that went back home that first week were long and varied. There were so many new experiences, new classes, new professors, feeds, athletics, etc.

But the majority of those letters had this one thing in common-they mentioned or elaborated at length on this one topic, "The United Presbyterian Church entertained the students and faculty last Tuesday evening."

Would you like to know what else those letters said about that particular social occasion? No doubt the following is a fair example of many others that made their way back to the home post office that week, consequently we have asked permission to print this sentiment as expressed in the letter:

"The United Presbyterian Reception was certainly a most enjoyable occasion. We're sure everyone had a good time. How could they help it? We had novel and interesting entertainment and refreshments that made home seem near. We feel so much better acquainted with everyone and we know we're going to like college now." M. L. E.

\section{COUNCIL TEA}

One of the very enjoyable social events of the winter was the tea, given January 18th, at the Library Clubroom, by Deans Dolby and Howland, for the House Mothers and other friends. plants.

The club room was very artistically decorated with sweet peas and potted

The Misses Ada McKay and Isabel Clark, members of the Student Council, presided at the tea table.

Music was furnished during the afternoon by the Misses Mae McKay, Ruth Burbick, and Esther Henderson.

Deans Dolby and Howland each made a very pleasing talk in which they explained the work of the Student Council and made a plea for closer co-operation between students, Deans, and House Mothers. 

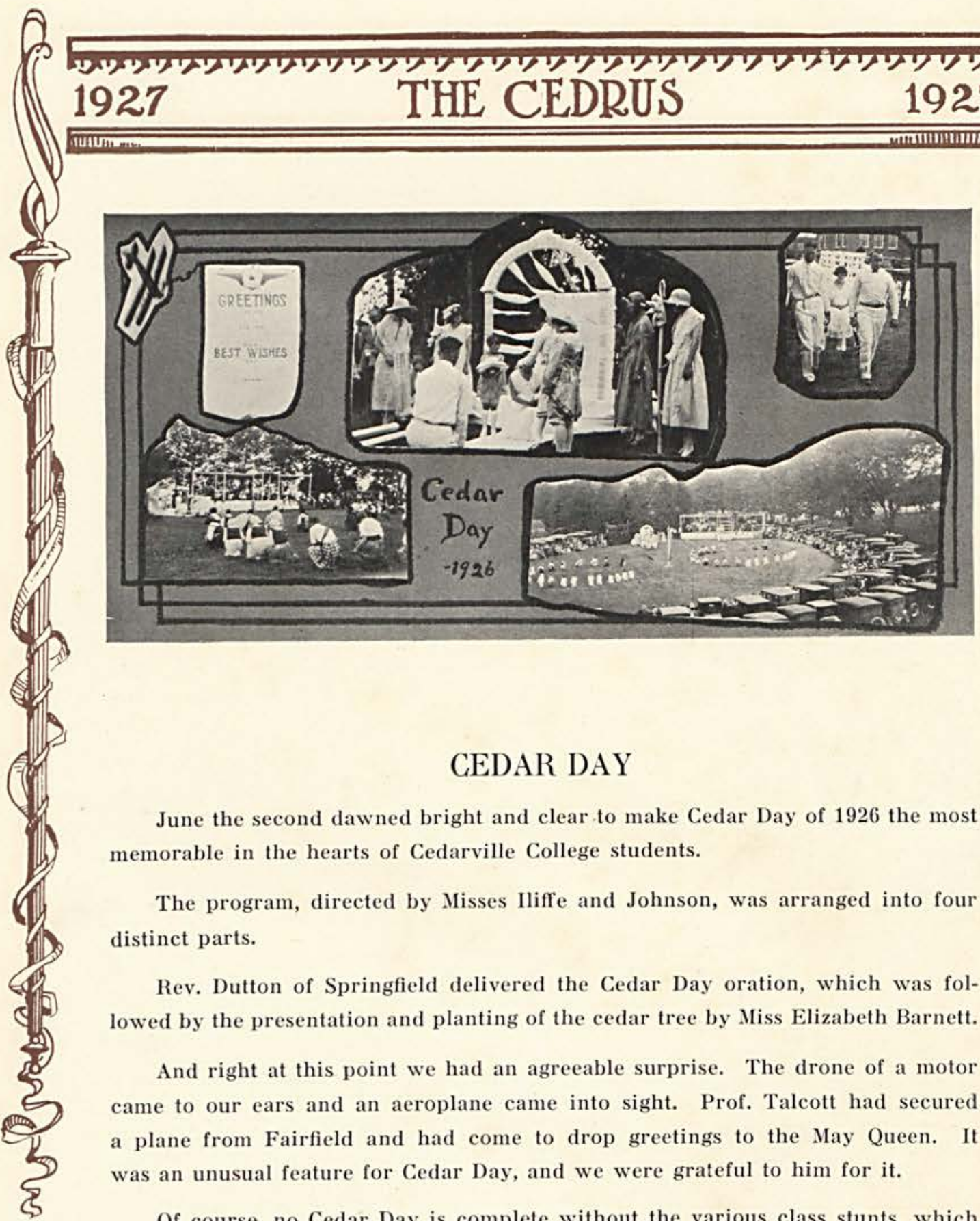

\section{CEDAR DAY}

June the second dawned bright and clear to make Cedar Day of 1926 the most memorable in the hearts of Cedarville College students.

The program, directed by Misses Iliffe and Johnson, was arranged into four distinct parts.

Rev. Dutton of Springfield delivered the Cedar Day oration, which was followed by the presentation and planting of the cedar tree by Miss Elizabeth Barnett.

And right at this point we had an agreeable surprise. The drone of a motor came to our ears and an aeroplane came into sight. Prof. Talcott had secured a plane from Fairfield and had come to drop greetings to the May Queen. It was an unusual feature for Cedar Day, and we were grateful to him for it.

Of course, no Cedar Day is complete without the various class stunts, which were "pulled off" in due order from Freshmen to Seniors. To say the least, the Seniors seemed to believe profoundly that it pays to advertise! Each one appeared, carrying a huge cardboard with some letters of the alphabet and when complete we read, "Ice-Bound," the name of their play to be given that same evening. We only hope that the returns more than repaid the cost. 


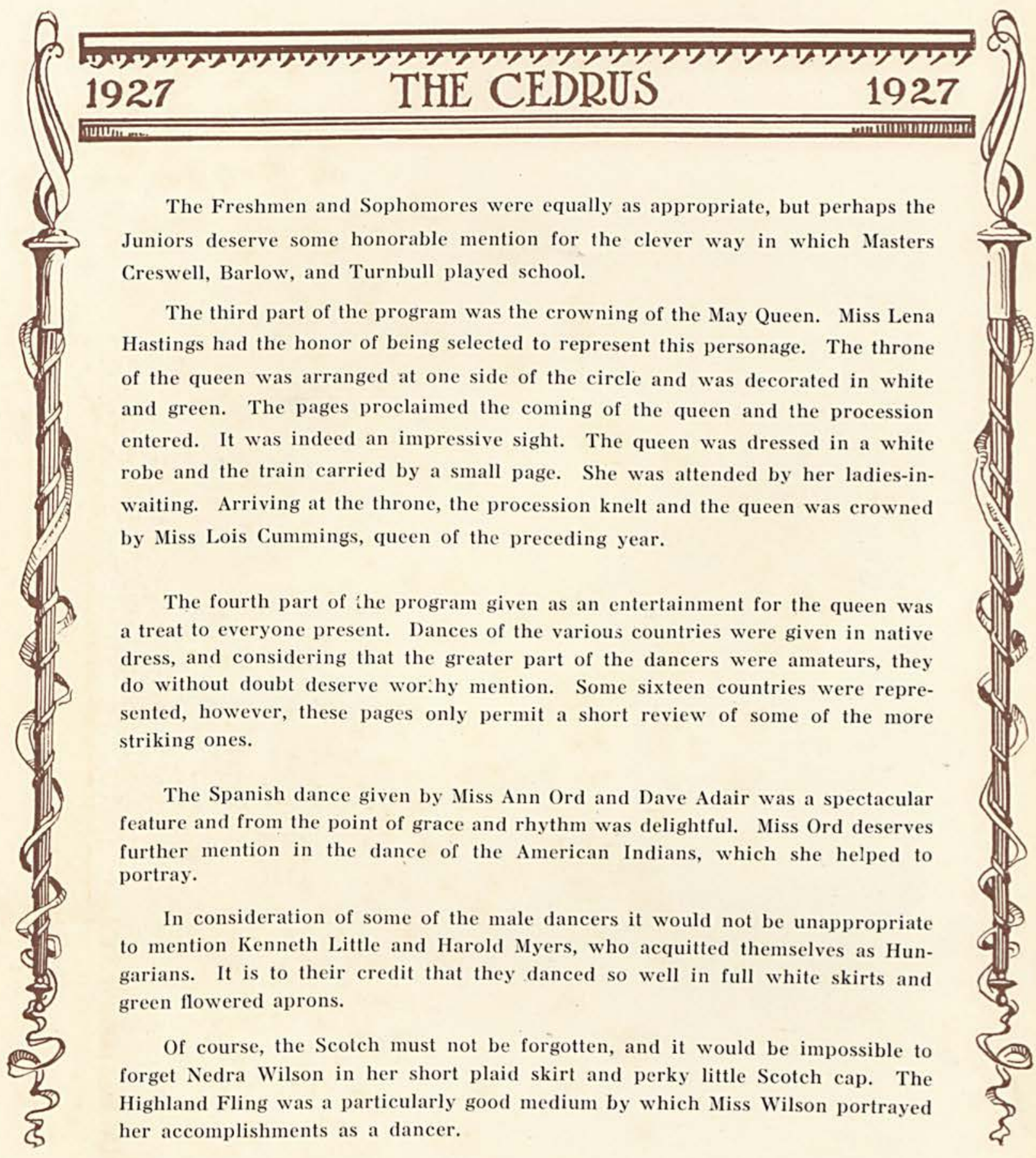

And last but not least we give honorable mention to our football star, Mr. Paul Brown, as a Russian dancer.

The program was well given, and it is to Miss Iliffe and Miss Johnson that the credit is due for the time and splendid training that they gave.

And we only hope that Cédarville College will have many more such Cedar Days as that of ' 26. $-\mathrm{R}, \mathrm{B}$. 


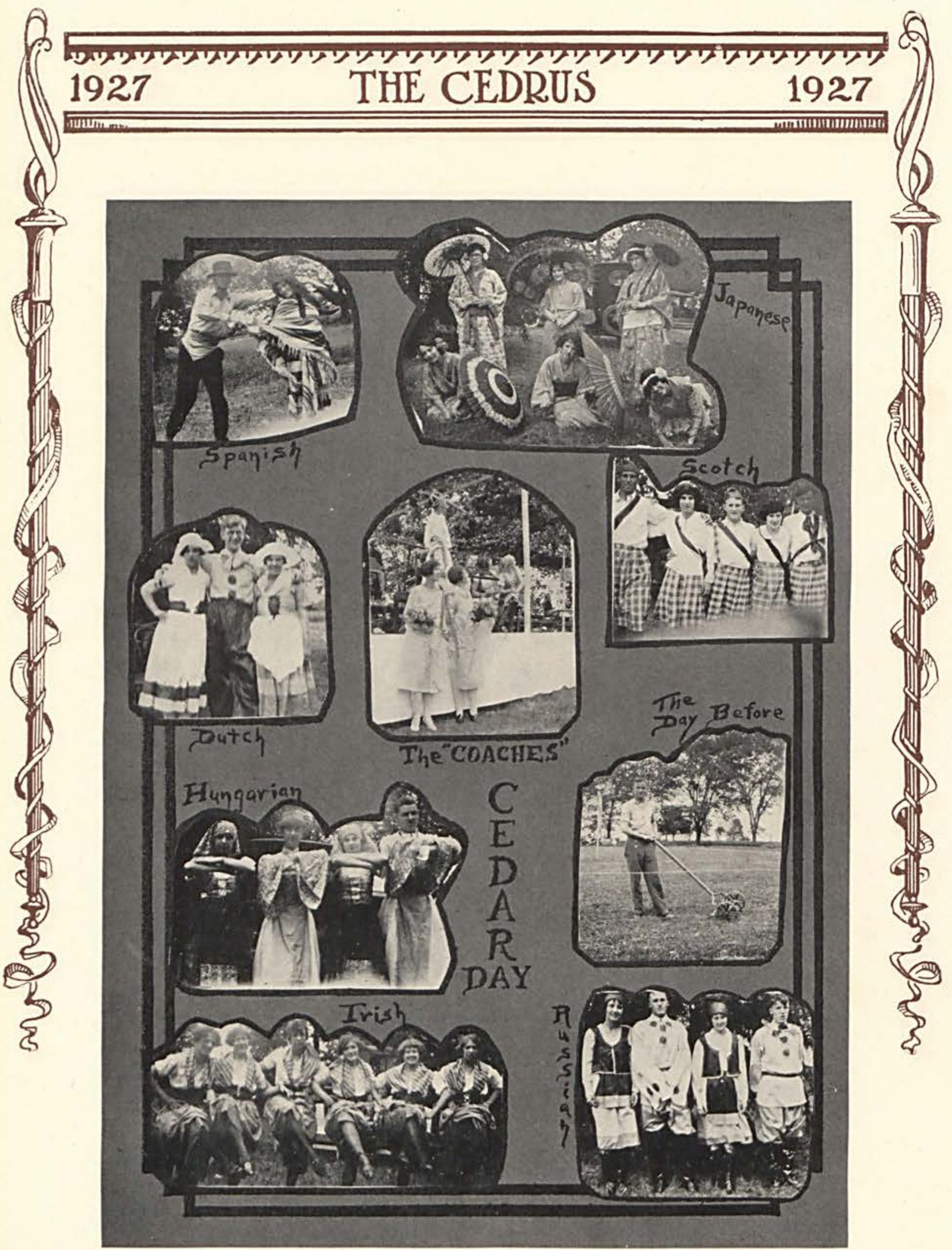




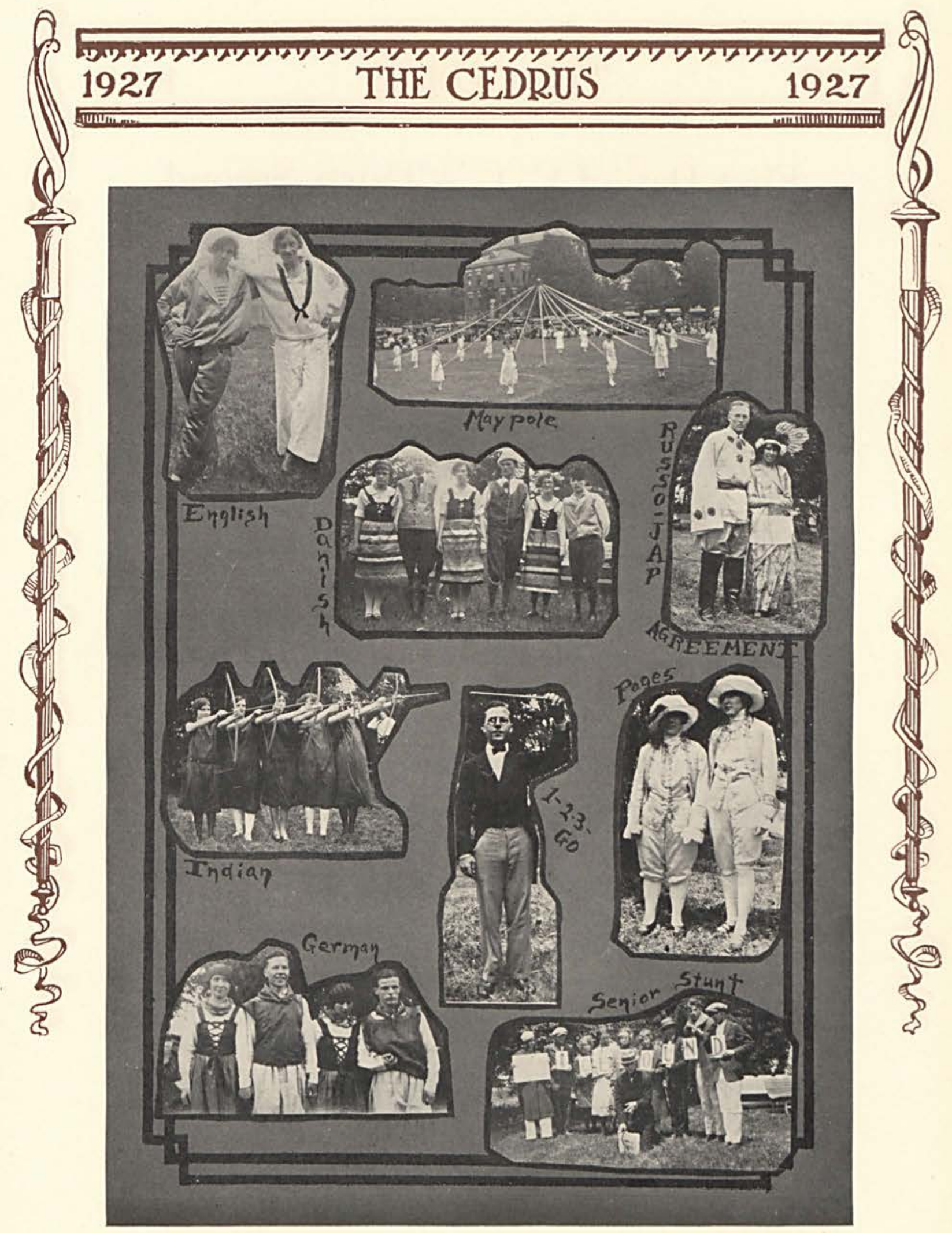




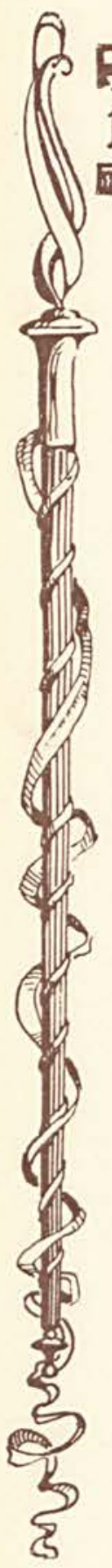

\section{First Day of C. C.'s Thirty-Second Year}

Old Sol smiled on C. C. even more than was his custom this September morn. He saw her students engaged in various activities in this the first day of her thirty-second year. In the morning the formal opening was held in the High School Auditorium under the leadership of our President, Dr. McChesney. The address was given by Mr. Myers Y. Cooper, who was well received by his audience. Numerous announcements, bewildering to some, were made and everyone hastened to the main college building to search out his classrooms, get his assignments, and start the business of getting acquainted.

This was continued into the afternoon, when the older girls and their "Little Sisters" were entertained at a tea given by the Y. W. C. A. This time the library was the scene of groups of college girls with a background of fall flowers in keeping with the orange and blue, and an atmosphere of laughter and pleasure in making new friends.

Really, we were just beginning to get acquainted and the day was not yet complete. Oh, no! for Cedarville is undoubtedly a co-educational school. So that evening "Nagley's Hall" was chosen as the trysting place. The Y. M. C. A. promised to entertain us, and that they didroyally, too, it was agreed. No one could be reserved or bashful for long in the fun of that evening and it was great to meet so many new friends and anticipate the future associations. A feature of the evening, not to be slighted, was the "belling" and the "free-ride-for-nothing" we thought it our duty to give two of the former students of C. C. After bringing down the wrath of almost every Cedarvillian on our heads, for our noise, we disbanded for the night and even the most homesick Freshie as he turned over for the last time sleepily guessed he "could stand it after all, if this was college." 


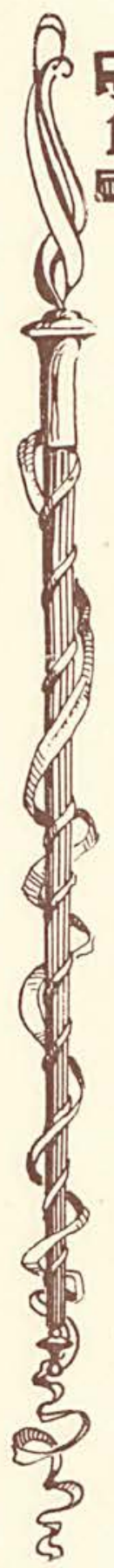

\section{THE BACKWARD PARTY \\ "Backward, turn backward, oh time in thy flight! \\ Let me be back-foremost just for tonight."}

"Tonight" was one cool evening of once upon a time last Fall, and the lines above were the sentiments of a motley throng of Y. W. girls who entered Nagley's Hall by painfully ascending the steep stairway backwards and by backing into the room.

"Motley throng" was correct. Progress was not aided by the misfits in the girls' clothes which, even though they were on their rightful owners, crowded at the neck and bagged in front. There was no possibility of a social misfit; if any wished to sit down she must be a wallflower, for all the seats and even the piano were modestly "stood in the corner" with the useful part toward the wall.

Lots of "tail-light first" games were played, such as a backward spelling bee, a contest in which every side must do what it was asked backwards, a shoe contest, and others.

And then came the eats which were saved from the hands of would-be marauders who did not belong but who were not at all backward in coming in the back way. But their attempts were foiled by dint of other cleverer brains than theirs.

Then the girls backed down the stairs and walked home. Let's hope they've lived happily ever after.

$$
\text { -F. M. }
$$

\section{VALENTINE PARTY}

"Oh, tell me, dearest heart of mine, That you will be my Valentine."

Each February brings a day of hearts and happiness. St. Valentine's Day of this year will be long remembered for its jolly time in our gymnasium.

The joint Y. W. and Y. M. gave a most successful party for the students and faculty. In the course of the evening everyone participated in some sort of game and enjoyed himself to the utmost. Both sentimental and comic valentines were exchanged. The boys held the honor of giving the largest and most sentimental tokens. We realize our girls are extremely bashful on such occasions. After several hours of fun we were served a delicious lunch. Each one of us departed, guarding our precious valentine that we might stow it away among the already crowded pages of our memory books. 


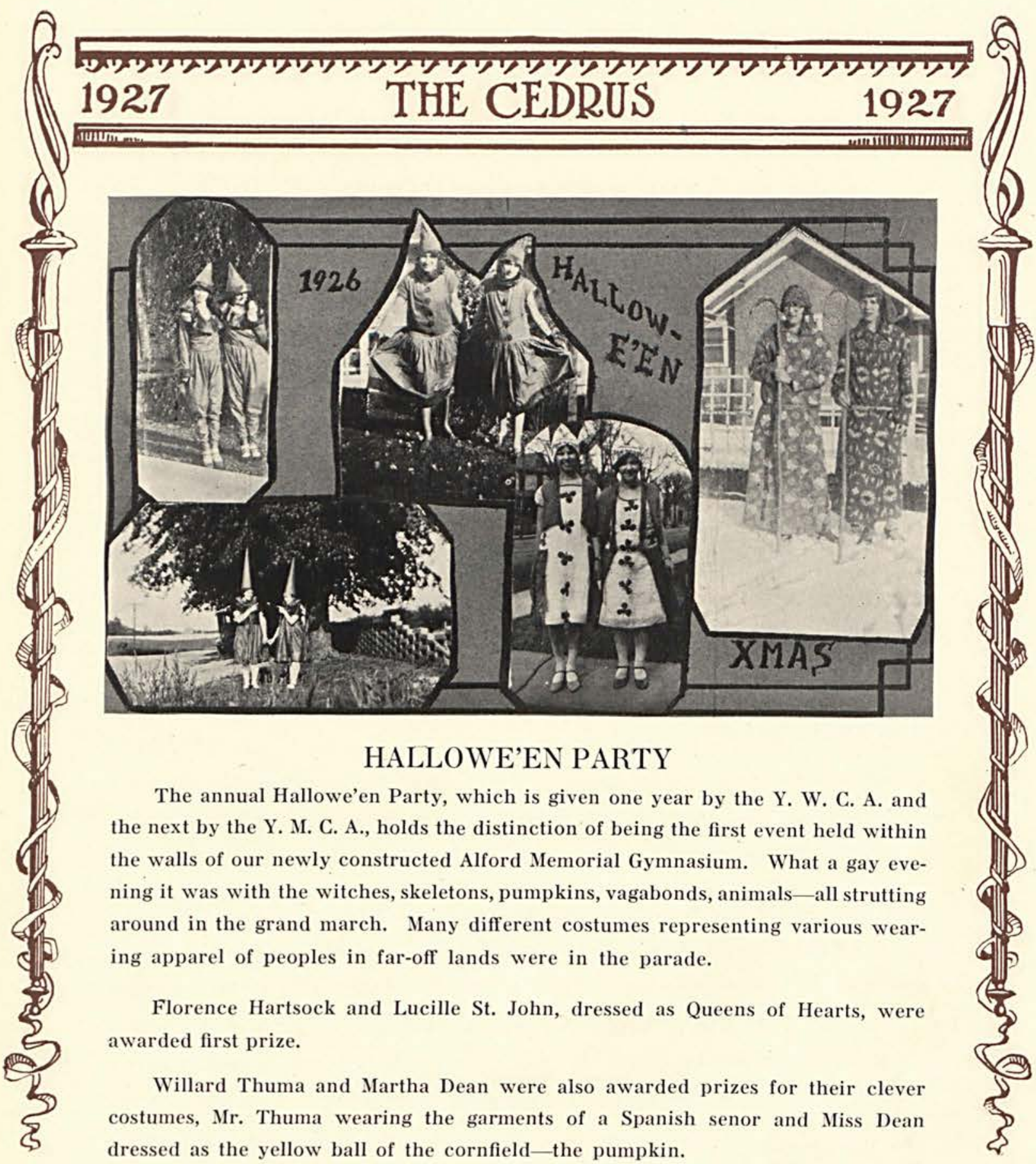

Then came the most interesting part of the evening - the "eats." There were large hamburgers beside a mountain of salad and a pickle. Plenty of cider prepared us for the pumpkin pie which was almost covered with whipped cream.

The girls' party this year proved to be the biggest and best of all Hallowe'en celebrations held heretofore, and it established a standard for future "Y's" to attain in giving such entertainments.

-D. M. 


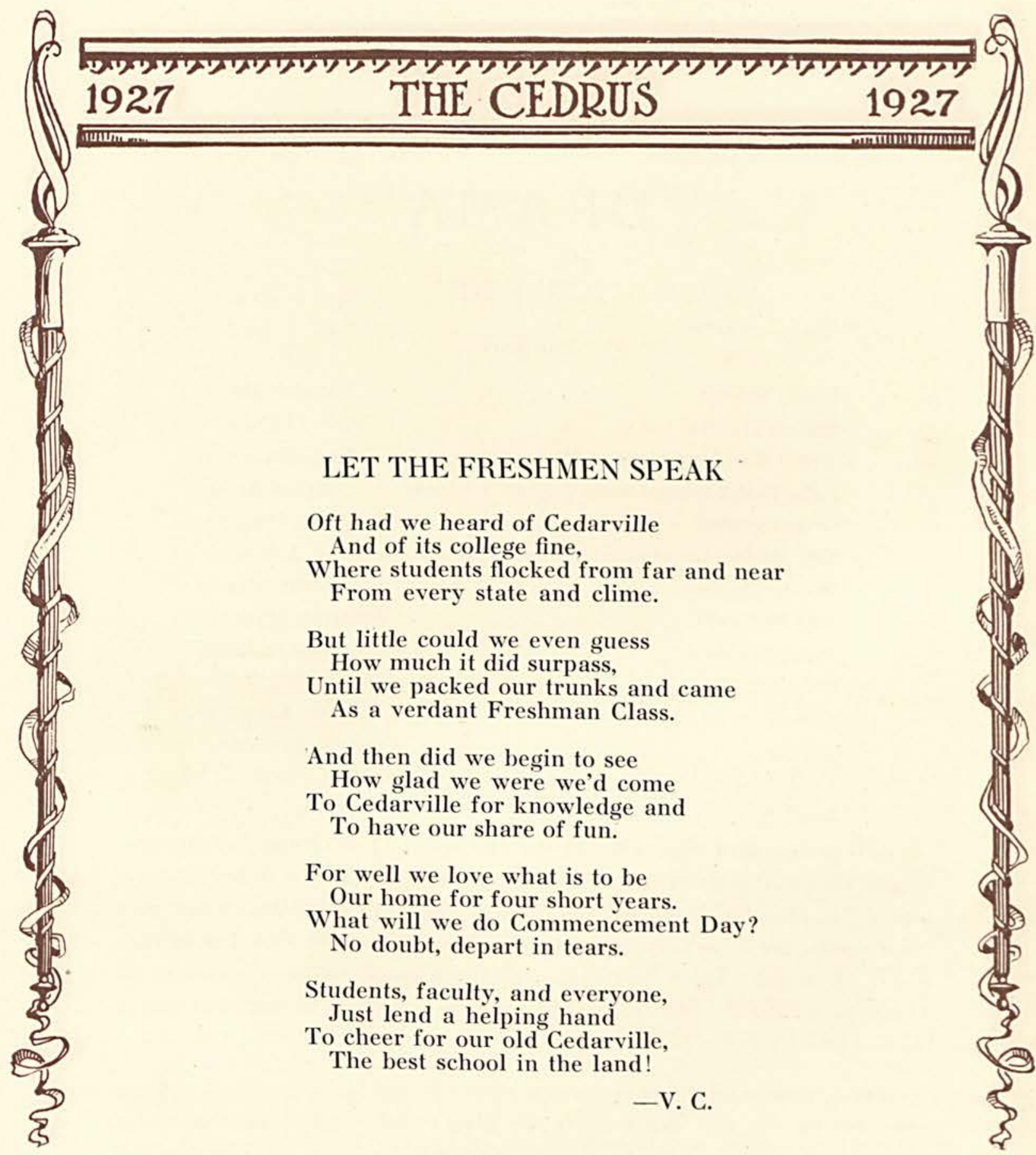




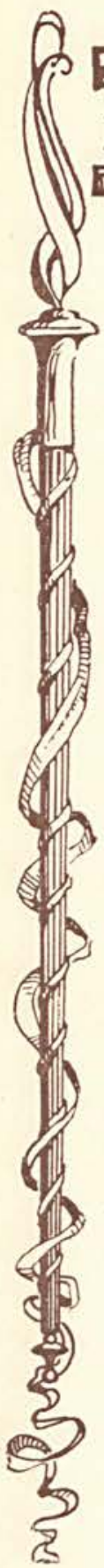

\section{THE CEDRUS}

\section{"ICEBOUND"}

\section{The Cast}

Henry Jordon . . . . . . . . . . . . . . . Marston Hunt

Emma, his wife.

JUNe THOMpson

Nettie, her daughter by a former marriage

Lena Hastings

Sadie Fellows, once Sadie Jordon, a widow

Ethel Beals

Orin, her son

Ruth DobBins

Ella Jordon, the unmarried daughter

Lucile ANderson

Doctor Curtis

Harold Myers

Jane Crosby

Winifred Stuckey

Judge Bradford

Henry Kyle

Ren Jordon

Donald FunK

Hannah

Freda Crowell

Jim Jay

Charles Townsley

It is always with some difficulty that the Senior Class chooses the play that is to be their final performance and their lasting impression upon those they leave behind. In choosing "Icebound," the Class of '26 used rare judgment and great intuitiveness, and it can be truly said that it left an impression which time will not erase. "Icebound," which was written by Owen Davis, has been presented on Broadway for the last two seasons and has been acclaimed by critics as one of the best plays in recent years.

Those Seniors appearing in the cast were splendid in the portrayal of their parts, but the one that stands out in our mind is the excellent performance of Donald Funk as Ren Jordon. Mr. Funk very well portrayed the wayward son against whom the world seemed to have a grudge. The death of his mother brings him home again and he is persuaded to stay and run the farm. Under the tutelage of Jane Crosby, played by Winifred Stuckey, he "finds himself" and settles down to lead a useful life.

The Class of '26 has left an enviable mark for future Senior classes to reach. Due to the efforts of the class and the careful coaching of Miss Dolby, the play standard of Cedarville College has again been raised.

J. M. 



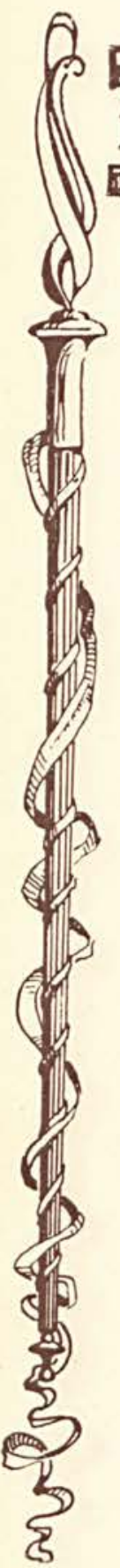

WITTENBERG AND CEDARVILLE IN DEBATE

Who remembers the time when intercollegiate debates were in vogue at Cedarville College? For a number of years our department of Public Speaking has not functioned in intercollegiate activities. Talent that might have been utilized to bring glory to Cedarville has long been neglected: its value has not been recognized. However, "It's a long road that has no turning." During the first semester of this year a proposal was received for Cedarville College girls to meet Wittenberg College girls in dual or triangular debates. "She can who thinks she can." Though the proposal came from a big sister college, enough of our girls thought they could hold their own in such contest, but a change in Wittenberg's schedule prevented the realization of our hopes in regard to a girls' debate.

Early in the second semester a similar proposal came for a men's contest. "He can who thinks he can"-our men thought they could, and they did. On March 28th teams from the two colleges met on the proposition, "Resolved: That the Direct Primary Should Be Abolished."

A negative team, composed of Messrs. Willard Barlow, John Johnson, and Harvey Auld met the Wittenberg affirmative team at Wittenberg. The men were cordially received and a fine audience was present to inspire the debaters on both teams. Wittenberg's negative team came to Cedarville to meet our affirmative team, composed of Messrs. James McMillan, Paul Orr, and Robert Turnbull. Alford Gymnasium was well filled by those who are interested in all our college activities. The contest was not a disappointment to anyone, for our debaters took their parts with credit to themselves and honor to their Alma Mater.

The "no-decision" open forum plan was followed. Members of the audiences were given the opportunity to ask questions, bearing on the proposition, of any member of either team. Although there were no judges to render formal decisions, we feel assured that in the presentation of argument the Cedarville teams did not occupy second place.

The debates were entered into with such earnestness by all participants and aroused so much interest in this type of intercollegiate activity that plans will likely be made for similar contests next year.

-B. E. R. 


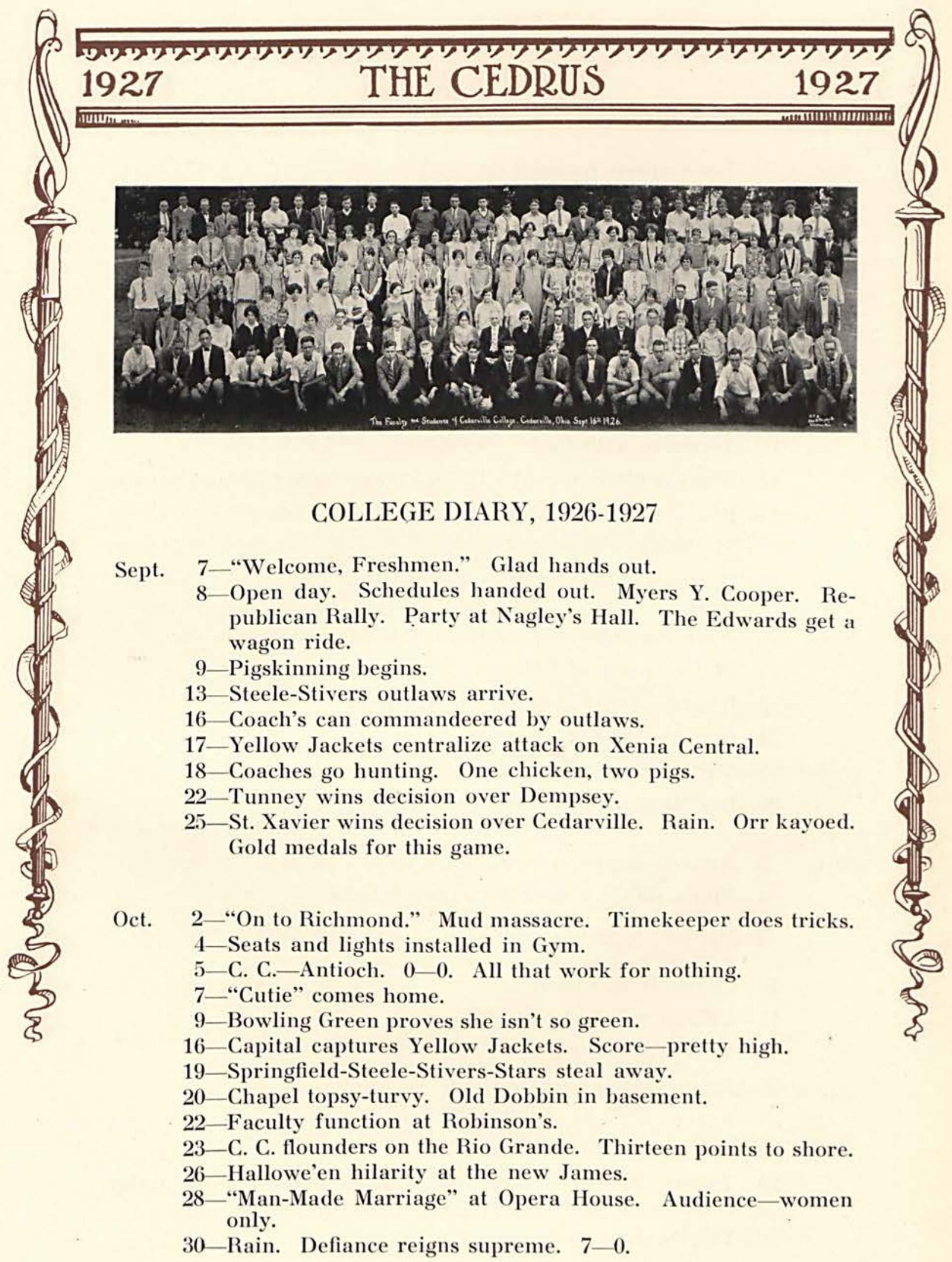




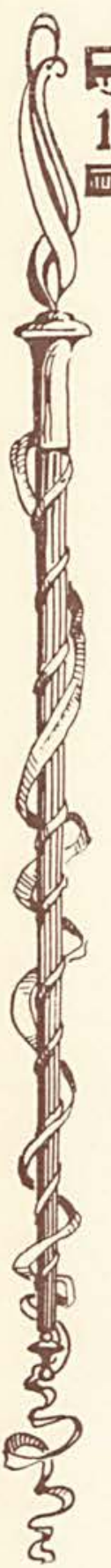

Nov. 1-Town square rounded up.

2-Election day. Y. W. tag day. Myers Cooper tagged out. Dramatic Club organized.

3-Dramatic Club practically disbanded.

4 -Ditch diggers mutilate campus.

5--Borst and his shotgun miss a dog at four feet in Doc's back yard.

6-C. C. misses Antioch by four yards. Score 7-6, or was it $2-6$ ?

11-Armistice with Profs. No school.

12 - Bluffton bluffs us out. 17-2. Forty-eight paid admissions.

15 - Bunny law in. Ramrod day for the Nimrods.

17-Pig law in. Marvin slays one. Barbecue at Bank Building.

18-Dampness discovered in Science Hall gas pipes. Probably frost.

21 - Bible reading frost.

22-Philad. party at Collins'.

23-It seems Smith gave an English test.

24 Give thanks for vacation.

25-Turkey day.

26-Doc Richards meets one one-gun man.

Dec. $\quad 3$-Alford completed and baskets up.

4 -Rike's reindeer here for college kiddies.

8-Gym unofficially dedicated. Unofficial score: C. C. 28 "Äntiark" 17.

10 -Penna. R. R. wreck.

11-Urbana wrecked. $24-22$.

$19-Y$. W. Cantatter at 1st Pres. Kirk.

20 - Juniors Hang a Goose High.

21-Again. C. C. 14 -Bluffton 26.

22 -Kris Kringle kloses kollege.

25-Today's the day — diamonds - spinette desks - candy - cedar chests - golf clubs - gold coins 'n' everything.

29-Varsity ducks Defiance: 37-18. 


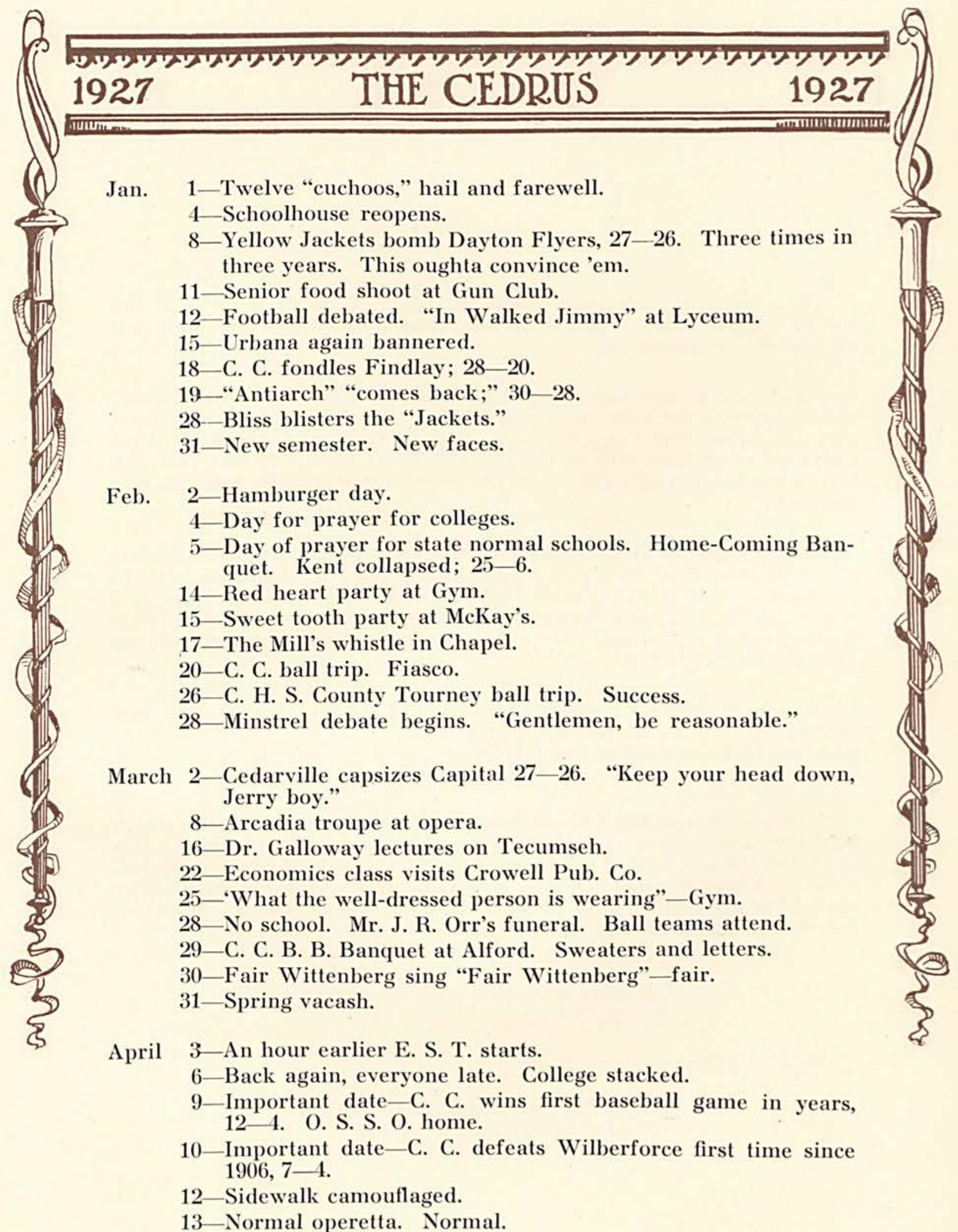

-Elmer Jurkat. 


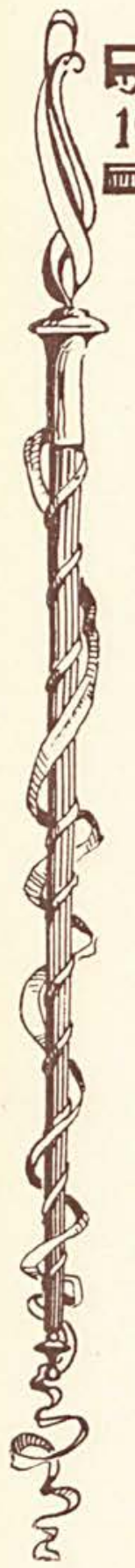

\section{CURIOSITY}

The saying is "Curiosity killed the cat." Perhaps it did. If the results are not always as dire as that may indicate, at least they are very often embarrassing.

I had gone to visit one of my friends for the afternoon. She stepped out of the room for a moment, and it was then, while my eyes wandered over the room, that I saw the box. For my own sake, I may say that I was not more than nine or ten years of age, I think. At any rate, the box attracted my attention and my feminine curiosity was at once aroused.

As I remembered it, the little cube was not more than two inches in width and three inches in height and depth. It seems, as I try to recollect it, that it was a pale blue box. But there was a cover and it was tightly fixed. Ah, there was the cause for my discomfiture. What possibilities it contained! My gaze and desires were centered, not on the box, but its contents.

I looked about me. My friend could not see me. No one else was in evidence. If I raised that lid and looked into the entrancing box, who would know? Was I entertaining ideas of deception? Perhaps. But wait!

I advanced brazenly, but cautiously. There was a small catch which held the cover down. I fingered this. Then I loosed it. Whiz! Up came the lid and with it a cry that could be heard all over the downstairs. I stared dumbly at the Jack-in-the-Box which had arisen before me. After my first surprise I was terribly chagrined to hear, against all hopes, the laughter of my friend. Someone said,

\section{"Oh, what a tangled web we weave \\ When first we practice to deceive!"}

Might I add-

"How great, how much is our chagrin

When boldness gets to look in!" 


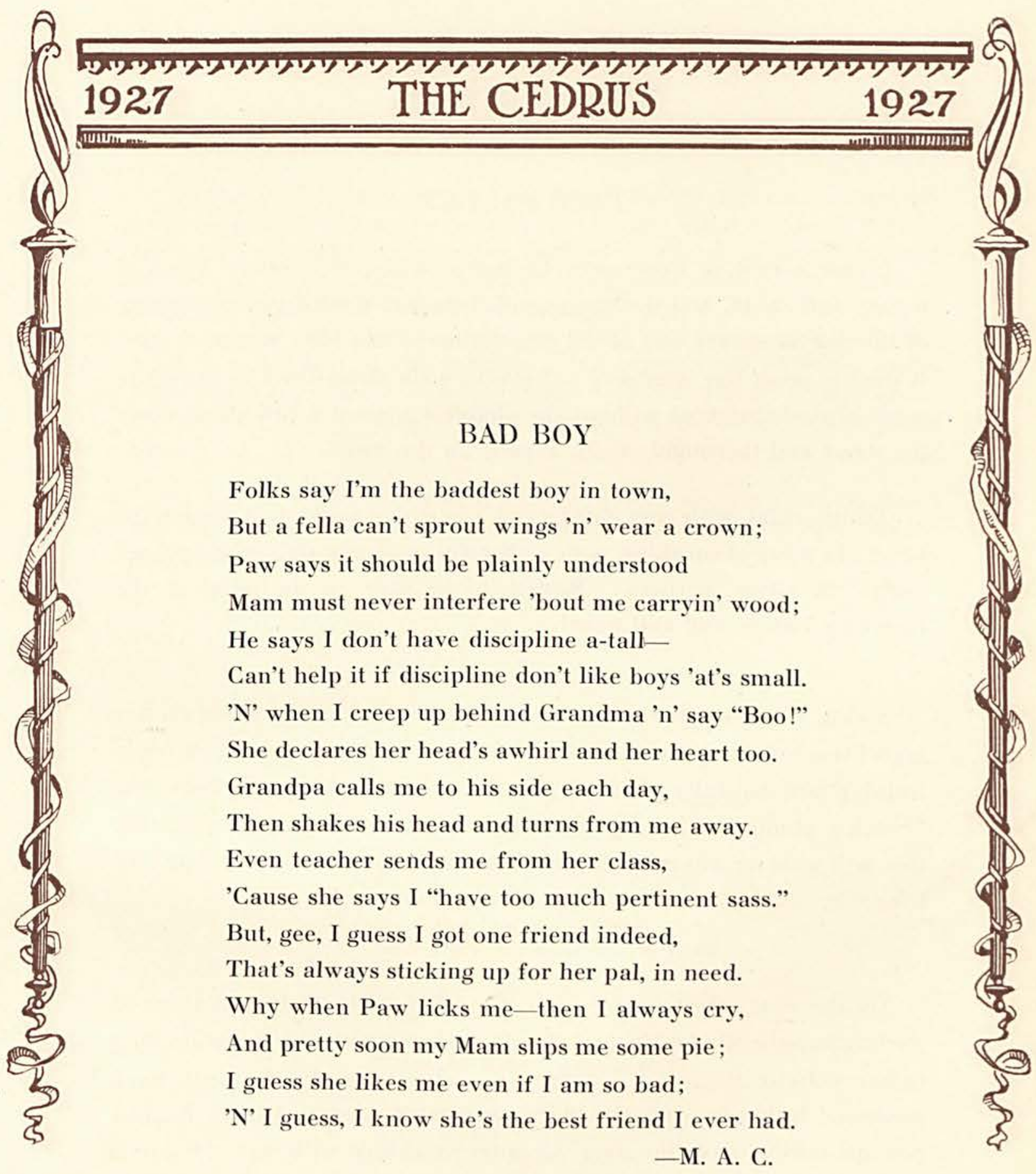




\section{FACE VALUES}

In our course in Economics we are studying the various types of money and credit, and the analysis of these has started me to thinking of the mortal money and credit circulating in this busy world of ours. It used to seem like drudgery to have to walk down town to attend to some errand, but now without the slightest pretext I can stroll down the street and thoroughly enjoy myself on the way.

A little child, with rosy cheeks and a beaming smile, that warms the heart like a ray of sunshine, nods a cheerful good-morning as she passes. Gold! Or silver, perhaps! Minted, to be sure, in the mold of the Heavenly Father and still pure!

A chic young teacher with a smiling, jaunty air clicks along on her high French heels. The real self is covered with a veneer of worldly training and carefully polished with the dainty little mannerisms. As I catch a glimpse of her fresh young face, however, I am assured that this is a gold or silver certificate that has full value in the bank of life.

On the next street corner a woman of perhays forty-odd years is waiting impatiently for the bus. She is swinging her arms and grumbling rather volubly to herself. Whatever natural beauty she may have possessed is hidden beneath the cosmetics of worldly beauty daubed promiscuously upon the face already wrinkling with age. I guess, at once, that this must be a duplicate of the rare "greenback" of 1890 , which was issued without metal backing and which was for so many years irredeemable in coins. Yes, as I look closer I am convinced that this currency has been irredeemable for quite a long time, but I am also convinced that, with the proper investment of friendly attention and kindliness, it might be made convertible. 


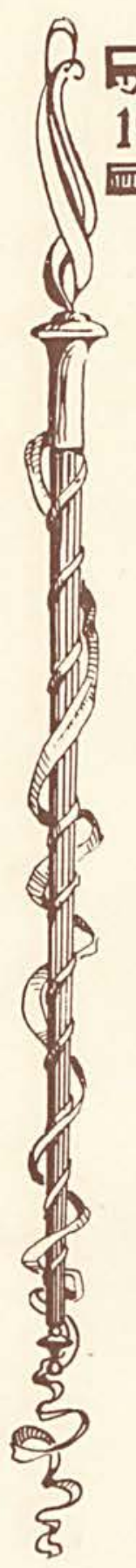

As I near the end of my stroll and am thinking that I have certainly seen enough of human interest to occupy my mind for some time, I see a little old lady attempting to rake up the leaves in her front yard. She is old and bent and her face, deeply furrowed by the plows of Time and Care, still radiates motherly kindness. Now and then, in the course of her laborious task, she stops and leans upon her rake, while a truant tear or two falls upon her gnarled and withered hands. Some wayward son has so heavily drawn upon the heart of that loving mother that now the face value of that ebbing life is only a mortgaged soul.

As I have shown in these few illustrations, so every face registers the value of the life of its owner and the world judges each life by the stamp of its value.

\section{COLLEGE LIFE}

Talk about the good old times

When we were very small;

Just in the lower grades

And knew nothing much at all.

Talk about our high school days

When we were very gay,

And had no cares whatever,

But were happy all the day.

But better than all of these,

With all their fun and strife;

Best of all the times we've had

Is the good old college life. 


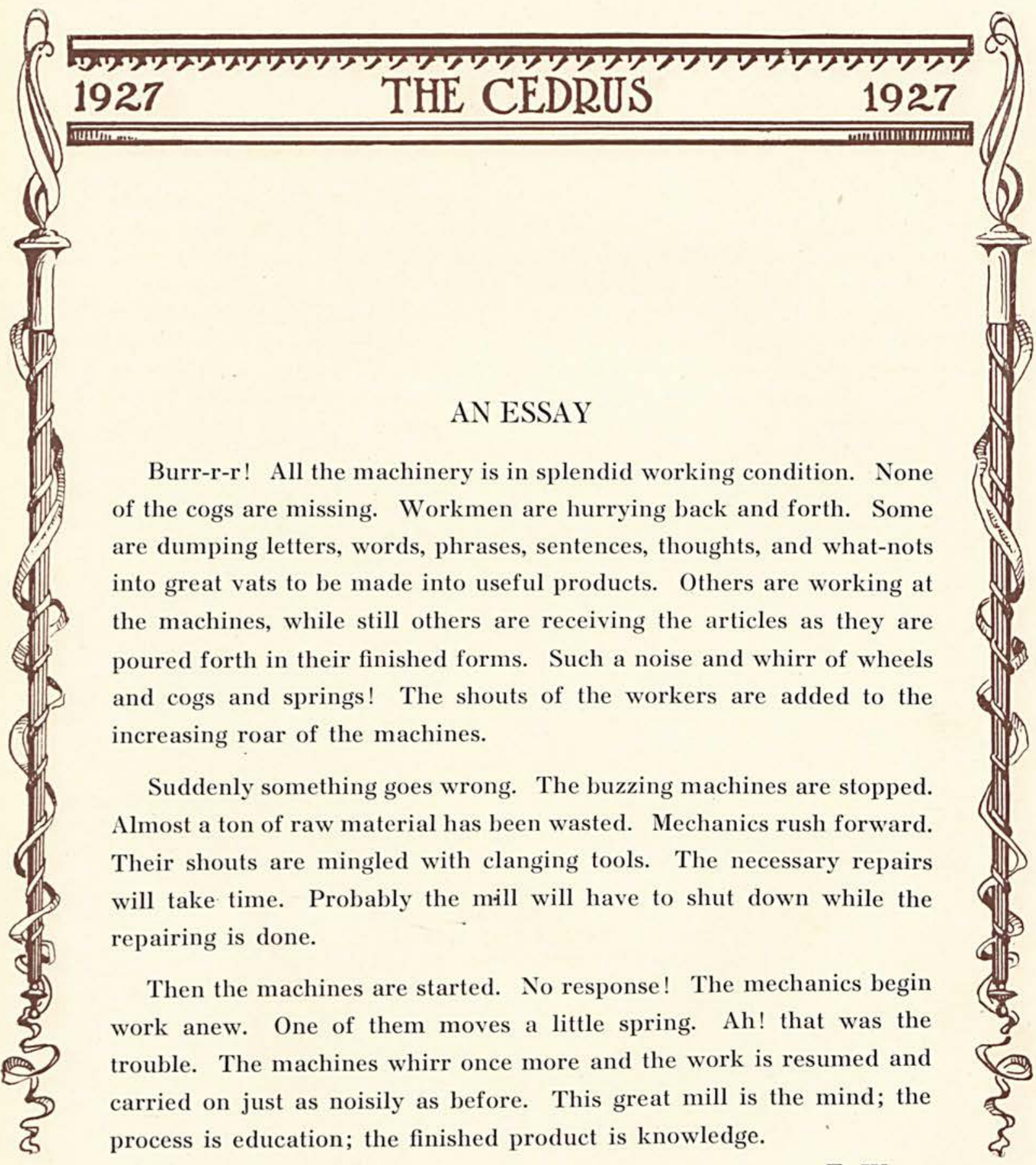
-E. W. 


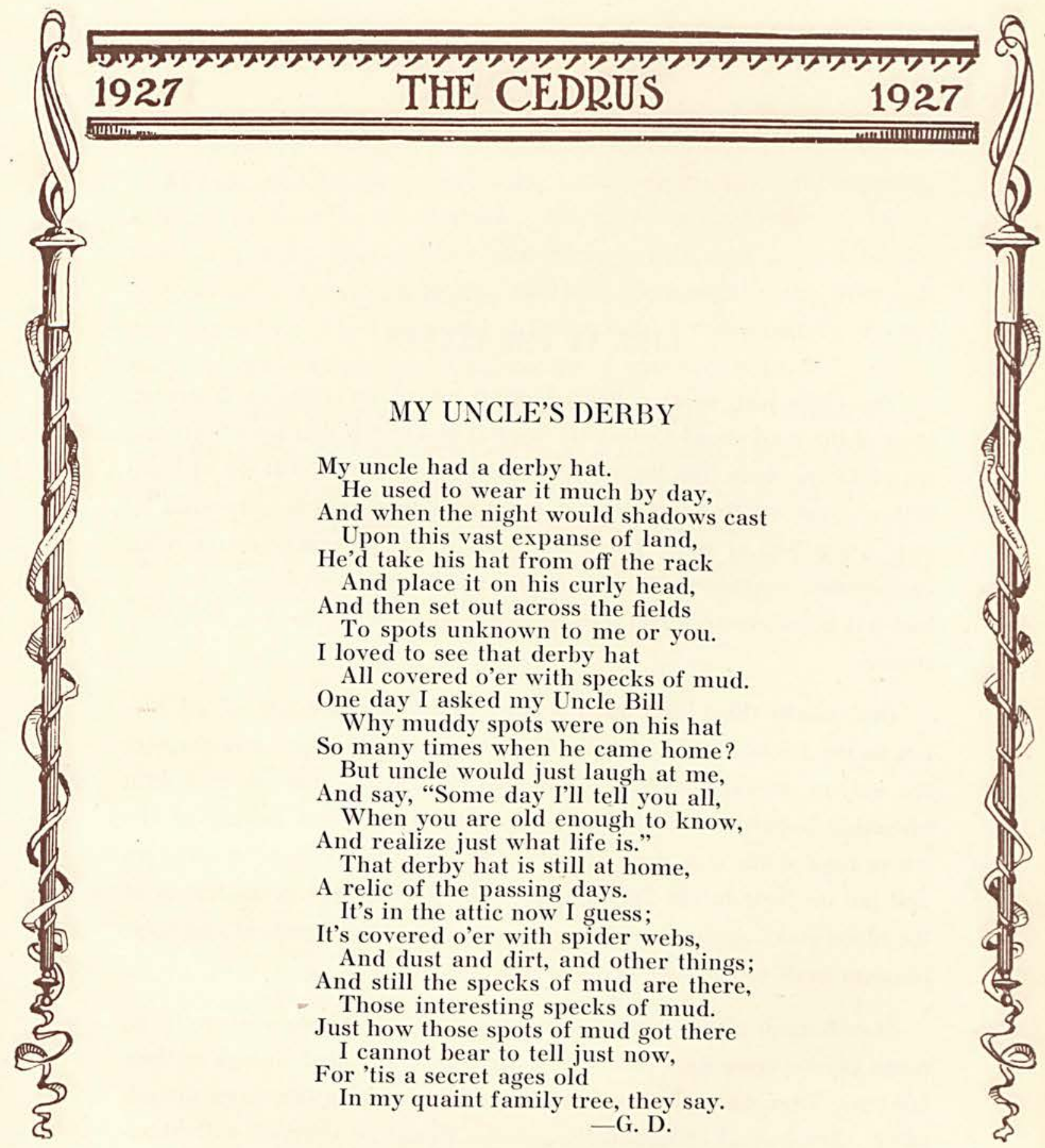




\section{LIFE AT THE CLIFFS}

The cliffs just west of town remind me of an oasis on a desert. Most of the land about Cedarville lies flat and fertile, but upon entering the cliffs one finds that the creek has cut a channel to a depth of from fifteen to twenty-five feet through solid limestone, which is covered by only a few feet of soil. The south bank of the stream looks as if an earthquake, centuries ago, had upheaved the surface of the land and had left great crevices and passage ways between the broken layers of stone.

One would think that such a place would be desolate of all life, but as my friends and I clambered over the rough stones and through the narrow passage ways, I found that the ground was covered with blooming hepaticas which had sprung up at the first calling of the warm rays of the sun, and whispered to the other flowers to wake up and put on their bright Spring garments. Already the green leaves of the blood roots, spring beauties, and anemones had appeared and their blossom buds were forming.

How human is this wild plant life! A few individuals venture forth, make encouraging discoveries, and then shout the glad tidings to their friends. Then comes the rush of the masses seeking life more abundantly. Ere long, I imagined the ground would be covered with thousands of plants trying to make the most of life. Even the steep walls of stone, my friends informed me, would be covered with ferns and moss in the summer time. 


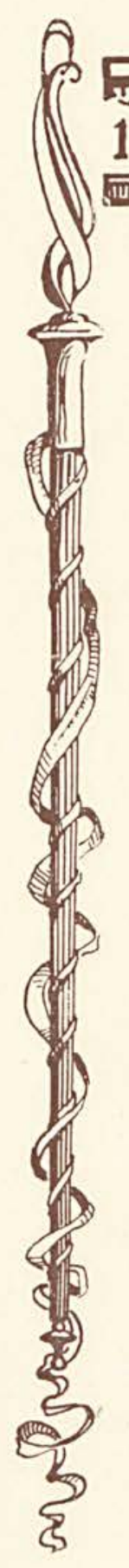

As I scanned the bleak gray walls, I discovered a beautiful hepatica, nodding its head in the sunlight, high up on a tiny ledge of stone. Perhaps a sharp gust of wind had borne a tiny seed to that barren spot, where it had clung firmly, and had taken root in the little soil that was there. It had labored and grown until it now stood sturdy and beautiful, an example to the thousands of plants beneath it.

Quite often a member of the human family, by faithfully and earnestly using the resources that he has, rises to a plane high above that of his comrades, and becomes a leader of men. From this little hepatica I learned anew that those things which seem to hinder and over-burden one, are often the means by which he becomes more sturdy and more useful to those about him.

-C. F.

\section{FRIENDS}

Acquaintances are like the clouds so white, Blown by strong, gay winds to and froSwiftly passing forever from our sight,

We say, "Good day, good-bye," and then they go.

Chums are like the green leaves of Spring,

Coming at intervals, staying a day,

Leaving without warning when they cease to cling, From the hungry tree they flit away.

Friends are like white marble pure,

Ready for service and trials anew,

Cut and polished, stable and secure-

Tell me, what kind of a friend are you?

-M. A. C. 


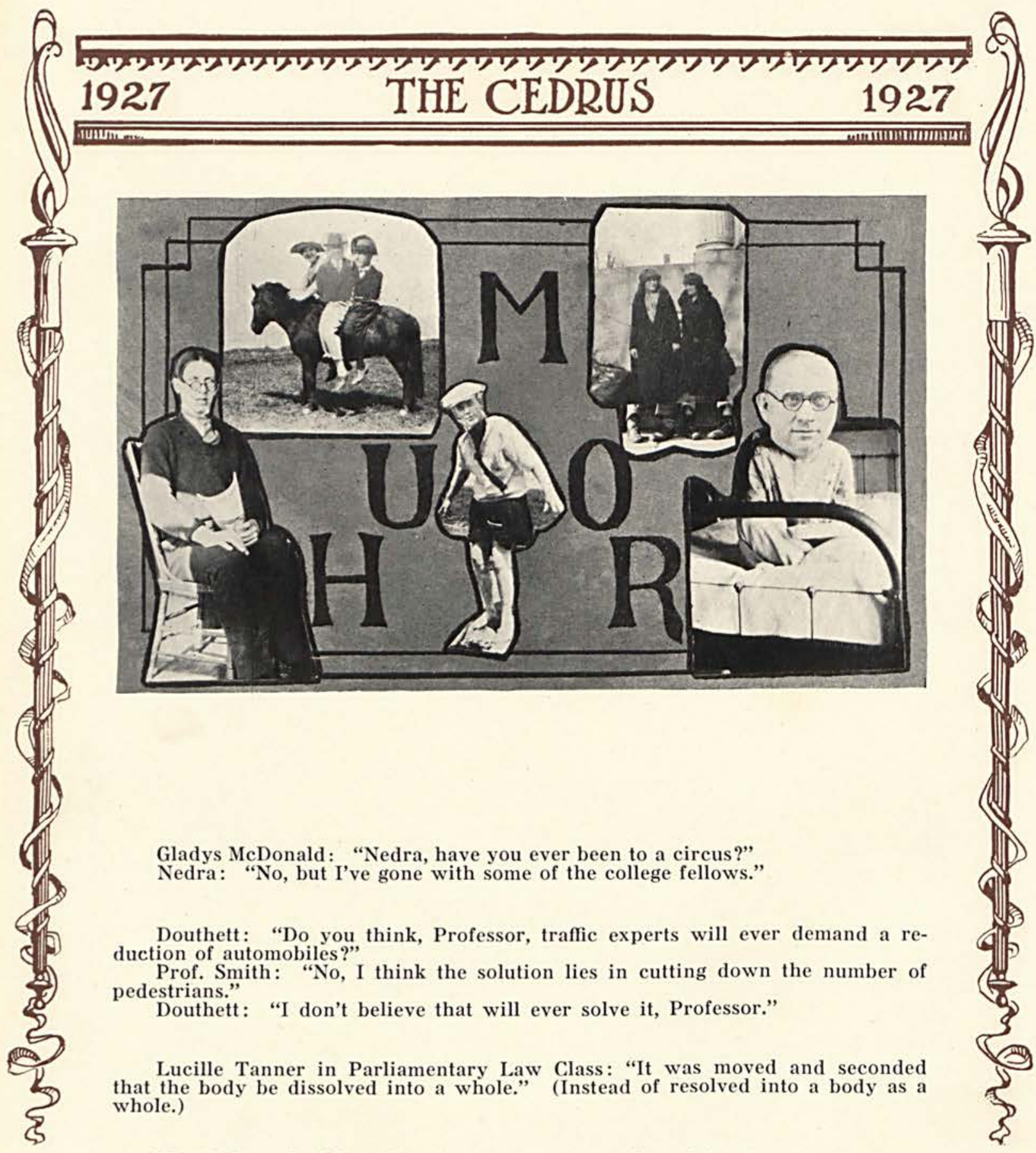

Miss Dolby asked for a description of some member of the Rhetoric Class.

Jean Marton: "Do you want them described from the outside?"

Miss Dolby: "Yes, Jean, you may omit the internal structure." 


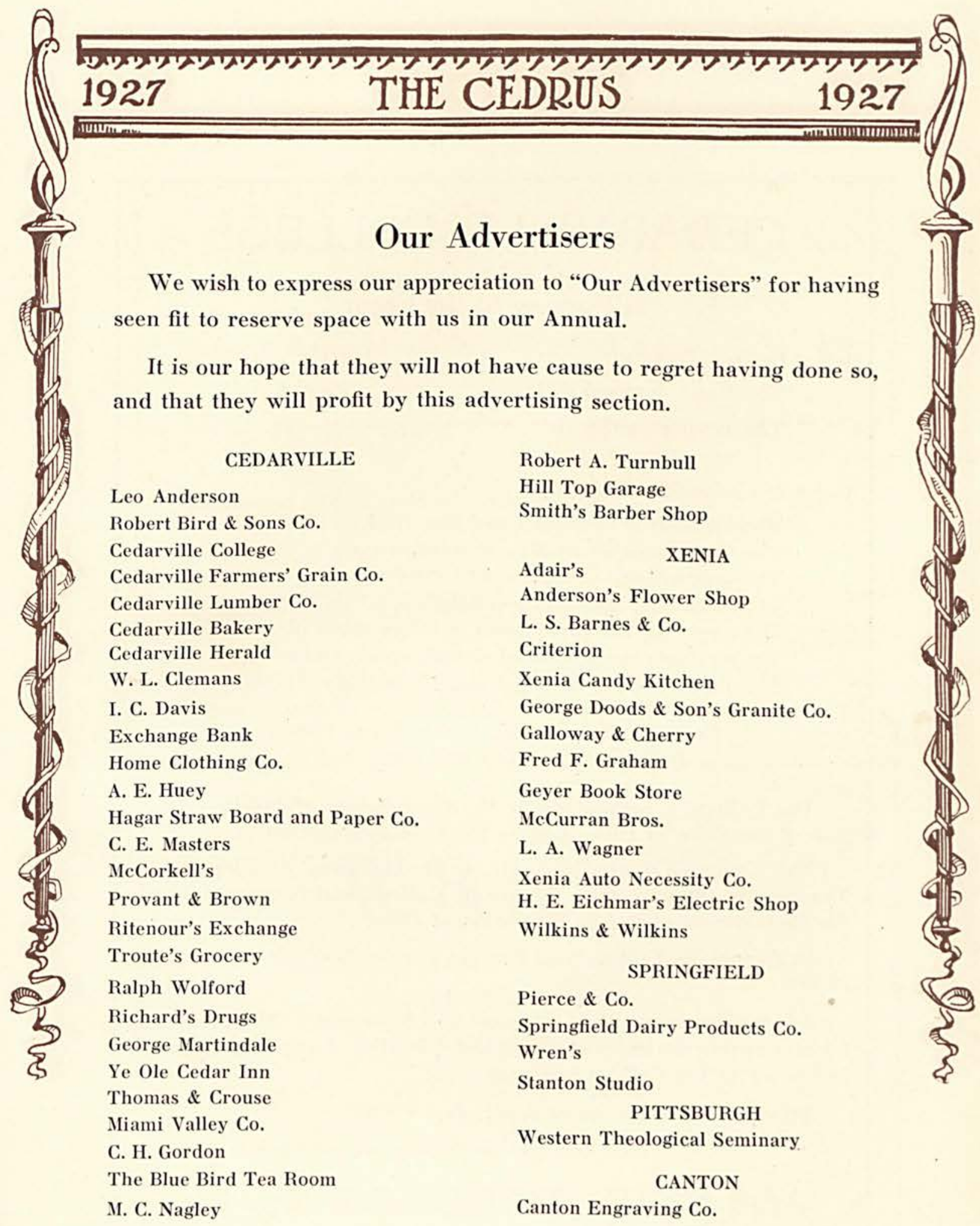




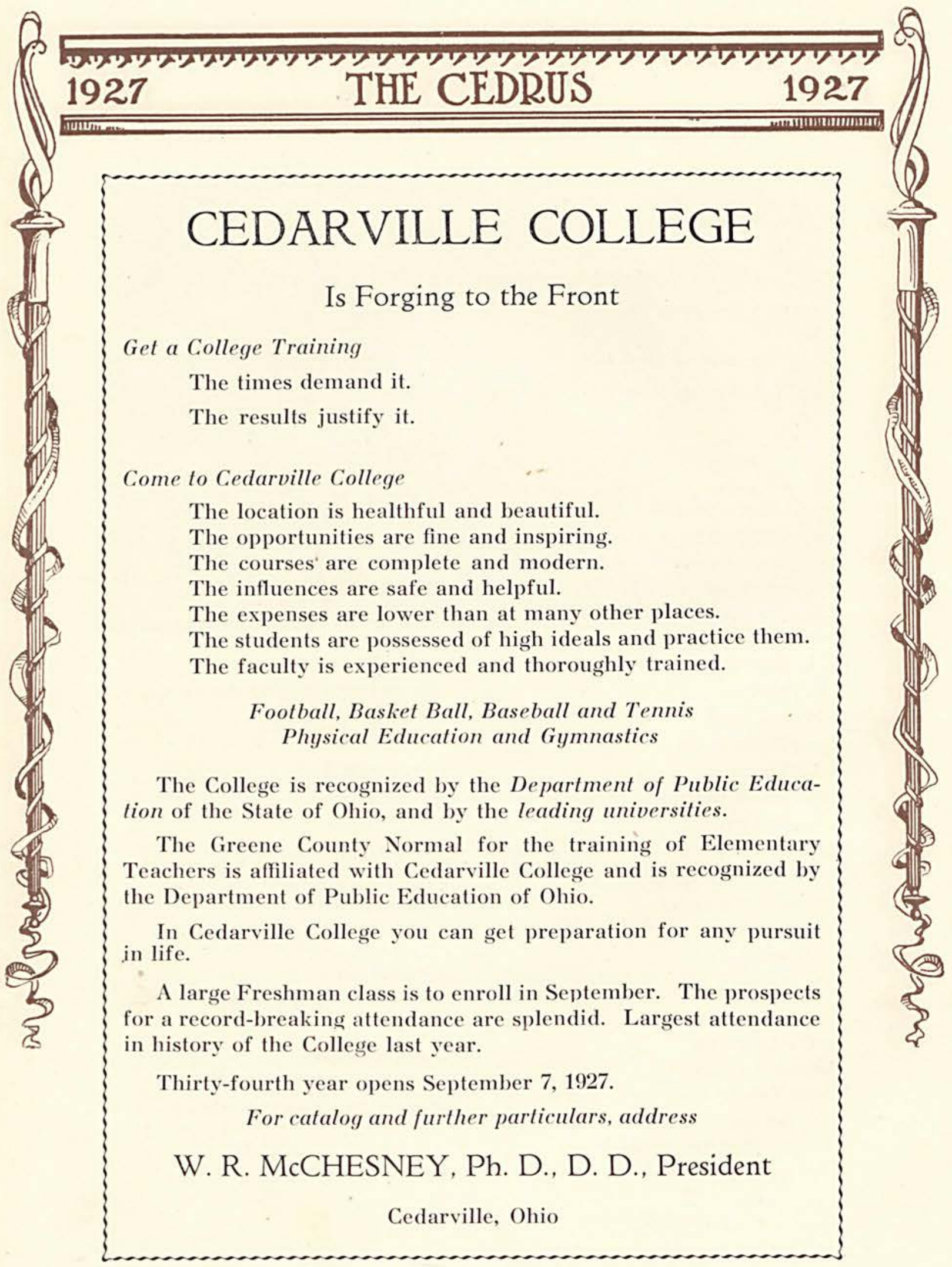




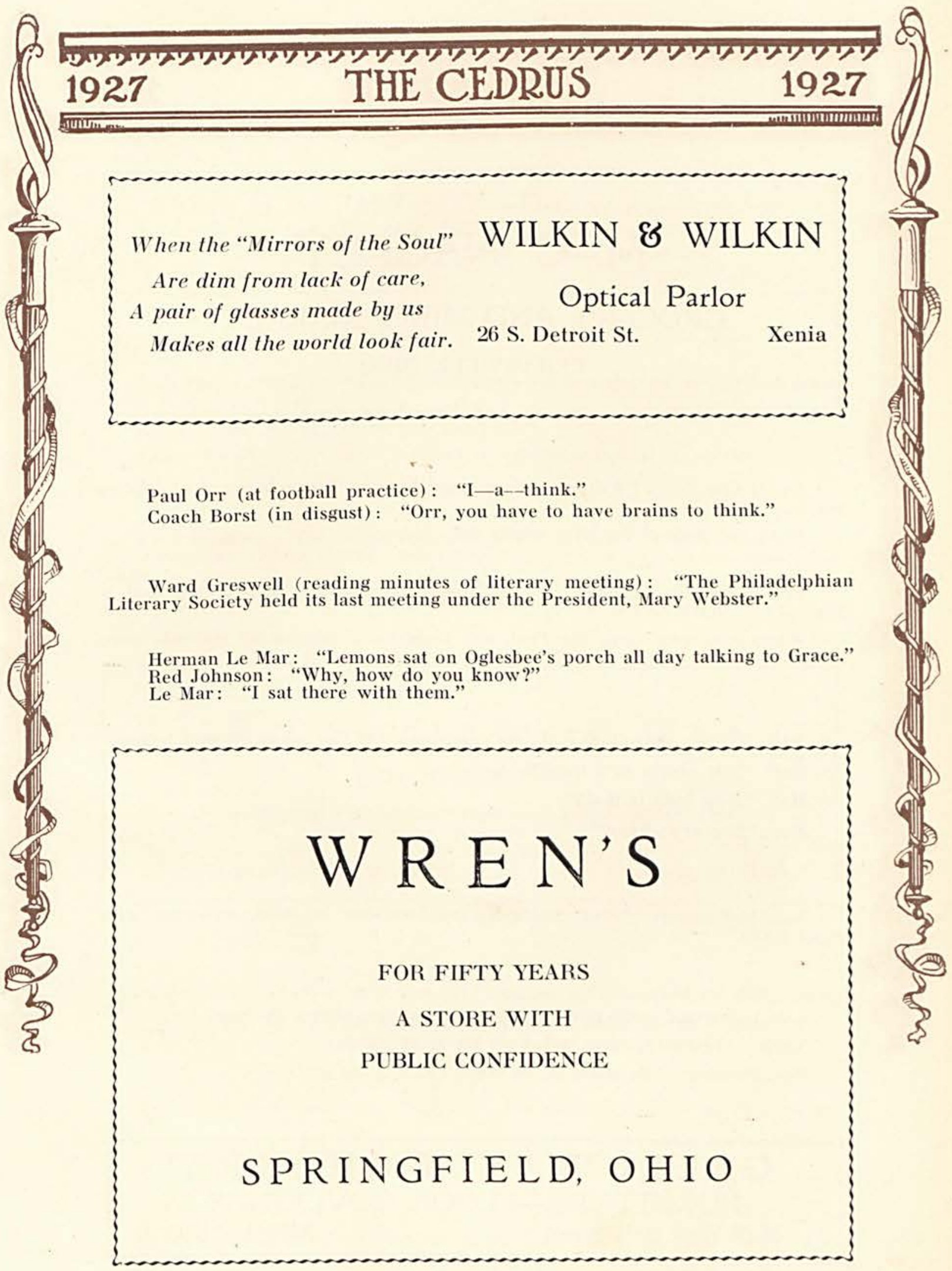



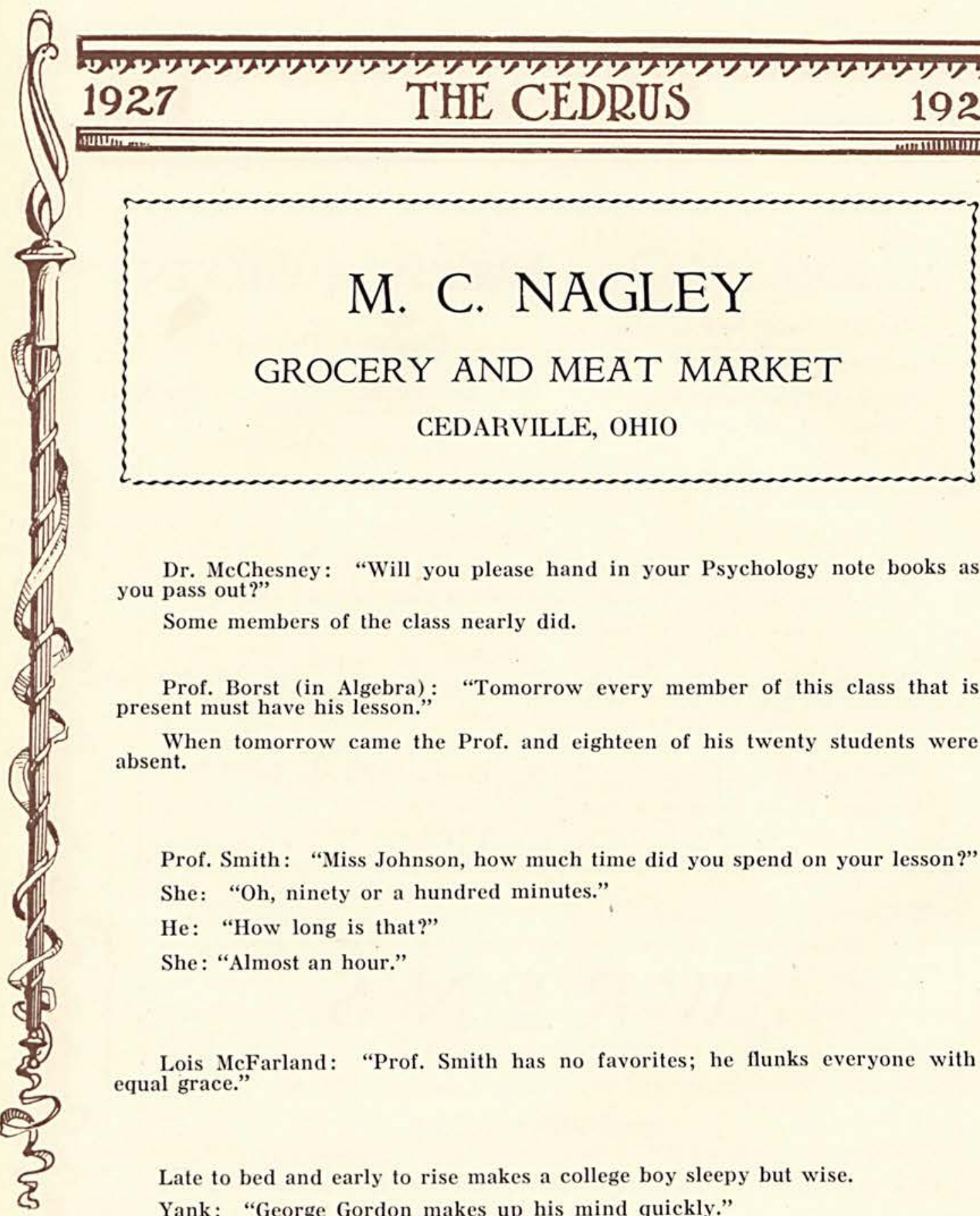

Dr. McChesney: "Will you please hand in your Psychology note books as you pass out?"

Some members of the class nearly did.

Prof. Borst (in Algebra): "Tomorrow every member of this class that is present must have his lesson." absent.

When tomorrow came the Prof. and eighteen of his twenty students were

Prof. Smith: "Miss Johnson, how much time did you spend on your lesson?"

She: "Oh, ninety or a hundred minutes."

He: "How long is that?"

She: "Almost an hour."

Lois McFarland: "Prof. Smith has no favorites; he flunks everyone with equal grace."

Late to bed and early to rise makes a college boy sleepy but wise.

Yank: "George Gordon makes up his mind quickly."

Rev. Fleming: “He ought to; he doesn't have a big job.”

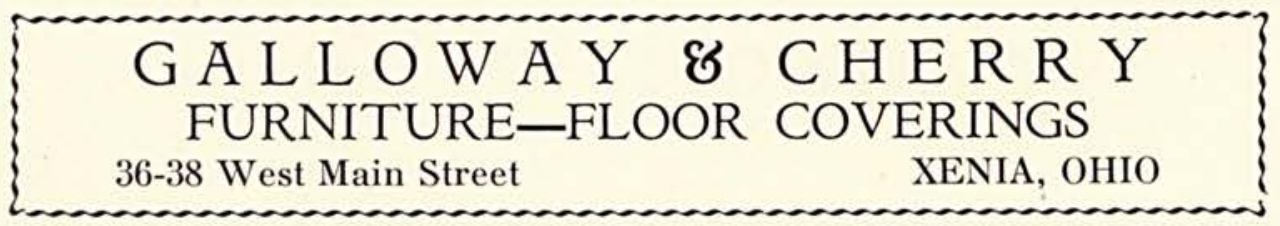




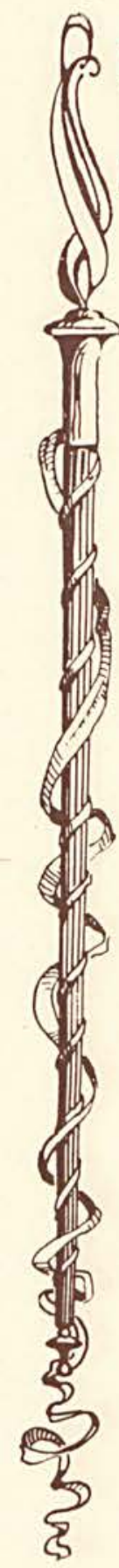

PIERCE \& COMPANY-Decorators, Frescoers

Sherwin-Williams Paints, Stains, Varnishes

Books, Stationery, Window Shades, Draperies

11 South Fountain Avenue Springfield, Ohio

Lois Estle: "Yes, I've read all of Milton's works unless he has written something in the last few days."

Paul Brown: "why, Milton is immortal."

Lois: “Well, I don't care. I didn't see anything bad in his works."

Prof. Frazier: "The industrious and observing student may pick up a great deal during his college course,- especially if he goes on football and basket ball trips."

Deposit Your Savings With

\section{THE EXCHANGE BANK}

\section{CEDARVILLE, OHIO}

$4 \%$ Interest Paid on Savings and Time Certificates of Deposit

Safe Deposit Boxes for Rent

Banking by Mail

"There is plenty of work if you only look for it," remarked Dr. McChesney. Lyon: "Yes, 'tis true, but by the time I've found it my energy is gone." mine."

Mrs. Borst (in Dramatics): "Get upon the stage; I want to see your panto-

Jack Rockhold: “Oh, but I didn't wear them today."

Notice: All of those who haven't heard the story of the ham sandwich or the little dog, see Miss Dolby or Coach Borst at once. 


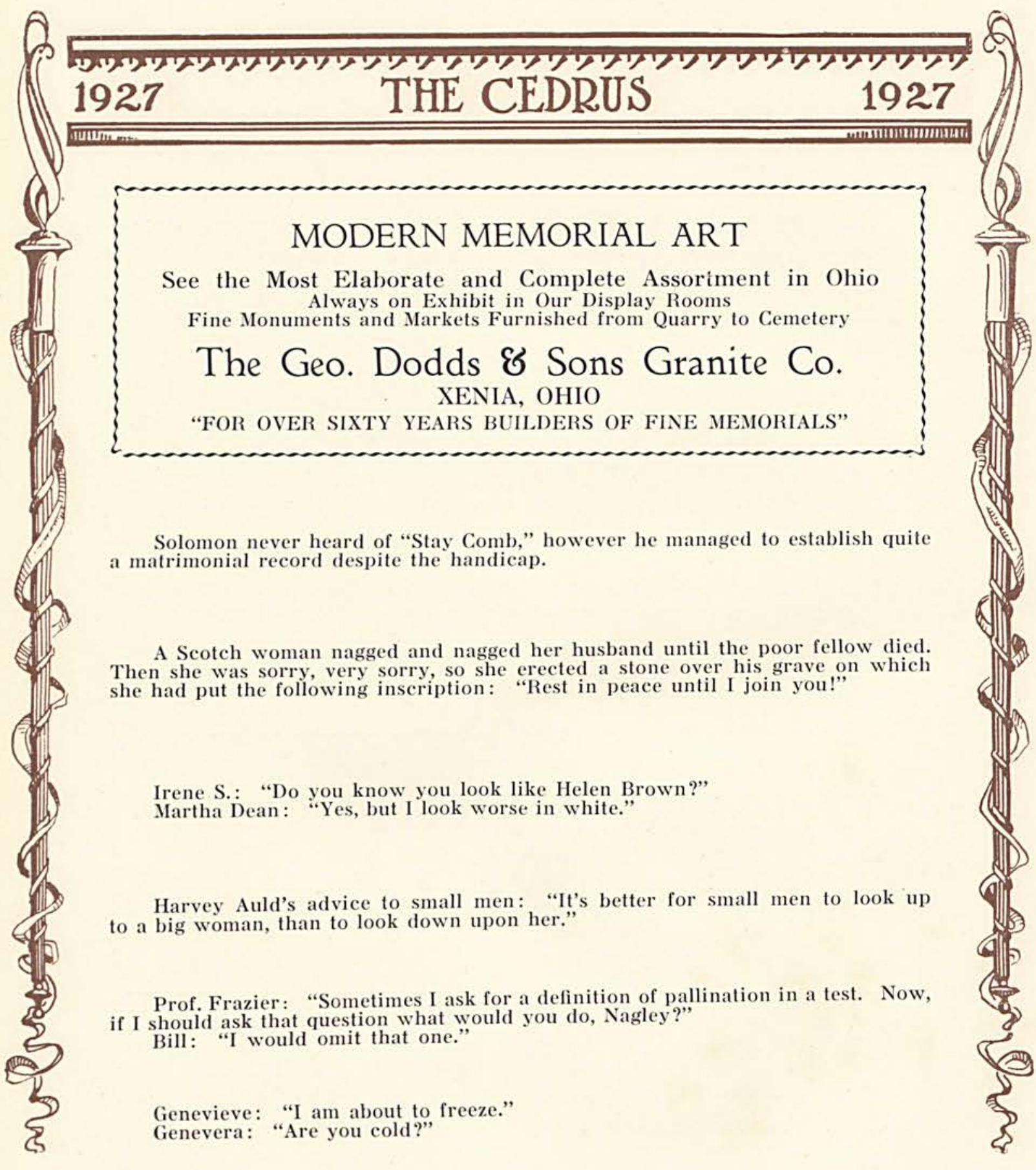

Jean M.: "Mary Ruth you have a new hat."

Mary Ruth: "Oh, thank you."

It was during an uproar of laughter and talking that Prof. Jurkat entered the Chapel. "You people will have to quiet down in here while I am conducting my class across the hall. If you can just remember to lower your voices I can hear more distinctly what each one is saying." 


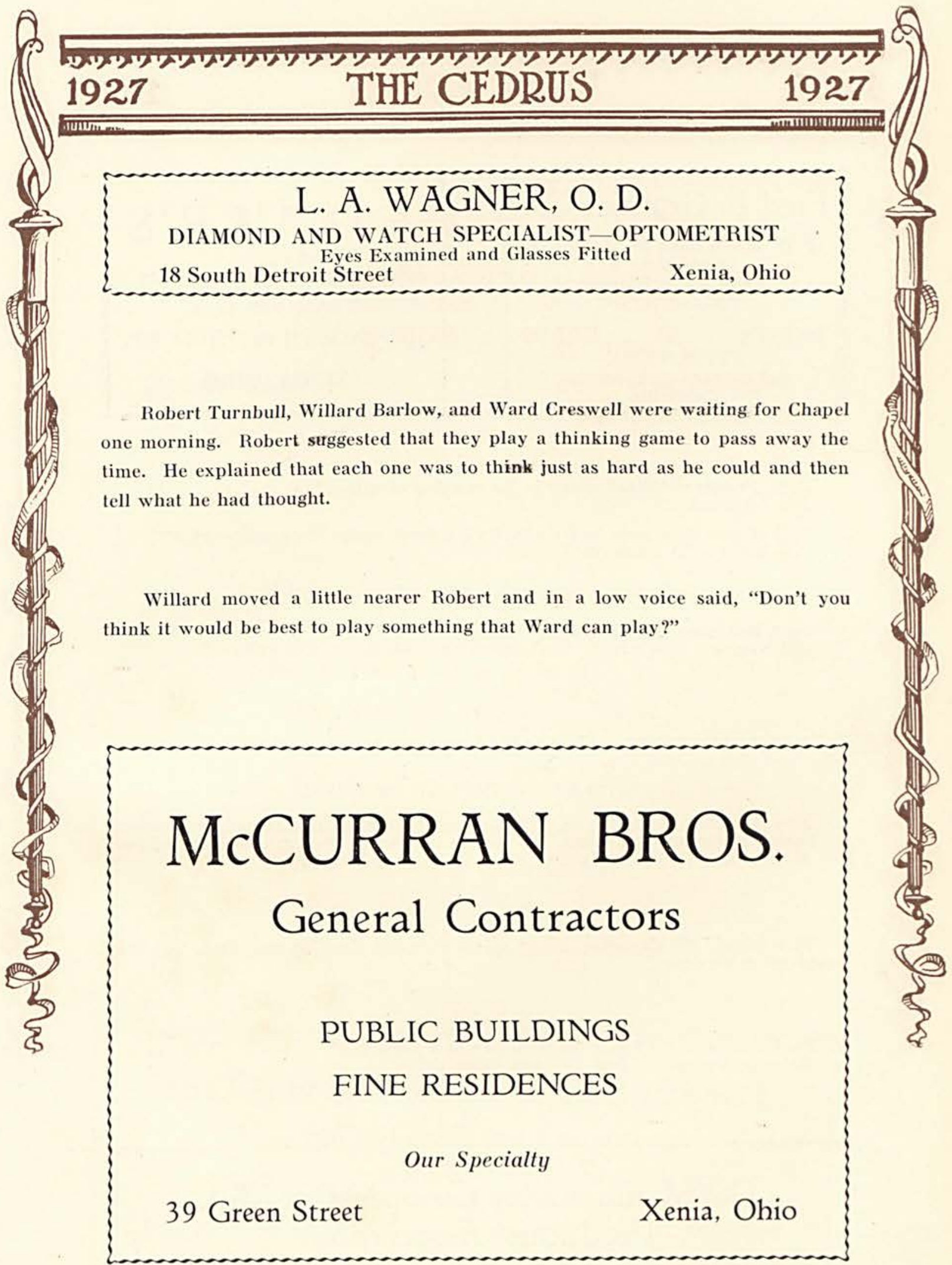




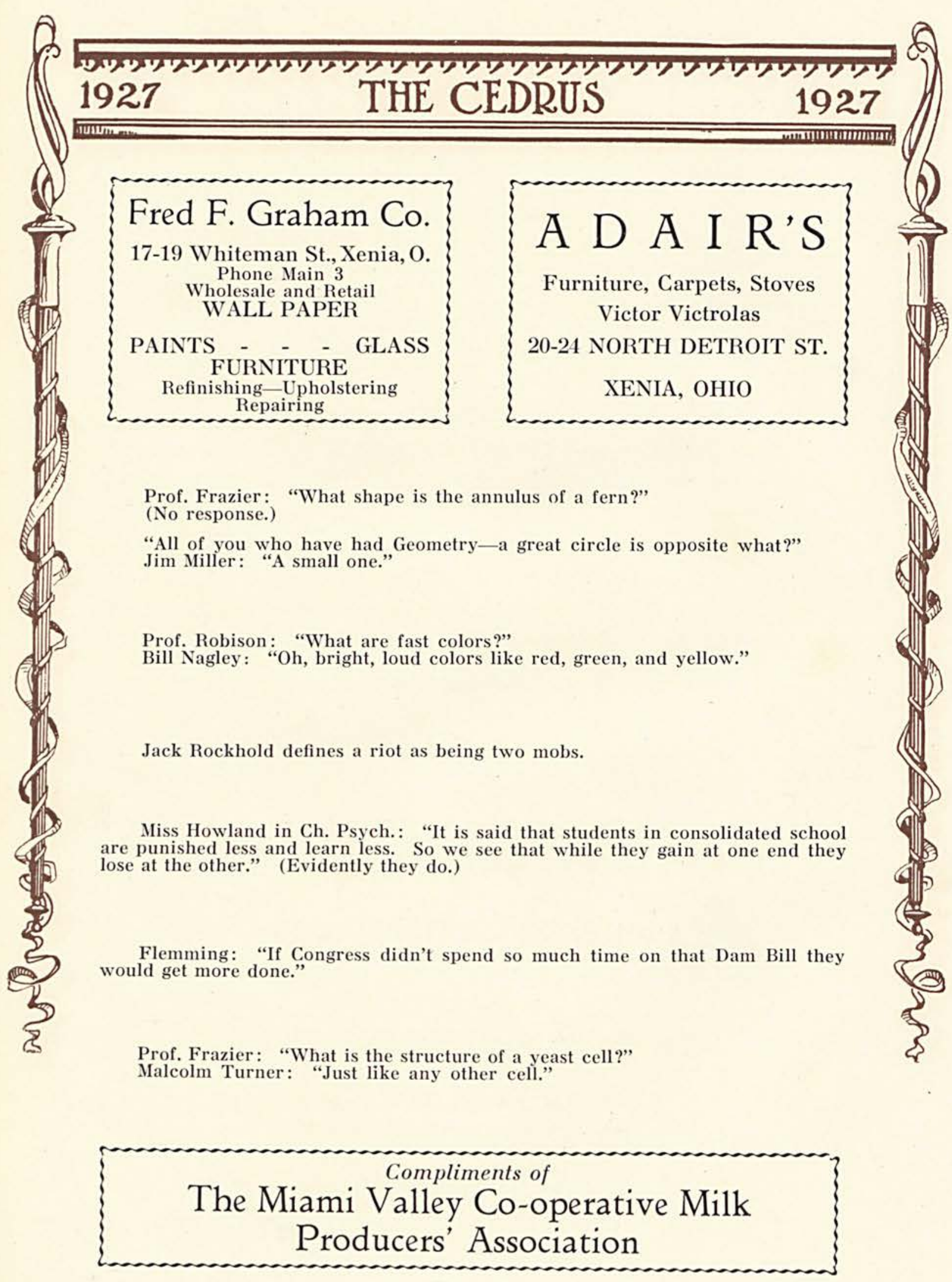




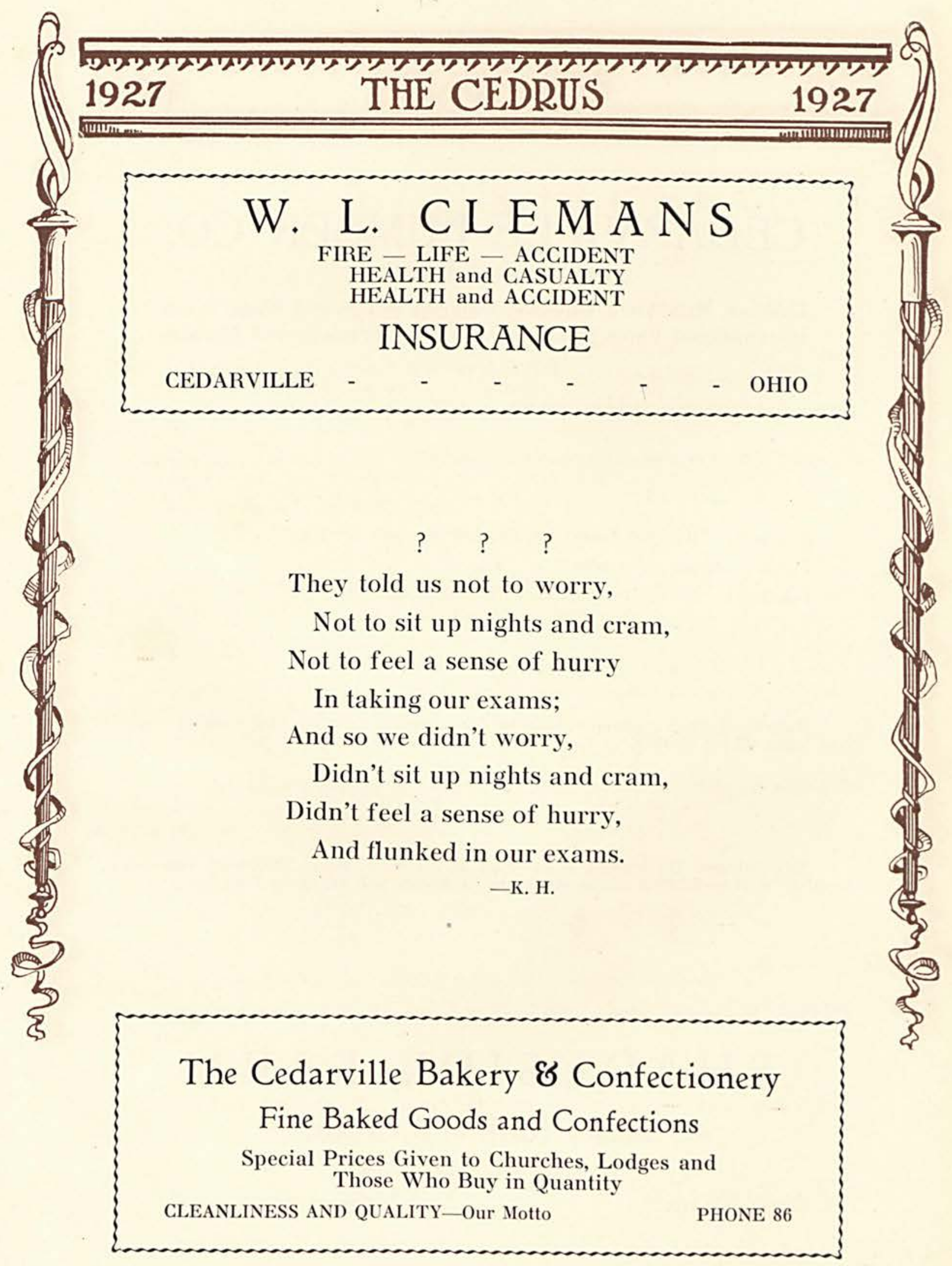




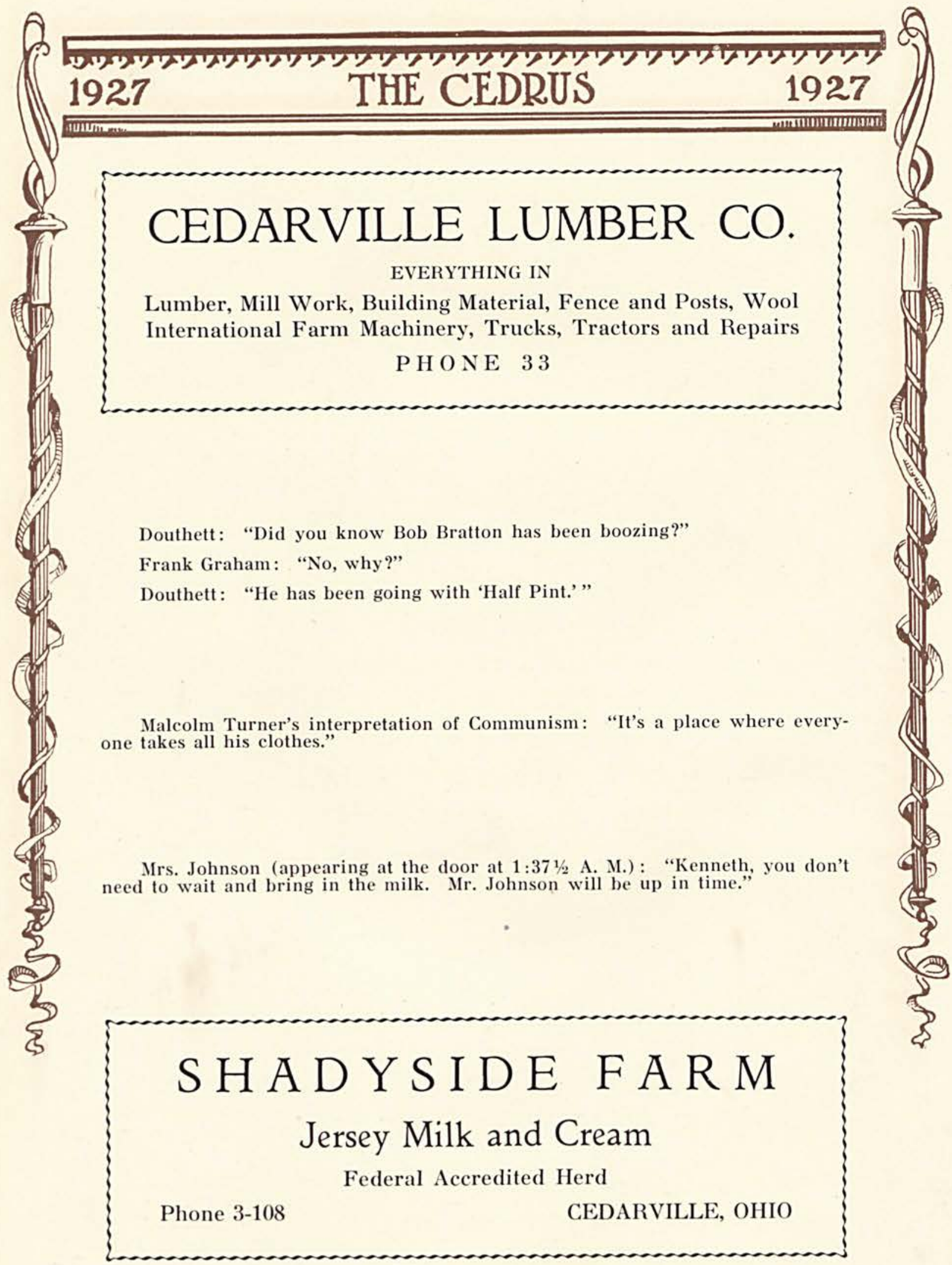




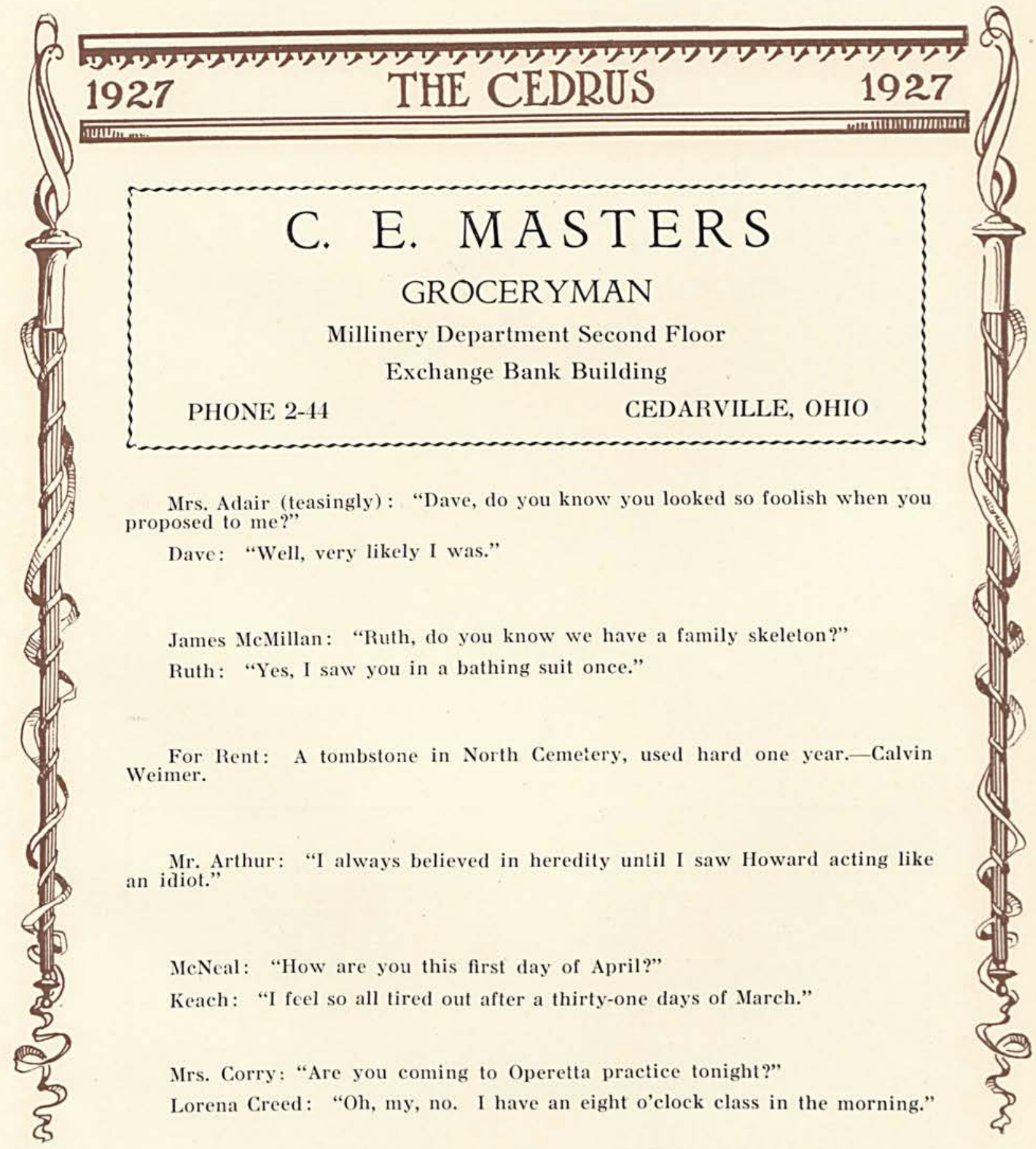

Miss Dolby: "Give an example of a compound sentence, Miss Haydock." like it.’

Haydock (dreamily): "Jasper Graham turned out the lights and I didn't

Prof. Robison: "What kind of a building is the old schoolhouse on Xenia Avenue?"

Bill Barlow: "A deserted one." 


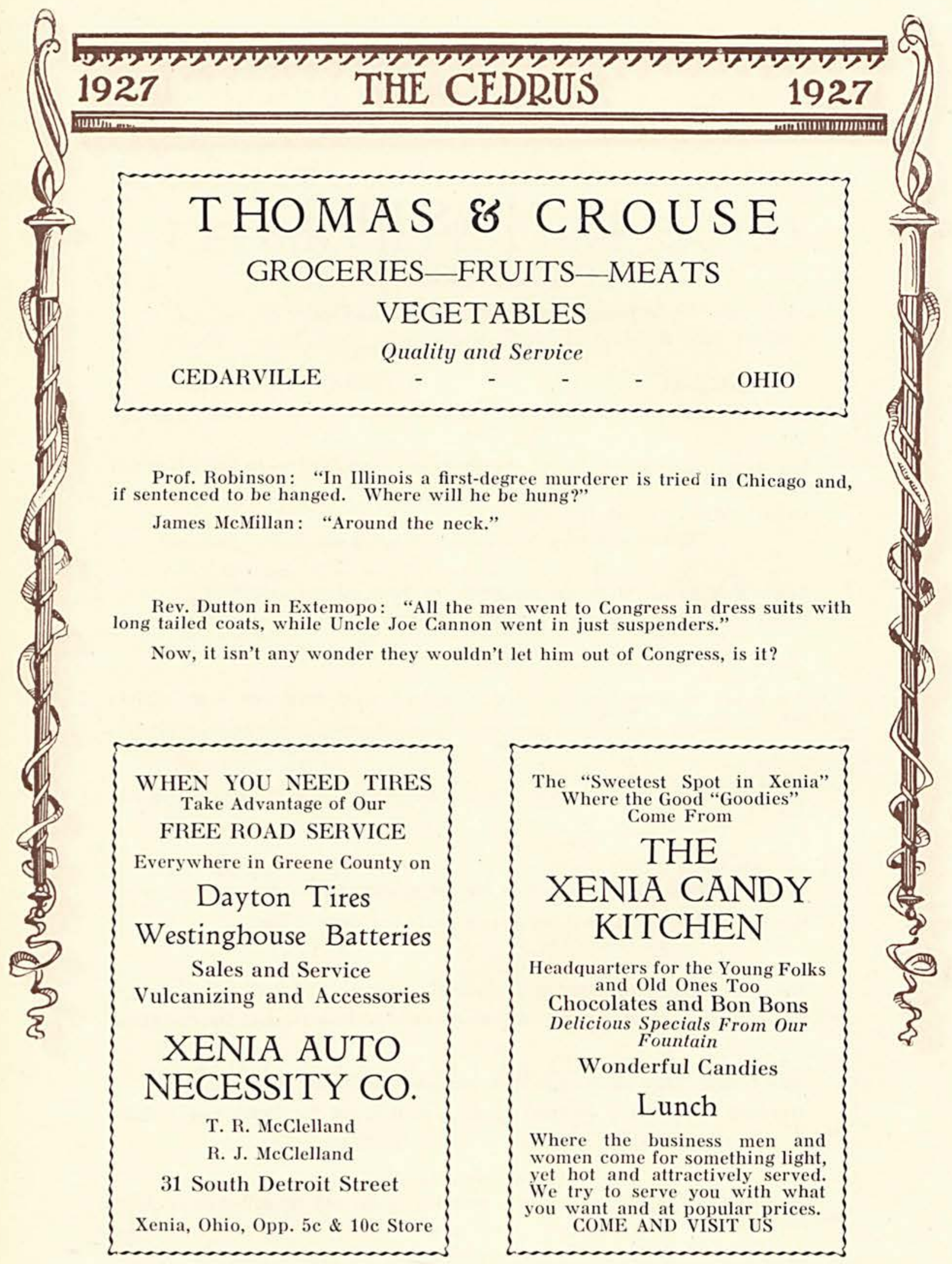




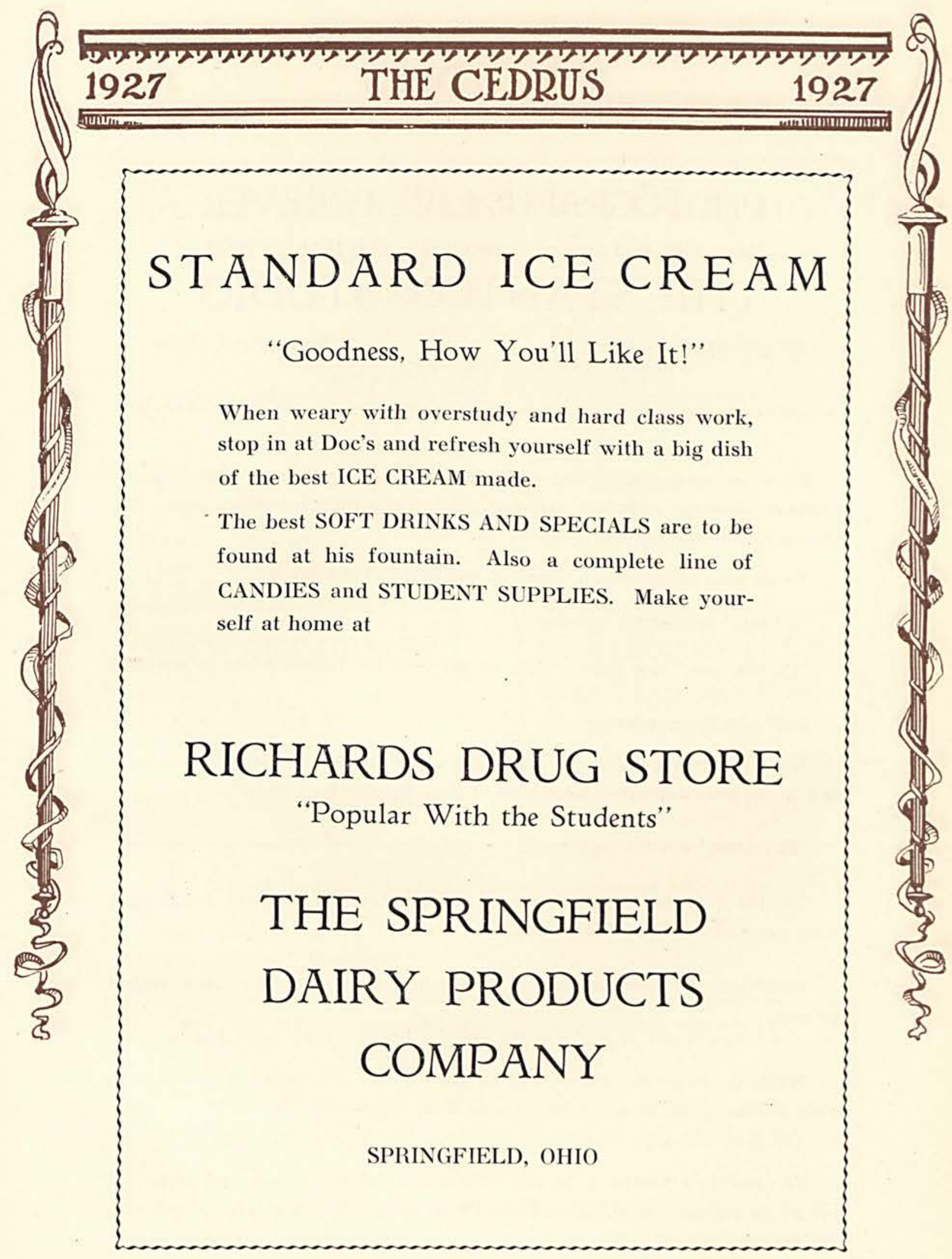




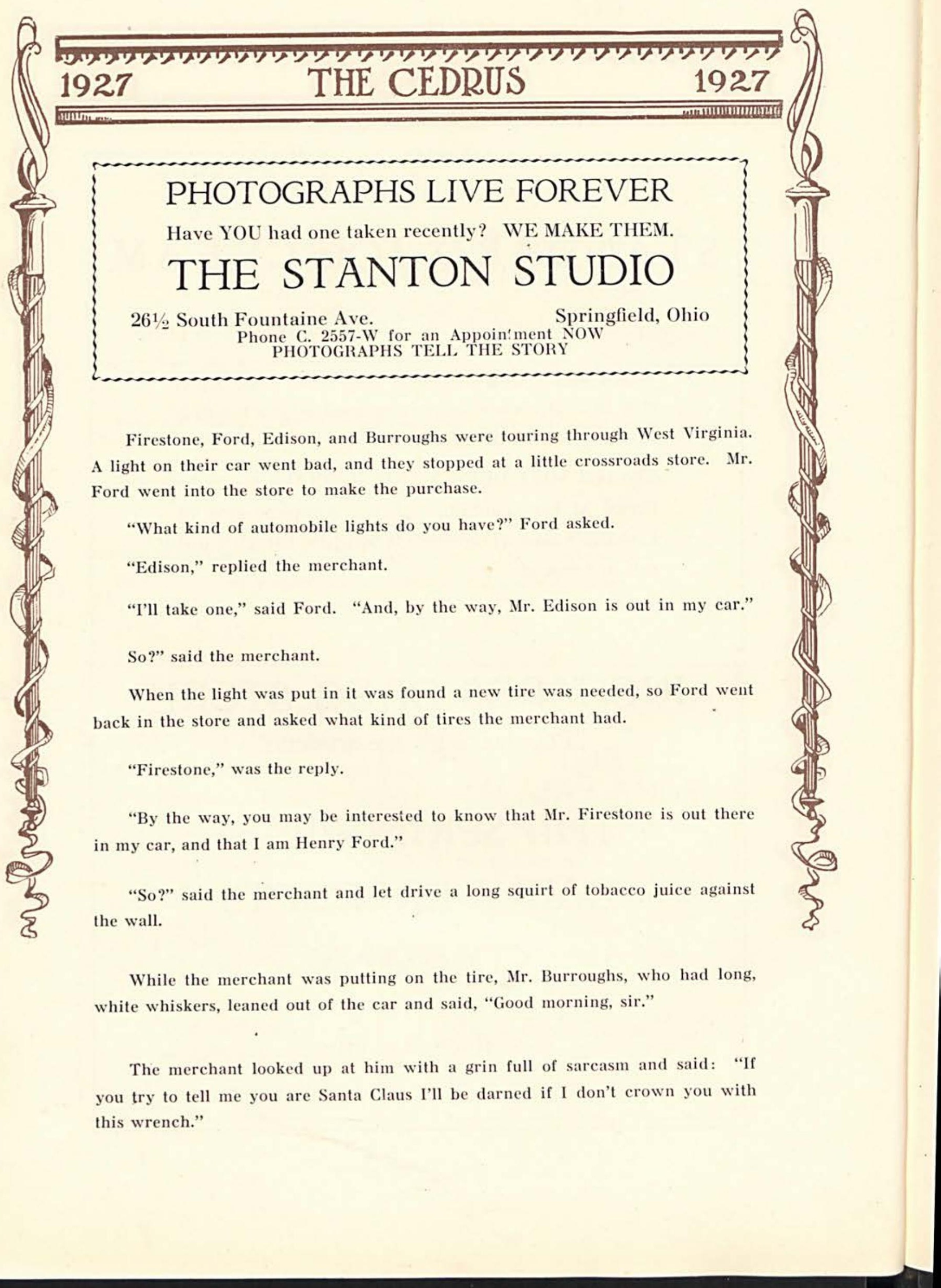




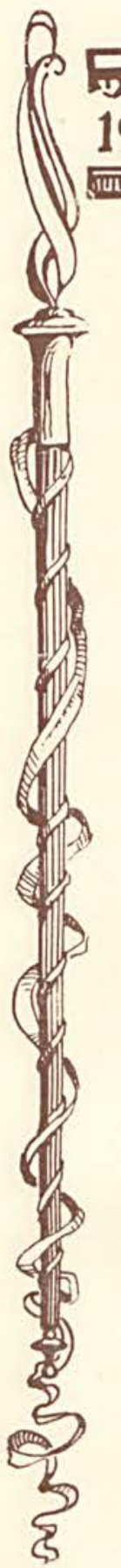

\section{A. E. Huey Hardware Company}

General Hardware, Electric Wiring,

Plumbing, Spouting

General Repair Work a Specialty

PHONE 2-128

Prof. Frazier: "What kind of a filament is in a light bulb?"

Doc Evans: "I don't know?"

Prof.: "Why not?"

Doc: "All of Dobbins' bulbs are frosted."

\section{LEO ANDERSON \\ D. V. M. \\ Veterinarian \\ CEDARVILLE - - OHIO}

Miss Lieving (in French Class): "Monsieur Armstrong, what is the past participle of avoir?"

Armstrong (as usual): "Eu-"

Miss Lieving: "Correct."

\section{ROBERT BIRD \& SONS COMPANY}

\section{CEDARVILLE, OHIO}

"Always the Best at Lowest Possible Prices"

What the College Student Wants or Needs Is Our Specialty

"Buy at Bird's and Buy the Best" 


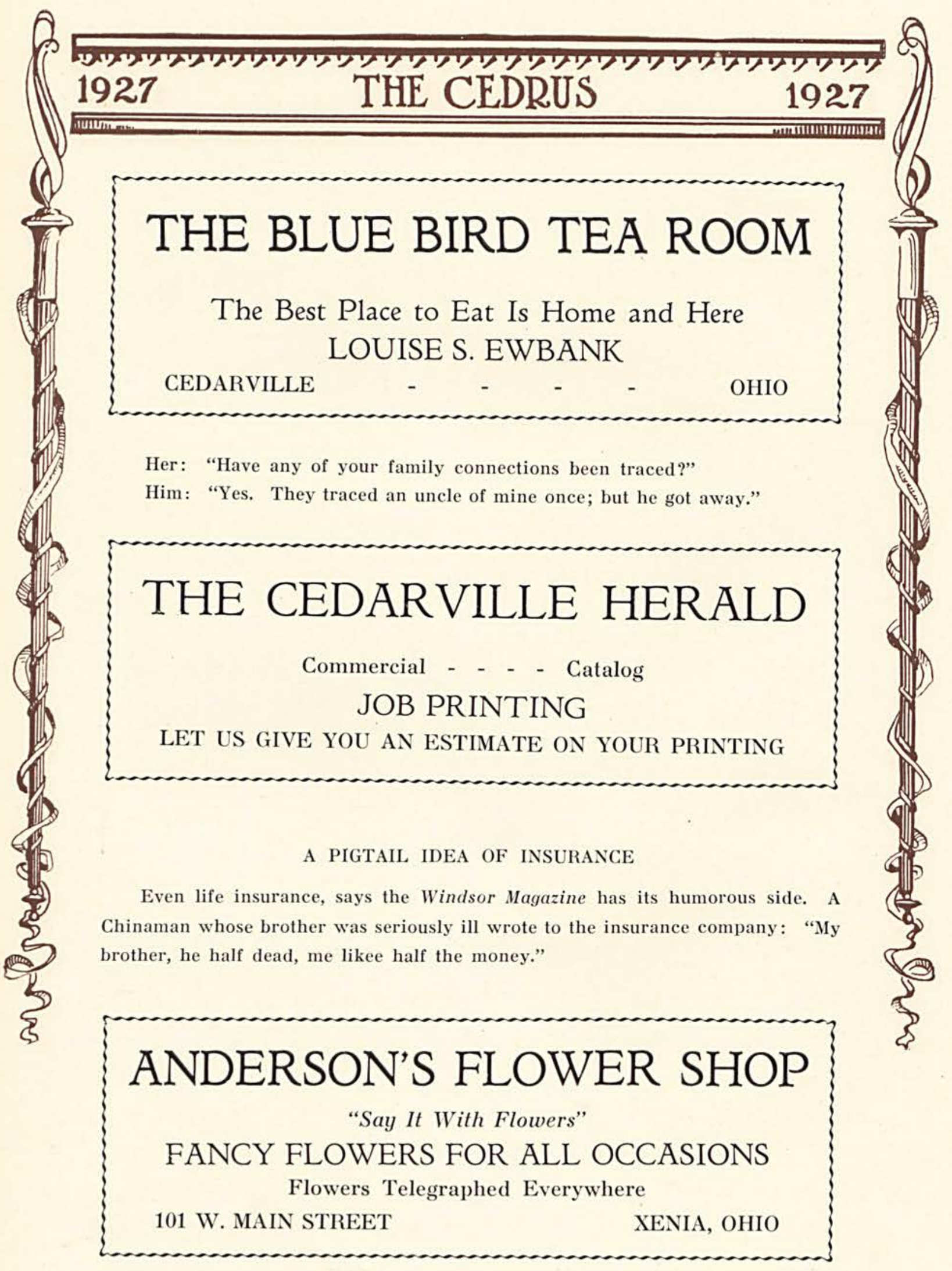




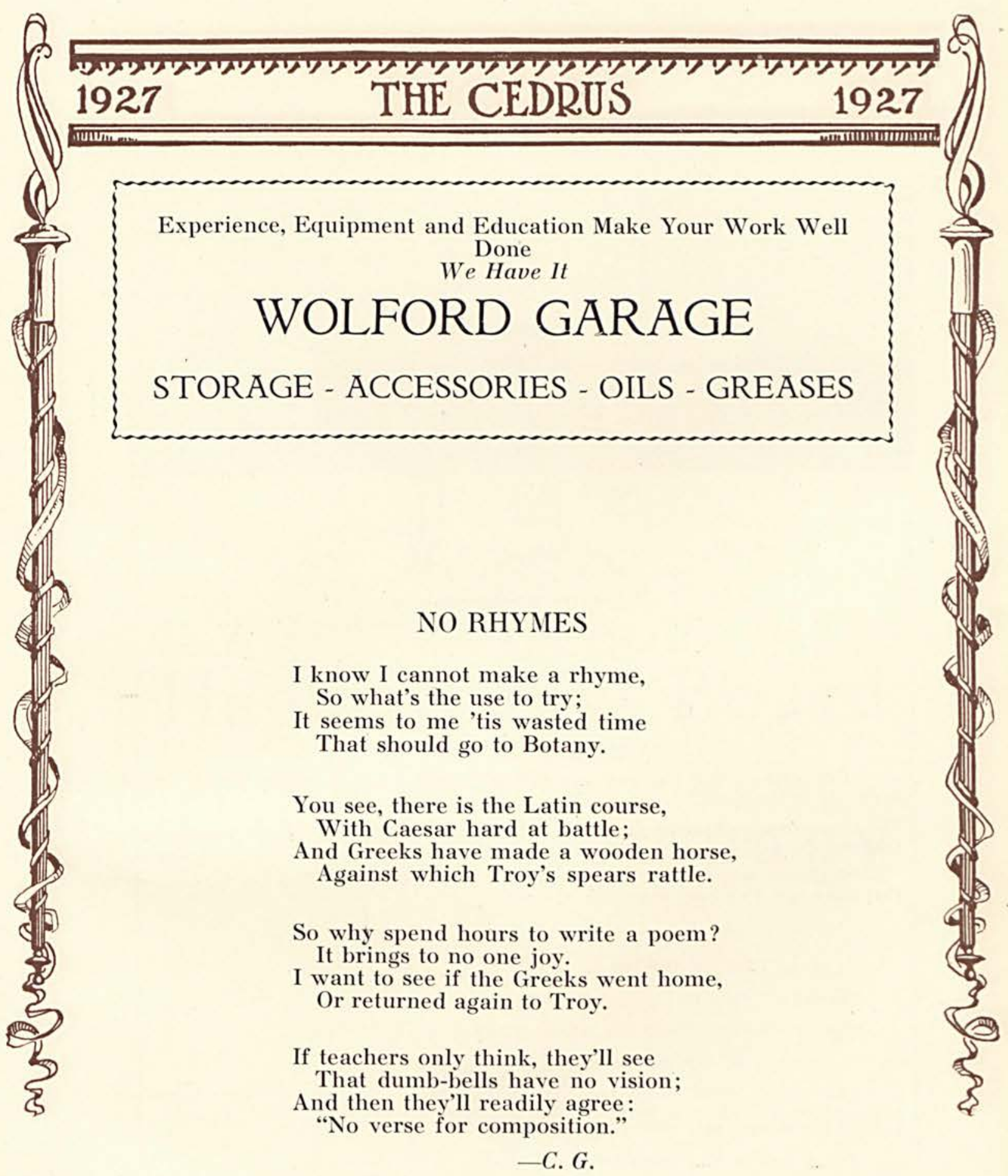




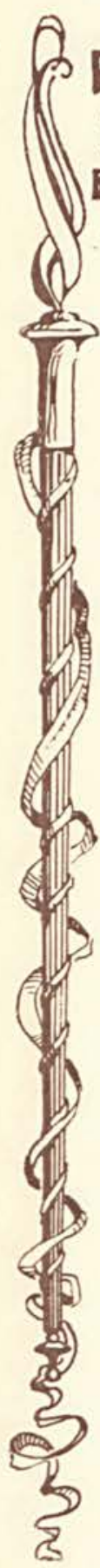

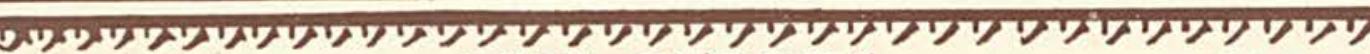
1927 THE CEDRUS

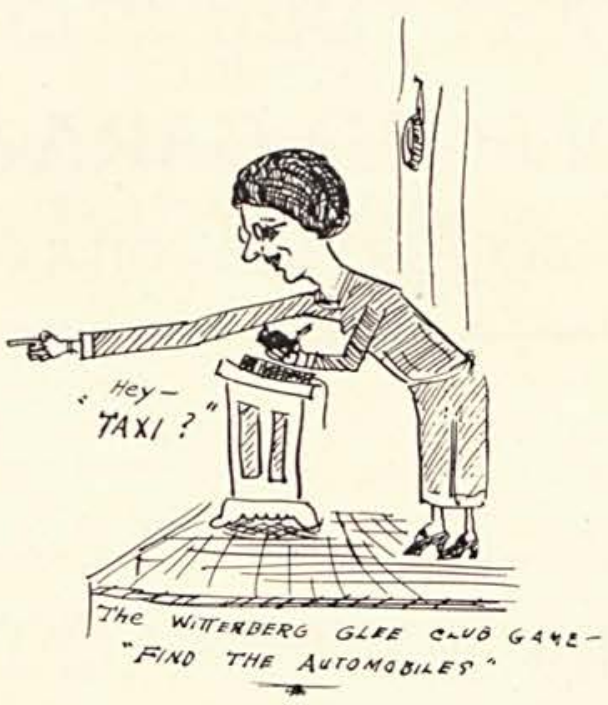

THE QUICK-WITTED CELT

"One seat on the top and one inside," shouted a bus conductor as his car drew up at the curb."

"Sure now and you wouldn't be after separatin' a daughter from her mother," said the elder of two women on the sidewalk.

"Right ye are, I would not," replied the conductor, starting the bus. "I did that once, an' I've been regrettin' it ever since."

He-sez: "I'm just itching to write."

She-sez: "Take this piece of paper and scratch a bit."

"You refuse me?" said the ardent youth.

"I do, indeed," replied the beautiful girl.

"Ah, then I shall go off to the war in Mexico. Suppose I return minus an arm, minus an ear, and minus a chin? Suppose I return a mere remnant of a man, what would you say?"

The beautiful girl brightened.

"I should accept you on the spot. I always had an irresistible fascination for remnants."

A little girl, finishing her breakfast hash, looked up quaintly. "Mother," she asked, "what is hash when it's alive?" 


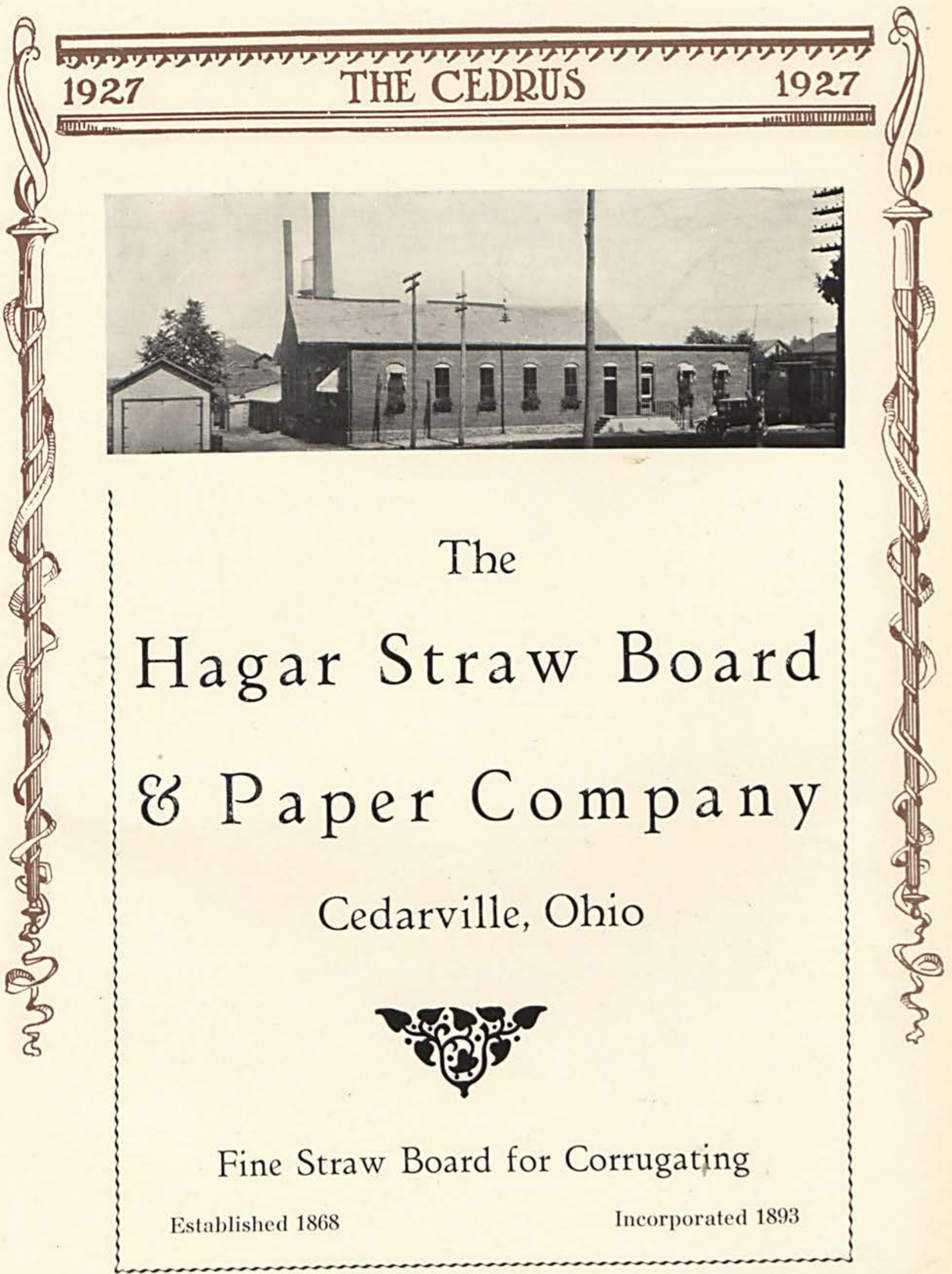




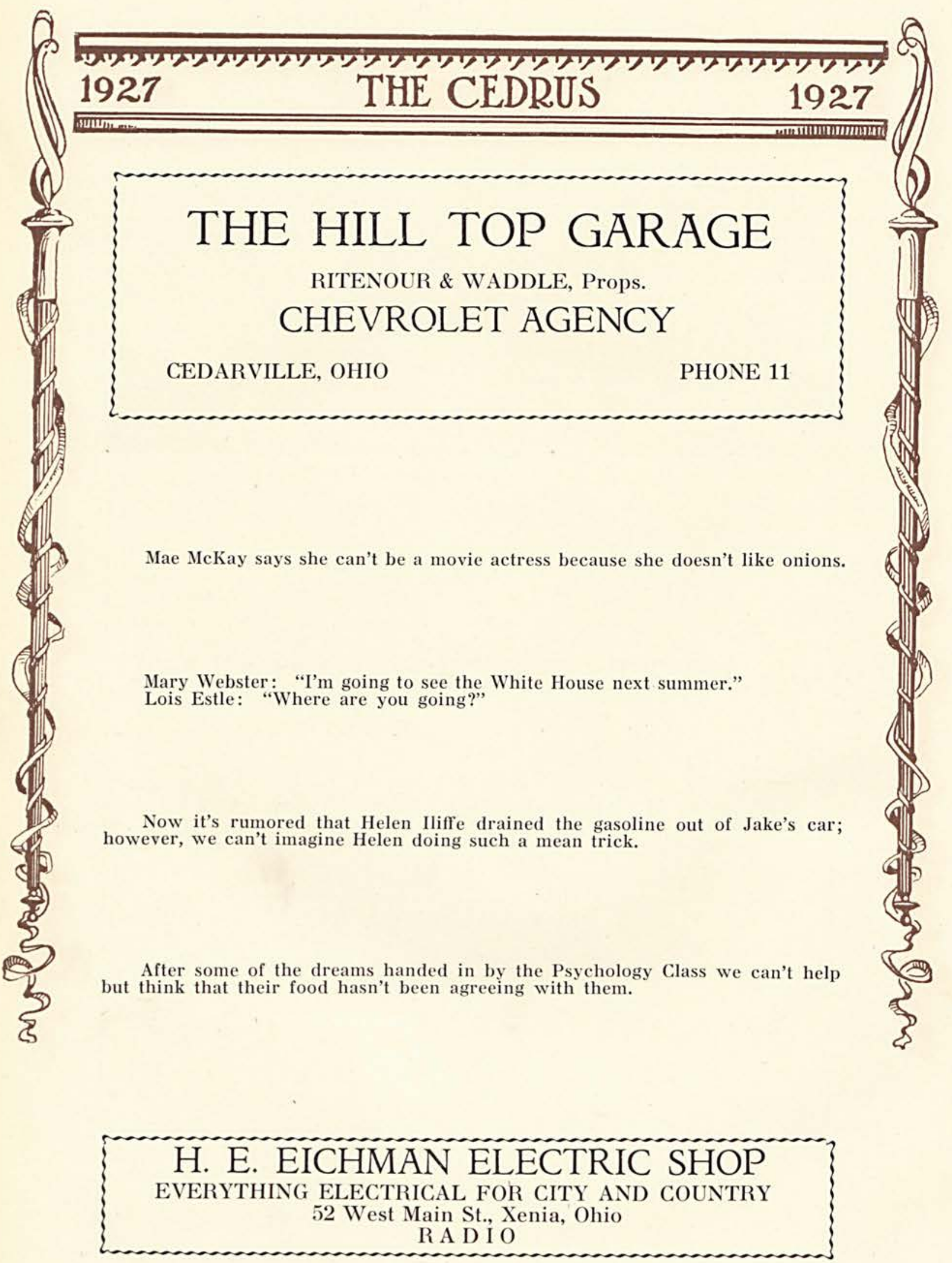




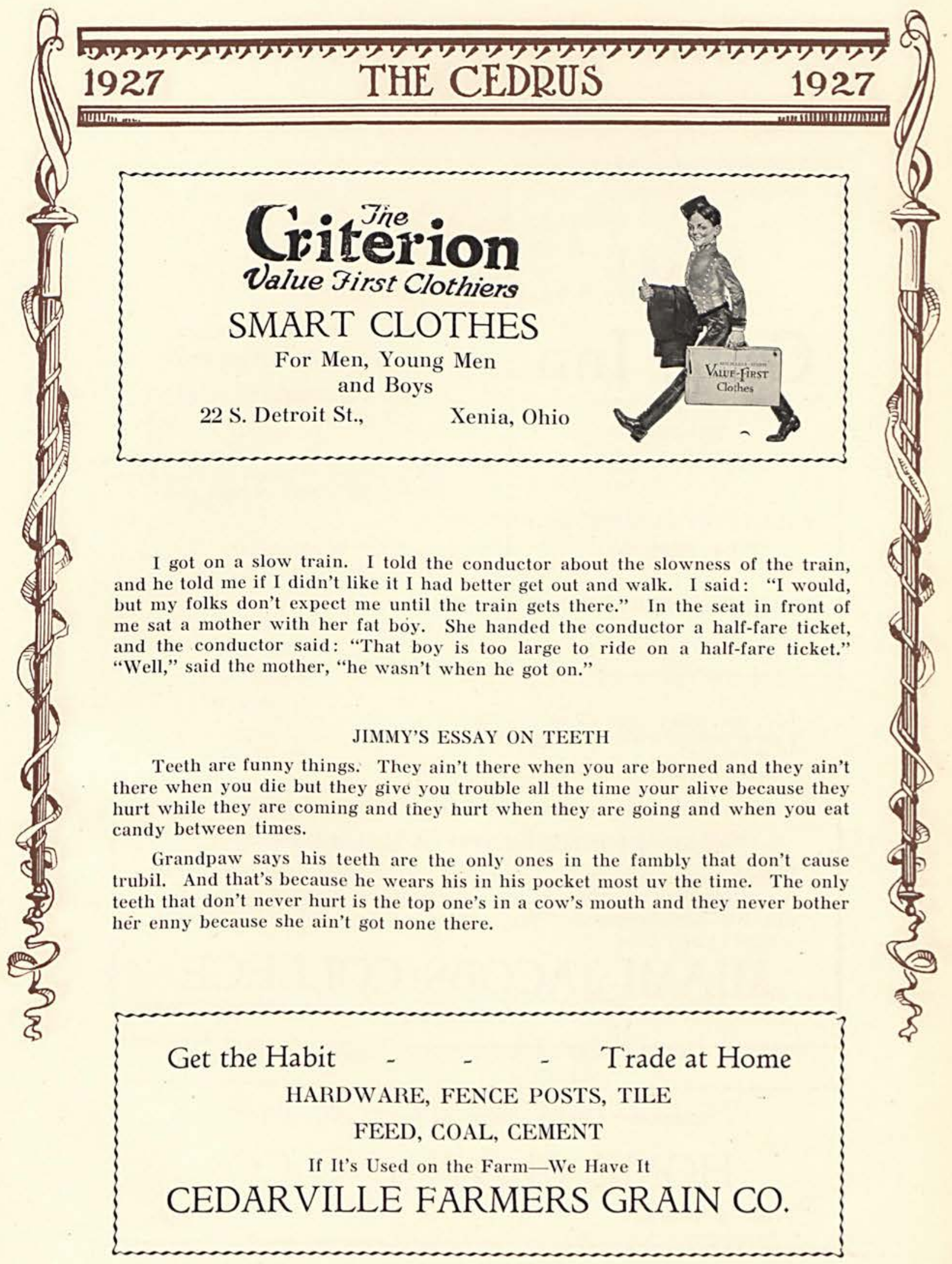




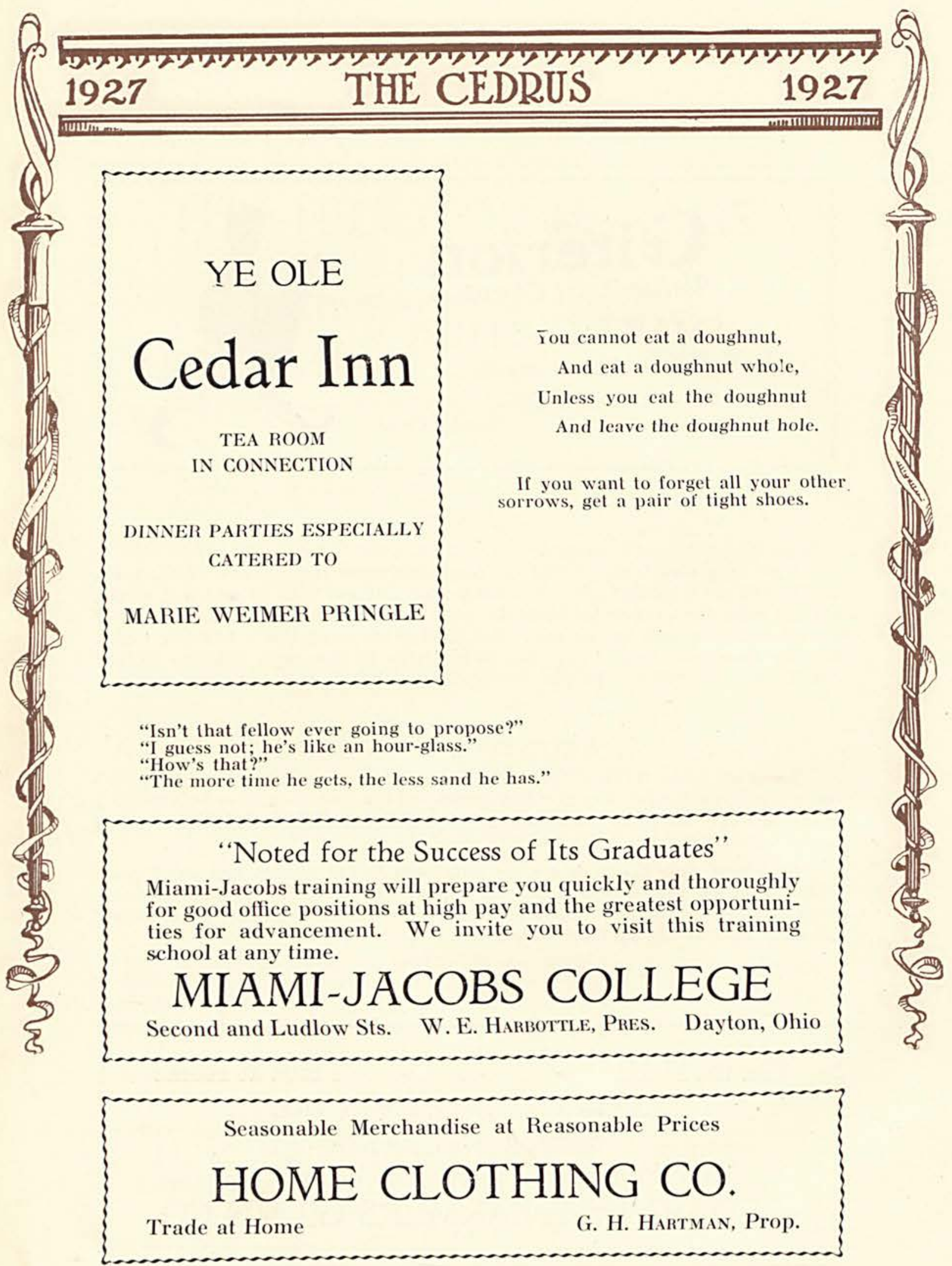


Pocket Billiards Smokers Supplies

\section{McCORKELL'S}

FRATERNITY HOUSE Super-Confectionery

Good Environment

"A Trysting Place for Good Fellows"

Quick Service

\section{COLLEGE FAIRY TALES \\ By Grime}

Once there was a boy who went to college, made fraternities, girls, parties, and grades.

Once there was a little girl who went to college on an allowance, and stayed within it.

Once a college boy took a blind date-and she was good-looking and not a lemon, and he wasn't sorry he went.

Once a boy kissed a college girl the first night out, and she slapped him.

Once a college boy did what he set out to do, and didn't do the things he'd been told not to do.

Once there was a college girl, who studied nights, and was popular.

Once upon a time there was a college boy, and he asked, "Are you hungry?" And she answered, "No."

\section{Tickle Your Appetites With Good Eats Troute's Cash and Carry Grocery}




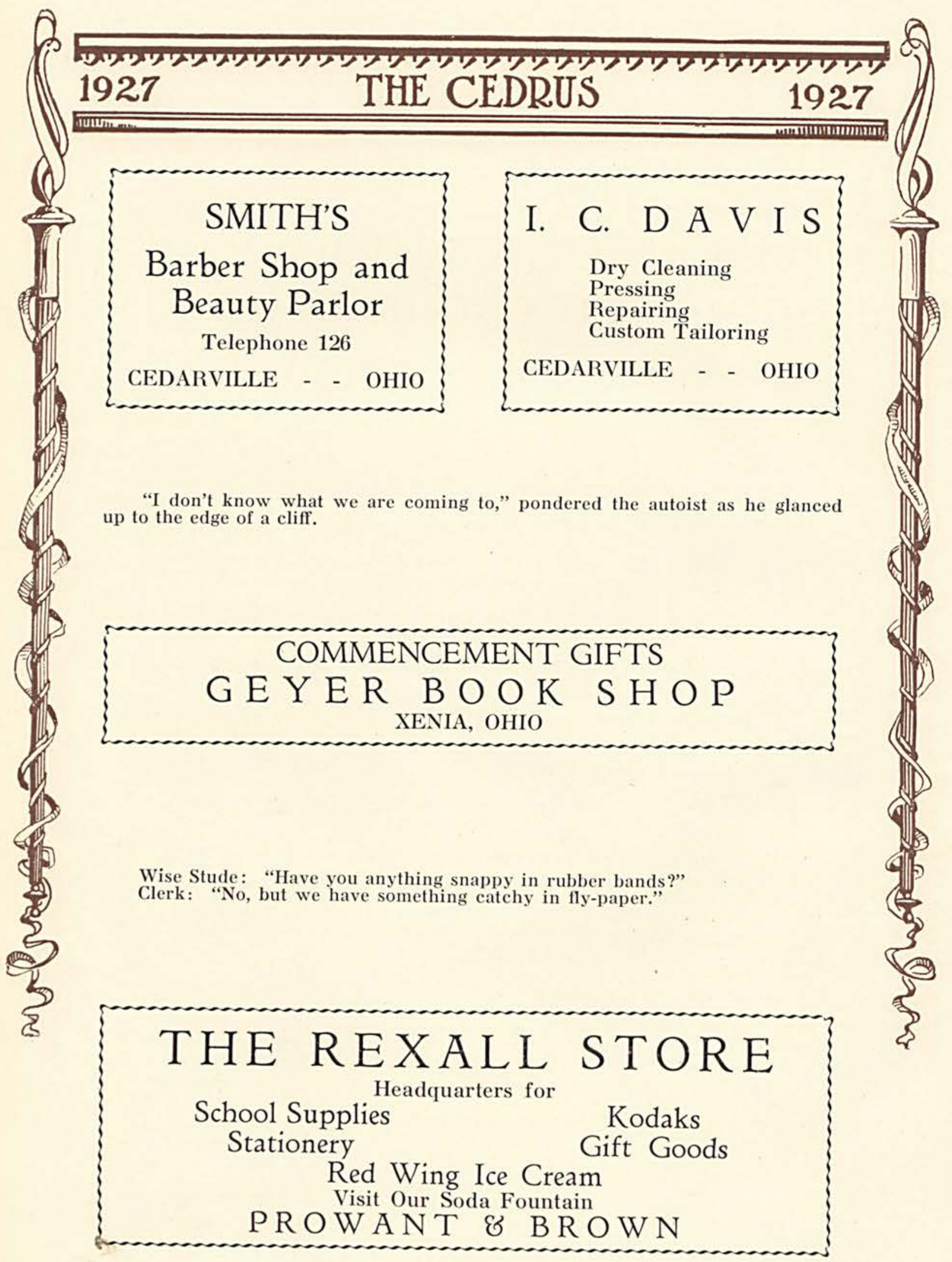




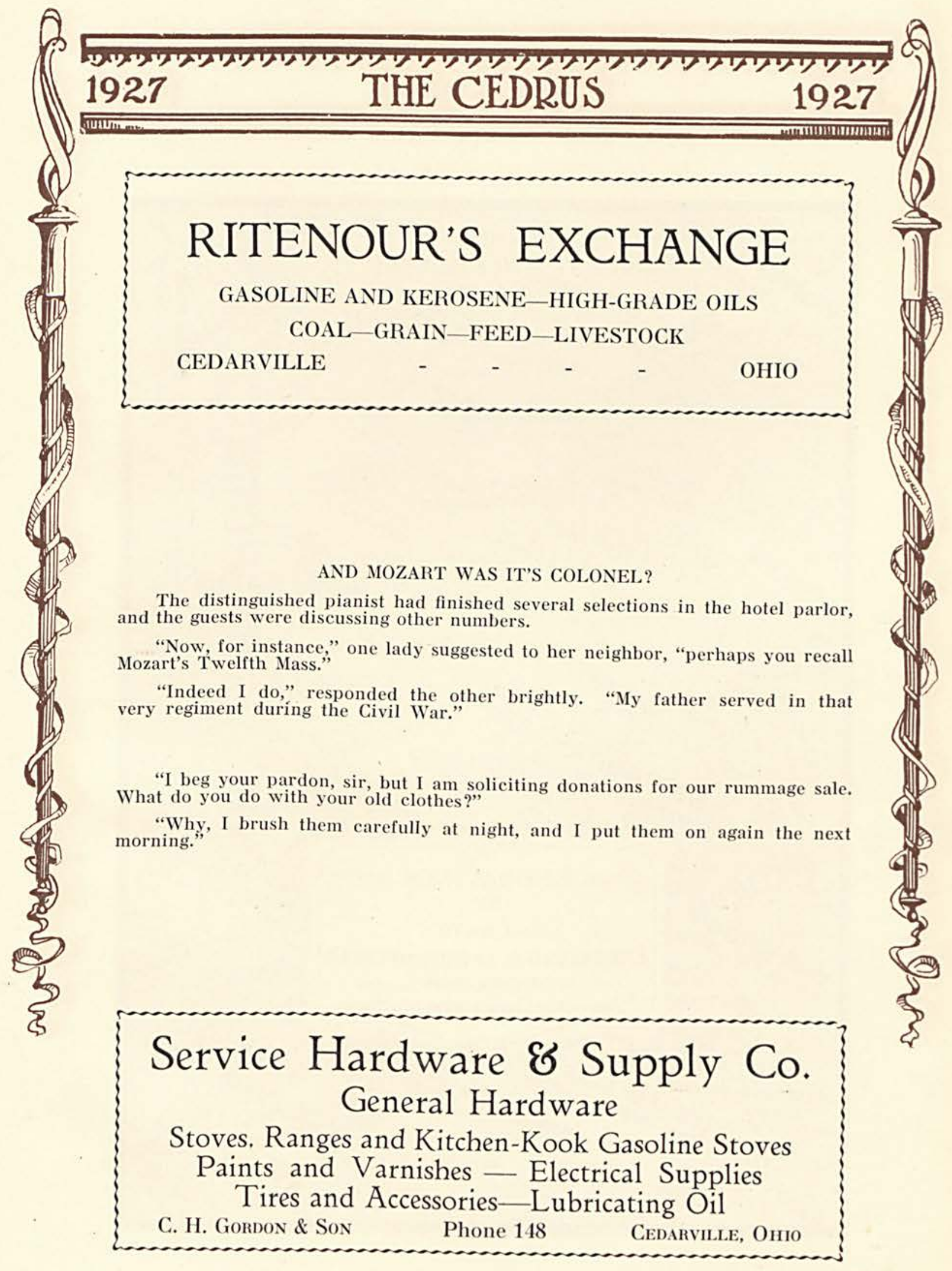




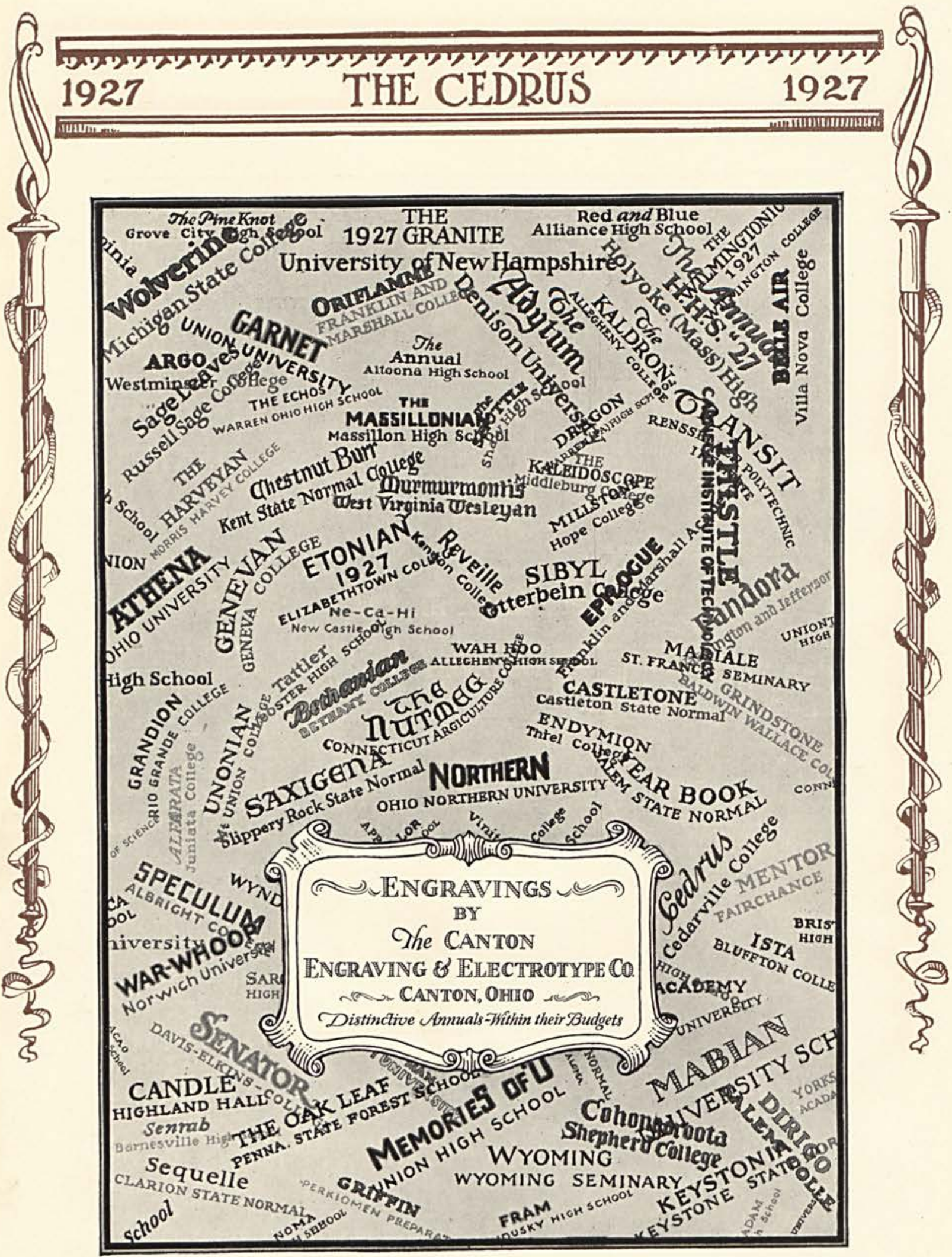




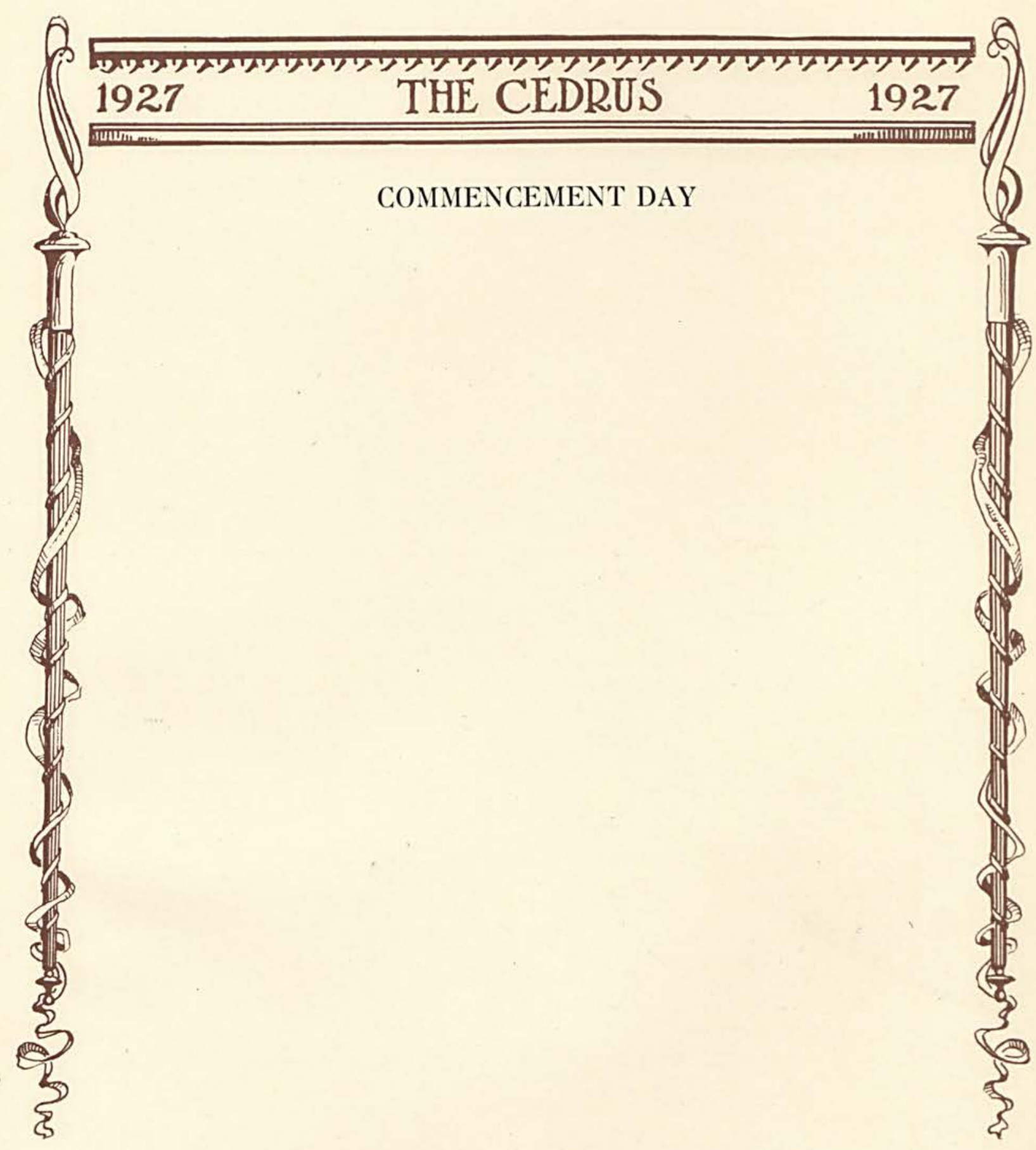




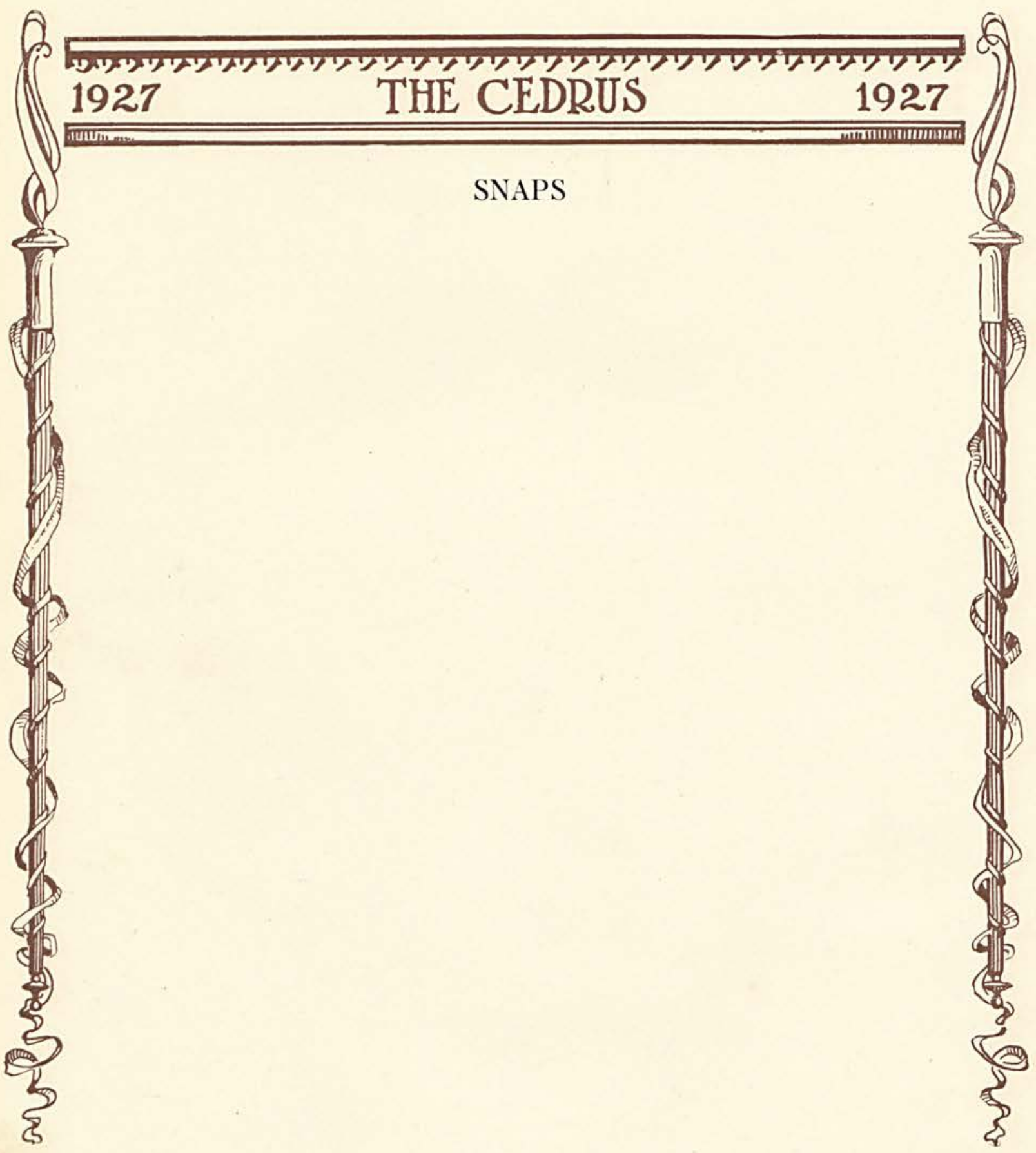




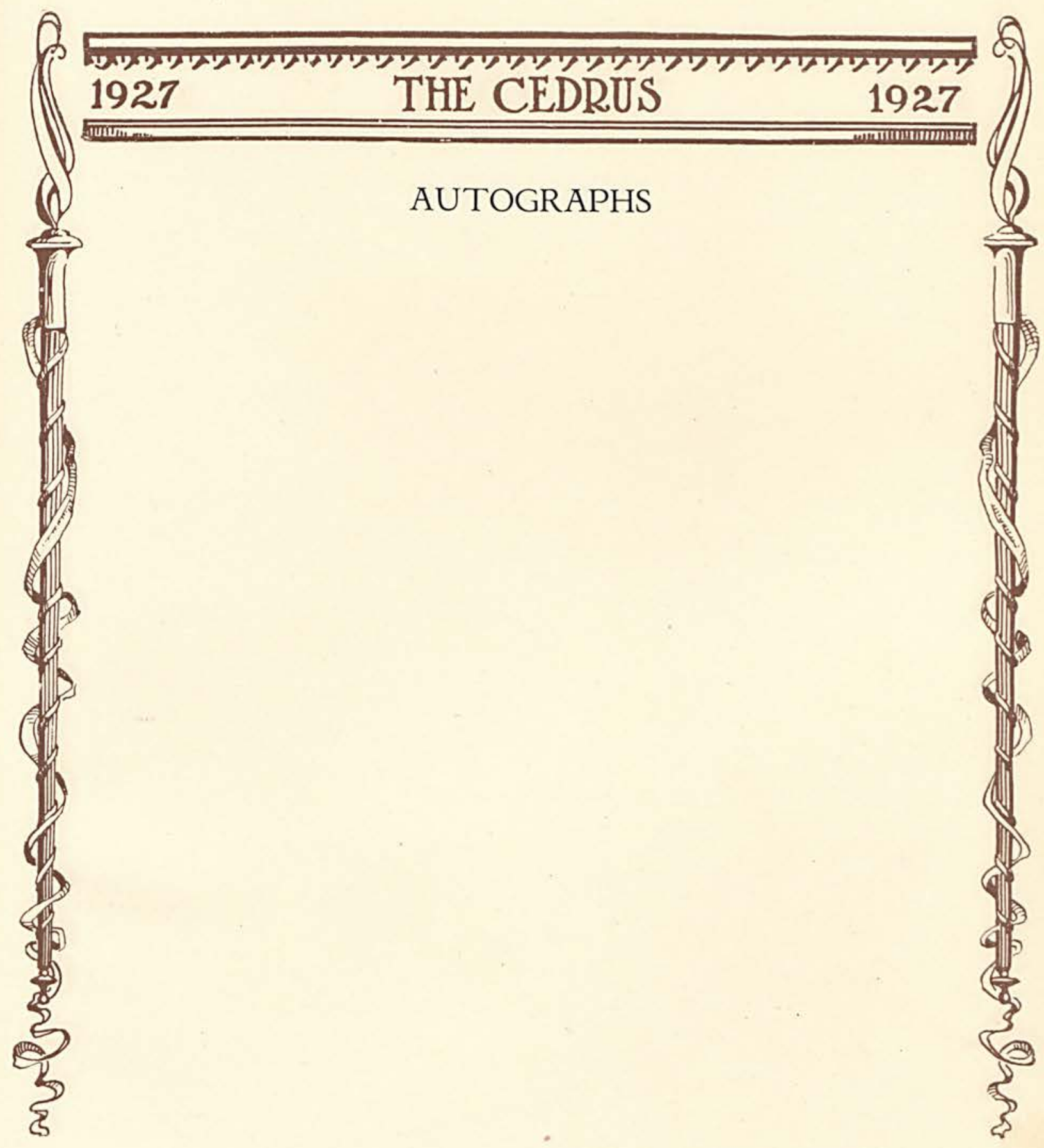


Q

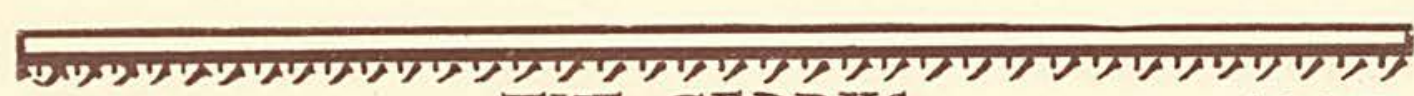
1927

THE CEDRUS 1927

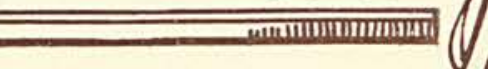

\section{AUTOGRAPHS}




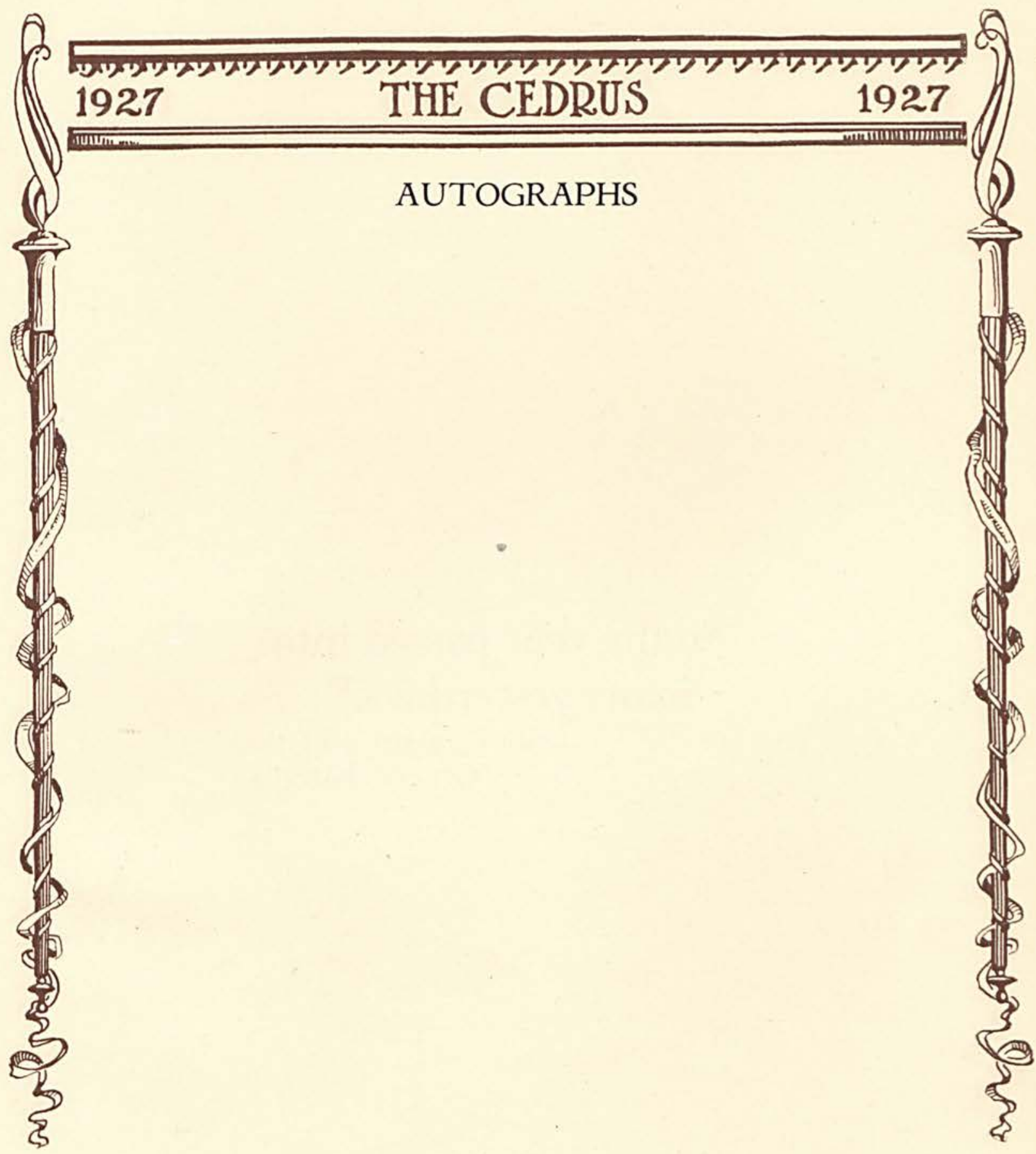




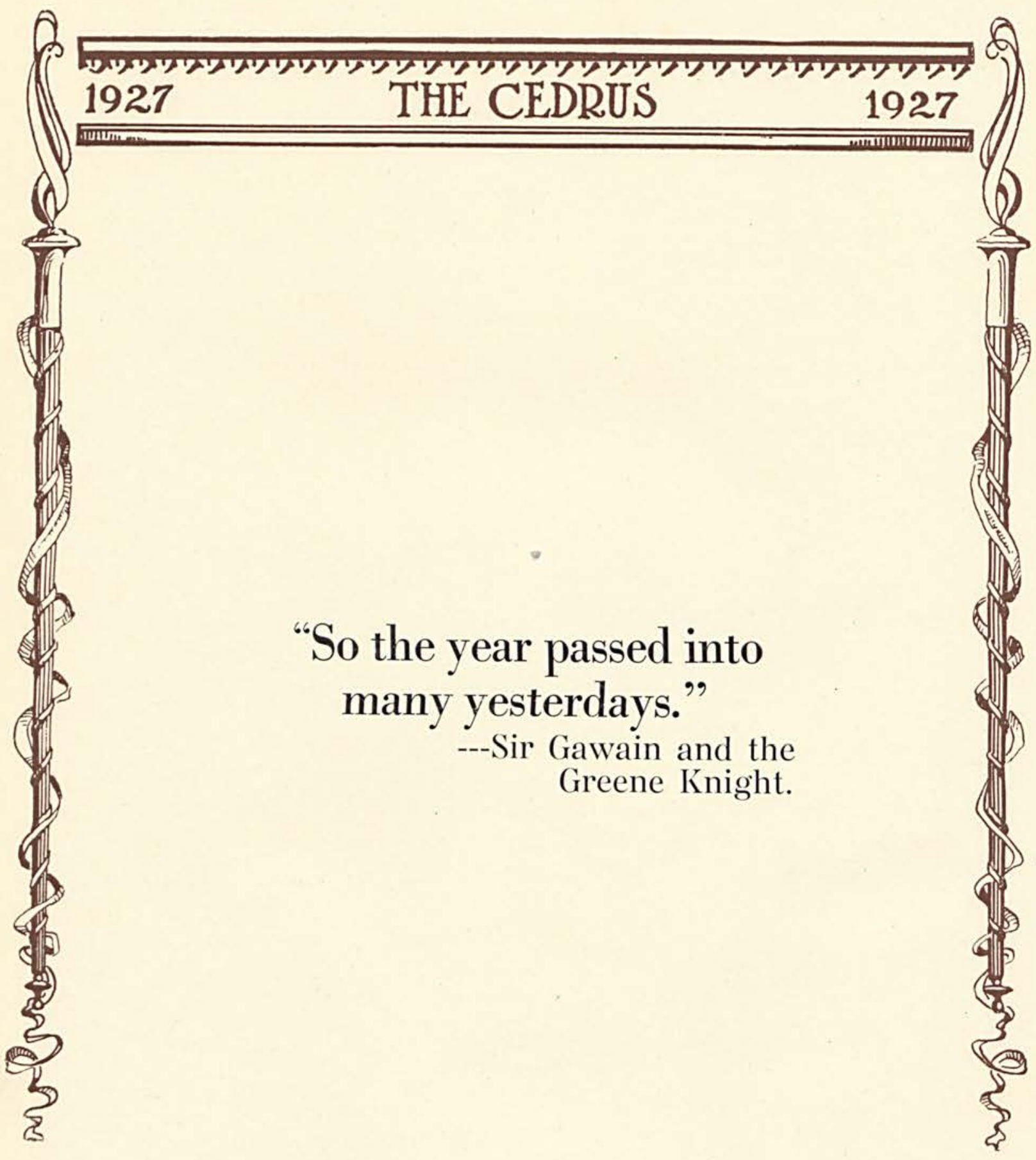




